
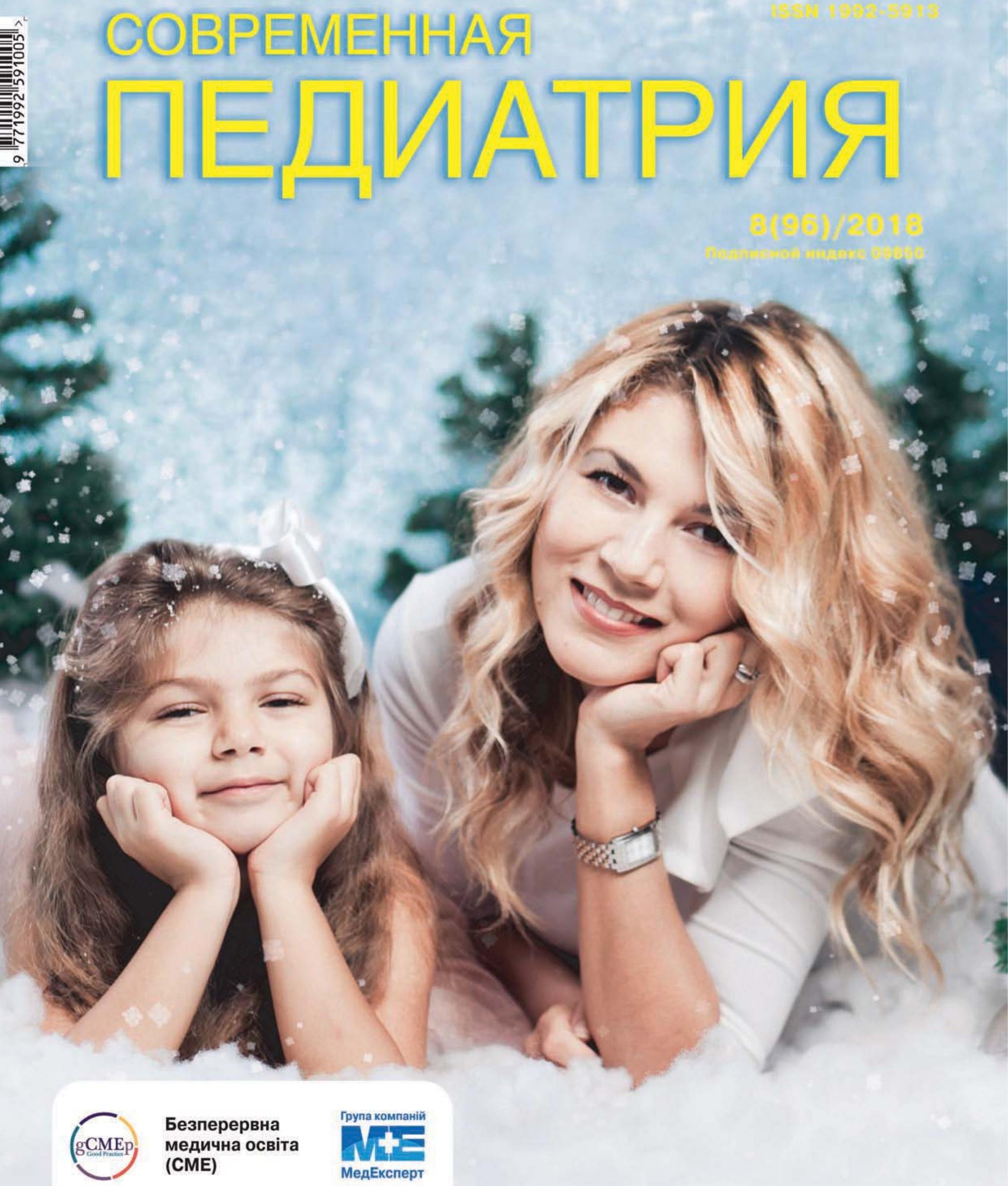

Забезпечення $2-x$ credit units

Навчальні семінари для лікарів різних спеціальностей 


\section{5 - 16 ЛИСТОПАДА 2019 Україна, Київ}

NOVEMBER 15 - 16, 2019 Ukraine, Kyiv

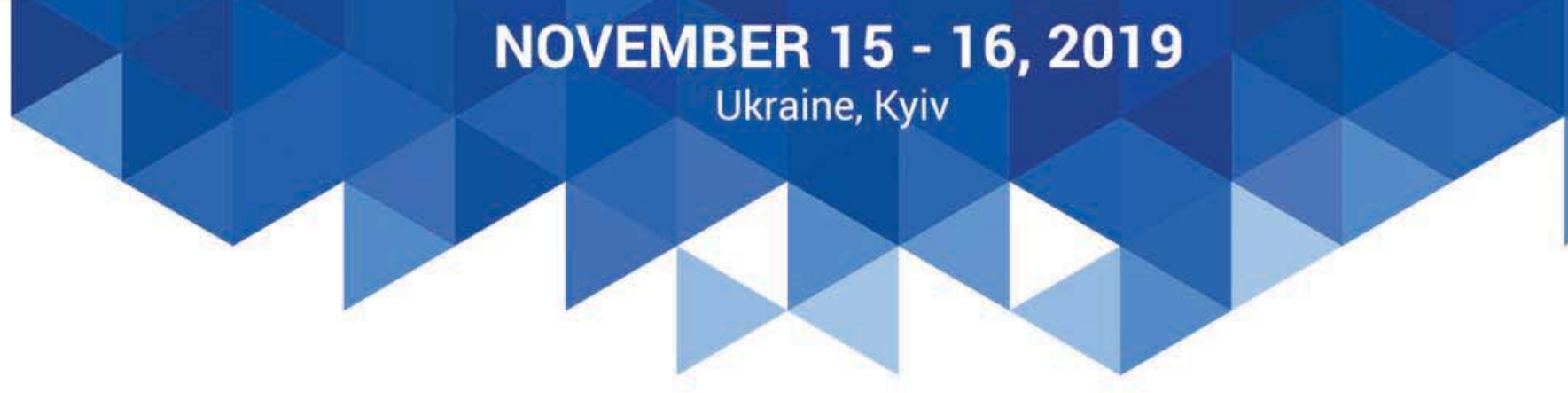

Il International congress

RATIONAL USE OF ANTIBIOTICS

\section{ANTIBIOTIC}

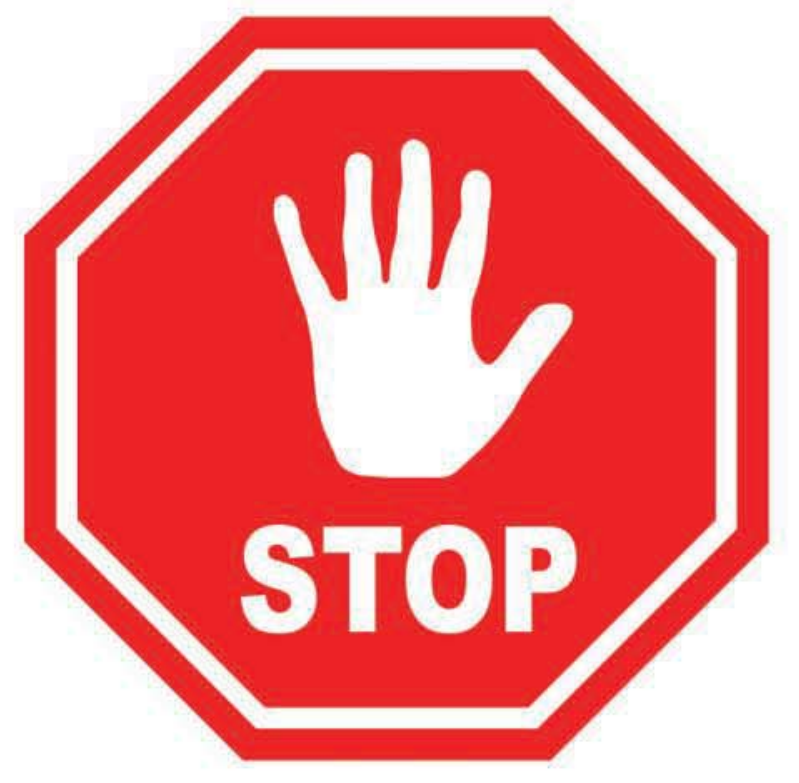

\section{RESISTANCE}

Другий міжнародний конгрес РАЦІОНАЛЬНЕ ВИКОРИСТАННЯ АНТИБІОТИКІВ У СУЧАСНОМУ СВІТІ 


\section{ПЕРЕМОЖНА СИЛА 100\% морської води}

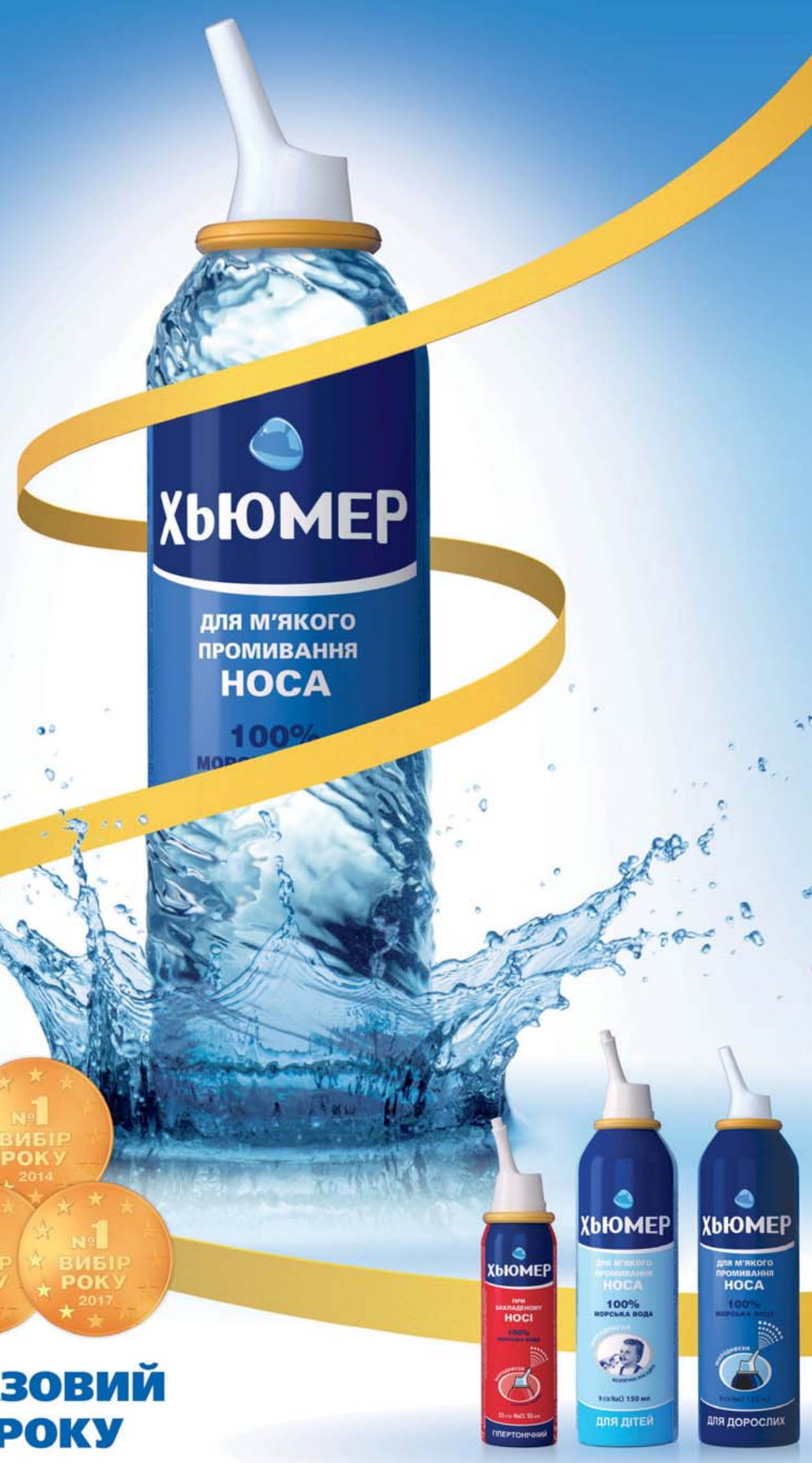




\section{Читайте нас на сайте: http://med-expert.com.ua \\ SHUPYK NATIONAL MEDICAL ACADEMY OF POSTGRADUATE EDUCATION \\ UKRAINIAN INSTITUTE OF STRATEGIC STUDIES OF THE MINISTRY OF HEALTH OF UKRAINE BAKHTIYAROVA D.O. \\ SOVREMENNAYA PEDIATRIYA Scientific and Practical Journal}

\section{Editor-in-Chief}

Berezhnoi V.V., Doctor of Medical Science, Professor of Pediatrics Department №2, Shupyk National Medical Academy of Postgraduate Education Valiulis A. (Lithuania), Professor, CEO of Clinic of Asthma, Allergy and Chronic Lung Diseases, CEO of EduCom (postgraduate education), Executive Committee member \& Treasurer of European Academy of Paediatrics (EAP/UEMS-SP)

Chief Scientific Adviser

Antipkin Yu.G., Academician of the National Academy of Medical Science of Ukraine, Director of the

SI «Institute of Pediatrics, Obstetrics and Gynecology, of the National Academy of Medical Science of Ukraine»

Deputies Chief Editor

Mamenko M.E., Doctor of Medical Science, Professor of Pediatrics Department №2 Shupyk National Medical Academy of Postgraduate Education

Volosovets A.P., Doctor of Medical Sciences, Professor, Head of Pediatrics Department №2 of Bogomolets National Medical University Scientific Editor

Marushko R.V., Doctor of Medical Sciences, Head of the Department of medical information technologies in pediatrics, obstetrics and gynecology, SI «Institute of pediatrics, obstetrics and gynecology NAMS of Ukraine», Kyiv

Project Director Bakhtiyarova D.O.

Executive Editor Sheiko I.A.

Layout and design Scherbatykh V.S.

EDITORIAL BOARD

Chairman of Editorial Board Moiseenko R.A.

Doctor of Medical Science, Professor, Deputy Rector, of the Shupyk National Medical Academy of Postgraduate Education of the Ministry of Health of Ukraine

Abaturov A.E

Aryayev M.L.

Banadyga N.V

Beketova G.V.

Bogmat L.F.

Vaildeliene L. (Lithuania)

Veres Gabor (Hungarian

Geppe N.A. (Russia)

Goida N.G.

Gorovenko N.G.

Hubertus von Voss

(Germany)

Dudnik V.M.

Yemets I.M.
Zaychenko A.V.
Zvolińska D. (Poland)
Ivanov D.D.
Yspaeva Zh.B.
(Kazakhstan)
Kvashnina L.V.
Kozlov R.S. (Russia)
Kozhyavkin V.I.
Kosakovskyi A.L.
Kramarev S.A.
Kurtianu A.M. (Moldova)
Labbe A. (France)

Livi P. (Italy)

Linne T. (Sroeden)

Maidannik V.G.

Mazur A. (Polland)

Martinyuk V.Yu.

Marushko Yu.V.

Mizernitckyi Yu.L. (Russia)

Nyan'kovskyi S.L.

Ovcharenko L.S.

Omelchenko L.I.

Osidak L.V. (Russia)

Okhotnikova E.N.

Pagava K.I. (Georgia)

Pilossoff V. (Bulgaria)
Prodanchuk M.G.
Puzievicz-Zmonarska A.
(Poland)
Rosenthal M. (Grate Britain)
Simanis R. (Latvia)
Smiyan A.I.
Slabkoi G.A.
Tokarchuk N.I.
Umanets T.R.
Urbonas V. (Lithuania)
Usonis V(Lithuania)
Hadjipanayis A. (Cyprus)

Husain S

(Grate Britain)

Chernyshov V.P.

Chernyshova L.I

Shadrin O.G.

Shamsiev F.S

(Uzbekistan)

Soder O.

(Sweden)

Shyshko G.O.

(Belarus)

Shun'ko E.E.

Yankovskyi D.S

PUBLISHERS GROUP OF COMPANIES MED EXPERT, LLC

Certificate of state registration MM КВ 15780-4252 IP from 27.10.2009 y., the Published since December 2003 y.

Published with the scientific support of the Institute of Pediatrics, Obstetrics and Gynecology, National Academy of Medical Science of Ukraine Publishing frequency -8 Times/Year

Qualified by the Higher Attestation Commission of Ukraine, the Decree of the Presidium of the Higher Attestation Commission of Ukraine № 1222 from 07.10 .2016

Recommended by the Shupyk National Medical Academy of Postgraduate Education, Protocol № 10 from 12.12 .2018

Recommended by the Academic Council of the Ukrainian Institute of Strategic Studies, the Ministry of Health of Ukraine, Protocol № 12 from 06.12 .2018 Passed for printing 25.12.2018

Mailing address:

GROUP OF COMPANIES MED EXPERT,

«SOVREMENNAYA PEDIATRIYA

p/b 80, Kiev, Ukraine, 04211

Tel./fax: +38 044 498-08-80

E-mail: pediatr@med-expert.com.ua

http://med-expert.com.ua

Format $60 \times 90 / 8$. Offset paper. Conventional printed
sheet. 13,95.
Total circulation is 8,000 copies.
Ord. №26.12/01 from 26.12 .2018
Printed from the final films
in the «Aurora-print» printing house,
Prichalnaya Str. 5, Kiev, tel. (044) 550-52-44
Certificate A00 № 777897 from 06.07 .2009

Format $60 \times 90$

Prichalnaya Str. 5, Kiev, tel. (044) 550-52-44

Certificate A00 № 777897 from 06.07.2009
All articles are reviewed. Total or partial reproduction by any means of the materials published in this edition is allowed only by written permission of the publisher. Advertiser takes responsibility for the content of advertisements.

(C) Shupyk National Medical Academy of Postgraduate Education, 2018 (C) Ukrainian Institute of Strategic Studies, Ministry of Health of Ukraine, 2018 (C) Bakhtiyarova D.O., 2018

"SOVREMENNAYA PEDIATRIYA» Journal is reviewed by the Institute of Information Recording Problems of the National Academy of Science of Ukraine

MEDLINE, Index Copernicus International, Directory of Open Access Journals (DOAJ), WorldCat,

РИНЦ, Science index (eLIBRARY.RU) и Google Scholar, CrossRef, Ulrich, Academic Resourse Index, Infobase index, Scientific Indexing Services, BASE, DRJI, Hinari, IIJIF, OAJI. 


\title{
СОВРЕМЕННАЯ ПЕАИАТРИЯ
}

\author{
Научно-практический педиатрический журнал

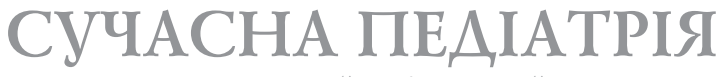

Науково-практичний педіатричний журнал

\section{Главный редактор}

Бережной В.В., доктор мед. наук, профессор кафедры педиатрии №2 НМАПО имени П.Л. Шупика

Валиулис А. (Литва), Профессор, Генеральный директор клиники астмы, аллергии и хронических заболеваний легких,

Генеральньй директор ЕdиСот (последипломное образование), Член Исполнительного комитета и казначей Европейской академии педиатрии (EAP / UEMS-SP)

Главный научный консультант

Антипкин Ю.Г., академик НАМН Украины, директор ГУ «ИПАГ НАМН Украины»

Заместители главного редактора

Маменко М.Е., доктор мед. наук, профессор кафедры педиатрии №2 НМАПО имени П.Л. Шупика

Волосовец А.П., ил.-корр. НАМН Украины, доктор мед. наук, профессор, зав. кафедрой педиатрии №2 НМУ имени А.А. Богомольца Научный редактор

Марушко Р.В., доктор мед. наук, зав. научным отделением медико-информащионных технологий в педиатрии, акушерстве и гинекологии, ГУ «ИПАГ НАМН Украинъ»

Директор проекта Бахтиярова Д.О.

Выпускающий редактор Шейко И.А.

Верстка и дизайн Щербатых В.С.

РЕДАКЦИОННАЯ КОЛЛЕГИЯ

Председатель редакционной коллегии Моисеенко Р.А

доктор мед. наук, профессор, проректор по научно-педагогической и лечебной работе НМАПО имени П.Л. Шупика МЗ Украины, Заслуженный врач Украины

$\begin{array}{ll}\text { Абатуров А.Е. } & \text { Емец И.Н. } \\ \text { Аряев Н.Л. } & \text { Зайченко А.В. } \\ \text { Банадыга Н.В. } & \text { Зволинска Д. (Польша) } \\ \text { Бекетова Г.В. } & \text { Иванов Д.Д. } \\ \text { Богмат Л.Ф. } & \text { Испаева Ж.Б. } \\ \text { Ваилделиене Л. (Литва) } & \text { (Казахстан) } \\ \text { Вереш Габор (Венгрия) } & \text { Квашнина Л.В. } \\ \text { Геппе Н.А. (Россия) } & \text { Козлов Р.С. } \\ \text { Гойда Н.Г. } & \text { (Россия) } \\ \text { Горовенко Н.Г. } & \text { Козявкин В.И. } \\ \text { Губертус фон Фосс } & \text { Косаковский А.Л. } \\ \text { (Германия) } & \text { Крамарев С.А. } \\ \text { Дудник В.М. } & \text { Куртяну А.М. (Молдова) }\end{array}$

Лаббе Андре (Франиия)
Ливи П. (Италия)
Линне Т. (Швещия)
Майданник В.Г.
Мазур А. (Польиа)
Мартынюк В.Ю.
Марушко Ю.В.
Мизерницкий Ю.Л.
(Россия)
Няньковский С.Л.
Овчаренко Л.С.
Омельченко Л.И.
Осидак Л.В. (Россия)

Охотникова Е.Н.
Пагава К.И. (Грузия)
Пилоссофф В.(Болгария)
Проданчук Н.Г.
Пузиевич-Змонарска А.
(Польша)
Розенталь М.
(Великобритания)
Симанис Р.(Латвия)
Слабкий Г.А.
Смиян А. И.
Токарчук Н.И.
Уманец Т.Р.

Урбонас В. (Литва)

Усонис В. (Литва)

Хаджипанаис А. (Кипр)

Хусаин Ш.

(Великобритания)

Чернышов В.П.

Чернышова Л.И.

Шадрин О.Г.

Шамсиев Ф.С. (Узбекистан)

Шедер О. (Швеция)

Шишко Г.А. (Беларусь)

Шунько Е.Е.

ИЗДАТЕЛЬ ООО «ГРУППА КОМПАНИЙ МЕД ЭКСПЕРТ»

Свидетельство о государственной регистрации СМИ КВ № 15780-4252 ПР от 27.10.2009 г.

Издается при научной поддержке ГУ «Институт педиатрии, акушерства и гинекологии НАМН Украины» Издается с декабря 2003 г.

Периодичность выхода -8 раз в год

Приказом МОН Украины № 1222 от 07.10.2016 журнал «Современная педиатрия» включен в перечень специализированных научных изданий Украины в области медицинских наук. В издании могут быть опубликованы основные результаты диссертационных работ

Утверждено ученым советом Национальной медицинской академии последипломного образования им. П.Л. Шупика Протокол № 10 от 12.12 .2018 г. Утверждено ученым советом Украинского института стратегических исследований МЗ Украины Протокол № 12 от 06.12 .2018 г. Подписано к печати 25.12.2018 г.

Адрес для переписки:

OОО «Группа компаний Мед Эксперт»,

«Современная педиатрия»

а/я 80, г.Киев-211, Украина, 04211 ,

Тел./факс: +38 044 498-08-80

E-mail: pediatr@med-expert.com.ua

http://med-expert.com.ua/

\author{
Формат $60 \times 90 / 8$. Бумага офсетная. \\ Усл. печ. л. 17. Уч.-изд. л. 13, 95. \\ Общий тираж 8000 экз. \\ Зак. № 26.12/01 от 26.12.2018 \\ Отпечатано с готовых фотоформ \\ в типографии «Аврора-принт», \\ г. Киев, ул. Причальная, 5, тел., (044) 550-52-44 \\ Свидетельство субъекта издательского дела: \\ A00 № 777897 от 06.07.2009 г.
}

Все статьи рецензированы. Полная или частичная перепечатка и тиражирование каким-либо образом материалов, опубликованных в этом издании, допускается только по письменному разрешению редакции. Ответственность за содержание рекламных

материалов несет рекламодатель.

(c) Национальная медицинская академия последипломного образования МЗ Украины, 2018 (C) Украинский институт стратегических исследований МЗ Украины, 2018
() Бахтиярова Д.О., 2018

\section{Внимание! Подписаться на журнал «Современная педиатрия» Вы можете во всех отделениях связи Украины Подписной индекс 09850}

\section{Журнал “Современная педиатрия» реферируется Институтом проблем регистрации информации НАН Украины}

Журнал «Современная педиатрия» включен в наукометрические, реферативные и поисковые базы данных: MEDLINE, Index Copernicus International, Directory of Open Access Journals (DOAJ), WorldCat,

РИНЦ, Science index (eLIBRARY.RU) и Google Scholar, CrossRef, Ulrich, Academic Resourse Index, Infobase index,

Scientific Indexing Services, BASE, DRJI, Hinari, IIJIF, OAJI. Статьям журнала «Современная педиатрия» присваивается DOI
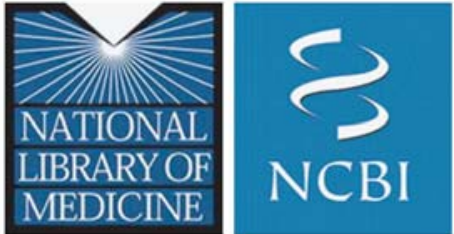
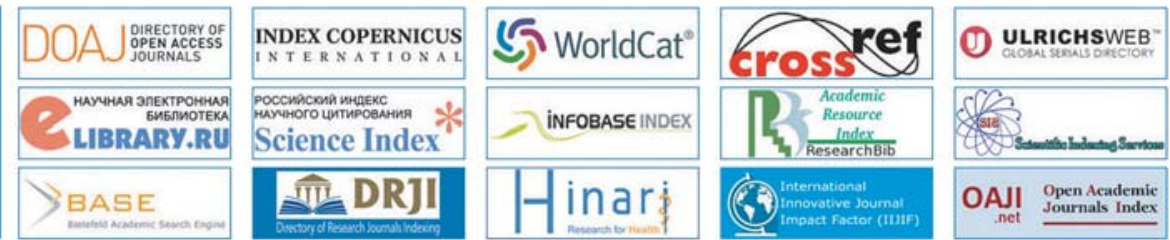
МИНИСТЕРСТВО ЗДРАВООХРАНЕНИЯ УКРАИНЫ НАЦИОНАЛЬНАЯ МЕДИЦИНСКАЯ АКАДЕМИЯ ПОСЛЕДИПЛОМНОГО ОБРАЗОВАНИЯ ИМЕНИ П.Л. ШУПИКА УКРАИНСКИЙ ИНСТИТУТ СТРАТЕГИЧЕСКИХ ИССЛЕДОВАНИЙ МЗ УКРАИНЫ

\section{СОВРЕМЕННАЯ ПЕАИАТРИЯ}

Научно-практический педиатрический журнаА

\section{СУЧАСНА ПЕАIАТРІЯ}

Науково-практичний педіатрічний жкурнаА
THE MINISTRY OF HEALTHCARE OF UKRAINE SHUPYK NATIONAL MEDICAL ACADEMY OF POSTGRADUATE EDUCATION

UKRAINIAN INSTITUTE OF STRATEGIC STUDIES OF THE MINISTRY OF HEALTH OF UKRAINE

\section{SOVREMENNAYA PEDIATRIYA \\ Scientific and Practical Journal}

$8(96) / 2018$

\section{СОБыТИя}

Пост-реліз I Міжнародного конгресу «Раціональне використання антибіотиків. Antibiotic Resistance Stop!”

(Киї̈, 15-16 листопада 2018 року)

Пост-реліз зустрічі з президентом Акредитаційної ради безперервної медичної освіти США Гремом Макманом (11 грудня 2018 року)

\section{ОРИГИНАЛЬНЫЕ ИССЛЕДОВАНИЯ}

Бекетова Г.В., Савінова К.Б., Дубогай О.Д., Міщерська Г.Д.

Вплив здоров'язберігаючих технологій на стан здоров'я дітей молодшого шкільного віку

Дорош О.І., Цимбалюк-Волошин І.П., Бодак Х.І., Поліщук Р.С., Степанюк А.І., Воробель О.І., Скоропад Л.Л., Трояновська О.О., Козлова О.І., Мих А.М., Середич Л.П., Глинська О.В. Прогрес у лікуванні гострої лімфобластної лейкемії: 25 років застосування міжнародних протоколів у відділенні дитячої гематології Західноукраїнського спеціалізованого дитячого медичного центру

Косаківська І.А.

Досвід виконання аденотомії у дітей

Хасанова С.С., Камилова А.Т.

Особенности экзокринной функции поджелудочной железы и непереносимости лактозы у недоношенных детей

Лісецька І.С., Рожко М.М., Куцик Р.В.

Антилізоцимна активність симбіонтів ясен у процесі комплексного лікування генералізованого катарального гінгівіту у підлітків з хронічним гастродуоденітом

\section{EVENTS}

8 Post-release of I International Congress

"Rational use of antibiotics.

Antibiotic Resistance Stop!"

(Kyiv, November 15-16, 2018)

14 Post-Release of the Meeting with the President of US Accreditation Council for Continuing Medical Education Graham McMahon (December 11, 2018)

\section{ORIGINAL ARTICLES}

17 Beketova H.V., Savinova K.B., Dybohay O.D., Mishcherska H.D. The influence of the health saving technologies on the health of the children of the primary-school age

22 Dorosh O., Tsymbalyuk-Voloshyn I., Bodak Kh., Polishchuk R., Stepanyuk A., Vorobel O., Skoropad L., Troyanovska O., Kozlova O., Myh A., Seredych L., Hlynska O.

Progress in the treatment of acute lymphoblastic leukemia: 25 years of application of international protocols in the Department of Pediatric Hematology of the Western Ukrainian Specialized Children's Medical Center

37 Kosakivska I.A.

Experience in the implementation of adenotomy in children

42 Khasanova S.S., Kamilova A.T. Features of the exocrine pancreatic function and lactose intolerance in premature babies

50 Lisetska I.S., Rozhko M.M., Kutsyk R.V. Antilysocyme activity of the symbionts of the gums in the process of complex treatment generalizovannoe catarrhal gingivitis in adolescents with chronic gastroduodenitis 


\section{ГОЛОВНІ ПОДПЇ У ГАЛУЗІ ОХОРОНИ ЗДОРОВ'Я УКРАӤНИ}

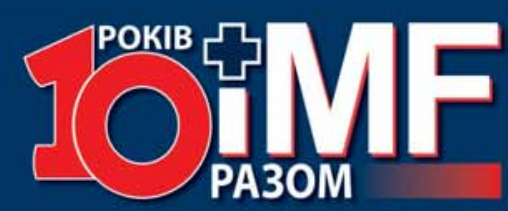

\section{X ЮВІЛЕЙНИЙ МІЖНАРОДНИЙ МЕДИЧНИЙ ФОРУМ

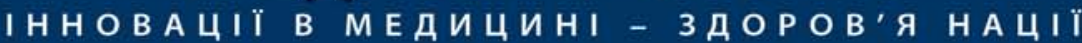

(.ं.) VII МІЖНАРОДНИЙ МЕДИЧНИЙ КОНГРЕС ВПРОВАДЖЕННЯ СУЧАСНИХ ДОСЯГНЕНЬ МЕДИЧНОЇ НАУКИ У ПРАКТИКУ ОХОРОНИ ЗДОРОВ'Я УКРАЇНИ

\section{$\because$ HCM}

За підтримки:

). Президента України

Під патронатом:

(1) Комітету Верховної Ради України з питань охорони здоров'я

IV МІЖНАРОДНИЙ ФОРУМ

\section{МЕНЕДЖМЕНТ В ОХОРОНІ ЗДОРОВ'Я}

Офіційна підтримка:

Кабінету Міністрів Міністерства охорони Кйвської міської України здоров'я України ді) державної адміністрації

\section{Організатори:}

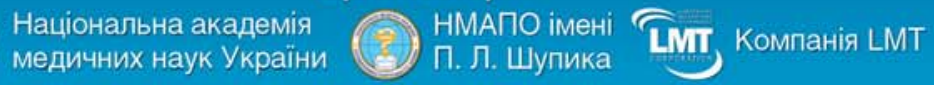

Генеральний партнер:

Canon

Осріційний партнер:

(MPE

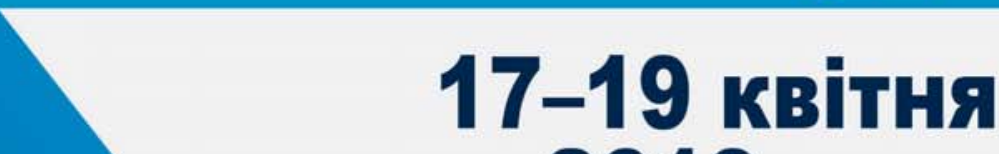
2019 року

\section{KPAїH \\ 35 \\ 65 \\ НАУКОВИХ ЗАХОДІВ

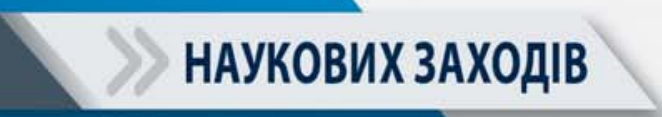
400 800
ДОПОВІДАЧІВ
УВАГА! НОВЕ МІСЦЕ ПРОВЕДЕННЯ ФОРУМУ

ВІДВІДУВАЧІВ

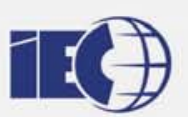

Міжнародний Виставковий Центр м. Київ, Броварський пр-т, 15 станція метро «Лівобережна"

(5) MEDICAEXPO Мжнародна виставка охорони здоров'я PHARMAEXРО Міжнародна фармацевтична виставка

Весь спектр обладнання, техніки, інструментарію для медицини, новинки фармацевтичних препаратів від світових та вітчизняних виробників

$\checkmark$ Науково-практичні заходи

Школи та майстер-класи на діючому обладнанні

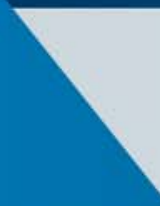

3 питань участі у виставках:

C +380 (44) 206-10-16

@ med@Imt.kiev.ua
3 питань участі у Конгресі:

c +380 (44) 206-10-99

@ info@medforum.in.ua 
Фролова Т.В., Амаш А.Г.

Вплив виду вигодовування на рівень цинку та фізичний розвиток дітей першого року життя

Синяк Ю.П., Купріяненко А.В.

Захворюваність на вітряну віспу населення Житомирської області (дитячого і дорослого) у 2015-2017 роках

\section{КЛИНИЧЕСКИЙ СЛУЧАЙ}

Макеева Н.И., Одинец Ю.В.,

Поддубная И.Н.

Случай анемии Фанкони у ребенка

Дорош О.І., Хім'як Л.С., Кушарська О.В., Василів І.Л., Мелько І.П., Мих А.М.

Інвазивний мукормікоз:

проблеми діагностики і лікування

Макеева Н.И., Одинец Ю.В., Поддубная И.Н.

Остеонекроз как осложнение

полихимиотерапии у детей, страдающих острым лейкозом

\section{ОБЗОРЫ}

Бегларян С.А., Чернишова Л.І.

Підходи до розробки клінічних критеріїв випадків, підозрілих щодо первинного імунодефіциту (огляд літератури)

Мочульська О.М., Чорномидз І.Б., Горішний І.М. Сучасна стратегія лікування атопічного дерматиту у дітей (огляд літератури)

\section{ШКОЛА}

\section{ПРАКТИЧЕСКОГО ВРАЧА}

Квашніна Л.В., Чернишов В.П.,

Матвієнко І.М., Ігнатова Т.Б., Осипчук Д.В.

Вплив лікарського засобу “Резістол ${ }^{\circledR}$ на гуморальний та клітинний імунітет дітей з рекурентними та гострими вірусними респіраторними захворюваннями: результати дослідження

Федір Юрочко

Фарингіт і деякі інші.

Сучасні тенденції
Frolova T.V., Amash A.G.

Influence of a type of feeding on the zinc's level and the physical development of infants

Sinyak Yu.P., Kupryianenko A.V.

The incidence of chickenpox of the population of Zhytomyr region (child and adult) in 2015-2017

\section{CLINICAL CASE}

Makieieva N., Odinets Yu., Poddubnaya I.

Case of Fanconi anemia in a child

70 Dorosh O.I., Khimyak L.S., Kusharska O.V., Vasyliv I.L., Melko I.P., Mykh A.M. Invasive Mucormycosis: Problems of Diagnosis and Treatment

87 Makieieva N., Odinets Yu., Poddubnaya I. Osteonecrosis as a complication of polychemotherapy in children suffering from acute leukemia

\section{REVIEWS}

92 Beglaryan S.A., Chernyshova L.I. Approaches to the development of clinical criteria for cases suspected of primary immunodeficiency (literature review)

Mochulska O.M., Chornomydz I.B., Horishnyi I.M. Clinical efficacy and immunomodulatory effect of allergen-specific immunotherapy with prolonged course of probiotics at atopic dermatitis in children

\section{PRACTICAL DOCTOR SCHOOL}

104 Kvashnina L.V., Chernyshov V.P., Matvienko I.M., Ignatova T.B., Osypchuk D.V. Influence of Resistol ${ }^{\circledR}$ Drug on Humoral and Cellular Immunity of Children with Recurrent and Acute Viral Respiratory Diseases: Research Findings

114 Yurochko F.

Pharyngitis and some others.

Modern tendencies 


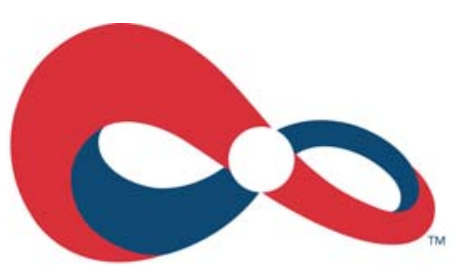

WORLD THROMBOSIS DAY

\subsection{0 .2019}

\section{III науково-практична конференція, Присвячена WORLD THROMBOSIS DAY}

«Тромбопрофілактика в Україні. Сучасні світові тенденції»

м. Київ, вул. Антоновича 52, конференц-хол ДЕПО

Надається можливість On-line перегляду

Учасники отримують національний та міжнародний сертифікати

Захід включено до реєстру з'їздів, конгресів,

симпозіумів та науково-практичних конференцій на 2019 рік

\section{Обов'язкова реєстрація на сайті wtd-ukraine.org}

\section{ЗА ПІДТРИМКИ:}

\&S | МIHICTEPCTBO

ОХОРОНИ

ЗДОРОВ'Я

УКРАІНИ

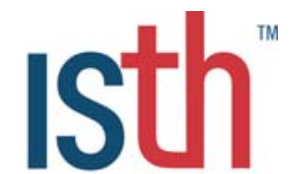

International Society on Thrombosis and Haemostasis
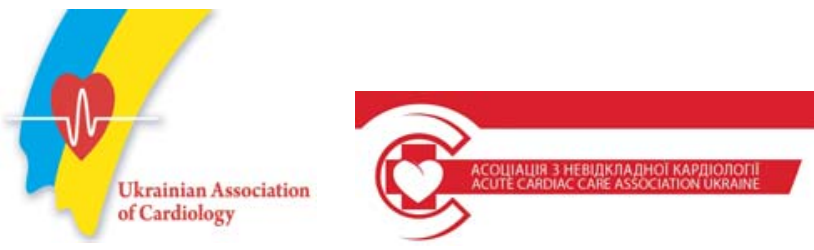
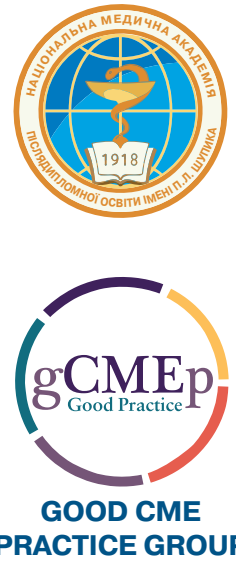

Група компаній 
ANTIBIOTIC

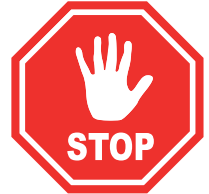

RESISTANCE
Пост-реліз

I Міжнародного конгресу «Раціональне використання антибіотиків. Antibiotic Resistance Stop!” (Київ, 15-16 листопада 2018 року)
Група компаній

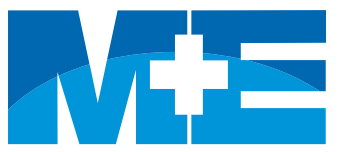

МедЕксперт
$\mathrm{B}$ провадження антибіотиків стало революцією у боротьбі з інфекційними хворобами. Антибіотики також використовуються для лікування і профілактики інфекційних ускладнень при хірургічних втручаннях і маніпуляціях (у хіміотерапії, інтервенційній кардіології, трансплантації органів, акушерстві, неонатології, педіатрії).

Але в наш час будь-хто, будь-якого віку, у будь-якій країні може захворіти на антибіотикорезистентну інфекцію (ВООЗ). Поширення резистентності до антибактеріальних лікарських засобів стало глобальною загрозою людству, воно призводить до зменшення ефективності лікування інфекцій, небезпечних для життя; збільшення частоти та тривалості госпіталізацій; витрат на охорону здоров'я; рівня смертності пацієнтів.

За останні роки не впроваджений жоден антибактеріальний препарат нового класу для лікування інфекцій, викликаних грамнегативними збудниками, зокрема тому, що розробка нових антибіотиків залишається малопривабливою для інвестицій внаслідок складності наукових досліджень, скорочення термінів застосування нового засобу через швидкий розвиток резистентності мікроорганізмів до нього.

Отже, поширення антибіотикорезистентності (АБР) і відсутність нових ефективних антибактеріальних лікарських засобів визначають загальнодержавне значення цієї проблеми, що потребує вжиття невідкладних заходів.
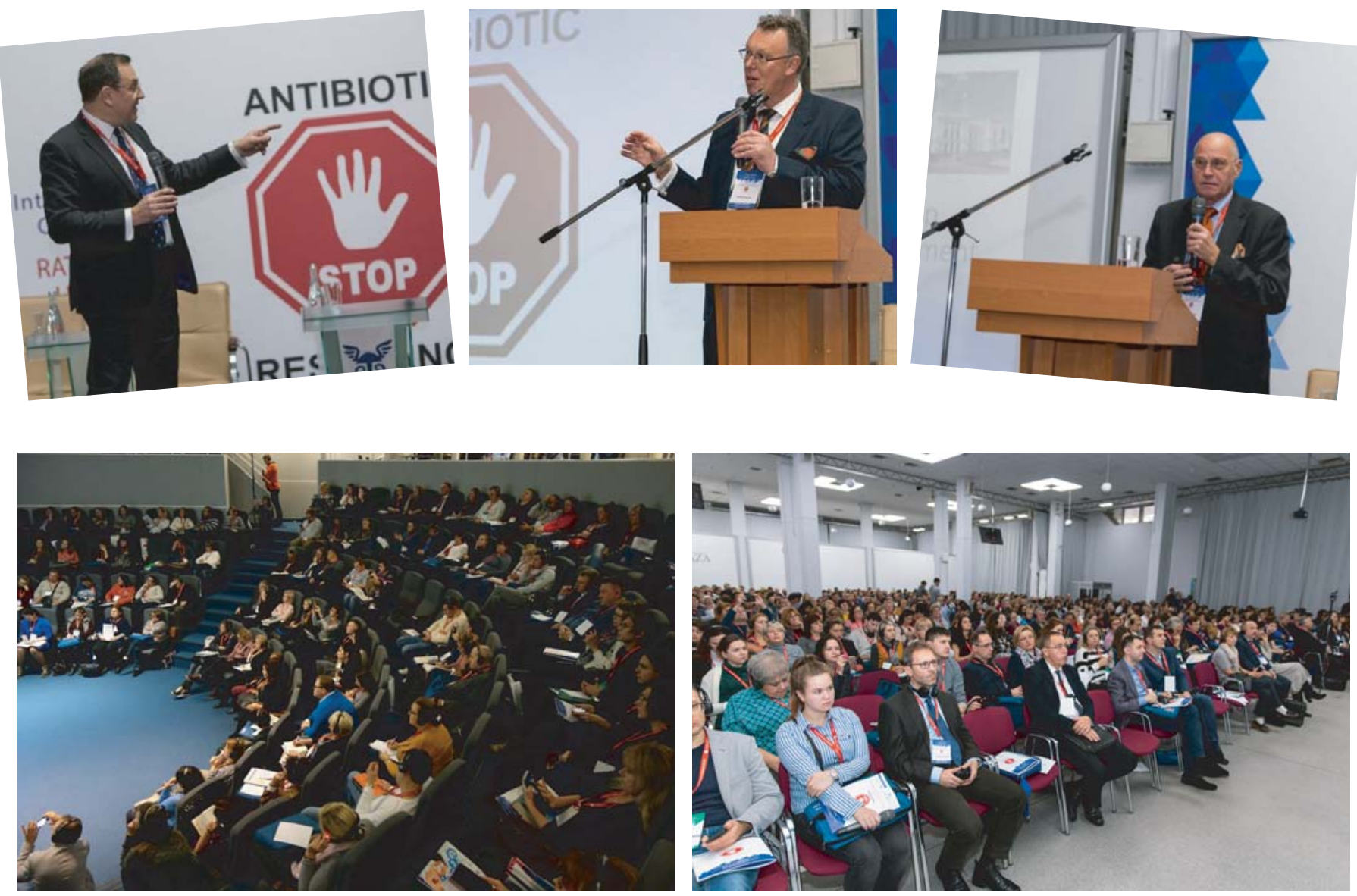

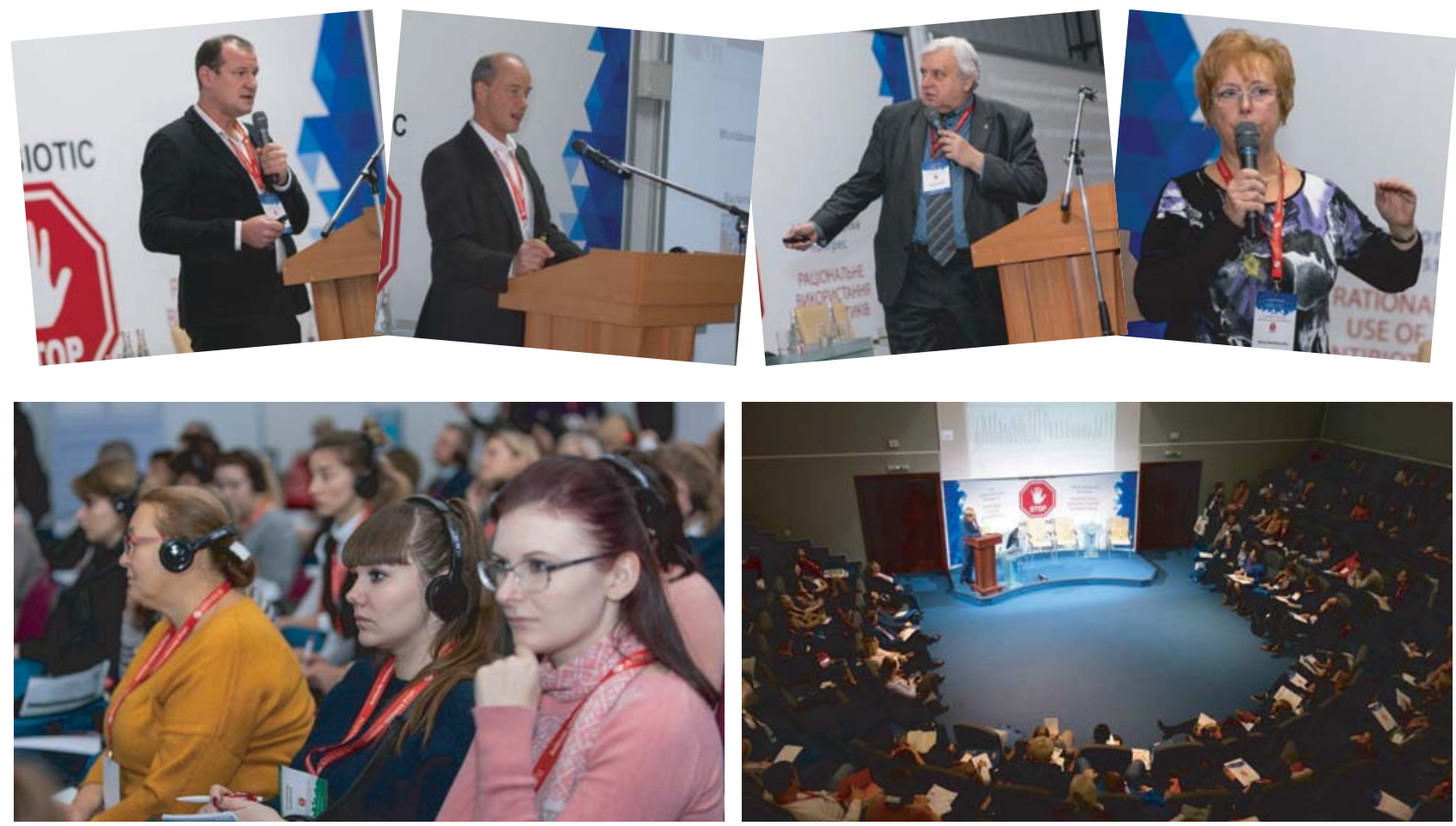

15-16 листопада 2018 р. у м. Києві відбувся I Міжнародний конгрес «Раціональне використання антибіотиків. Antibiotic Resistance Stop!». Конгрес було організовано у рамках Всесвітнього тижня правильного використання антибіотиків Групою компаній «МедЕксперт» у співпраці з Британським товариством 3 антимікробної хіміотерапії та за підтримки МОЗ України, НМАПО імені П.Л. Шупика, Української асоціації за доцільне використання антибіотиків та Асоціації анестезіологів України.

Захід зібрав близько 700 провідних фахівців у галузі охорони здоров'я - практичних

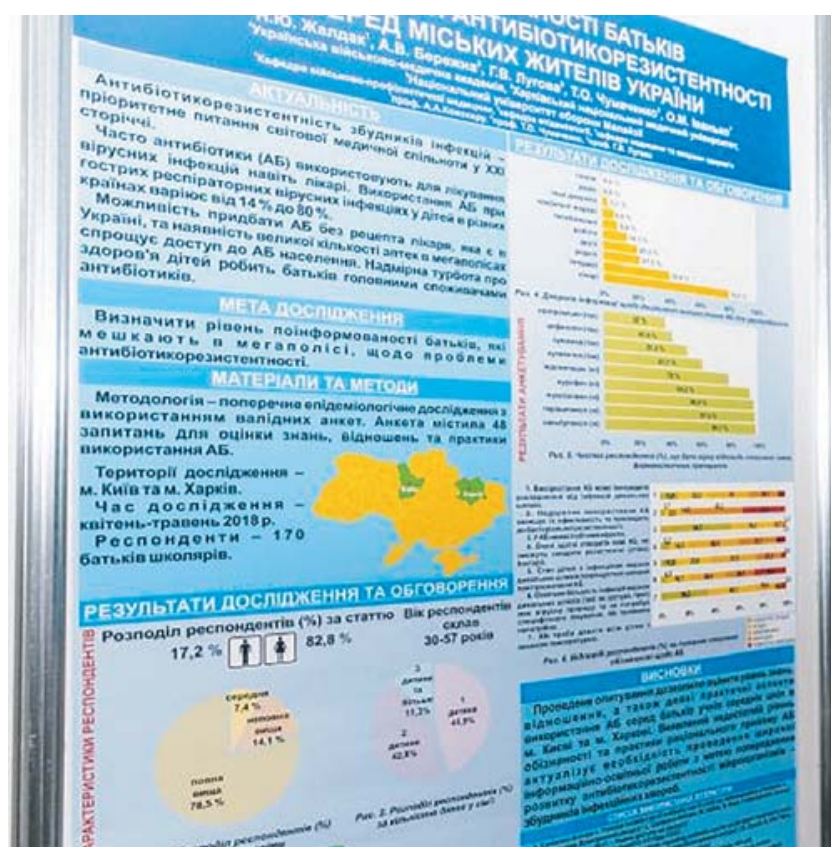

лікарів, фармакологів, мікробіологів із восьми країн світу. Учасники заслухали 60 доповідей та взяли участь у роботі 6 майстеркласів з управління АБР. Основними темами заходу стали: проблема зниження ефективності антибіотиків (АБ), вироблення стратегії стримування АБР, терапія стійких до АБ бактеріальних інфекцій при різних клінічних станах.

Конгрес став першим в Україні масштабним заходом, проведеним відповідно до вимог та стандартів акредитаційної ради безперервної медичної освіти США (АССМЕ) у рамках спів- 
праці Siyemi Learning та Групи компаній МедЕксперт. Учасники конгресу отримали 14 міжнародних кредитів - AMA PRA Category 1 Credits $^{T M}$, які підтверджують якість післядипломного навчання на міжнародному рівні.

Іноземних та вітчизняних доповідачів об'єднала думка, що АБР ставить під загрозу основи сучасної медицини. Систематичне неправильне і надмірне застосування АБ у медицині, харчовій промисловості, сільському господарстві проблема світового масштабу. Щороку зростає кількість смертей від інфекцій, спричинених антибіотикорезистентною флорою.

У своїх виступах доповідачі зазначили недосконалість системи інфекційного контролю в Україні; недоступність сучасних лабораторних методів діагностики АБР, медичних виробів для експрес-діагностики in vitro; невідповідність між знаннями про біологічні механізми дії антибіотиків та клінічною практикою; фактично відсутність освітніх програм з проблем АБР та кваліфікованого персоналу 3 мікробіологічної діагностики; недостатність та нераціональне використання фінансових ресурсів. Велика увага була приділена перспективам наукових досліджень, підготовки наукових та науково-педагогічних кадрів.

У травні 2015 р. ВООЗ прийняла Глобальний план дій щодо стійкості до протимікробних засобів. В Україні співробітниками НМАПО імені П.Л. Шупика розроблено проект Національної стратегії та Плану дій із боротьби з АБР. Одними з основних завдань стратегії є привернути увагу до проблеми, покращити обізнаність медичних працівників та досягти розуміння на всіх рівнях, у тому числі через комунікацію, просвітницькі заходи та навчання. У березні 2018 р. МОЗ України оприлюднило для обговорення проект розпорядження Кабінету Міністрів України «Про схвалення Державної стратегії щодо реалізації державної політики зі стримування розвитку стійкості до протимікробних препаратів 2018-2022 роки». План заходів у рамках стратегії, зокрема, містить розроблення механізму контролю за дотриманням відпуску АБ аптечними закладами виключно за рецептами лікарів; удосконалення та розширення системи нагляду за АБР; обмеження застосування протимікробних препаратів у якості стимуляторів росту у тваринництві, птахівництві та рослинництві; перегляд та оновлення клінічних протоколів з урахуванням міжнародних стандартів та рекомендацій щодо використання лікарських засобів широ- кого спектра дії; приведення у відповідність до вимог ЄС лабораторної діагностики інфекційних хвороб та визначення чутливості мікроорганізмів до протимікробних препаратів.

У рамках конгресу в окремій секції розглядались питання управління АБР у педіатрії. 3 доповідями виступили: Єлизавета Шунько завідувач кафедри неонатології НМАПО імені П.Л. Шупика, Марцена Зелінська - завідувач кафедри дитячої анестезіології та інтенсивної терапії Вроцлавського медичного університету, Марина Маменко - декан педіатричного факультету НМАПО імені П.Л. Шупика, Ростислав Марушко - консультант ДУ «ППАГ імені академіка О.М. Лук'янової НАМН України».

У ході обговорення було зазначено, що формування резистентності до антимікробних препаратів починається в короткі терміни після їх призначення. Мутантні клітини з'являються протягом кількох годин і швидко розмножуються, незважаючи на присутність антибіотика. До кінця лікування, навіть якщо воно проведено відповідно до рекомендацій, бактерії, на які впливав антибіотик, гинуть або припиняють своє розмноження, в той час як мутантні клітини присутні у значній кількості. Також у формуванні резистентності до антибіотиків важливу роль відіграє їх нераціональне застосування короткі курси, низькі дози, відсутність визначення чутливості антибіотиків до мікрофлори. Особливо слід акцентувати увагу на препаратах, виробництво яких не відповідає стандартам, - це так звані counterfait, або fake, які широко застосовуються в країнах, що розвиваються, де контроль за імпортованими препаратами досить низький.

До одного з найбільш ефективних методів зниження АБР належить імунопрофілактика захворювань, для лікування яких використовуються протимікробні препарати. Імунопрофілактика в даний час розглядається як частина довгострокової стратегії боротьби з глобальною проблемою АБР, що в кінцевому підсумку може знизити залежність людства від протимікробних препаратів. На відміну від АБ, вакцини мають перевагу, взаємодіючи з імунною системою. Відзначено дві фундаментальні відмінності між антибіотиками і вакцинами:

- фактор часу: коли призначається АБ, в організмі вже є значна кількість бактерій і їх різні штами, що створює умови для формування резистентності. На відміну від АБ, вакцини вводяться до інфікування організму. Їх роль 


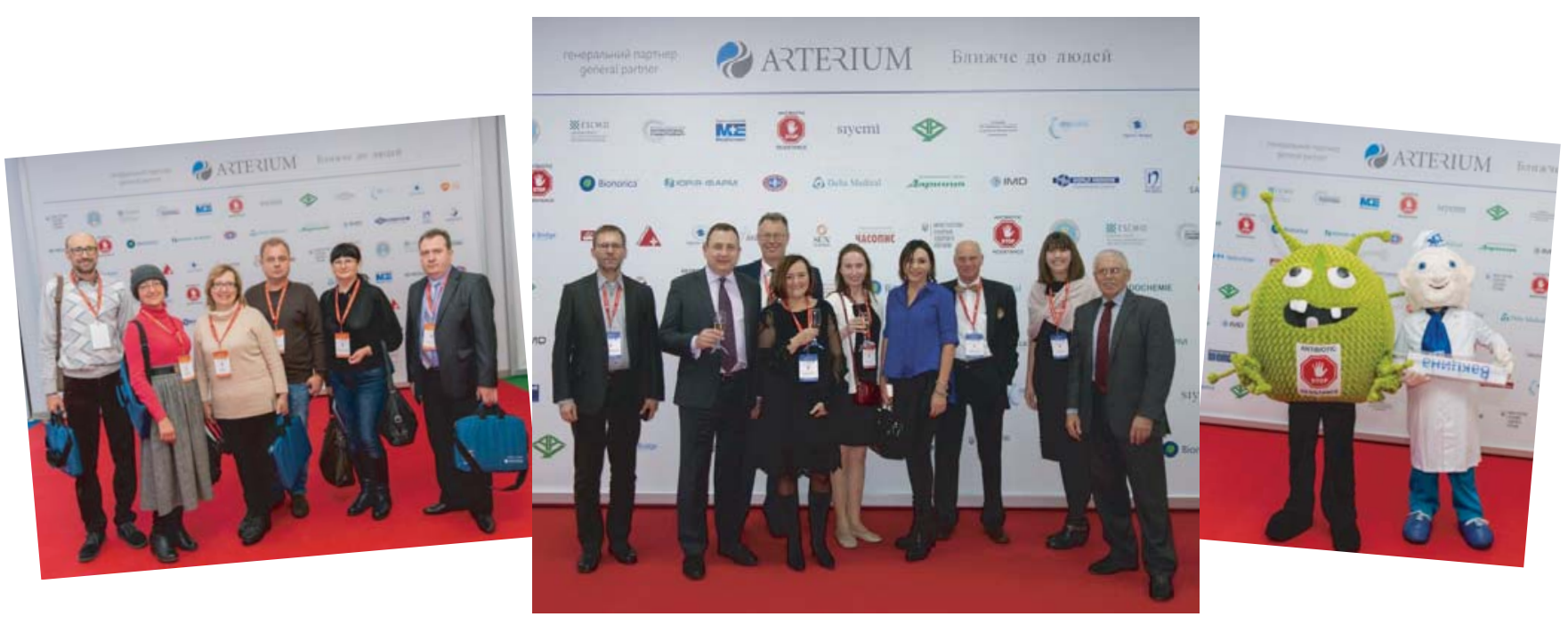

полягає в тому, що вони індукують імунну відповідь на можливе надходження патогенів у майбутньому, попереджаючи розмноження цих бактерій в організмі;

- фактор захисту: АБ зазвичай діють, націлюючись на певні білкові структури або механізми, що призводить до руйнування або пригнічення росту бактерій. Причому навіть однієї мутації може бути достатньо для того, щоб ліки перестали розпізнаватися, що спричиняє стійкість бактерії до антибактеріальних препаратів. На відміну від АБ, вакцини індукують імунний захист, який здатний протистояти величезній різноманітності бактеріальних білків/антигенів. Вакцини захищають від бактеріальних інфекцій, пригнічуючи колонізацію організму і подальше інфікування. Таким чином, відсутність необхідності призначення АБ знижує ризик розвитку резистентності до них.

Доповідачі звернули увагу присутніх на те, що лікування інфекцій у новонароджених повинно починатись лише за наявності клінічних ознак, лабораторні показники відіграють допоміжну роль у визначенні тривалості курсу або ефективності препарату, з бактеріальних досліджень діагностично значущими вважаються кров, ліквор, сеча. Усі інші локуси показують колонізацію. Принцип лікування - вчасно розпочати, а якщо підозра на інфекцію не підтвердилась - відмінити АБ на 3-ю добу.

Усі присутні вважали, що призначення АБ при ГРЗ у дітей має бути обмеженим, оскільки такі інфекції найчастіше викликані вірусами, проти яких АБ неефективні. За необхідності призначення АБ, вибір препарату повинен грунтуватися на міжнародних та вітчизняних рекомендаціях та на концепції SMART USE «розумне використання». У амбулаторних пацієнтів перевагу слід надавати АБ у пероральній формі випуску. Внутрішньовенне введення розглядається якщо дитина у важкому стані, має високий ризик системних ускладнень, наявна блювота, синдром мальабсорбції будь-якого генезу, низька комплаєнтність перорального прийому. Внутрішньом'язовий шлях введення не розглядається в жодному міжнародному протоколі! Ефективність терапії та необхідність зміни АБ оцінюється через 48-72 години від початку лікування.

Конгрес став важливим кроком на шляху подолання АБР в Україні. Учасники відзначили відсутність належного фінансування досліджень у сфері АБР; недостатність освітніх програм; гострий дефіцит швидких мікробіологічних тест-систем; значну поширеність необгрунтованих призначень АБ у рутинній практиці, відсутність своєчасної корекції та відміни терапї АБ.

Учасники визнали необхідність масштабної системної діяльності з управління АБР. Вони працюватимуть задля того, щоб в наступному році мати затверджений національний план боротьби з АБР та розпочати створення карти резистентності України. А 15-16 листопада 2019 р. фахівці матимуть змогу знову зустрітися на II Міжнародному конгресі «Раціональне використання антибіотиків у сучасному світі. Antibiotic Resistance Stop!».

\section{wwow.antibiotic-congress.com}




\section{РЕЗОЛЮЦІЯ \\ I Міжнародного конгресу \\ «Раціональне використання антибіотиків. Antibiotic resistance STOP! ” (Київ, 15-16 листопада 2018 року)}

Учасниками Конгресу визнана потреба в масштабних та постійних діях з управління АБР та визначено - основні стратегічні цілі: досягти розуміння у суспільстві проблем АБР; раціонально застосовувати існуючі протимікробні препарати та медичні вироби для діагностики in vitro в охороні здоров'я людини та тварин; створити умови для стимулювання розробки нових методів терапії та лабораторної діагностики АБР.

Шляхом широкого обговорення сформульовані основні принципи управління АБР:

- «Єдине здоров'я» - виявлення АБР в Україні та внесення даних до Resistanсе Мар. Здійснення контролю за використанням антибіотиків в охороні здоров'я, в якості стимуляторів росту та ветеринарній медицині та аграрному секторі відповідно до міжнародних стандартів.

- Співпраця: міждисциплінарна (між різними фахівцями в галузі медицини); міжвідомча (клінічна і ветеринарна медицина тощо); міжсекторальна (політичні партії, місцева влада, промисловість, фінансові органи, заклади вищої освіти, наукові установи, громадські організації, професійні асоціації, страхові компанії тощо повинні спільно працювати з метою посилення контролю над АБР); міжнародна (спільні епідеміологічні та інші наукові дослідження, клінічні випробування тощо).

- Визнання мікробіологічної діагностики та тестування чутливості виділених збудників до антимікробних препаратів невід'ємною частиною антимікробної терапії.

Важливими напрямами належної практики визнано:

1) запобігання виникненню інфекцій (для зменшення потреби в антибіотиках):

- організація ефективних програм та заходів інфекційного контролю в закладах охорони здоров'я відповідно до міжнародних стандартів;
- подальше впровадження програм вакцинації для профілактики бактеріальних інфекцій;

- вакцинація від вірусних інфекцій тощо;

2) впровадження нових методів діагностики в практику охорони здоров'я через включення ïх в стандарти та ринкові стимули їх застосування;

3) подальший розвиток фармаконагляду, зокрема оптимізація процесу реєстрації випадків інфекцій, спричинених АБР, у тому числі пов'язаних з наданням медичної допомоги, які мають клінічне та епідеміологічне значення;

4) удосконалення локальних протоколів з призначення антибіотиків для забезпечення:

- виключення призначення антибіотиків за відсутності показань;

- правил відбору зразків біологічного матеріалу від пацієнтів для мікробіологічного дослідження (мікроскопія, культуральне дослідження), визначення чутливості виділеного збудника до антибактеріальних лікарських засобів з дотриманням вимог правил забору та транспортування біоматеріалу;

- впровадження в практичну діяльність закладів охорони здоров'я регламентів EUCAST щодо визначення чутливості до антибіотиків та інтерпретації результатів з метою застосування препаратів вузького спектра дії;

- дозорного нагляду за АБР з використанням електронної бази даних (WHONET);

- адекватного часу початку, тривалості антимікробної терапії;

- раннього доступу до нових ефективних антибактеріальних лікарських засобів для пацієнтів з інфекційними захворюваннями у випадку полірезистентності;

- використання фармакокінетично/фармакодинамічної моделі антибіотикотерапії, у тому числі при проведенні одноразової хірургічної профілактики та превентивної антибіотикотерапії;

5) суворий контроль за відпуском антибіотиків в аптеках за рецептом; 
6) терапевтичний моніторинг ефективності антибактеріальних лікарських засобів;

7) застосування генеричних препаратів лише за результатами їх біоеквівалентності.

Учасники Конгресу прийняли рішення звернутись:

1) до Кабінету Міністрів України з проханням:

- підтримати підготовлений Міністерством охорони здоров'я України проект розпорядження «Про затвердження Національного плану дій боротьби зі стійкістю до протимікробних препаратів» та терміново його впровадити;

- створити державний фонд фінансування на конкурсній основі інноваційних розробок, у тому числі молодих вчених, для підтримки наукових та освітніх, у тому числі спільних, міжвідомчих проектів з управління АБР;

- стимулювати інвестування в розробку та дослідження медичних виробів для експрес-діагностики in vitro та в розробку пілотних моделей виведення на ринок нових антибіотиків, які не передбачають взаємозв'язку між отриманням прибутку та обсягами продажу;

2) до Міністерства охорони здоров'я України, Міністерства аграрної політики та продовольства України, Міністерства інформаційної політики України, Національної академії медичних наук України, Національної академії аграрних наук України з проханням:

- посилити інформаційно-просвітницьку кампанію з метою поглиблення розуміння у суспільстві ролі антибіотиків, їх цінності для охорони здоров'я, критичної необхідності їх належного використання;

- забезпечити створення посібників у різних форматах для певних груп (студенти закладів вищої медичної, фармацевтичної та ветеринарної освіти, медичні працівники, пацієнти тощо) 3 проблем управління АБР;

- активізувати підготовку фахівців охорони здоров'я та партнерів у галузі боротьби з АБР із використанням сучасних освітніх, у тому числі онлайн-ресурсів (лекцій, семінарів, майстер-класів, тренінгових лабораторних центрів тощо);

3) до Міністерства охорони здоров'я України:

- розробити національні настанови з управління АБР, національну програму та алгоритми моніторингу поширення штамів, резистентних до дії антибактеріальних препаратів;

- створити національну референс-лабораторію з дослідження чутливості мікроорганізмів до антимікробних препаратів та забезпечити іiі сучасним обладнанням і витратними матеріалами;

- забезпечити оснащення лабораторних підрозділів закладів охорони здоров'я сучасним лабораторним обладнанням, яке дозволяє в найкоротші терміни визначити збудника i його чутливість до антибактеріальних засобів та безперебійне постачання їх витратними матеріалами гарантованої якості;

- створити репозитарій даних мікробіологічних досліджень з різних географічних регіонів України, закладів охорони здоров'я тощо;

- забезпечити регулярний моніторинг належної практики фахівців охорони здоров'я (лікарів, епідеміологів, мікробіологів, провізорів, фармацевтів) з раціонального використання антибіотиків;

- посилити наукові дослідження: фундаментальні для визначення механізмів формування АБР; прикладні з виявлення нових маркерів АБР, оцінки ефективності та безпечності антибактеріальної, у тому числі комбінованої, терапії тощо.

4) до Української асоціації за доцільне використання антибіотиків, Національної лікарської ради України:

- продовжити діяльність з об'єднання зусиль науковців і фахівців різних галузей медицини, ветеринарії тощо, забезпечивши широкий обмін новою інформацією з питань АБР, отриманою на засадах доказової медицини, з використанням міжнародних підходів до визначення та інтерпретації результатів чутливості. 


\section{Accreditation Council" for Continuing Medical Education}

\section{Пост-реліз \\ 11 грудня 2018 року відбулася зустріч з президентом Акредитаційної ради безперервної медичної освіти США Гремом Макманом}

У рамках запровадження системи безперервного професійного розвитку, відповідно до постанови Кабінету Міністрів України від 28.03.2018 року №302 «Про затвердження положення про систему безперервного професійного розвитку фахівців у сфері охорони здоров'я», Група компаній «МедЕксперт» запросила до України для обміну досвідом президента Американської акредитаційної ради безперервної медичної освіти (ACCME) доктора Грема Макмана.

Система безперервної медичної освіти США вважається найбільш досконалою недержавною системою у світі. Головними напрямками діяльності ACCME є визначення, розробка та впровадження стандартів безперервної медичної освіти, яка використовується лікарями для підвищення їх компетенції з метою покращення якості надання медичної допомоги пацієнтам. АCСМЕ здійснює акредитацію провайдерів/організаторів безперервної медичної освіти за стандартами США, а також на міжнародному рівні, створюючи структуру, яка підтримує, надихає і мотивує лікарів у всьому світі повністю реалізувати свій освітній потенціал. Міжнародні кредити AMA PRA, які отримують лікарі на навчальних заходах, акредитованих АССМЕ, підтверджують якість післядипломного навчання та визнаються у всьому світі.

Українські спеціалісти мали унікальну можливість отримати інформацію 3 перших вуст та безпосередньо взяти участь у процесі реформування післядипломного професійного розвитку лікарів України.

11 грудня 2018 року у місті Києві на семінарі Групи компаній «МедЕксперт» - «Раціональна фармакологія у педіатрії при коморбідних станах», акредитованому за стандартами ACCME, відбулася зустріч доктора Грема Макмана $з$ практикуючими спеціалістами.

Він відмітив, що у процесі запровадження безперервної медичної освіти та безперервного професійного розвитку лікаря в Україні існують такі самі проблеми, які були в США, та розповів, як медична спільнота США, починаючи з 1981 року, почала створення масштаб-

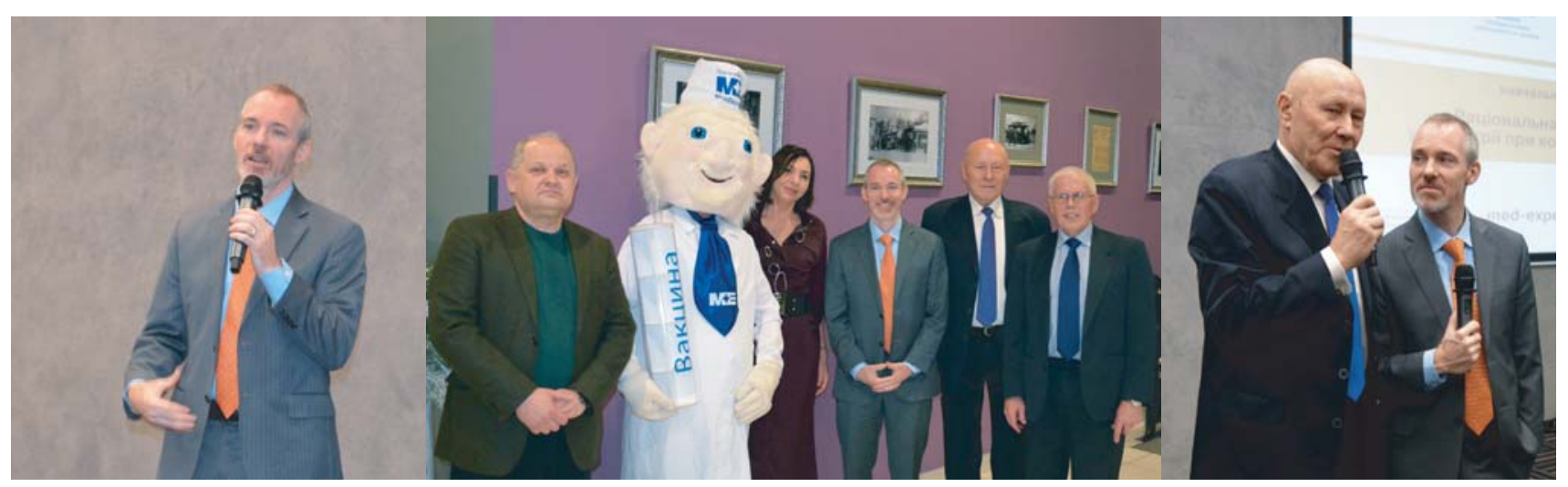




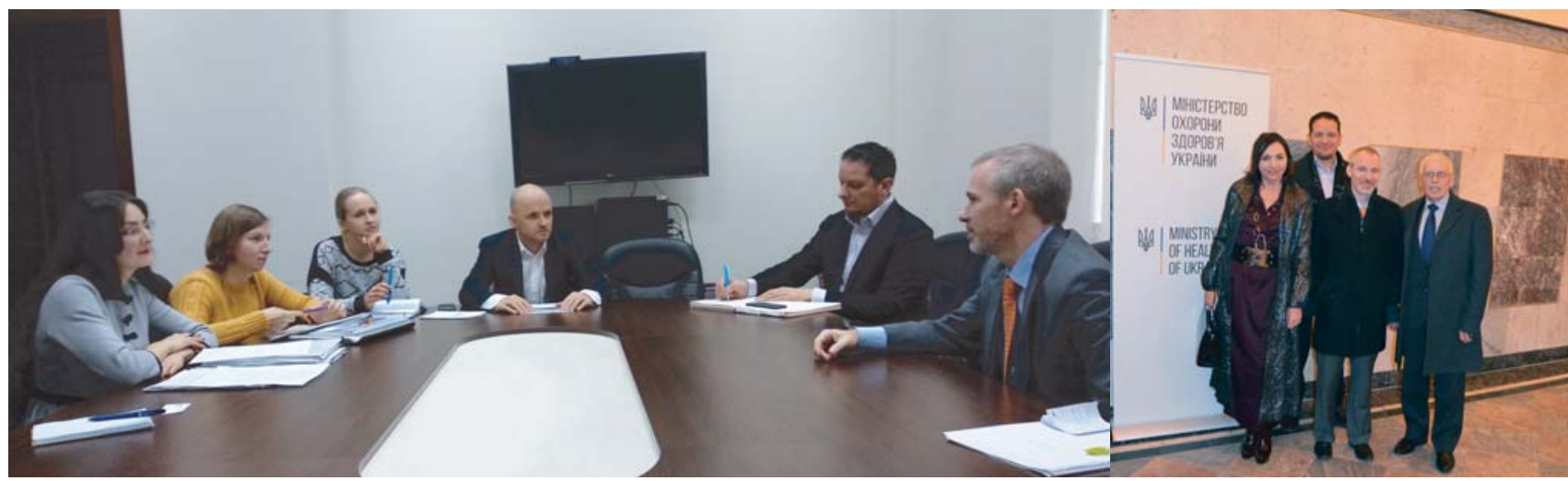

ної недержавної акредитаційної ради безперервної медичної освіти - АССМЕ. Міністерство охорони здоров'я і соціальних служб США не впливає на процес безперервної медичної освіти та ліцензування лікарів. Медична спільнота сама дбає про себе, створивши ACCME, яка повністю супроводжує процес акредитації, сертифікації та ліцензування безперервної медичної освіти. Вони роблять це на найвищому рівні, тому держава взагалі не втручається у процес. Безперервна медична освіта є обов'язковою умовою ліцензування. Доктор Макман поділився з українською медичною спільнотою досвідом АССМЕ, який вони накопичували майже 40 років, щоб допомогти нам скороти період реформування та становлення нової системи безперервної медичної освіти. Він розповів, що вони вже акредитували майже 1800 організацій, серед яких лікарні, медичні спільноти, незалежні провайдери в усьому світі (майже 700 провайдерів), медичні видання та інші заінтересовані організації. Якщо ці організації виконують правила АCCME, то у процесі своєї освітньої діяльності вони можу надавати кредити, які лікарі можуть у подальшому використовувати при отриманні та подовженні ліцензії. Доктор Макман наголосив, що в умовах технічного прогресу найважливішою є наявність різних видів навчання - лекції, майстеркласи, симуляційні тренінги, навчання у невеликих групах, он-лайн навчання, інтерактивні ігри тощо. Це допомагає задовольнити потреби лікаря в освіті, спростити доступ до навчальних матеріалів і, як наслідок, забезпечити постійне підвищення його компетенції.
У рамках свого візиту доктор Макман зустрівся з представниками МОЗ України, у тому числі з Олександром Лінчевським - заступником в.о. міністра охорони здоров'я. На зустрічі обговорювали основні шляхи подальшого розвитку системи безперервної медичної освіти України за міжнародними стандартами:

- наявність незалежного акредитатора;

- запровадження кредитної системи;

- дієва система підрахунку кредитів;

- управління комерційною незалежністю освіти;

- наявність акредитованих провайдерів, які забезпечують стандартизоване безперервне медичне навчання;

- лічензування.

Також президент Американської акредитаційної ради з безперервної медичної освіти відвідав Національну медичну академію післядипломної освіти імені П.Л Шупика. Під час спілкування зі своїми колегами Грем Макман наголосив, що безперервна медична освіта повинна відповідати стандартам:

- лікарі мають отримувати збалансовану освіту, яка грунтується на засадах доказової медицини;

- інформащія має задовольняти реальні освітні потреби лікаря;

- навчальний процес має бути вільним від комериійного впливу;

- лікарі повинні проходити перевірку отри маних/засвоєних знань та мати можливість оцінити якість, актуальність та практичність отриманих знань;

- безперервна професійна освіти повинна підтримуватись та заохочуватись роботодавцем. 

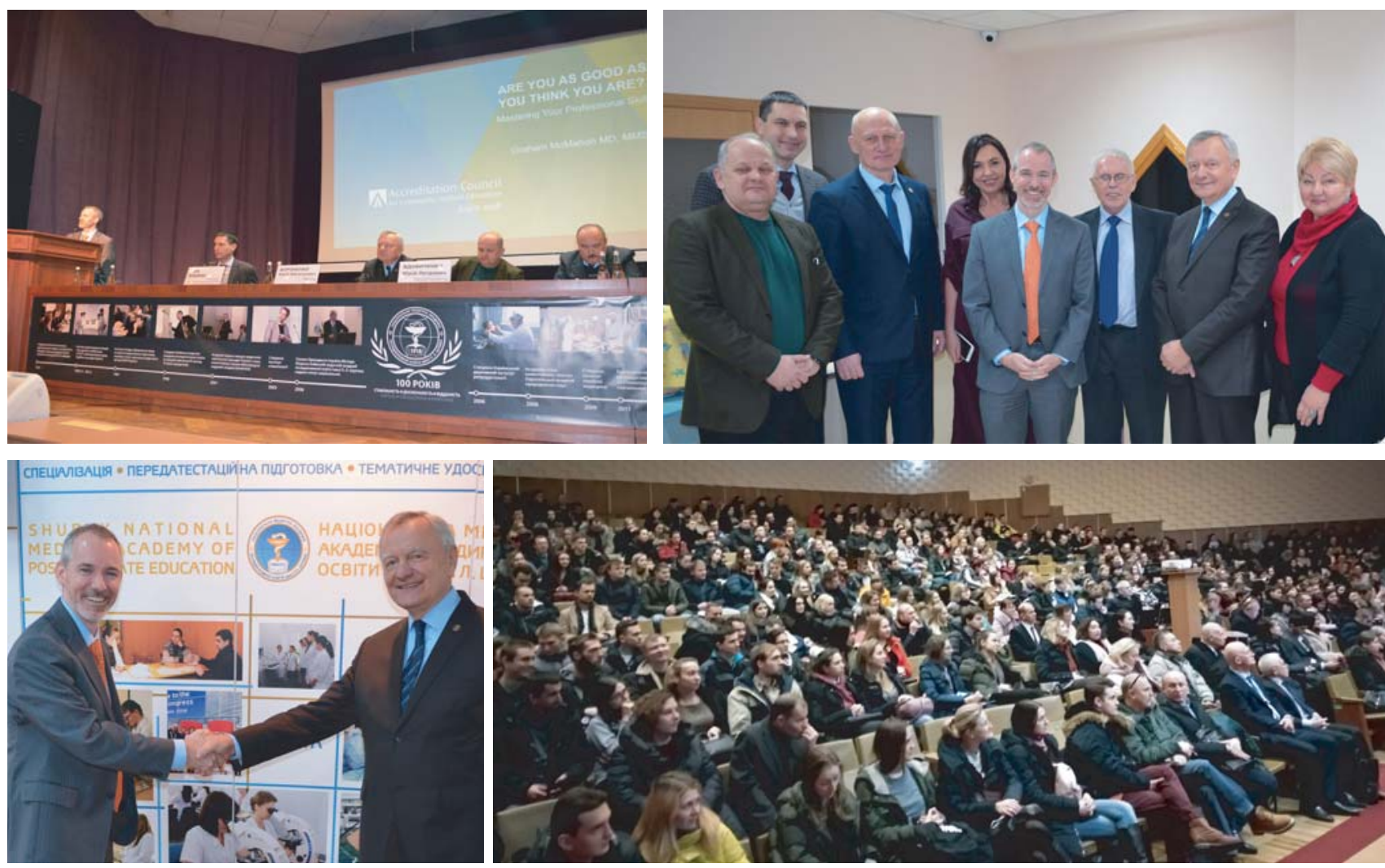

Під час зустрічі з ректором НМАПО імені П.Л. Шупика Юрієм Вороненком Грем Макман висловив надію на те, що подальше реформування медичної освіти в Україні буде поєднувати в собі як світовий досвід, так і національні особливості.

Також відбулась консультативна зустріч 3 керівництвом Всеукраїнської спілки безперервної медичної освіти, учасники якої отримали велику кількість корисної інформації та мотивацію до подальшого розвитку і стимулювання реформування безперервної медичної освіти України відповідно до міжнародних стандартів.

Американська модель безперервної медичної освіти зацікавила представників МОЗ та організаторів післядипломної освіти. Яскравий приклад реалізації такої моделі вже запроваджує в Україні перший акредитований організатор безперервної медичної освіти - Група компаній МедЕксперт. Грем Макман був вражений українською гостинністю та готовністю МОЗ України, організаторів безперервного медичного навчання та українських лікарів брати участь у процесі реформування і приєднання до міжнародної медичної спільноти та підтвердив готовність подальшої підтримки розвитку процесу становлення безперервної медичної освіти в Україні. Розпочато консультаційний процес між АССМЕ та МОЗ України для подальшого обміну досвідом.

Група компаній МедЕксперт висловлює подяку представникам МОЗ України та НМАПО імені П.Л. Шупика за підтримку та активну позицію у процесі реформування безперервної медичної освіти. Наша спільна мета - через постійний професійний розвиток та самовдосконалення лікарів покращити якість надання медичної допомоги населенню України. 


\title{
Г.В. Бекетова', К.Б. Савінова', О.Д. Дубогай², Г.Д. Міщерська' Вплив здоров'язберігаючих технологій на стан здоров'я дітей молодшого шкільного віку
}

\author{
${ }^{1}$ Національна медична академія післядипломної освіти імені П.Л. Шупика, м. Київ, Україна \\ ${ }^{2}$ Національний педагогічний університет імені М.П. Драгоманова, м. Київ, Україна \\ ${ }^{3}$ КЗ КОР «Київська обласна дитяча лікарня», м. Боярка, Україна
}

SOVREMENNAYA PEDIATRIYA.2018.8(96):17-21; doi 10.15574/SP.2018.96.17

\begin{abstract}
У сучасних умовах спостерігається тенденція до збільшення показників захворюваності серед дітей, особливо після їх вступу до школи, що обумовлює необхідність впровадження здоров'язберігаючих технологій (З3Т).

Мета: оцінити вплив 33Т «Навчання у русі» О.Д. Дубогай на стан здоров'я та адаптаційні можливості дітей молодшого шкільного віку.

Матеріали і методи. Проведене поглиблене клініко-інструментальне обстеження 153 дітей молодшого шкільного віку перед початком (2013 р.) і протягом навчання (2013-2018рр.) у середній школі №287 м. Києва (n=65, основна група), де впроваджена 33Т «Навчання у русі», і в середній школі №3 м. Боярка Київської області, де З3Т не застосовували (n=88, група контролю).

Результати. Після впровадження 33Т в основній групі відзначений достовірний приріст кількості дітей з гармонійним фізичним розвитком на 36\%, а в учнів групи контролю змін у фізичному розвитку практично не відбулося (38,6\% в першому та $41,7 \%$ у п'ятому класі). Під впливом 33 Т покращились показники функціонального стану серцево-судинної системи (ССС) - достовірно зросла кількість учнів із задовільними адаптаційнорезервними її можливостями за індексом Баєвського (97,2\% проти 33,3\% в групі контролю після закінчення початкової школи). Високий та вище середнього рівень функціонального резерву серця (за даними проби Руф'є) після закінчення початкової школи мали 77,6\% учнів основної групи і лише 8,4\% в групі контролю. Зросли також функціональні резерви дихальної системи - при застосуванні З3Т кількість учнів основної групи із задовільними результатами проби Штанге зросла з 67\% до 87\%, а в групі контролю - знизилась 3 62,5\% до 24,5\%. Пробу Генче наприкінці навчання в початковій школі задовільно виконували $100 \%$ дітей основної групи, а в групі порівняння - 76,5\%. Покращилась протиінфрекційна резистентність школярів основної групи - у четвертому класі кількість пропущених днів навчання за рік на одного учня становила 15,9, а в контролі 53,9 дня. В основній групі не відмічалось приросту частки дітей із хронічною патологією, достовірно знизилась питома вага учнів із функціональними розладами ССС з 30,8\% до 8,3\%.
\end{abstract}

Висновки. Використання З3Т «Навчання у русі» достовірно покращує функціональний стан серцево-судинної та дихальної систем у молодших школярів, опірність інфекціям, що дозволяє рекомендувати методику для широкого впровадження.

Ключові слова: діти, молодший шкільний вік, стан здоров'я, адаптаційно-резервні можливості, здоров'язберігаюча технологія.

\section{The influence of the health saving technologies on the health of the children of the primary-school age}

H.V.Beketova', K.B.Savinova', O.D. Dybohay' ${ }^{2}$, H.D. Mishcherska ${ }^{3}$

${ }^{1}$ Shupyk National Medical Academy of Postgraduate Education, Kyiv, Ukraine

${ }^{2}$ Dragomanov National Pedagogical University, Kyiv, Ukraine

${ }^{3}$ Kyiv Regional Children's Hospital, Boiarka, Ukraine

Due to modern conditions the tendency of the increasing of the morbidity among the children of the pre-schooling age is observed that causes the implementation of the health saving technologies (HST).

Aim. Estimate the influence of the HST «Education in moving» by Ph. O.D. Dybohay on the health and adoption abilities of the children of the primary-school age. Materials and methods of scrutiny. The deep clinical-instrumental examination of 153 primary-school age children was held at the beginning (2013) and during the studying process(2013-2018) in the middle school No. $287 \mathrm{Kiev}$ ( $\mathrm{n}=65$, main group), where HST «Education in moving» were implemented and in the middle school No. 3 Boiarka, Kiev region, where HST were not used ( $n=88$, control group).

Results. Having implemented the HST «Education in moving» in main group proved increasing of the amount of the children with harmonical physical fitness in $36 \%$, and changes in the physical fitness among children of the control group were slightly observed ( from $38.6 \%$ to $41.7 \%$ at the fifth form). The indices of the functional state of the cardiovascular system (CVS) were improved under the influence of the HST, the amount of the children with satisfied adoptionalreserved abilities by the Baevski's index was positively grown ( $97.2 \%$ against $33.3 \%$ in the group of control after graduation of the primary school). $77.6 \%$ of the children in the main group had the high and above the average level of the heart functional reserve ( by the data of the Rufe's test) and only $8.4 \%$ of the control group had the same result. Also the functional reserve of the respiratory system was grown among children in main group-using of the HST the amount of the children with satisfied results Shanhe's test increased from $67 \%$ to $87 \%$, and in control group decreased from $62.5 \%$ to $24.5 \%$. Hench's test was done successfully by the $100 \%$ of children in the main group at the end of the academic year, while in control group only $76.5 \%$. The communicable resistance was improved among children of the main group- the amount of the missed days in the year by the one pupil was 15.9, while in the control group was 53.9 days. The growth of the children with chronic pathology was not noticed in the main group, the proportion of students with the functional disorders of the cardiovascular system was positively reduced from $30.8 \%$ to $8.3 \%$.

Conclusion. The usage of the HST «Education in moving» improves the functional state of communicable, cardiovascular system and respiratory system among children in primary school that allows to recommend it for the wide usage.

Key words: health saving technologies, primary school age children, adoptional-reserved abilities, functional state.

\section{Влияние здоровьесохраняющих технологий на состояние здоровья детей младшего школьного возраста А.В. Бекетова', К.Б. Савинова', А.Д. Дубогай' , Г.Д. Мищерская ${ }^{3}$ \\ ${ }^{1}$ Национальная медицинская академия последипломного образования имени П.Л. Шупика, г. Киев, Украина ${ }^{2}$ Национальный педагогический университет имени М.П. Драгоманова, г. Киев, Украина \\ 3КУ KOC «Киевская областная детская больница», г. Боярка, Украина}

В современных условиях наблюдается тенденция к увеличению показателей заболеваемости среди детей, особенно после их поступления в школу, что обуславливает необходимость внедрения здоровьесохраняющих технологий (ЗСТ).

Цель: оценить влияние ЗСТ «Обучение в движении» А.Д. Дубогай на состояние здоровья и адаптационные возможности детей младшего школьного возраста. 
Материалы и методы. Проведено углубленное клинико-инструментальное обследование 153 детей младшего школьного возраста перед началом (2013 г.) и в течение обучения (2013-2018 гг.) в средней школе №287 г. Киева ( $\mathrm{n=65}$, основная группа), где внедрена 3СТ «0бучение в движении», и в средней школе №3 г. Боярка Киевской области, де ЗСТ не применяли ( $\mathrm{n}=88$, группа контроля).

Результаты. После внедрения ЗСТ «Обучение в движении» в основной группе отмечен достоверный прирост количества детей с гармоничным физическим развитием на $36 \%$, а у учеников группы контроля изменений в фризическом развитии почти не было (38,6\% в первом и 41,7\% в пятом классе). Под влиянием ЗСТ улучшились показатели функционального состояния сердечно-сосудистой системы (ССС) - достоверно увеличилось количество учеников с удовлетворительными адаптационно-резервными ее возможностями согласно индексу Баевского (97,2\% против 33,3\% в группе контроля по окончании начальной школы). Высокий и выше среднего уровень функционального резерва сердца (по данным пробы Руфьє) по окончании начальной школы имели 77,6\% учеников основной группы и только 8,4\% в группе контроля. Возросли также функциональные резервы дыхательной системы - при применении ЗСТ количество учеников с удовлетворительными результатами пробы Штанге в0зросло с 67\% до 87\%, а в группе контроля - снизилось с 62,5\% до 24,5\%. Пробу Генче в конце обучения в начальной школе удовлетворительно выполняли 100\% детей, а в группе сравнения - 76,5\%. В основной группе существенно возросло количество детей с высоким жизненным индексом (с 58,5\% до 97,2\%), а в группе контроля этот показатель снизился (с 27,3\% до 16,7\%). Улучшилась противоинфекционная резистентность школьников основной группь в четвертом классе количество пропущенных дней обучения за год на одного ученика составило 15,9, а в контроле - 53,9 дня. В основной группе не отмечалось прироста доли детей с хронической патологией, достоверно снизился удельный вес учеников с функциональными расстройствами ССС с $30,8 \%$ до $8,3 \%$

Выводы. Использование ЗСТ «Обучение в движении» достоверно улучшает функциональное состояние сердечно-сосудистой и дыхательной систем у учеников начальной школы, сопротивляемость инфекциям, что позволяет рекомендовать методику для широкого внедрения.

Ключевые слова: дети, младший школьный возраст, состояние здоровья, адаптационно-резервные возможности, здоровьесохраняющая технология.

\section{Вступ}

$\mathrm{H}$ а сьогодні проблема оздоровлення дітей шкільного віку із суто медичної переросла у значущу соціальну [1,6,7]. Традиційна організація навчального процесу створює у школярів постійні психологічні та емоційні перевантаження, що порушують процеси саморегуляції фізіологічних функцій i сприяють розвитку функціональних розладів, а в подальшому - і хронічних захворювань[8]. Численні наукові дослідження підтверджують той факт, що діти при вступі до школи вже мають певні проблеми зі здоров'ям [7,8]. Дослідження, проведене в ДУ «ІПАГ імені академіка О.М. Лук'янової НАМН України», зафіксувало порушення стану здоров'я у близько 70\% дітей при вступі до школи, а у 30\% виявлені хронічні захворювання [5].

Тенденція до погіршення стану здоров'я школярів за роки навчання в школі диктує необхідність пошуку ефективних реабілітаційних заходів. У зв'язку с цим активно розробляються здоров'язберігаючі технології (33Т), з впровадженням яких зберігається той рівень здоров'я, 3 яким дитина прийшла до школи. Кожен елемент 33Т спрямований на попередження формування хронічної патологіi, стабілізацію емоційно-вольової сфери i, як наслідок, покращення засвоювання шкільного матеріалу та профілактику шкільної дезадаптації [2]. Іще одним важливим фактором використання 33Т є реальна можливість масового охоплення школярів при мінімальних матеріальних витратах та за активної участі батьків. Одним із найкращих прикладів застосування 33Т може буде авторська методика «Навчання у русі» для дітей дошкільних та шкільних навчальних закладів, розроблена професором О.Д. Дубогай [4], яка має на меті нівелювати розрив між фізичними вихованням та іншими видами навчальної діяльності, створення реальних механізмів, що обумовлюють взаємозв'язок між пізнавальною та руховою активністю та збереження здоров'я школярів. Згідно з положеннями 33Т, у навчальний процес впроваджено надання нового матеріалу у формі дидактичної гри, яка супроводжується руховою активністю. Передача знань під час дидактичної гри включає у роботу не тільки усвідомлене запам'ятовування, але й асоціативне мислення, яке посилюється руховими та ментальними процесами. Створюється ефективна освітньо-оздоровча система, спрямована на відновлення рухової активності, інтенсивність якої у школярів знижується втричі порівняно $з$ дошкільним періодом [2]. Таким чином, досягаються дві мети: збереження здоров'я і покращення засвоєння нового матеріалу.

Запроваджена 33Т відповідає вимогам концепції системи профілактики ранніх порушень стану здоров'я та підвищення адаптаційнорезервних можливостей у дітей шкільного віку, яка свого часу була запропонована відомим вітчизняним вченим, академіком О.М. Лук'яновою (2003).

Організація оптимального рухового режиму в навчальних закладах є особливо актуальною у світлі Указу Президента України «Про Національну стратегію 3 оздоровчої рухової активності в Україні на період до 2025 року «Рухова активність - здоровий спосіб життя здорова нація» від 09.02.16р. Метою Національної стратегії є формування в суспільстві умов щодо оздоровчої рухової активності та здорового способу життя для формування здо- 
ров'я громадян як найвищої соціальної цінності у державі.

Mema роботи: оцінити вплив 33Т «Навчання у русі» на стан здоров'я школярів молодшого шкільного віку.

\section{Матеріал і методи дослідження}

Робота виконана в загальноосвітній школі (ЗОШ) №287 Святошинського району м. Києва, ЗОШ №3 м. Боярка Київської області та у комунальному закладі КОР «Київська обласна дитяча лікарня». Було проведено поглиблене клініко-інструментальне обстеження 153 дітей молодшого шкільного віку перед початком та протягом навчання у початковій школі.

У початкових класах ЗОШ №287 м. Києва, де впроваджена 33Т, було обстежено 65 школярів, які склали основну групу. До групи контролю увійшли 88 учнів початкової ЗОШ №3 м. Боярка Київської області, які навчалися за загальноприйнятими методиками.

Обстеження школярів включало оцінку антропометричних показників відповідно до наказу МОЗ України №802 від 13.09.2013 р. «Критерії оцінки фізичного розвитку дітей шкільного віку», лабораторні та інструментальні методи дослідження. Стан протиінфекційної резистентності визначали за частотою епізодів гострих респіраторних інфекцій (ГРІ) протягом року, наявністю їх ускладнень та кількістю днів пропущених занять у школі за рік. Також з'ясовували частоту функціональних і хронічних соматичних захворювань. Для визначення стану здоров'я обстежених дітей був проведений огляд спеціалістами.

Дослідження виконані відповідно до принципів Гельсінської Декларації. Протокол дослідження ухвалений Локальним етичним комітетом (ЛЕК) усіх зазначених у роботі установ. На проведення досліджень було отримано поінформовану згоду батьків дітей (або їхніх опікунів).

\section{Результати дослідження та їх обговорення}

Наше дослідження підтверджує той факт, що діти при вступі до школи вже мають порушення здоров'я. В обох групах виявлено велику кількість дітей з дисгармонійним фізичним розвитком (35,0\% в основній групі та 49,0\% у групі контролю). Дисгармонійність передусім була обумовлена надлишковою вагою та ожирінням (80,0\% від усіх дітей з дисгармонійним фізичним розвитком в основній і $75,0 \%$ в групі контролю). Вивчення резервів серцево-судинної системи (ССC) у першокласників показало напруження механізмів адаптації (на підставі індексу Баєвського) у 73,8\% обстежених в основній групі та 81,8\% у групі контролю. Хронічні захворювання та функціональні розлади виявлені у $61(93,8 \%)$ дитини основної та у $75(85,3 \%)$ групи контролю $(\mathrm{p}<0,05)$. Лише 4 $(6,2 \%)$ дитини 3 основної групи та 13 (14,7\%) 3 групи контрою були практично здоровими $(\mathrm{p}<0,05)$.

Оскільки серед першокласників переважали діти 6-річного віку, було проведено порівняльний аналіз функціональної зрілості дітей 6- та 7-річного віку. У переважної більшості 6-річних дітей виявлено напруження адаптаційно-резервних можливостей ССС. При виконанні проби Руф'є в основній групі високий та вищий за середній рівень спостерігався лише у 25,5\% школярів 6-річного віку, а серед 7 -річних цей показник становив $31,8 \%$. Серед 6-річних дітей пробу Шалкова в основній групі виконували задовільно 37,9\% учнів, тоді як серед 7-річних $-50,0 \%(\mathrm{p}<0,05)$.

Таким чином, серед обстежених першокласників діти 6-річного віку, внаслідок функціональної незрілості, більш уразливі до зриву адаптаційних процесів та розвитку шкільної дезадаптації.

На другому етапі (2014-2017 pр.) комплексно обстежені 153 учні обох груп спостереження протягом навчання у початковій школі. У ході основного дослідження в групі порівняння за роки навчання в початковій школі виявлено достовірне погіршання стану здоров'я школярів групи порівняння, що свідчить про наявність так званого «шкільного фактору» [8]. Так, за роки навчання серед дітей групи порівняння виявлено достовірне зростання питомої ваги дітей з ожирінням та надлишковою масою тіла ( $333,5 \%$ до $50,0 \%, p<0,05$ ), зниження частки школярів із задовільними адаптаційно-резервними можливостями з 82,9\% до 33,3\%.

Встановлено, що впровадження З3Т сприяе формуванню гармонійного фізичного розвитку школярів, підтримує його в процесі навчання та обумовлює можливість поліпшення. Так, за роки навчання серед учнів, що займалися за системою 33Т, питома вага дітей з гармонійним фізичним розвитком збільшилася 3 27,7\% до $63,9 \%(\mathrm{p}<0,05)$. Водночас в учнів групи контролю змін у фізичному розвитку майже не відбулося (38,6\% у першому класі та 41,7\% у п'ятому). При цьому серед них достовірно зросла частка 
дітей з надлишковою масою тіла та ожирінням (з 33,4\% до 50,0\%). Серед школярів, що навчалися за допомогою ЗЗТ «Навчання у русі», навпаки, відмічалася тенденція до зниження частки дітей з ожирінням та надмірною вагою (з 20,0\% до 16,7\%).

Відзначено, що З3Т сприяє підвищенню адаптаційно-резервних можливостей дитячого організму та позитивно впливає на функціональний стан ССС. В основній групі достовірно зросла кількість дітей із задовільними адаптаційно-резервними можливостями ССС за індексом Баєвського (97,2\% учнів), тоді як у групі контролю на момент закінчення початкової школи таких дітей було лише 33,3\% $(\mathrm{p}<0,001)$. Високий та вищий від середнього рівень функціонального резерву серця (за даними проби Руф'є) після закінчення початкової школи мали $77,6 \%$ учнів основної групи та лише 8,4\% групи контролю ( $<<0,05)$.

В основній групі при проведенні кліноортостатичної проби спостерігалось достовірне збільшення частки дітей з фізіологічною реакцією гемодинаміки при зміні положення тіла (з 64,6\% до 100,0\%), а в контрольній групі таких дітей було 65,9\% на початку навчання і 44,4\% після його закінчення.

На тлі застосування 33Т достовірно збільшилася кількість учнів із задовільним показником екскурсії грудної клітки - з 41,5\% до 88,9\% $(\mathrm{p}<0,05)$. Перед початком навчання в обох групах виявлено зниження стійкості дітей до гіпоксіі за результатами проб Штанге та Генче. В основній групі кількість дітей із задовільними результатами проби Штанге зросла з 67,0\% до $87,0 \%$, тоді як у групі порівняння - знизилась з 62,5\% до 24,5\% (p<0,05). Пробу Генче наприкінці навчання у початковій школі задовільно виконували $100,0 \%$ учнів основної групи та тільки 76,5\% контрольної $(\mathrm{p}<0,05)$. Отже, запропонована методика позитивно впливає на функціональний стан дихальної системи у дітей молодшого шкільного віку.

Проведене дослідження стану протиінфекційної резистентності. Відсутність дитини в школі через хворобу може знижувати іiі шкільну успішність, а при значній кількості пропусків призвести до шкільної дезадаптації. У ході застосування 3ЗТ учні достовірно рідше пропускали заняття внаслідок хвороби. Так, у четвертому класі середній показник пропущених днів навчання за рік на одного учня основної групи склав 15,9, тоді як серед учнів кон- трольної цей показник становив 53,9 дня $(\mathrm{p}<0,05)$. Аналогічна тенденція була й щодо рекурентних (4 і більше епізодів за рік) респіраторних захворювань. В основній групі їх кількість знизилася з 5,0\% до 2,5\%, тоді як у контрольній групі він був утричі вищим (7,5\% наприкінці навчання в початковій школі). При цьому в основній групі у чотири рази знизилася кількість ускладнених форм захворювання (з 15,0\% до 3,5\%), а у групі контролю показник залишався стабільно високим $(15,0 \%-16,0 \%, \mathrm{p}<0,05)$.

За останній рік навчання у початковій школі $17,0 \%$ учнів основної групи жодного разу не хворіли, у той час як серед дітей контрольної групи частка таких дітей знизилася 3 13,0\% до 5,0\%. Отже, в основній групі не тільки була нижчою захворюваність на ГРІ, але і їх перебіг був більш сприятливим, що свідчить про досить високий рівень протиінфекційного захисту та високі резервні можливості учнів.

У результаті дослідження було з'ясовано, що при вступі до школи більшість дітей мали хронічні захворювання та функціональні розлади за рахунок порушень з боку опорно-рухового апарату (30,8\% в основній групі і 29,5\% у групі контролю), органів зору (18,5\% і 17,0\%), ССС (30,8\% та $46,6 \%)$, хвороб органів дихання (35,4\% і 7,9\%) та ендокринної системи (20,0\% і 32,9\% відповідно).

У ході 4-річного спостереження за дітьми було доведено, що використання 33Т має позитивний вплив на їх патологічну ураженість. В основній групі майже не відмічалось приросту частки дітей 3 хронічною патологією, достовірно знизилась питома вага дітей з функціональними розладами ССС - з 30,8\% до 8,3\% $(\mathrm{p}<0,05)$, тоді як в групі контролю зафіксований достовірний приріст частки учнів із порушеннями опорного-рухового апарату - $329,5 \%$ до 44,4\% (p<0,05), хворобами органів травлення $-321,9 \%$ до $36,0 \%(\mathrm{p}<0,05)$, органів дихання - 3 7,9\% до 44,4\% (p<0,05), ендокринними хворобами -3 32,5\% до 50,0\% (p<0,05). Достовірно збільшилась у групі контролю кількість дітей із функціональними розладами ССС, що формують групу ризику щодо розвитку хронічної патології (з 46,6\% до 58,3\%, p<0,05).

\section{Висновки}

Таким чином, проведені дослідження дозволили розробити медичну складову 33Т «Навчання у русі», довести ефективність i застосування. Показаний позитивний вплив 
33Т на функціональний стан ССС та дихальної системи за рахунок підвищення адаптаційнорезервних можливостей учнів, на протиінфекційну резистентність, на гармонійність фізичного розвитку школярів початкової школи.
Це дозволяє рекомендувати дану 33Т для широкого впровадження у загальноосвітні навчальні заклади.

Автори заявляють про відсутність конфлікту інтересів.

\section{ЛITEPATУРА}

1. Антипкін ЮГ, Волосовець ОП, Майданник ВГ та ін. (2018). Стан здоров'я дітей - майбутнє країни. Здоровье ребенка. 13; 1. http://dx.doi.org/10.22141/2224-0551.13.1.2018.127059

2. Бекетова ГВ, Савінова КБ.(2018). Вплив здоров'язберігаючих техно логій на антиінфекційну резистентність та формування хронічної патології у дітей молодшого шкільного віку. Современная педиатрия. 4(92):17-22.

3. Бойченко Т. (2005). Валеологія - мистецтво бути здоровим Здоров'я та фізична культура. 2: 1-4

4. Дубогай ОД. (2005). Навчання в русі: Здоров'язберігаючі педагогічні технології в початковій школі: метод. реком. Київ: ВД Шкільний світ: 112.
5. Лукьянова ЕМ. (2003). Медицинские и педагогические аспекты проблемы сохранения здоров'я детей. Междунар. мед. журнал. 9;3: 6-9.

6. МОЗ України, дУ УІСД МОЗ України. (2017). Щорічна доповідь про стан здоров'я населення, санітарно-епідемічну ситуацію та результати діяльності системи охорони здоров'я України. 2016 рік. Київ: 43-69.

7. Моїсеєнко РО, Дудіна ОО, Гойда НГ. (2017). Аналіз стану захворюваності та поширеності захворювань у дітей в Україні за період 2011-2015роки. Современная педиатрия. 2(82):17-27.

8. Муквіч ОМ, Камінська ТМ.(2016). Організація профілактичнореабілітаційних заходів у дітей в умовах школи. Современная педиатрия. 3(75): 129-133.

\section{Сведения об авторах:}

Бекетова Галина Владимировна - д.мед.н., проф., зав. каф. детских и подрастковых заболеваний НМАПО имени П.Л. Шупика. Адрес: г. Киев, ул. Дорожицкая, 9.

Савинова Катерина Борисовна - ассистент каф. детских и подрастковых заболеваний НМАПО имени П.Л. Шупика. Адрес: г. Киев, ул. Дорожицкая, 9.

Мищерская Галина Дмитриевна - гл. врач КЗ КОГА Киевская областная детская больница". Адрес: г. Боярка, Киево-Святошинський район, Киевская обл. ул. Крещатик, 83. Дубогай Александра Дмитриевна - д.пед.Н., проф. зав. каф. физического воспитания и здоровья Национального педагогического университета имени М.П. Драгоманова. Адрес: г. Киев, ул. Тургеневская, 3-9

Статья поступила в редакцию 13.07.2018 г., принята к печати 02.12.2018 г.

\section{ВНИМАНИЕ!}

\section{Изменения в оформлении списка литературы}

Согласно Приказу МОН Украины № 40 от 12.01.2017 г. «Об утверждении требований к оформлению диссертаций» вносятся изменения в оформление списка литературы в журнале. Теперь оформление осуществляется в соответствии со стилем APA (American Psychological Association style), используемым в диссертационных работах.

Примеры оформления литературных источников

Журнальная публикащия

Автор АА, Автор ВB, Автор СС. (2005). Название статьи. Название журнала. 10(2); 3: 49-53.

Книга

Автор АА, Автор ВВ, Автор СС. (2006). Название книги. Город: Издательство: 256.

Глава в книге

Автор АА, Автор ВВ, Автор СС. (2006). Название раздела (главы). В кн. Автор книги. Название книги. Под ред. Фамилия СС. Город: Издательство: 256.

Интернет-ресурс

Автор АА, Автор ВВ, Автор СС. (2006). Название статьи. Название журнала/книги (если есть). URL-адрес публикации.

Оформление литеры по новым требованиям повысит возможности поисковых ресурсов в интернете, и, как следствие, цитируемость авторов. 
О.І. Дорош', І.П. Цимбалюк-Волошин,', Х.І. Бодак', Р.С. Поліщук', А.І. Степанюк', O.І. Воробель', Л.Л. Скоропад', О.О. Трояновська ${ }^{1,2}$, О.І. Козлова', А.М. Мих ${ }^{1,3}$, Л.П. Середич', О.В. Глинська' Прогрес у лікуванні гострої лімфобластної лейкемії: 25 років застосування міжнародних протоколів у відділенні дитячої гематології Західноукраїнського
спеціалізованого дитячого медичного центру

'КНП ЛОР «Західноукраїнський спеціалізований дитячий медичний центр», м. Львів, Україна ${ }^{2}$ Львівський національний медичний університет імені Данила Галицького, Україна ЗМедичний центр Святої Параскеви, м. Львів, Україна

SOVREMENNAYA PEDIATRIYA.2018.8(96):22-36; doi 10.15574/SP.2018.96.22

\begin{abstract}
Проаналізовано результати лікування за модифікованими програмами хіміотерапії міжнародної групи BFM 370 хворих на гостру лімфобластну лейкемію (ГЛЛ) віком від 0 до 18 р. з лютого 1993 р. до березня 2018 р. Показник безподійного виживання (event-free survival (EFS) для усієї вибірки пацієнтів становить 73,2\%. 143 (38,65\%) пацієнти отримали лікування на основі програм ALL-BFM 90/95 (група 1); 131 (35,41\%) хворий — ALL IC-BFM'2002 (група 2); 88 (23,78\%) хворих — ALL IC-BFM 2009 (група 3). Діти віком до 1 року (8 осіб) лікувалися за програмами INTERFANT 99/06 (група 4). EFS у групі 1 становить 68,5\% із медіаною спостереження (MC) 220 місяців, за протоколом ALL IC-BFM $2002-77,6 \%$ із MC 111 місяців, у групі 3 - 85,2\% при MC 39 місяців, у групі з програмами INTERFANT 99/06 - 12,5\% із MC 13,5 місяця. EFS для пацієнтів групи середнього ризику (ГСР) у групі 1 становить $71,0 \%$, у групі $2-83,7 \%$, а у групі $3-90,6$ ( $\mathrm{p}=0,04232)$. EFS для пацієнтів з групи високого ризику (ГВР) у групі 1 становить $50,0 \%$, у групі $2-55,6 \%$, у групі $3-73,9 \%$ ( $\mathrm{p}=0,09653$ ). Кумулятивне виживання (overall survival (OS) у всій вибірці становить 78,0\%. Загалом померло 73 (18,7\%) хворих. У 32 (43,8\%) осіб смерть мала зв'язок з терапією I лінії ГЛЛ, з них 11 (34,37\%) хворих померли від токсико-септичних ускладнень до досягнення ремісії ГЛЛ під час індукційної терапії, 19 (59,37\%) дітей - від ускладнень у ремісії і на різних етапах інтенсивної хіміотерапії, 1 хворий з ГВР - від посттрансплантаційних ускладнень, 1 пацієнт — на 160 міс. після досягнення ремісії від фульмінантного перебігу вірусного гепатиту В. У 39 (53,42\%) хворих смерть настала у II гострому періоді внаслідок прогресування лейкемії та/або інфекційних ускладнень. Рецидиви ГЛЛ діагностовано у $53(16,21 \%)$ осіб. Безрецидивне виживання (disease-free survival (DFS) становить 83,2\%. Рідкісним віддаленим наслідком лікування ГЛЛ у дітей були вторинні злоякісні захворювання, які зареєстровано у 5 (1,35\%) дітей. Астроцитома, менінгіома та вторинна гостра мієлоїдна лейкемія (ГМЛ) успішно проліковані, олігодендрогліома та вторинний мієлодиспластичний синдром 3 трансформацією у ГМЛ мали летальний наслідок. Алогенну трансплантацію стовбурових гемопоетичних клітин (ало-ТСГК) виконано 15 особам. Виявлено статистично достовірне покращання показників EFS при застосуванні програмної поліхіміотерапії ALL IC-BFM 2009, найгірші результати лікування були у дітей до 1-го року $(p<0,05)$. Лікування хворих з високої групи ризику (ГВР) та дітей першого року життя потребує подальшого пошуку шляхів підвищення ефективності терапії і зниження її токсичних ефектів.
\end{abstract}

Ключові слова: гостра лімсообластна лейкемія, діти, лікування, міжнародні протоколи.

\title{
Progress in the treatment of acute lymphoblastic leukemia: 25 years of application of international protocols in the Department of Pediatric Hematology of the Western Ukrainian Specialized Children's Medical Center
}

O. Dorosh', I. Tsymbalyuk-Voloshyn'12, Kh. Bodak', R. Polishchuk', A. Stepanyuk', O. Vorobel',

L. Skoropad', O. Troyanovska' ${ }^{12}$, O. Kozlova' ${ }^{1}$, A. Myh ${ }^{1,3}$, L. Seredych' ${ }^{1}$, O. Hlynska'

'Lviv Regional Council Public Institution «Western Ukrainian Specialized Children's Medical Centre», Ukraine 'Danylo Halytskyy Lviv National Medical University, Ukraine

${ }^{3}$ Medical center of Saint Paraskevia, Lviv, Ukraine

The results of treatment for modified chemotherapy programs of the international BFM group from February 1993 to March 2018 in 370 patients with acute lymphoblastic leukemia (ALL) aged 0 to 18 years were analyzed. The event-free survival (EFS) indicator for the entire sample of patients is $73.2 \%$. $143(38.65 \%)$ patients received treatment based on programs ALL-BFM 90/95 (group 1); from November 2002 to June 2012 - 131 (35.41\%) patients ALL IC-BFM 2002 (group 2); from June 2012 - 88 (23.78\%) patients — ALLIC-BFM2009 (group 3) correspondingly. Children under the age of 1 (8 persons) from August 2008 were treated according to INTERFANT'99/06 programs (group 4). EFS in group 1 is $68.0 \%$ with a median observation time (M0) for 220 months, in group $2-77.6 \%$ with M0 111 months, in group $3-85.2 \%$ with M0 39 months, in group $4-12.5 \%$ of M0 13.5 months. The statistically significant improvement of EFS indexes in group 3, the worst results in children under 1 year $(p<0.05)$. The EFS for middle-risk group (MR) patients in the 1st group was $71.0 \%$, in the 2 nd group $-83.7 \%$, and in the 3 rd group $-90.6 \%(p=0.04232)$. The EFS for the high-risk group (HR) patients in the 1 st group was $50.0 \%$, in the $2 \mathrm{nd}-55.6 \%$ and in the 3 rd group $-73.9 \%(p=0.09653)$. The overall survival $(0 S)$ in the entire sample is $78.0 \%$. Totally 73 died $(18.7 \%)$. In $32(43.8 \%)$ people, death was associated with the therapy of the 1 st line of ALL, 11 of them (34.37\%) died of toxic-septic complications until the remission of ALL during induction therapy; 19 children $(59.37 \%)$ - from complications in 1st remission at different stages of intensive chemotherapy, 1 patient with HR from post-transplant complications, 1 patient — for 160 months. after reaching a remission from the fulminant course of viral hepatitis B. The 39 (53.42\%) patients, death occurred in the second acute period from the progression of leukemia and/or infectious complications. Relapse of ALL is diagnosed in $53(16.21 \%)$ people. Disease-free survival (DFS) is $83.2 \%$. A rare remote consequence of ALL treatment in children was secondary malignant diseases, which were registered in $5(1.35 \%)$ children. Astrocytoma, meningioma, secondary acute myeloid leukemia (AML) have been successfully treated, oligodendroglioma and secondary myelodysplastic syndrome with transformation in to AML was a reason of lethal consequence. 8 persons from the HR-group in the 1st remission had allo-BMT (abroad), including 2 patients — for whom alloBMT was a second therapeutic line for treatment of secondary AML. The statistically significant improvement in the EFS indices in the application of program polychemotherapy ALL IC-BFM 2009 was revealed, the worst results of treatment in children under 1 year $(p<0.05)$. Treatment of patients with high risk groups $(H R)$ and in children of the first year of life requires further searching for ways to improve the effectiveness of therapy, and reduce its toxic effects.

Key words: children, acute lymphoblastic leukemia, treatment, international protocols. 


\section{Прогресс в лечении острого лимфобластного лейкоза: 25 лет применения международных протоколов в отделении детской гематологии Западноукраинского специализированного детского медицинского центра

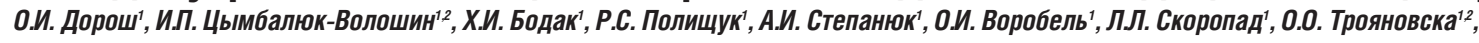 О.И. Козлова ${ }^{1}$, А.М. Мых ${ }^{1,3}$, Л.П. Середич' ${ }^{1}$ О.В. Глинска' \\ ${ }^{1}$ КНП ЛОС «Западноукраинский специализированный детский медицинский центр», (КНП ЛОС ЗУСДМЦ), г. Львов,Украина ${ }^{2}$ Львовский национальный медицинский университет имени Данила Галицкого, Украина ${ }^{3}$ Медицинский центр Святой Параскевии, г. Львов, Украина}

Проанализированы результаты лечения согласно модифицированным программам химиотерапии международной группы BFM 370 больных острым лимфобластным лейкозом (ОЛЛ) в возрасте от 0 до 18 лет с февраля 1993 г. по март 2018 г. Показатель безсобытийного выживания (еvеnt-free survival (EFS) для всей выборки пациентов составляет 73,2\%. 143 (38,65\%) пациента получали лечение по программам ALL-BFM 90/95 (группа 1); 131 (35,41\%) больной - ALL IC-BFM 2002 (группа 2); 88 (23,78\%) больных - ALL IC-BFM 2009 (группа 3). Дети в возрасте до 1 года (8 человек) лечились в соответствии с программами INTERFANT 99/06 (группа 4). EFS в группе 1 составляет 68,5\% при медиане наблюдения (МН) 220 месяцев, по протоколу ALL IC-BFM 2002 - 77,6\% при MH 111 месяцев, в группе 3 - 85,2\% при МH 39 месяцев, в группе по программам INTERFANT 99/06 — 12,5\% при MH 13,5 месяцев. EFS для пациентов группы среднего риска (ГСР) в группе 1 составляет 71,0\%, в группе 2 - 83,7\%, а в группе 3 - 90,6\% ( $p=0,04232)$. EFS для пациентов группы высокого риска (ГВР) в группе 1 составляет 50,0\%, в группе 2 - 55,6\%, в группе 3 - 73,9\% (p=0,09653). Кумулятивное выживание (overall survival (OS) по всей выборке составляет 78,0\%. Всего умерло 73 (18,7\%). у 32 (43,8\%) человек смерть связана с терапией І линии 0ЛЛ, из них 11 (34,37\%) больных умерли от токсико-септических осложнений до достижения ремиссии ОЛЛ во время индукционной терапии; 19 (59,37\%) детей — от осложнений в ремиссии I на разных этапах интенсивной химиотерапии, 1 больной гВР от посттрансплантационных осложнений, 1 пациент — на 160 мес. после достижения ремиссии - вследствие фрульминантного течения вирусного гепатита В. У 39 (53,42\%) больных смерть наступила во II остром периоде от прогрессирования лейкемии и/или инсекционных осложнений. Рецидивы ОЛЛ диагностированы у 53 (16,21\%) человек. Безрецидивная выживаемость (disease-free survival (DFS) coctaвляет 83,2\%. Редким отдаленным последствием лечения ОЛЛ у детей были вторичные злокачественные заболевания, зарегистрированные у 5 (1,35\%) детей. Астроцитома, менингиома и вторичная острая миелоидная лейкемия (ОМЛ) успешно пролечены. Олигодендроглиома и вторичный миелодиспластический синдром с трансформацией в ОМЛ завершились летальным исходом. Аллогенная трансплантация стволовых гемопоэтических клеток (алло-ТСГК) выполнена 15 больным. Определено статистически достоверное улучшение показателей ЕFS при применении программной полихимиотерапии ALL IC-BFM 2009, худшие результаты лечения наблюдались у детей до 1 года (р <0,05). Лечение больных ГВP и детей первого года жизни требует дальнейшего поиска путей повышения эффрективности терапии и снижения ее токсических эффектов. Ключевые слова: острый лимфобластный лейкоз, дети, лечение, международные протоколы.

\section{Вступ}

3 відкриттям у вересні 1990 р. відділення гематології у Львівській обласній дитячій спеціалізованій клінічній лікарні (у 2009 р. перейменована на КЗ ЛОР ЗУСДМЦ) почався новий етап в історії вітчизняної гематології. Створення такого осередку ставило завдання збільшення чисельності вилікуваних дітей 3 гематоонкологічними захворюваннями, у тому числі хворих на гостру лейкемію, що становить 30,0-35,0\% серед злоякісних новоутворень дитячого віку, з них 80,0-90,0\% припадає на гостру лімфобластну лейкемію (ГЛЛ) [5,6,46,51,68,74,77,78]. Ще чверть століття тому від лейкеміі, яка вважалася невиліковною хворобою, українці одужували в поодиноких випадках. Нині ГЛЛ належить до тих недуг, які ефективно лікують в Україні.

За результатами сучасних багатоцентрових досліджень, у 75,0-90,0\% дітей з ГЛЛ, старших 1 року, досягається п'ятирічне виживання [52,65]. Однак у близько 10,0-20,0\% пацієнтів спостерігається рецидив хвороби. Серед них лише у третини є шанси вижити протягом багатьох років [5,7,9,18,21,32,63,65]. У до 10,0\% дітей причиною смерті $є$ важкі інфекційні процеси, зумовлені агранулоцитозом, геморагічні та інші токсичні ускладнення [27].

У нашій країні з початку 90-х років минулого століття застосовується інтенсивна хіміоте- рапія, створена на основі програми ALL-BFM 90, яка сприяє значному поліпшенню результатів лікування ГЛЛ у дітей. За участі німецьких колег (професора Гюнтера Шеллонга з Університетської клініки м. Мюнстера та доктора Альфреда Рейтера з Вищої медичної школи м. Ганновера) у 1993 р. була створена Кооперативна група «Дитячі лейкеміі та лімфоми України» (ДГЛЛУ). На основі протокольного лікування ALL-BFM 90/95 впроваджено модифіковані лікувальні протоколи Групи ВFM ГЛЛ-ДГЛЛУ 93/95 із відповідною діагностикою та стратифікацією до груп ризику. Відділення гематології та інтенсивної терапії ЗУСДМЦ є активним членом кооперативної групи ДГЛЛУ з часу i․ заснування та дотримується усіх вимог стандартизованих протоколів.

Модифікація програмами ГЛЛ-ДГЛЛУ 93/95 порівняно з базовою полягала у: редукції дози метотрексату (MTX) у протоколі М до 1,0 г/ ${ }^{2}$ замість 5,0 г/м²; у програмі ГЛЛ-ДГЛУ 95 діти групи низького ризику (ГНР) отримували лікування за протоколом Іа, коли застосовувалися лише два введення даунорубіцину. Загальний дизайн програм представлений на рис.1. Усіх хворих розділяли на 3 групи ризику: низький (ГНР), середній (ГСР) і високий (ГВР). У ГВР проводилося лікування відповідно до терапевтичного плану для хворих 


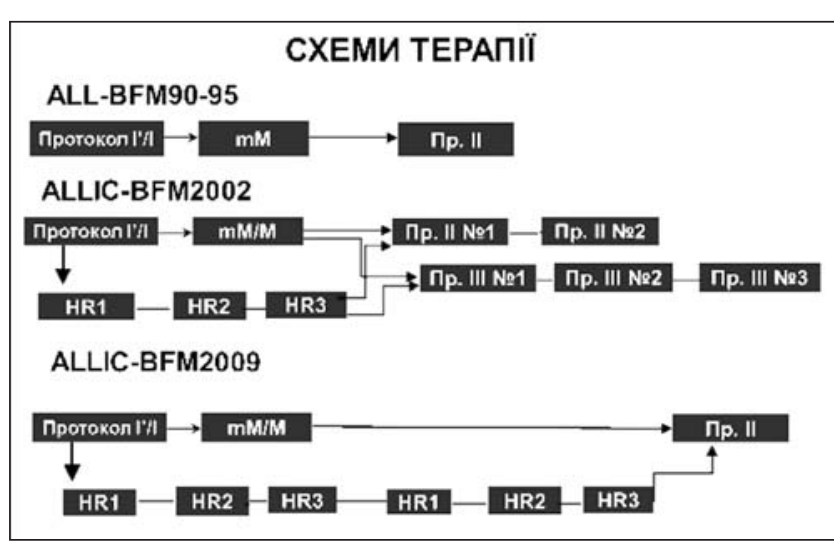

Pис.1. Схематичне зображення інтенсивної фрази протокольної терапії дітей, хворих на ГЛЛ, за стандартними програмами групи BFM

групи середнього ризику (ГСР). До ГНР віднесено дітей віком від 1 року до 6 років з рівнем лейкоцитів менше 20,0 Г/л, абсолютною кількістю бластів на 8-й день преднізолонової префази (PRED) менше 1,0 Г/л та кістково-мозковою ремісією на 33-й день лікування; до ГСР увійшли хворі віком молодше 1 року або старше 6 років з ініціальним лейкоцитозом 20,0 Г/л і більше, бластемією на 8-й день терапії менше 1,0 Г/л та кістково-мозковою ремісією на 33-й день. До ГВР віднесені діти з бластемією на 8-й день терапії більше 1,0 Г/л і/або відсутністю кістково-мозкової ремісії на 33-й день I протоколу.

Згодом ДГЛЛУ стала частиною міжнародного дослідження ALLIC-BFM 2002, у якому взяли участь загалом 15 країн світу (130 центрів) [77]. Додатково у стратифікації до певних груп ризику враховувався відсоток бластів кісткового мозку (КМ) на 15-й день. Це терапевтичне дослідження передбачало проведення рандомізації пацієнтів з метою порівняльної оцінки ефективності та токсичності низки нових елементів лікувального протоколу. У протоколі М та блоках HR доза MTX була

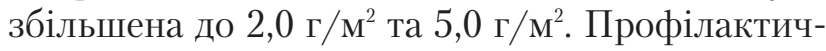
не опроміненя ЦНС (у дозі 12 Грей) отримували тільки пацієнти з Т-ГЛЛ і ГВР віком $\geq 1$ року. Терапевтична краніальна променева терапія була у пацієнтів з ініціальним ураженням ЦНС та призначалася в дозуванні з віком: 12 Гр для дітей віком від 1-го до 2-х років і 18 Гр для дітей віком $\geq 2$ років.

Остання версія протоколу лікування дітей з ГЛЛ міжнародної групи BFM - ALLIC-BFM 2009 грунтується на імуноцитологічному визначенні мінімальної залишкової - резидуальної - пухлини - (molecular residual disease (MRD) на 15-й день індукційної терапії із роз- поділом пацієнтів до тієї чи іншої групи ризику. Впровадження такого моніторингу дозволило індивідуалізувати терапію кожного окремого пацієнта із поліпшенням загального результату його лікування $[1,77]$.

Надалі продовжуються клінічні дослідження нових методів лікування групи пацієнтів iз резистентними формами та рецидивами ГЛЛ, які повинні поліпшити прогноз перебігу хвороби. Тому узагальнюючий аналіз застосування модифікованих міжнародних протоколів групи BFM у дітей, хворих на ГЛЛ, впродовж 25 років буде цікавим та корисним для покращення результатів їх лікування.

Mema дослідження: проведення порівняльного аналізу та узагальнення результатів лікування ГЛЛ у дітей за 25 років при застосуванні модифікованих програм цитостатичної терапії міжнародної групи BFM.

\section{Матеріал і методи дослідження}

У 370 дітей віком від 0 до 18 р., хворих на ГЛЛ, проаналізовано результати лікування за стандартами цитостатичної терапії міжнародної групи BFM за період з лютого 1993 р. до березня 2018 р.

Діагноз ГЛЛ встановлювався на підставі клінічної картини, лабораторних досліджень: загальний аналіз крові та сечі, цитологічні (підрахунок гемограми та мієлограми, цитозу ліквору, у препаратах, виконаних на цитоспіні, у паноптично забарвлених мазках за МейГрюнвальд-Гімза), біохімічний аналіз крові; проводилися цитохімічні реакції, імунофенотипові дослідження методом проточної цитометрії з використанням моноклональних антитіл (МКАТ). Сукупність поверхневих і цитоплазматичних маркерів у більшості випадків ГЛЛ була підставою для встановлення лінійної належності, виділення стадій зрілості прекурсорів В- чи Т-лімфоцитів. Для оцінки лінійної належності бластних клітин користувалися критеріями діагностики GALGB та EGIL [8, 13-16].

На основі концепції відповідності фенотипу злоякісних клітин виділено низку імунологічних варіантів, що визначають клітинну природу лейкемії і рівень блоку диференціації у неопластичній популяції. Експресією антигена вважали позитивною, коли частка бластів, на поверхні яких знаходився антиген, становила не менше 20,0\% для лімфоїдних та лінійно-незалежних і 30,0\% для мієлоїдних маркерів $[57,83]$. Тому надалі в таблицях і у тексті весь 
аналіз матеріалу, включаючи статистичний, проводився з урахуванням цих меж. Застосовувалися наступні методи візуалізації: рентгенографія органів грудної клітки, ультразвукове дослідження (УЗД), за потреби - комп'ютерна томографія (КТ) та/або магнітно-резонансна томографія (МРТ) голови, органів грудної клітки, черева; пункційна та трепанобіопсія КМ. Проводилося незалежне дослідження препаратів та визначення MRD у Референтній лабораторії НДСКЛ «ОХМАТДИТ» (м. Київ).

Алогенна трансплантація гемопоетичних стовбурових клітин / кісткового мозку (ало-ТГСК /ало-ТКМ) від неродинного донора виконувалася у всіх випадках у закордонних клініках.

Для аналізу застосовано програму статистики Statistica for Windows 8.0 (Statsoft, USA). Функція безподійного виживання - event-free survival (EFS), безрецидивне виживання (disease-free survival (DFS) та загального кумулятивного виживання - overall survival (OS) з першого діагнозу до смерті з будь-якої причини розрахована методом Каплан-Маєра. Порівняння виживання між групами проводилося за допомою Cox's-F-test.

Дослідження виконані відповідно до принципів Гельсінської Декларації. Протокол дослідження ухвалений Локальним етичним комітетом (ЛЕК) установи. На проведення досліджень було отримано поінформовану згоду батьків дітей. (або їх опікунів).

\section{Результати досліджень}

За період з лютого 1993 р. до березня 2018 р. у відділенні гематології та інтенсивної хіміотерапії КЗ ЛОР ЗУСДМЦ проліковано 370 хворих на ГЛЛ віком від 0 до 18 р. (в аналіз не включені пацієнти, які вибули з-під спостереження). Медіана спостереження (МC) за загальною вибіркою хворих становить 118 міс. Хлопчики становлять 54,49\% (209 осіб), дівчатка - 45,51\% (161 дітей), співвідношення 1,3:1. Переважали пацієнти віком від 1 до 6 років - 209 (56,49\%). Наступною за чисельністю була група осіб, старших за 6 та молодших за 12 років - 99 (26,76\%). Пацієнтів старшого віку (після 12 років) нараховано 50 (13,51\%). Дітей до 1 року було 12 (3,24\%).

У 319 (86,22\%) хворих виконано імунофенотипування бластних клітин. За імунофенотиповим варіантом у абсолютної більшості діагностовано В-клітинні ГЛЛ - у 82,13\%
(262 хворих), Т-ГЛЛ - у 46 (14,42\%) осіб, лейкемії з ознаками гібридного або змішаного фенотипу (mixed-phenotype acute leukemia), коли спостерігали одночасно коекспресію на лейкемічних бластах В-, Т-клітинних та мієлоїдних антигенів [28,34,37,42,43,45,50,59,60], у 11 (3,45\%) пацієнтів, причому В + Т+Му-ГЛЛ у 7/11 та Т+B+Му-ГЛЛ у 4/11 випадків. Серед В-лінійних переважали діти із фенотипом common (ВІІ)-ГЛЛ - 88,55\% (232 хворих); про-В (ВI) ГЛЛ становили 6,87\% (18 осіб); пре-В (BIII)-ГЛЛ діагностували лише у 4,58\% (12 дітей). Виявлено експресію тільки В-клітинних антигенів у 194 (74,05\%) дітей. У 59 пацієнтів констатували аберантну експресію одного або двох мієлоїдних антигенів на В-лімфобластах. Лише у $3,44 \%$ пацієнтів (9 випадків) на В-бластах верифіковано асинхронні Т-клітинні маркери. Т-лінійну ГЛЛ без експресіі антигенів інших ліній встановлено у 40 (86,96 \%) дітей, у 13,04\% (6 осіб) Т-бласти мали мієлоїдні маркери (табл. 1).

Із лютого 1993 р. до жовтня 2002 р. 143 (38,65\%) пацієнти отримали лікування на основі програм ГЛЛ-ДГЛУ 93/95 (базові протоколи ALL-BFM'90/95) (група 1); з листопада 2002 р. до червня 2012 р. 131 (35,41\%) хворий - ALL IC-BFM 2002 (група 2); із червня 2012 р. 88 (23,78\%) хворих отримали ALL IC-BFM 2009 (група 3). Діти віком до 1 року (8 осіб) із серпня 2008 р. лікувалися за програмами INTERFANT 99/06 (група 4).

Добру відповідь на ініціальну терапію преднізолоном (prednisolon good response (PGR), коли абсолютна кількість бластів на восьмий день протоколу I становила менше 1,0 Г/л, було відзначено у більшості хворих - 306 (82,70\%) осіб. У 64 (17,30\%) дітей число бластів у периферичній крові становило більше 1,0 Г/л (prednisolon poor response (PPR), серед них було 27 (42,19\%) дівчаток та 37 (57,81\%) хлопчиків (табл. 2).

Зазначимо, що первинна відповідь на ініціальну терапію PRED не залежить від статі

\begin{tabular}{|l|c|}
\multicolumn{1}{c}{ Лінійний розподіл глл } & Таблиия 1 \\
\hline \multicolumn{1}{c|}{ Лінійний розподіл } & Кількість випадків \\
\hline Тільки В-антигени & 194 \\
В+Т-антигени & 9 \\
В+Му-антигени & 59 \\
В+Т+Му-антигени & 7 \\
\hline Тільки Т-антигени & 40 \\
Т+Му-антигени & 6 \\
Т+В+Му-антигени & 4 \\
\hline Усього & 319 \\
\hline
\end{tabular}


Таблиия 2

Аналіз первинної відповіді на терапію з розподілом хворих за терапевтичним ризиком

\begin{tabular}{|l|c|c|c|c|c|c|c|c|}
\hline \multicolumn{1}{|c|}{ Програма лікування } & $\mathbf{8 - и ̆ ~ д е н ь ~}$ & $\mathbf{1 5 - и ̆ ~ д е н ь ~}$ & $\begin{array}{c}\text { Рання } \\
\text { смерть }\end{array}$ & $\begin{array}{c}\text { 33-й } \\
\text { день* }\end{array}$ & 33-й день & ГНР & ГСР & ГВР \\
\hline & PPR & NR & & NR & ремісія & & & \\
\hline ГЛЛ-ДГЛЛУ 93/95, $\mathrm{n}=143$ & $18(12,59 \%)$ & - & $7(4,89 \%)$ & $1(0,7 \%)$ & $135(94,4 \%)$ & $25(17,48 \%)$ & $100(69,93 \%)$ & $18(12,59 \%)$ \\
\hline ALL IC-BFM 2002, $\mathrm{n}=131$ & $23(17,56 \%)$ & $25(19,08 \%)$ & $2(1,53 \%)$ & $4(3,05 \%)$ & $125(95,42 \%)$ & $16(12,21 \%)$ & $88(63,21 \%)$ & $27(20,61 \%)$ \\
\hline ALL IC-BFM 2009, $\mathrm{n}=88$ & $18(20,45 \%)$ & $27(30,68 \%)$ & $1(1,14 \%)$ & $2(2,27 \%)$ & $85(96,59 \%)$ & $3(3,41 \%)$ & $56(63,64 \%)$ & $29(32,95 \%)$ \\
\hline Interfant 99/06, $\mathrm{n}=8$ & $5(62,50 \%)$ & - & $1(12,5 \%)$ & 2 & $5(62,5 \%)$ & - & $3(37,5 \%)$ & $5(62,50 \%)$ \\
\hline Усього, $\mathrm{n}=370$ & $64(17,30 \%)$ & - & $11(2,97 \%)$ & $9(2,43 \%)$ & $350(94,59 \%)$ & $44(11,89 \%)$ & $247(66,76 \%)$ & $79(21,35 \%)$ \\
\hline
\end{tabular}

Примітка. *Не враховано 11 дітей, померлих до 33-го дня індукційної терапії.

хворої дитини ( $>0,05)$. Встановлено, що показник EFS був значно нижчим у дітей із поганою відповіддю на преднізолонову префазу (EFS 56,8\%) порівняно 3 особами, абсолютна кількість бластів у яких на 8-й день лікування становила <1,0 Г/л (EFS 76,9\%) $(\mathrm{p}=0,00001)$.

Аналіз частоти досягнення кістково-мозкової ремісії на 33-й день індукційного лікування свідчить, що цей показник є досить високим (94,59\%). Не відповідали на індукційну терапію $10(2,7 \%)$ пацієнтів, троє 3 них належали до групи 4. Рання смерть зареєстрована у 11 (2,97\%) пацієнтів від сепсису під час індукційної терапії.

Кумулятивне виживання у всій вибірці становить 78,0\% (рис.2). Загалом померло 73 (18,7\%) дітей. У 32 (43,8\%) осіб смерть пов'язана з терапією I лінії ГЛЛ, 3 них 11 (34,37\%) хворих померли до досягнення ремісії ГЛЛ під час індукційної терапії, 19 (59,37\%) дітей - від септичних ускладнень у ремісії I на різних етапах інтенсивної хіміотерапії, 1 хворий з HR - від посттрансплантаційних ускладнень, 1 хворий - на 160 міс. після досягнення ремісії від фульмінантного перебігу вірусного гепатиту В. У 39 (53,42\%) хворих смерть настала у II гострому періоді від прогресування лейкемії та/або інфекційних ускладнень.

Більшість пацієнтів - 248 (67,02\%) - належали до ГСР. Другою за чисельністю була ГВР 77 (20,81\%) осіб. У ГНР налічувалося 45 (12,17\%) хворих. У загальній вибірці показник EFS був достовірно найнижчим у дітей з ГВР порівняно із ГНР та ГСР (56,3\% vs 77,9\% vs $77,9 \%, p=0,00000$ ).

У терапевтичному протоколі ГЛЛ-ДГЛЛУ 93/95 відзначено 18 (12,59\%) пацієнтів PPR, яких віднесено до ГВР. Один з них $(0,7 \%)$, NR, не досягнувши ремісії на 33-й та 52-й день індукційної терапії, продовжив лікування за кордоном, де помер від післятрансплантацій- них ускладнень. У групі 1 найчисельнішою була ГСР - 100 (69,93\%) дітей, а у ГНР налічувалося 25 (17,48\%) осіб.

Серед пацієнтів, яким застосовувалася терапія ALL IC-BFM 2002, до ГВР стратифіковано 27 (20,61\%) осіб. 3-поміж них PPR 23 (85,19\%) дітей, 3 доброю відповіддю на преднізолон, PGR, були 4 (14,81\%) особи, які не досягнули кістково-мозкової ремісії на 15-й день. Число бластів $\geq 5,0 \%$ було у 25 (19,08\%) хворих, незалежно від відповіді на терапію преднізолоном. На 33-й день статус NR відзначено у 4-х (3,05\%) осіб. MRD на 33-й день - у 10 (7,63\%) хворих, зних шестеро досягнули молекулярної ремісії на 52-й день. 4-м пацієнтам з ГВР у І ремісії ГЛЛ проведено ало-ТСГК від неродинного донора, три з яких - успішні. Діти перебувають у довготривалій ремісії. Одна пацієнтка загинула від рецидиву ГЛЛ після ТКМ. 16 (12,21\%) хворих стратифіковані до ГНР, а найбільше осіб віднесені до ГСР 88 (63,18\%) дітей у групі 2.

При проведенні терапії ALL IC-BFM 2009 3 (3,41\%) дітей належали до ГНР та перебувають у клініко-гематологічній ремісії. У ГСР налічувалося 56 (63,64\%) хворих. За терапевтичною відповіддю у ГВР було 29 (32,95\%) осіб.

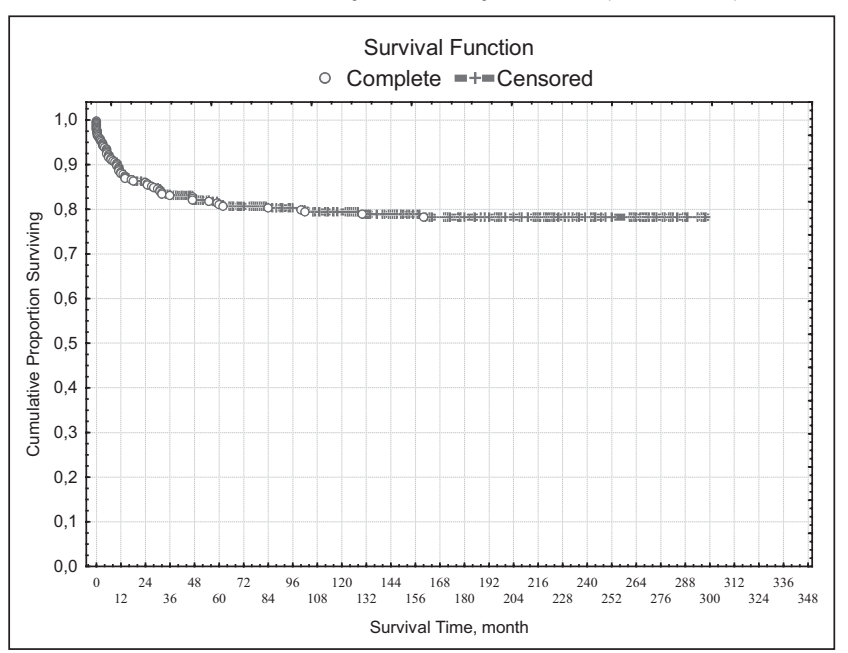

Рис.2. Кумулятивне виживання, OS 78,0\%, у загальній вибірці хворих на ГЛЛ 


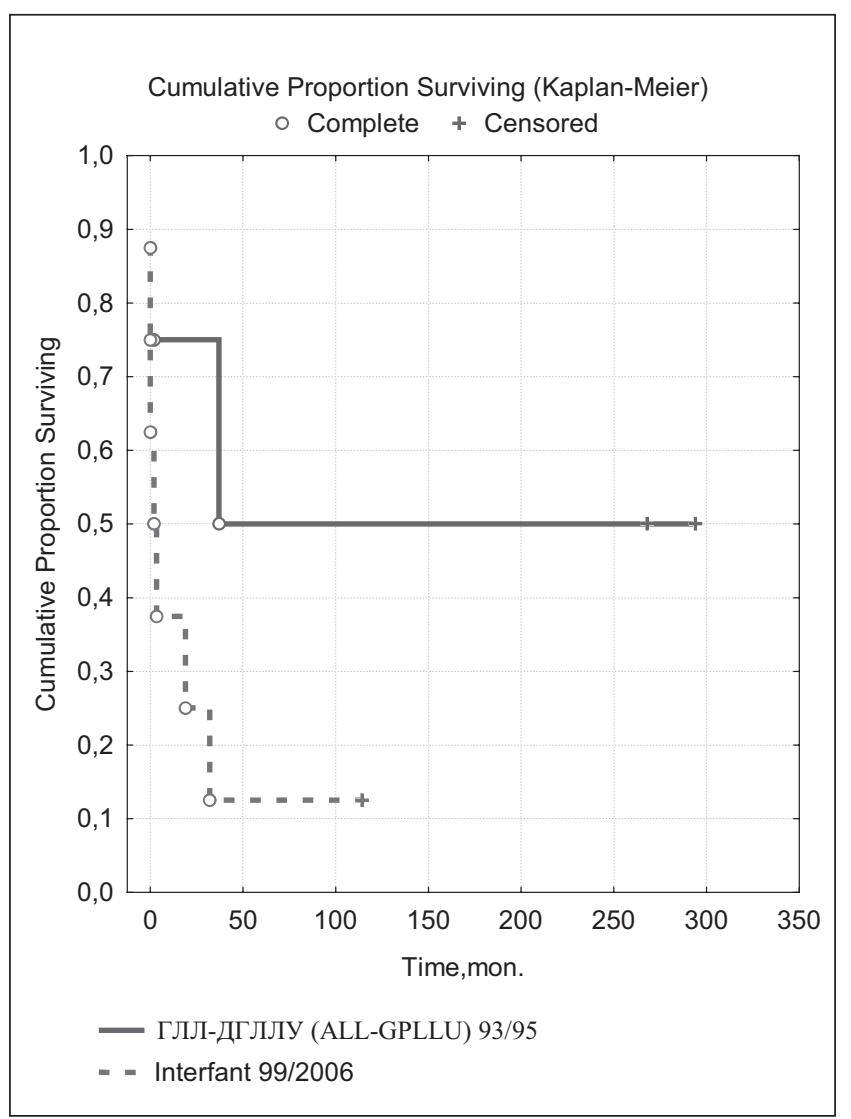

Pис. 3. EFS у дітей до 1 року залежно від застосованого протоколу, Cox's-F-test, $\mathrm{p}=0,11$

Причому У ГВP PPR було 18 та PGR 11 хворих. На 15-й день MDR>10,0\% констатовано у 27 3 них. У 2 (2,27\%) дітей на 33-й день не досягнуто статусу кістково-мозкової ремісії.

У дітей до 1 року, які лікувалися за протоколами INTERFANT 99/06, лише 3 із 8 осіб були PGR, причому у двох з них через 19 та 31 міс. констатовано рецидив ГЛЛ, згодом у II ремісії виконана ало-ТКМ. У одного пацієнта на 129-й день після ало-ТСГК діагностували ЦНС-рецидив хвороби. Один пацієнт перебуває у I ремісії 117 міс. Один 4-місячний хлопчик помер під час індукційної терапії від токсикосептичних ускладнень. У половини хворих до 1-го року з групи 4 exitus letalis - від прогресування ГЛЛ.

Четверо (2,8\%) дітей до 1-го року лікувалися згідно 3 програмою ГЛЛ-ДГЛЛУ 93/95. 3 них один 3-місячний хлопчик з ГВР помер на 3-му місяці індукційного лікування від сепсису. У одного пацієнта з ГСР в 11-місячному віці діагностовано ГЛЛ. Через 37 міс. після досягнення ремісії розвинувся пізній комбінований, кістково-мозковий та ЦНС, рецидив ГЛЛ. Він перебуває у тривалій II клініко-гематологічній ремісії 226 міс. Двоє дівчаток (ГЛЛ діагно- стовано у 9 міс. та 11 міс. з ГВР, PPR) перебувають у ремісії 296 та 271 міс. відповідно. Ми виявили суттєву різницю у EFS - 50,0\% проти 12,5\% у дітей до 1 року, які лікувалися згідно 3 протоколами ГЛЛ-ДГЛЛУ 93/95 та Interfant 99/06 відповідно. На нашу думку, через малу вибірку пацієнтів не знайдено статистичної різниці між цими групами $(\mathrm{p}=0,11)$ (рис.3).

У результаті проведеного лікування станом на 1 березня 2018 р. у клініко-гематологічній ремісії перебували 317 (85,68\%) дітей. 3 них 215 (67,82\%) хворих спостерігалися понад 5 років, і у них не було зареєстровано подій (рецидиву, резистентності до терапії, смерті, вторинні пухлини). За час дослідження події виникли у 90 (24,32\%) хворих. Абсолютна більшість подій $(92,22 \%$ - 83 особи) ставалися

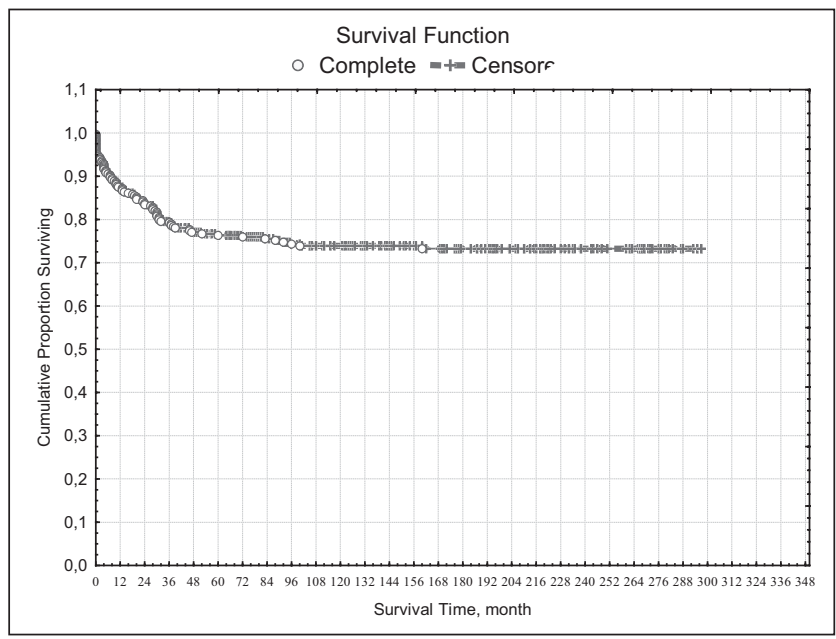

Pис.4. EFS 73,2\% у загальній вибірці хворих на ГЛЛ

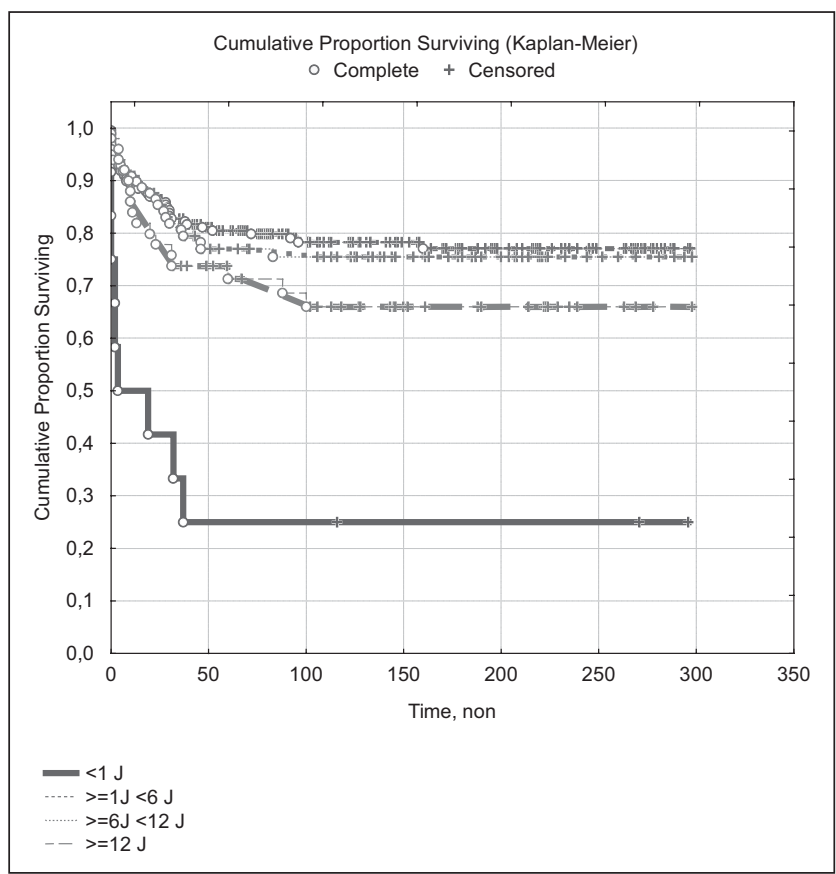

Рис.5. EFS залежно від віку, Cox's-F-test, $\mathrm{p}=0,00004$ 


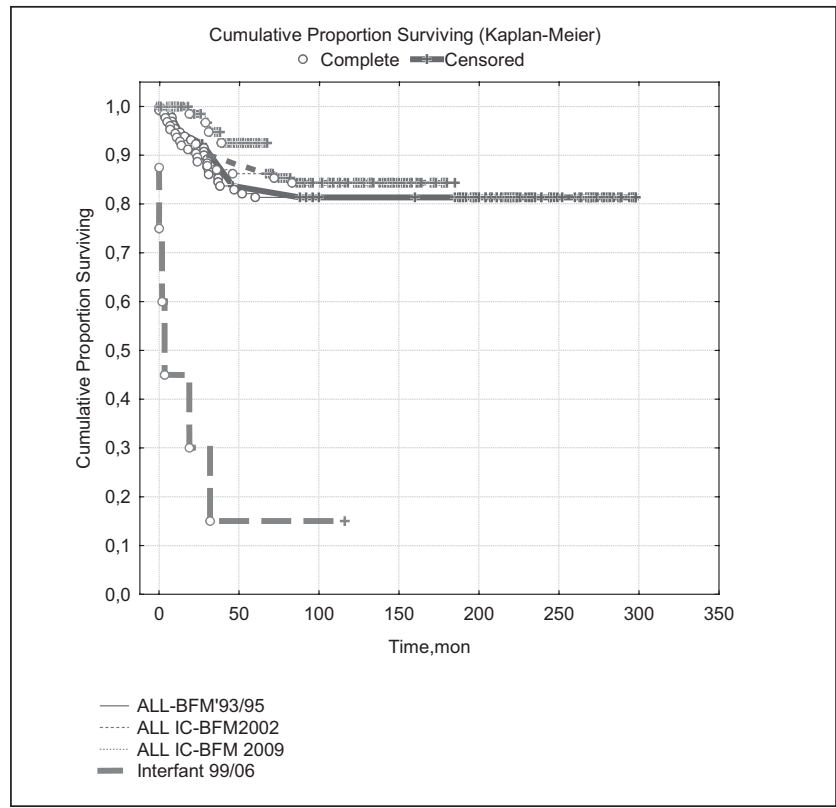

Pис.6. EFS у хворих на ГЛЛ при проведенні різних протоколів групи BFM, Cox's-F-test, $p=0,00000$

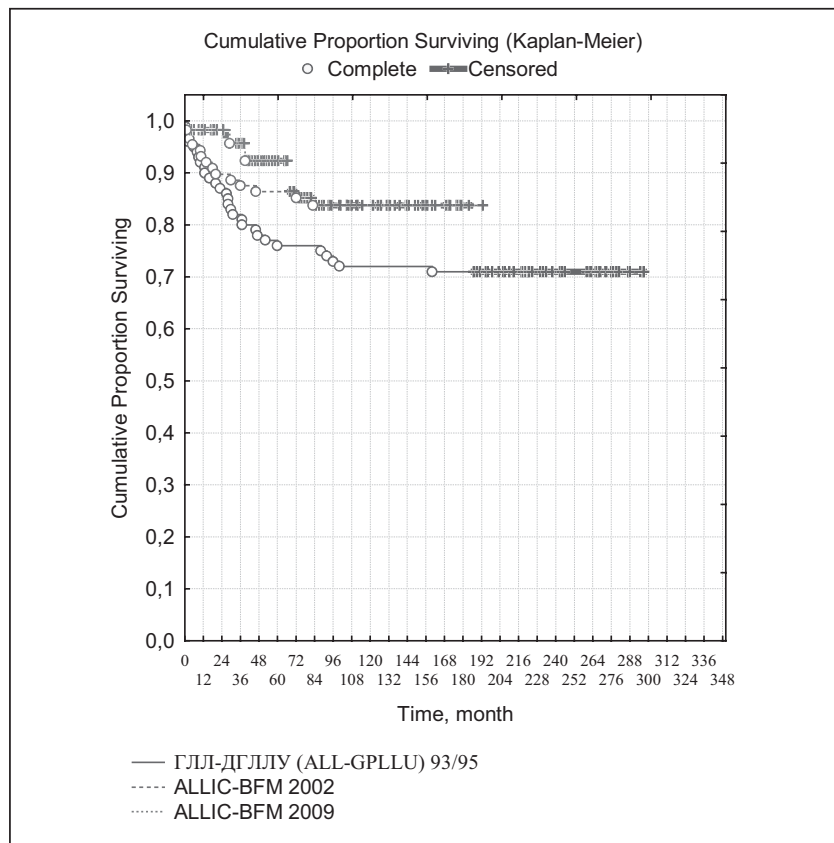

Pис.7. EFS у хворих на ГЛЛ у групі середнього ризику при проведенні різних протоколів групи BFM, Cox's-F-test, $\mathrm{p}=0,04232$

не пізніше 60 місяця з початку спостереження.Частка EFS за весь період спостереження становить $73,2 \%$ (рис.4).

Статистично встановлено, що показник EFS був вищим у дівчат порівняно з хлопчиками (80,0\% проти 67,8\%, p=0,021). Вірогідно гірші терапевтичні результати спостерігали у дітей віком до 1 року $(25,0 \%)(\mathrm{p}=0,00004)$ (рис. 5).

Значно коротшою була тривалість EFS у дітей, які отримали лікування Interfant 99/06 (12,5\%), ніж при застосуванні інших протоко-

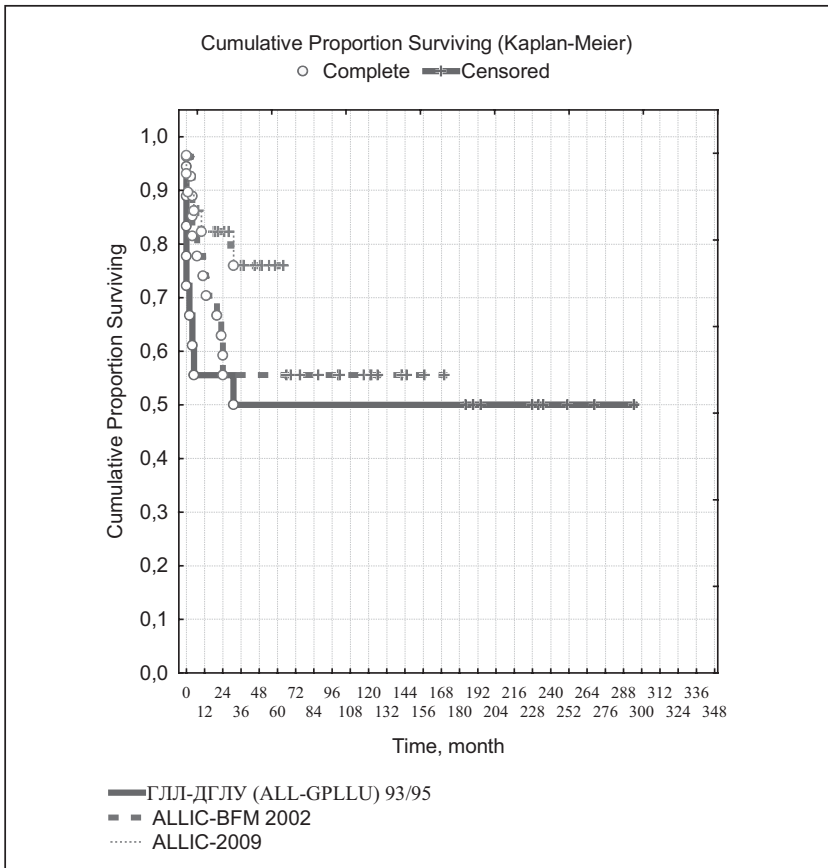

Рис.8. EFS хворих на ГЛЛ у групі високого ризику при проведенні різних протоколів групи BFM, Cox's-F-test, $\mathrm{p}=0,09653$

лів ГЛЛ ( $\mathrm{p}=0,00000)$ (рис.6). Результати лікування були значно кращими у дітей, які отримали терапію за програмою ALL IC-BFM 2009, порівняно $з$ дітьми групи 1 (85,2\% проти 68,3\%, $\mathrm{p}=0,0253)$. Встановлено, що не було відмінностей у EFS між групами 1 та $2(\mathrm{p}=0,19)$, також показник EFS вірогідно не відрізнявся між групами 2 та $3(\mathrm{p}=0,14)$.

У загальній вибірці доведено, що діти з ГВР мали значно менший відсоток EFS (56,3\%) порівняно з хворими, які належали до ГНР (77,9\%) та ГСР (74,9\%), p=0,00000.

Порівняльний аналіз у ГСР продемонстрував, що терапія була ефективнішою при проведенні програми ALL IC-BFM 2009, ніж у дітей 3 групи ГЛЛ-ДГЛЛУ 93/95 (EFS 90,6\% vs $71,0 \%, \mathrm{p}=0,03125)$. Таку ж тенденцію виявлено між групами 1 та 2 для дітей, які належали до ГСР (71,0\% vs 83,7\%, p=0,066) (рис.7). Не знайдено достовірної різниці у EFS між пацієнтами з ГСР, які отримали програмне лікування ALL IC-BFM 2002 та ALL IC-BFM $2009(\mathrm{p}=0,24312)$.

Схожі результати виявлено у пацієнтів з ГВР, які належали до вищезгаданих терапевтичних курсів (група $1-50,0 \%$ vs група $3-$ $73,9 \%, p=0,04560$ ) (рис. 8). Показник EFS у ГНР не мав зв'язку із застосованим терапевтичним протоколом (група $1-72,0 \%$ vs група $2-$ $81,3 \%$ vs група $3-100,0 \%)$. 


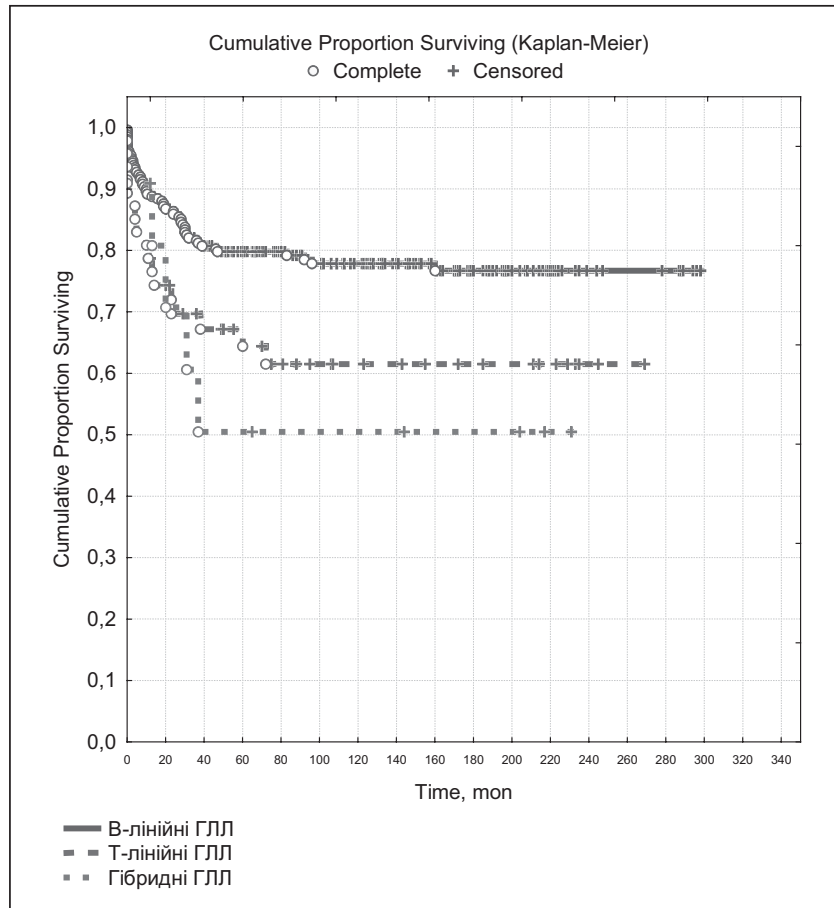

Pис. 9. EFS залежно від імунофенотипового варіанту ГЛЛ, Cox's-F-test, $p=0,00102$

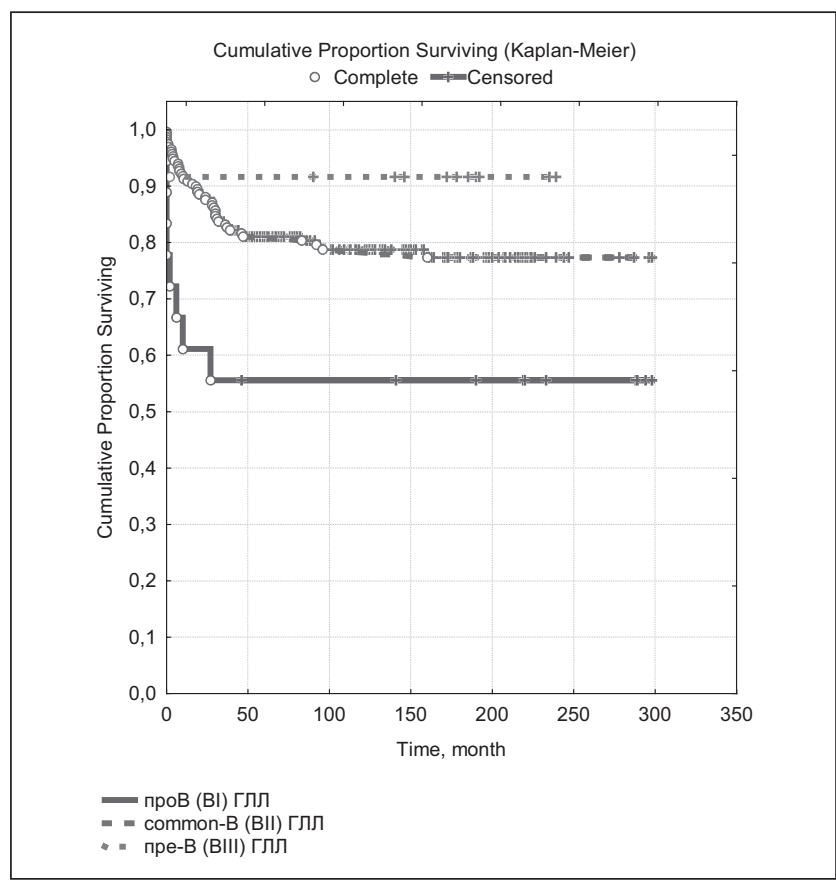

Pис.10. EFS у дітей 3 з різними варіантами В-лінійної ГЛЛ, Cox's-F-test, $p=0,00449$

Встановлено, що EFS у дітей із гібридним імунофенотипом був найнижчим $-50,6 \%$, найкращим у всій вибірці В-лінійних ГЛЛ $-76,6 \%$, а у осіб із Т-ГЛЛ -60,7\% (p=0,00102) (рис. 9).

Результати лікування були вірогідно кращими у пацієнтів з пре-В ГЛЛ та common-В-ГЛЛ, ніж із про-В-лейкеміями ( $\mathrm{p}=0,00449)$ (рис. 10). Коекспресія мієлоїдних чи Т-лінійних маркерів у хворих на лейкемії з імунофенотипом

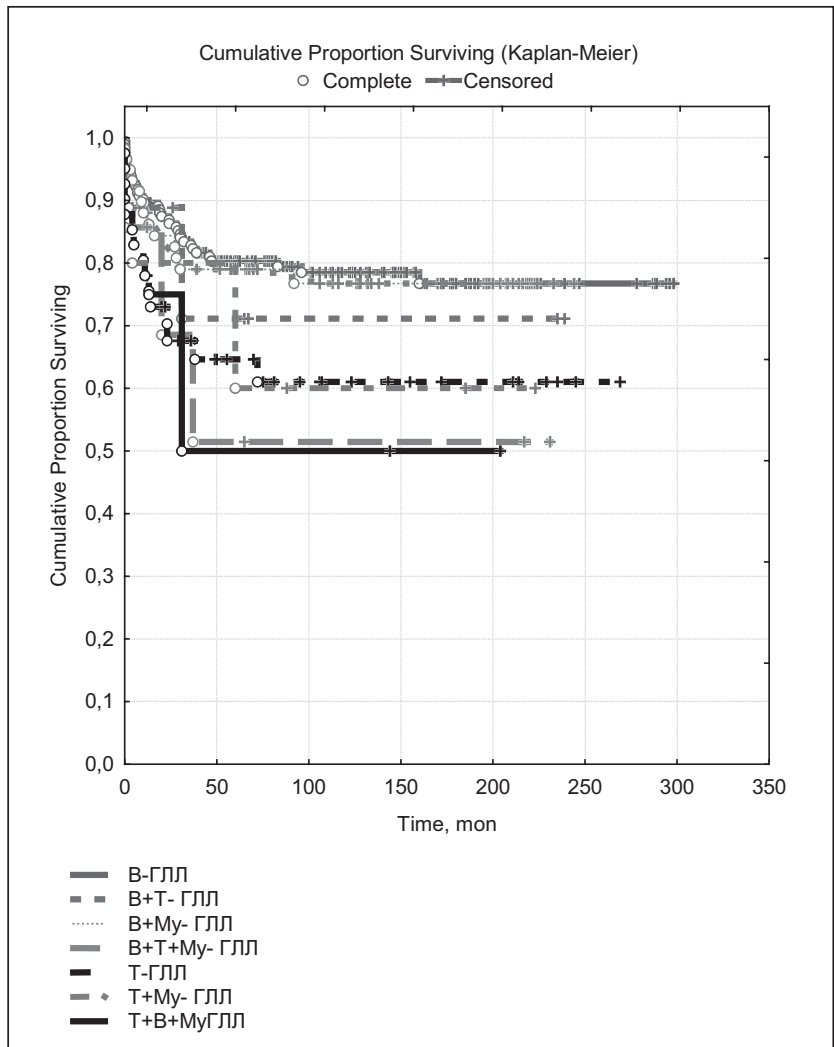

Pис.11. EFS залежно від імунофенотипового підваріанту ГЛЛ, Cox's-F-test, $p=0,18533$

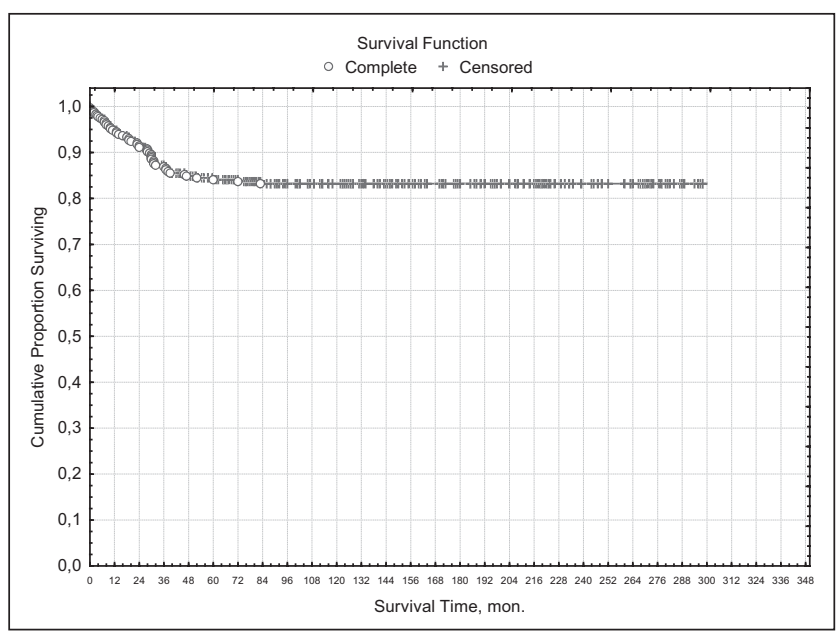

Pис.12. DFS 83,2\% у загальній вибірці хворих на ГЛЛ

B-лінії не мала впливу на EFS («чисті» В-лінійні ГЛЛ - 76,6\% vs В+Му-ГЛЛ - 76,8\% vs B+Т-ГЛЛ - 73,3\%, p=0,90810). Не знайдено значущого зв'язку між показником EFS у дітей 3 Т-лінійною ГЛЛ та Т+Му-ГЛЛ (58,9\% vs $64,8 \%, \mathrm{p}=0,60456$ ) (рис. 11 ).

Достовірно встановлено, що хворим на про-В ГЛЛ притаманне високе число смертей (OS про-В-ГЛЛ - 55,6\% vs common-В-ГЛЛ 80,4\% vs пре-В-ГЛЛ - 91,7\%) порівняно 3 дітьми, яким діагностовано інші імунофенотипові підваріанти ГЛЛ ( $\mathrm{p}=0,00068)$. Доведено, що 
Аналіз рецидивів гострої лімфобластної лейкемії

Таблиия 3

\begin{tabular}{|l|c|c|c|c|c|}
\hline \multicolumn{1}{|c|}{ Рецидив } & $\begin{array}{c}\text { Кістково- } \\
\text { мозковий }\end{array}$ & Нейрорецидив & Тестикулярний & $\begin{array}{c}\text { Комбінований кістково-мозковий } \\
\text { + нейрорецидив }\end{array}$ & Усього \\
\hline Дуже ранній & 12 & - & - & 8 & $20(37,74 \%)$ \\
\hline Ранній & 7 & 3 & - & - & $10(18,86 \%)$ \\
\hline Пізній & 16 & 1 & 3 & 3 & $23(43,40 \%)$ \\
\hline Усього & $35(66,04 \%)$ & $4(7,55 \%)$ & $3(5,66 \%)$ & $11(20,75 \%)$ & $53(100,00 \%)$ \\
\hline
\end{tabular}

наявність змішаного фенотипу ГЛЛ супроводжується більшою частотою летальних наслідків (В-лінійні ГЛЛ - 79,6\% vs Т-ГЛЛ - 66,3\% vs ГЛЛ із одночасною коекспресію на лейкемічних бластах В-, Т-клітинних та мієлоїдних антигенів $-61,9 \%, \mathrm{p}=0,00916)$. Щодо розвитку рецидиву між окремими варіантами В-лінійної ГЛЛ не виявлено достовірної різниці ( $\mathrm{p}=0,21009)$. Не знайдено зв'язку із настанням рецидиву та наявністю на лімфобластах інших додаткових маркерів ( $\mathrm{p}=0,38370)$.

Незважаючи на те, що ГЛЛ добре реагує на хіміотерапію, рецидив залишається основною проблемою. У 53 (16,21\% з 327 хворих з вилученням $11 \mathrm{NR}$ та 32 померлих) виникли рецидиви хвороби. 3 них у $6(75,0 \%)$ пацієнтів зареєстровано рецидиви хвороби у групі 4 (із 8 дітей), у 4 (4,55\%) випадках - 388 осіб,

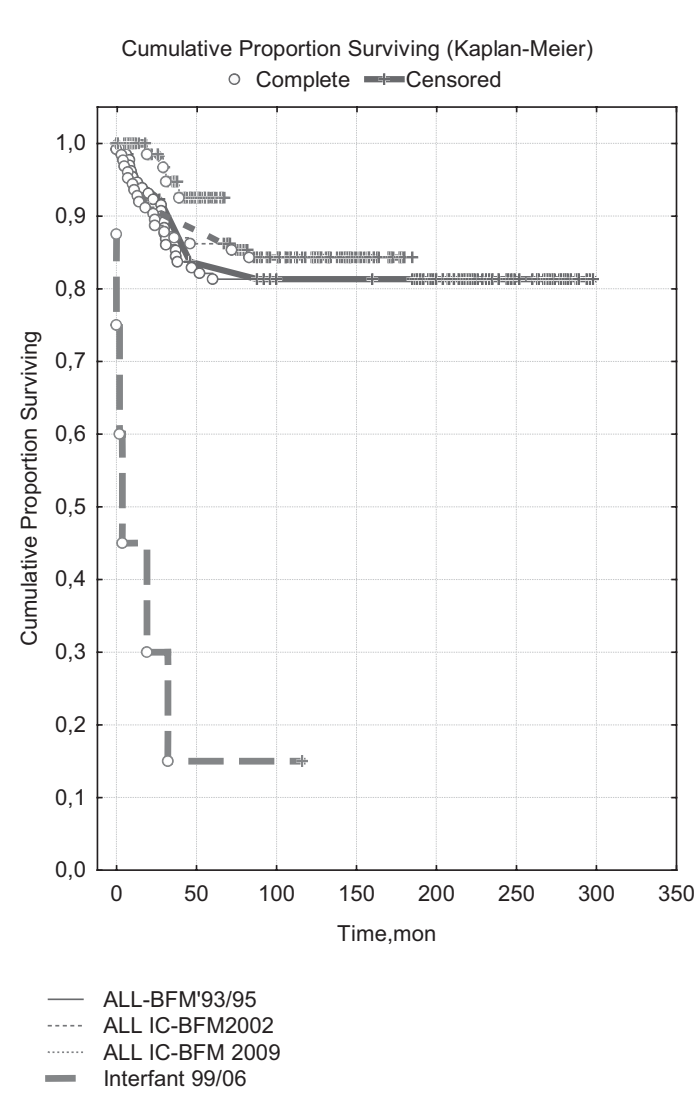

Рис.13. DFS при проведенні різних стандартних протоколів групи BFM, Cox's-F-test, $\mathrm{p}=0,00000$ які лікувалися за програмою ALL IC-BFM 2009, у 19 (14,50\%) пацієнтів 3-поміж 131 пацієнта 3 терапевтичної програми ALL IC-BFM 2002 та 24 (16,78\%) із 143 дітей групи 1. Безрецидивне виживання у загальній вибірці становить $83,2 \%$ (рис. 12 ).

Рецидив ГЛЛ діагностовано у 36 (17,22\%) хлопчиків та у 17 (10,56\%) дівчаток. Виявлено тенденцію до зниження показника DFS у хлопчиків порівняно з дівчатками (80,0\% vs $88,1 \%$, $\mathrm{p}=0,07018)$. За терміном реєстрації рецидиви були дуже ранніми (виникали до 18 міс. з часу початку первинної терапії ГЛЛ) у 20 (37,74\%) осіб та ранніми (у терміні 18-30 міс. від початку первинної терапії лейкемії) у 10 (18,86\%) випадках. Пізні рецидиви ГЛЛ (після 30 міс. від дебюту терапії І гострого періоду) зафіксовано у 23 (43,40\%) дітей. Дані щодо локалізації рецидивів відображено у табл. 3.

Доведено, що у загальній вибірці DFS було найнижчим у ГВР порівняно з ГНР та ГСР ( $85,2 \%$ vs $85,8 \%$ vs $74,8 \%, p=0,00726)$. Встановлено, що показник DFS достовірно найгірший у пацієнтів, які лікувалися за терапевтичним протоколом Interfant 99/06 (15,0\%), та найкращий у пацієнтів, які лікувалися згідно з програмою ALL IC-BFM 2009 (92,0\%), у групах 2 та $3-82,0 \%$ та $84,5 \%$ відповідно $(\mathrm{p}=0,00000)$ (рис.13).

Рідкісним віддаленим наслідком лікування ГЛЛ у дітей були вторинні злоякісні захворювання, які зареєстровано у 5 (1,35\%) дітей (рис. 14). Медіана віку на час діагностики ГЛЛ чотири роки. Медіана виявлення вторинних пухлин з часу початку первинної цитостатичної терапії -7 років 4 міс. (коливання 20-96 міс.). У 3/5 пацієнтів діагностовано вторинні пухлини головного мозку (ВПГМ). Середній вік на момент постановки первинного діагнозу ГЛЛ у цих осіб становив 7,4 року, вік на момент виникнення ВПГМ - 21 р. 7 міс., 11 р., 9 р. 4 міс. відповідно. Саме ці три пацієнти отримували лікування за модифікованою програмою поліхіміотерапії ГЛЛ-ДГЛЛУ 95 (на основі програми ALL-BFM'95). За резуль- 


\begin{tabular}{|c|}
\hline $\begin{array}{c}\text { Вторинні пухлини, після терапії І-го } \\
\text { гострого періоду ГЛЛ } \\
\text { у } 5(1,3 \%) \text { дітей виникли вторинні пухлини: }\end{array}$ \\
\hline $\begin{array}{l}\text { BFM 90-95 } \\
\text { - Олігодендрогліома (померла) } \\
\text { - Астроцитома (оперована, хіміотерапія, } \\
\text { променева терапія, живе, народила доньку) } \\
\text { - Доброякісна менінгеома (оперований, живе) }\end{array}$ \\
\hline $\begin{array}{l}\text { ALLIC-BFM } 2002 \\
\text { - Вторинна ГМЛ (живе після ТКМ) АГРЕСИВНА } \\
\text { - Вторинний МДС/ГМЛ (помер) }\end{array}$ \\
\hline $\begin{array}{l}\text { Медіана віку діагнозу ГЛЛ - } 4 \text { роки, } \\
\text { Медіана виникнення вторинних пухлин від часу } \\
\text { захворювання }-7 \text { р. } 4 \text { міс. ( } 20-96 \text { міс) }\end{array}$ \\
\hline
\end{tabular}

Pис. 14. Аналіз вторинних пухлин у пацієнтів, які отримали терапію за стандартними протоколами, групи BFM у дитячому віці з приводу ГЛЛ

татами первинної відповіді на індукційне лікування (добра відповідь на преднізолонову префазу, досягнуто клініко-гематологічної ремісії на 33-й день) усі згадані діти віднесені до терапевтичної групи ГСР. Одна пацієнтка 3 олігодендрогліомою померла від прогресування вторинної неоплазії. Двоє осіб з фібринозною астроцитомою та менінгіомою живуть. У жодного хворого з інших груп $-2,3$ чи $4-$ не зареєстровано ВПГМ.

У двох хлопців, які отримували терапію за програмою ALL IC-BFM-2002 (відповідно належності до терапевтичних груп ГСР та ГВР) зареєстровано через 20 міс. з часу початку первинної цитостатичної терапії вторинний гемобластоз (treatment-related myelodysplastic syndrome (t-MDS)/ treatment-related acute myeloid leukemia (AML) - t-MDS/t-AML). У одного пацієнта з ГСР виник вторинний мієлодисплатичний синдром (МДС) із моносомією 7, який згодом трансформувався у вторинну ГМЛ, хворому проведено алогенну трансплантацію гемопоетичних клітин (алоТГПСК) пуповинної крові. Пацієнт помер від посттрансплантаційних ускладнень. У іншого хворого із ГВР зареєстровано вторинну ГМЛ з транслокацією t(9.11) (p22; q23). Йому виконано ало-ТСГК. Пацієнт перебуває у клініко-гематологічній ремісії ГЛЛ 78 міс. та t-AML - 50 міс.

Ало-ТГСК виконано загалом 15-м особам. 3 них у І ремісії ГЛЛ у ГВР 8 осіб, включно з двома пацієнтами із вторинною $\mathrm{t}-\mathrm{MDS} / \mathrm{t}-\mathrm{AML}$, та 7 особу II ремісії ГЛЛ.

\section{Обговорення}

Лейкемії, з яких понад 95,0\% є гострими, $€$ найпоширенішою діагностичною групою дитячих онкологічних захворювань в усьому світі [51,78]. Досягнуто відчутного прогресу у лікуванні ГЛЛ, відзначеного 5-річним загальним виживанням, що сягає $90,0 \%$, як і у країнах з високим рівнем доходів [65]. Запровадження міжнародних протоколів поліхіміотерапії ГЛЛ групи BFM у відділенні гематології та інтенсивної хіміотерапії ЗУСДМЦ зумовило суттеве покращання результатів лікування дітей, що й засвідчує наше дослідження. Вважаємо, що показник загального кумулятивного виживання $78,0 \%$, EFS $72,3 \%$ та безрецидивного виживання $83,2 \%$ впродовж 25 років спостереження у нашому Центрі $є$ великим успіхом в онкогематології Європи та України зокрема. Досягнуті показники виживання відповідають результатам провідних світових центрів [65].

Нами виконано імунофенотипування бластних клітин у 319 осіб. Панель МКАТ включала специфічні антитіла до різних кластерів диференціації (CD): лінійно-незалежні, В-лінійні, Т-лінійні, а також окремі мієлоїдні. Досить цікавим явищем $є$ коекспресія, тобто наявність на морфологічно фенотипово встановлених клітинах гострих лейкемій детермінант 3 іншої лінії, т. з. «нетипових фенотипів» - «atypical phenotypes» [62]. Зустрічаються випадки гострого лейкозу зі змішаним фенотипом (mixed phenotype acute leukemia (MPAL), відомого ще як гостра біфенотипова або гібридна лейкемія), що є діагностичною та терапевтичною дилемою. MPAL становлять 3,0-5,0\% усіх випадків гострого лейкозу [70], що засвідчило наше дослідження. Ми встановили змішано-лінійну лейкемію у 11 (3,45\%) пацієнтів, причому $\mathrm{B}+\mathrm{T}+\mathrm{My-ГЛЛ} \mathrm{-} \mathrm{у} \mathrm{7/11}$ та $\mathrm{T}+\mathrm{B}+\mathrm{My-ГЛЛ} \mathrm{-} \mathrm{у} \mathrm{4/11} \mathrm{випадків.} \mathrm{За} \mathrm{даними}$ низки авторів, у 5,0-10,0\% хворих спостерігаються такі форми лейкемії, при яких бластні клітини на поверхневій мембрані містять більше двох лімфоїдних та мієлоїдних маркерів, або лейкемія одночасно є трилінійного походження [28,42,50].

Гостра лейкемія змішаного фенотипу це рідкісний тип лейкемії, який експресує як мієлоїдні, так і лімфоїдні маркери. Існує обмежена інформація, особливо щодо дітей, про ці варіанти лейкемій [59]. Система оцінки за європейською групою з імунологічної класифікації лейкемій (EGIL) однозначно визначає iï як лейкемію, що має аберантні маркери різних ліній гемопоезу. Класифікація лейкемій (EGIL) визначає гостру лейкемію змішаного 
фенотипу та описує три іï форми: гостра лейкемія з двома різними лейкозними популяціями, кожна з яких належить до іншої лінії [87], гостра лейкемія з раннім переходом від одного походження до іншого $[12,36]$ і гостра лейкемія з виразними аберантними молекулами (ті, які фізіологічно виражені в різних лініях) [35,60]. На думку E.G. Weir (2001), змішано-лінійні (гібридні) лейкемії є не що інше, як хронічна мієлоїдна лейкемія (ХМЛ) у змішаній лімфобластно-мієлоїдній кризі з виключно поганим прогнозом [88]. Ряд авторів вважають, що аберрантні молекули часто проявляються в подальшому лейкемічними рецидивами $[43,48]$. Діагностування таких фенотипів бластів у часі ремісії є основою для виявлення бластних клітин поміж фізіологічних елементів кісткового мозку для визначення залишкової хвороби, MRD [1,17,41,48-50,59,65,66,71,77,79,84,90], моніторинг якої успішно проводився у педіатричних пацієнтів України із ГЛЛ у Референтній лабораторії НДСКЛ «ОХМАТДИТ» (м. Київ). M. Khan та співавт. відзначають, що змішано-лінійні ГЛЛ мають значно гірший прогноз [34]. Подібні результати зі статистично меншим виживанням 53,0\% для лейкемій зі змішаним фенотипом проти 76,0\% у дітей 3 фенотипово «чистим» варіантом ГЛЛ подають E. Mejstrikova та співавт. (2010) [49]. У нашому дослідженні діти з гібридними формами лейкемії мали достовірно коротше EFS (50,6\%), ніж особи з В-лінійною та Т-ГЛЛ (EFS 76,6\% та 60,7\% відповідно, $\mathrm{p}=0,018$ ).

Ми підтвердили результати низки дослідників, що серед ГЛЛ переважають діти з фенотипом common (BII)-ГЛЛ - 88,55\% [3-5,8,88]. У 59 пацієнтів констатували аберантну експресію одного або двох мієлоїдних антигенів на В-лімфобластах. Лише у 3,44\% пацієнтів (9 випадків) на В-бластах верифіковано асинхронні Т-клітинні маркери. Т-лінійну ГЛЛ без експресії антигенів інших ліній встановлено у 40 (86,96\%) дітей, та у 13,04\% (6 осіб) Т-бласти мали мієлоїдні маркери. Слід зазначити, що у літературі з цього питання є значні розбіжності. Деякі автори подають значно вищі показники частоти аберантних експресій маркерів інших ліній при В-лінійних ГЛЛ. У дослідженні С.Н. Риі та співавт. (1998) у 31,4\% хворих на ГЛЛ спостерігали один або більше мієлоїдних антигенів, серед В-лінійних ГЛЛ - у 31,9\% хворих та у 28,8\% випадках Т-клітинної лейкемії [66].
Клінічне значення коекспресії маркерів на лімфобластах у дітей широко досліджується і має контраверсійний характер. Різні студії демонструють Му+ГЛЛ дітей як осіб із поганими результатами лікування $[22,37,89]$. Протилежні дані описують інші дослідники [64,67,68,83]. M.K. Howard та співавт. (1994) вважають, що різниця у результатах терапії може бути пов'язана із різними критеріями визначення Му+-маркерів та застосуванням різних протоколів лікування [29]. Дослідження H. Firat та співавт. (2001) продемонстрували, що визначення CD13 та CD33 залежить від визначального МКАТ і має коливання імунореактивності при дитячих ГЛЛ [23]. Австрійська група дослідників встановила, що діти $3 \mathrm{My+ГЛЛ} \mathrm{мають} \mathrm{значно} \mathrm{менше} \mathrm{виживання}$ [22]. Вони спостерігали у хворих на ГЛЛ з кМу значно вищий ініціальний лейкоцитоз, ніж у дітей, на лімфобластах яких не виявлялась коекспресія Му-маркерів. На думку авторів, більше 40,0\% хворих на Му+ГЛЛ припадає на CD10- про-В ГЛЛ [22]. Вважається, що ці хворі на ГЛЛ мають найгірший прогноз 3-поміж всієї групи дітей із кМу. Подібні дані подають S. Wiersma та співавт. (1991) [89]. На противагу до них інші дослідники не знаходять статистичної різниці у виживанні між особами із додатньою коекспресією Му-маркерів та мієлонегативними випадками ГЛЛ, хоча EFS у Му+ хворих є дещо коротшим [45,64]. Кардинально протилежною $є$ думка російських вчених, що наявність мієлоасоційованих антигенів у дітей, хворих на В-лінійну ГЛЛ, є сприятливим прогностичним фактором [4]. Подібно до них Г.В. Коленкова і співавт. (1997) описали, що випадки ГЛЛ без експресії стовбурового антигена та мієлоїдних антигенів виявились схильними до виникнення дуже ранніх та ранніх рецидивів [3]. У дослідженнях малайзійської популяції групи Му+В ГЛЛ та Му-В ГЛЛ не відрізнялися за демографічними та клінічними характеристиками [57]. Нами теж не знайдено суттєвої різниці у виживанні пацієнтів мієлонегативних та позитивних В- та Т-лінійних ГЛЛ.

Більшість дослідників вважають, що фактором несприятливого прогнозу при дитячій В-лініний та Т-клітинній ГЛЛ є погана первинна відповідь на преднізолонову префазу [2,18,19,25,26,31,68,69]. У дослідженні ALL-BFM 83, яка вперше ввела прогностичний фактор відповідь на преднізолонову префазу, 13-річ- 
ний EFS у групі PGR та PPR становили відповідно 65,0\% проти 39,0\% [76]. Добру відповідь на ініціальну терапію преднізолоном нами відзначено у переважної кількості хворих 306 (82,70\%) осіб. Встановлено, що показник EFS був значно нижчим у дітей із поганою відповіддю на преднізолонову префазу (EFS 56,8\%) порівняно з особами, абсолютна кількість бластів у яких на 8-й день лікування становила $<1,0$ Г/л (EFS 76,9\%) $(\mathrm{p}=0,00001)$, що відповідає даним низки досліджень [2,18,19,25,26, 31,68,69]. Покращання терапевтичних результатів у дітей із поганою відповіддю на лікування студії BFM вдалося досягти завдяки інтенсифікації хіміотерапії. У порівняльному аналізі досліджень групи BFM демонструється суттєве покращання результатів лікування, пов'язане з інтенсифікацією терапії наростанням дози МТХ, що й підтверджує наше дослідження [74,76]. Аналіз частоти досягнення кістково-мозкової ремісії на 33-й день індукційного лікування показав, що цей показник є досить високим (94,59\%), що співзвучне із низкою наукових світових досліджень [5,68,75]. Діти до одного року демонструють найгірші рельтати лікування [19,20,61], що також підтвердило наше дослідження.

Рецидив ГЛЛ може виникнути в різні терміни від початку первинного лікування та вразити будь-який орган [21,32,56,80,81]. F. Bessho та співавт. (2013) описали розвиток рецидиву ГЛЛ аж через 34 роки з часу первинного діагнозу [9]. За даними літератури, найчастішим рецидивом є кістково-мозковий, який становить близько 50,0-97,0\% усіх рецидивів [51]. На ЦНС рецидив припадає в середньому у $8,0-15,0 \%$ випадків [32,38,51]. Існують повідомлення про сукупний ризик рецидиву ЦНС 0,9-4,0\% інших сучасних клінічних випробувань [63]. За п'ять років спостереження у студіях ALL-BFM 90 та ALL-BFM 95 зареєстровано ЦНС-рецидивів 2,9\% та 4,6\% відповідно, а рецидивів іншої локалізації - 15,9\% та 9,9\% відповідно. Близько 20,0\% усіх рецидивів припадає на ураження яєчок $[1,80,81]$. У нашому дослідженні рецидиви (разом із комбінованими) у ЦНС становили 15 (28,3\%), ізольований ЦНС $-7,55 \%$, у кістковий мозок - 46 (86,8\%) та тестикулярний $-3(5,66 \%)$ випадків усіх рецидивів.

Зі зниженням ризику рецидиву лейкемії цитостатичне лікування має ряд пізніх побічних впливів, які можуть розвинутись згодом.
Одним з пізніх ускладнень лікування є виникнення вторинних пухлинних захворювань $[24,27,58,70,73,86]$. Часовий діапазон виникнення вторинних неоплазій $(\mathrm{BH})$ після застосування цитостатичної терапії коливається від 0,9 до 20 років і більше [10,44]. Встановлено, що у осіб, які отримували протипухлинну терапію в дитинстві, у 7 [54] та 14 [44] разів вищий ризик щодо розвитку згодом другої злоякісної пухлини порівняно із загальнопопуляційною когортою. Серед ВН, що спостерігаються після лікування ГЛЛ, найчастіше реєструються пухлини ЦНС у хворих, які отримують краніальне опромінення [6,11]. Також у цій популяції хворих можливі вторинні лімфоми ГМЛ, МДС та рак щитоподібної залози [44]. Низка вчених стверджують, що вік пацієнта на час встановлення першого діагнозу і початку протипухлинного лікування має вагомий вплив на ризик розвитку пухлин головного мозку [44,56]. Існують наукові твердження, що у дітей із вперше діагностованою ГЛЛ у віці до 5 років із вторинних неопроцесів найчастіше згодом розвиваються ВПГМ, другою за частотою є МЛ. Усі інші види злоякісних процесів сукупно є третьою найчастішою групою [55]. Нами діагностовано вторинні злоякісні захворювання у 5 (1,35\%) дітей, які отримували терапію з приводу ГЛЛ. Медіана віку на час діагностування ГЛЛ у них становила 4 роки. Медіана виявлення вторинних пухлин з часу початку первинної цитостатичної терапії 7 років 4 міс. (коливання 20-96 міс.). У 3/5 пацієнтів діагностовано вторинні пухлини головного мозку, у 2/5 - гемобластози ГМЛ та МДС, який згодом транформувася у ГМЛ, що відповідає даним вищезгаданих публікацій.

Враховуючи вищезазначене, ми вважаємо, що коригування терапії згідно з результатами визначення MRD, дають змогу індувідуально підходити до кожного пацієнта, застосовуючи більш інтенсивні методи лікування за необхідності, a y групах з меншим показником MRD зменшуючи побічні токсичні ефекти для поліпшення виживання дітей з гострим лейкозом в Україні.

\section{Висновки}

Програми лікування ГЛЛ міжнародної групи BFM демонструють постійно зростаючу високу ефективність. Коекспресія мієлоїдних чи Т-лінійних маркерів у хворих на лейкемії із імунофенотипом В-лінії, мієлоїдних антигенів на T-бластах не має впливу на EFS. Доведе- 
но, що наявність гібридного та про-В-фенотипу ГЛЛ супроводжується гіршим EFS за рахунок більшої частоти летальних наслідків. Протокол ALL IC-BFM 2009 демонструє найкращу ефективність лікування не-В-гострої лімфобластної лейкемії у дітей. Коректна стратифікація хворих на групи ризику є вкрай важливою для забезпечення оптимального терапевтичного результату (максимум ефективності, мінімум токсичності). Лікування хворих високої групи ризику потре- бує подальшого пошуку шляхів як підвищення ефективності терапії, так і зниження їі токсичних ефектів. Результати лікування ГЛЛ у дітей першого року життя є незадовільними та потребують удосконалення терапевтичних підходів. Рідкісним віддаленим наслідком лікування ГЛЛ у дітей $є$ ВН, про що повинні пам'ятати лікарі першого контакту та вузькі спеціалісти.

Автори заявляють про відсутність конфлікту інтересів.

\section{ЛITЕPАТУРА}

1. Донська СБ. (2012). Результати лікування гострої лімфобластно лейкемії у дітей в Україні. Здоров'я України. http://healthua.com/pics/pdf/ZU_2012_Onko_5-6/30-31.pdf.

2. Дудкин СА, Чуниховский СП, Стренева ОВ и др. (2003). Промежуточный анализ мультицентрового исследования ALL-MB 91 и ALL-BFM 90: результаты терапии детей с инициальным гиперлейкоцитозом и Т-клеточным вариантом ОЛЛ. Актуальные проблемы гематологии и трансфузиологии: V съезд гематологов и трансфузиологов Республики Беларусь. Минск: Стринко: 204-205.

3. Коленкова ГВ. (2002). Маркеры острого лейкоза в диагностике и прогнозе заболевания у детей. Гематология и трансфузиология. 47(2): 28-35.

4. Ленская РВ, Коленкова ГВ, Тимаков АТ. (2000). Клиническое значение характера экспрессии CD-антигенов бластных клеток при остром лимфобластном лейкозе у детей. Экспериментальная онкология. 22(4): 191-194.

5. Armata J, Boguslawska-Jaworska D, Kolecki P, Kowalszyk J, Ochocka M, Radwanska U, Sonta-Jakimczyk D, Wachowiak J. (1998). Bialaczki u dzieci. Pod redakcja U. Radwalskiej. Wrocnaw (Poland): Volumed: 234.

6. Aung L, Khyne T, Yeoh AE, Quah TC, Tan AM. (2009). A report from the Singapore Childhood Cancer Survivor Study (SG-CCSS): a multi-institutional collaborative study on long-term survivors of childhood cancer, initial analysis reporting for the SG-CCSS. Ann Acad Med Singapore. 38(8): 684-689.

7. Barredo JC, Hastings C, Lu X, Devidas M, Chen Y, Armstrong D et al. (2017). Isolated late testicular relapse of B-cell acute lymphoblastic leukemia treated with intensive systemic chemotherapy and responsebased testicular radiation: A Children's Oncology Group study. Pediatr Blood Cancer. 65(5): e26928.

8. Bene MC, Castoldi G, Knapp W et al. (1995). Proposals for the immunological classification of acute leukaemias: European Group for the Immunological Characterization of Leukemias (EGIL) Leukemia 9: 17831786 .

9. Bessho F, Takayama N, Fronkova E, Zuna J. (2013). Reappearance of acute lymphoblastic leukemia 34 years after initial diagnosis: a case report and study of the origin of the reappeared blasts.Int $\mathrm{J}$ Hematol. 97(4): 525-528.

10. Bhatia S. (2013). Therapy-related myelodysplasia and acute myeloid leukemia. Semin Oncol. 40(6): 666-675.

11. Bien E, Stachowicz-Stencel T, Szalewska M, Krawczyk M, Synakiewicz A, Dubaniewicz-Wybieralska M et al. (2009). Poor-risk high-grade gliomas in three survivors of childhood acute lymphoblastic leukaemia - an overview of causative factors and possible therapeutic options. Childs Nerv Syst. 25(5): 619-626.

12. Bierings M, Szczepanski T, van Wering ER, Willemse MJ, Langerak AW, Revesz T et al. (2001). Two consecutive immunophenotypic switches in a child with immunogenotypically stable acute leukaemia. Br J Haematol. 113(3): 757-762.
13. Borowitz MJ, Bene M-C, Harris NL, Porwit A, Matutes E. (2008). Acute leukemias of ambiguous lineage. In: Swerdlow SH, Campo E, Harris NL, Jaffe ES, Pileri SA, Stein $\mathrm{H}$ et al., editors. WHO Classification of Tumours of Haematopoietic and Lymphoid Tissues. Geneva: WHO Press: 150-151.

14. Borowitz MJ, Chan JKC. (2008). B lymphoblastic leukaemia/lymphoma with recurrent genetic abnormalities. In: Swerdlow SH, Campo E, Harris $\mathrm{NL}$, Jaffe ES, Pileri SA, Stein $\mathrm{H}$ et al., editors. WHO Classification of Tumours of Haematopoietic and Lymphoid Tissues. Geneva: WHO Press: $171-175$

15. Borowitz MJ, Chan JKC. (2008). B lymphoblastic leukaemia/lymphoma, not otherwise specified. In: Swerdlow SH, Campo E, Harris NL, Jaffe ES, Pileri SA, Stein $\mathrm{H}$ et al., editors. WHO Classification of Tumours of Haematopoietic and Lymphoid Tissues. Geneva: WHO Press: 168-170.

16. Borowitz MJ, Chan JKC. (2008). T lymphoblastic leukemia/lymphoma. In: Swerdlow SH, Campo E, Harris NL, Jaffe ES, Pileri SA, Stein H et al., editors. WHO Classification of Tumours of Haematopoietic and Lymphoid Tissues. Geneva: WHO Press: 176-178.

17. Conter V, Bartram CR, Valsecchi MG, Schrauder A, Panzer-Grumayer R, Moricke $A$ et al. (2010). Molecular response to treatment redefines all prognostic factors in children and adolescents with B-cell precursor acute lymphoblastic leukemia: results in 3184 patients of the AIEOPBFM ALL 2000 study. Blood. 115: 3206-3214.

18. Donadieu J, Auclerc MF, Baruchel A et al. (1998). Critical study of prognostic factors in childhood acute lymphoblastic leukemia: differences in outcome are poorly explained by the most significant prognostic variables. FRALLE Group Frensh Acute Lymphoblastic Leukemia study group. Br.J.Haematol. 102: 729-739.

19. Dordelmann M, Reiter A, Borkhardt A, Ludwig WD. (1999). Prednisone response in the strongest predictor of treatment outcome in infant acute lymphoblastic leukemia. Blood. 94(4): 1209-1217.

20. Dreyer ZE, Hilden JM, Jones TL, Devidas M, Winick NJ, Willman CL et al. (2015). Intensified chemotherapy without SCT in infant ALL: results from COG P9407 (Cohort 3). Pediatr Blood Cancer. 62: 419-426.

21. Erduran E, Gedik Y, Orhan F et al. (1999). Brief report. Leukemic infiltrations of the peritoneum at diagnosis and the breast at relapse in a child with acute B-cell lymphoblastic leukemia. Med Pediatr Oncol. 32: $71-72$.

22. Fink FM, Koller $\mathrm{U}$, Mayer $\mathrm{H}$ et al. (1993). Prognostic significance of myeloid-associated antigen expression on blast cells in children with acute lymphoblastic leukemia. Med PediatrOncol. 21: $340-346$.

23. Firat $H$, Favier R, Adam M et al. (2001). Determination of myeloid antigen expression on childhood acute lymphoblastic leukaemia cells: discrepancies using different monoclonal antibody clones. Leuk Lymphoma. 42(4): 675-682.

24. Fisher KE, Hsu AP, Williams CL, Sayeed H, Merritt BY, Elghetany MT, Holland SM, Bertuch AA, Gramatges MM. (2017). Somatic mutations in chil- 
dren with GATA2-associated myelodysplastic syndrome who lack othe features of GATA2 deficiency. Blood Adv. 1(7): 443-448.

25. Griffin TC, Shuster JJ, Buchanan GR et al. (2000). Slow disapperarance of periferall blood blasts in as adverse prognostic factor in childhood T cell acute lymphoblastic leukemia: a Pedoatric Oncology Group study. Leukemia. 14(5): 792-795.

26. Haarman EG, Kaspers G-JP, Veerman AJP. (2003). Glucocorticoid resistence in childhood leuaemia: mechanisms and modulation. $\mathrm{Br} \mathrm{J}$ Haematol. 120(6): 919-929

27. Haddy TB, Mosher RB, Reaman GH. (2009). Late effects in long-term survivors after treatment for childhood acute leukemia. Clin Pediatr (Phila). 48(6): 601-608.

28. Hannson CA, Abaza M, Sheldon S et al. (1993). Acute biphenotypic leukemia: immunophenotypic and cytogenetic analysis. $\mathrm{Br} \mathrm{J}$ Haematol. 84(1): 49-60.

29. Howard MR, Thomas L, Reid MM. (1994). Variable detection antigen in childhood acute lymphoblastic leukemia. J Clin Patology. 47: $1006-1009$.

30. Hunger SP, Lu X, Devidas M, Camitta BM, Gaynon PS, Winick NJ et al. (2012). Improved survival for children and adolescents with acute lymphoblastic leukemia between 1990 and 2005: a report from the children's oncology group. J Clin Oncol. 30: 1663-1669.

31. Janka-Schaub GE, Stuhrk H, Kortam B et al. (1991). Initiales Ansprechen auf die Therapie als wichtigster prognostischer Factor bei der akuten lymphoblastischen Leukamia in Kindesalter. Klin. Padiatr. 203(4): 231-235.

32. Kachel L, Rudzka E, Krzemien S et al. (1995). Wznowy w osrodkowym ukladzie nerwowym w przebiegu ostrej bialaczki limfoblastycznej a sposob postepowania profilaktycznego. Acta Haematologica Polonica (Poland). 26(1): 47-56.

33. Karrman K, Johansson B. (2017). Pediatric T-cell acute lymphoblastic leukemia. Genes Chromosomes Cancer. 56(2): 89-116.

34. Khan M, Siddiqi R, Naqvi K. (2018). An update on classification, genetics, and clinical approach to mixed phenotype acute leukemia (MPAL). Ann Hematol. (Epub ahead of print).

35. Killick S, Matutes E, Powles RL, Hamblin M, Swansbury J, Treleaven JG et al. (1999). Outcome of biphenotypic acute leukemia. Haematologica. 84(8): 699-706.

36. Krawczuk-Rybak M, Zak J, Jaworowska B. (2003). A lineage switch from AML to ALL with persistent translocation $\mathrm{t}(4 ; 11)$ in congenital leukemia. Med Pediatr Oncol. 41(1): 95-96.

37. Kurec AS, Belair P, Stefanu C et al. (1991). Significance of aberrant immunophenotypes in childhood acute lymphoblastic leukemia. Cancer. 67: 3081.

38. Lawson SE, Harrison G, Richards S et al. (2000). The UK experience in treating relapsed childhood acute lymphoblastic leukemia: a report on the Medical Research Coucil UKALLR1 study. Br J Haematol. 108(3): 531-543.

39. Le Clerc JM, Billett AL, Gelber RD et al. (2002). Treatment of childhood acute lymphoblastic leukemia: result of Dana-Farber ALL Consorcium Protocol 87-01. J Clin Oncology. 20(1): 237-246.

40. Lee JW, Kim SK, Jang PS, Jeong DC, Chung NG, Cho B et al. (2016). Treatment of children with acute lymphoblastic leukemia with risk group based intensification and omission of cranial irradiation: A Korean study of 295 patients. Pediatr Blood Cancer. 63: 1966-1973.

41. Lee JW, Cho B. (2017). Prognostic factors and treatment of pediatric acute lymphoblastic leukemia. Korean $\mathrm{J}$ Pediatr. 60(5): 129-137.

42. Legrand O, Perrot JY, Simonin G et al. (1998). Adult biphenotypic acute leukemia: an ently with poor prognosis which is related to unfavorable cytogenetics and P-glycoprotein over-expression. $\mathrm{Br} \mathrm{J}$ Haematol. 100(1): $147-155$

43. Lo Coco F. (1991). Hybrid phenotypes and lineage promiscuity in acute leukemia. Haematologica. 76(3): 215-225.

44. Loning L, Zimmermann M, Reiter A et al. (2000). Secondary neoplasms subsequent to Berlin-Frankfurt-Munster therapy of acute lymphoblastic leukemia in childhood: significantly lower risk without cranial therapy. Blood. 95: 2770-2775.
45. Ludwig WD, Thiel E, Koller U et al. (1990). Incindence and clinical implications of acute hybrid leukemia in childhood. Haematol.Blood Transfus. (Acute Leukemias II): 516-522.

46. Madeja G. (1994). Chemioterapia onkologiczna doroslych i dzieci. Pod redakcja G. Madeja - Warszawa: Wydawnictwo Lekarskie PZWL: 315.

47. Matsuzaki A, Okamura J, Ishii E et al. (1999). Treatment of standard-risk acute lymphoblastic leukemia in children: The results of Protocol AL 841 from the Kyushu-Yamaguchi Children's Cancer Study Group in Japan. Pediatr Hematol Oncol. 16: 187-199.

48. Mejstrikova E, Kalina T, Trka J, Stary J, Hrusak O. (2005). Correlation of CD33 with poorer prognosis in childhood ALL implicates a potential of anti-CD33 frontline therapy. Leukemia. 19(6): 1092-1094.

49. Mejstrikova E, Volejnikova J, Fronkova E, Zdrahalova K et al. (2010). Prognosis of children with mixed phenotype acute leukemia treated on the basis of consistent immunophenotypic criteria. Haematologica. 95(6): 928-935.

50. Mi Y, Bian S, Meng Q et al. (2000). Study on the clinical characteristics of biphenotypic acute leukemia. Zhonghua Xue Ye Za Zhi. 21(7): 352-354.

51. Miller RW, Young JL, Novakovic B. (1995). Childhood cancer. Cancer. 75: 395-405.

52. Moricke A, Zimmermann M, Reiter A, Henze G, Schrauder A, Gadner H et al. (2010). Long-term results of five consecutive trials in childhood acute lymphoblastic leukemia performed by the ALL-BFM study group from 1981 to 2000. Leukemia. 24: 265-284.

53. Nachman JB, Heerema NA, Sather $\mathrm{H}$ et al. (2007). Outcome of treatment in children with hypodiploid acute lymphoblastic leukemia. Blood. 110: $1112-1115$.

54. Neglia JP, Friedman DL, Yasui Y et al. (2001). Second Malignant Neoplasms in Five-Year Survivors of Childhood Cancer: Childhood Cancer Survivor Study. JNCl J Natl Cancer Inst. 93(8): 618-629.

55. Neglia JP, Meadows AT, Robison LL et al. (1991). Second neoplasms after acute lymphoblastic leukemia in childhood. $\mathrm{N}$ Engl $\mathrm{J}$ Med. 325(19): 1330-1336.

56. Neglia JP, Robison LL, Stovall M et al. (2006). New Primary Neoplasms of the Central Nervous System in Survivors of Childhood Cancer: a Report From the Childhood Cancer Survivor Study. JNCl J Natl Cancer Inst. 98(21): 1528-1537.

57. Ng SM, Ariffin WA, Lin HP et al. (2000). Clinical features and treatment outcome of children with myeloid antigen coexpression in B-lineage acute lymphoblastic leukemia: a study of 151 Malaysian children. J Trop Pediatr. 46(2): 73-78.

58. Nielsen SN, Eriksson F, Rosthoej S, Andersen MK, Forestier E, Hasle H, Hjalgrim LL, Aasberg A, Abrahamsson J, Heyman M, Jonsson OG, Pruunsild K, Vaitkeviciene GE, Vettenranta K, Schmiegelow K. (2017). Children with low-risk acute lymphoblastic leukemia are at highest risk of second cancers. Pediatr Blood Cancer. 64(10).

59. Otsubo K, Yabe M, Yabe H, Fukumura A, Morimoto T, Kato M, Mochizuk H. (2016). Successful acute lymphoblastic leukemia-type therapy in two children with mixed-phenotype acute leukemia. Pediatr Int. 58(10): 1072-1076.

60. Owaidah TM, Al Beihany A, lqbal MA, Elkum N, Roberts GT. (2006). Cytogenetics, molecular and ultrastructural characteristics of biphenotypic acute leukemia identified by the EGIL scoring system. Leukemia. 20(4): 620-626.

61. Pieters R, Schrappe M, De Lorenzo P, Hann I, De Rossi G, Felice M et al. (2007). A treatment protocol for infants younger than 1 year with acute lymphoblastic leukaemia (Interfant-99): an observational study and a multicentre randomised trial. Lancet. 370: 240-250.

62. Pituch-Noworolska A, Gawlicka M, Balwierz Wet al. (1997). Atypical phenotypes of leukemic cells in acute leukaemia in children. Acta Haematologica Polonica (Poland). 28(1): 53-63.

63. Pui CH, Campana D, Pei D, Bowman WP, Sandlund JT, Kaste SC et al. (2009). Treating childhood acute lymphoblastic leukemia without cranial irradiation. N Engl J Med. 360: 2730-2741.

64. Pui CH, Raimondi SC, Head DR et al. (1991). Characterization of childhood acute lymphoblastic leukemia with multiple 
myeloid and lymphoid markers at diagnosis and relaps. Blood. 78 1327-1337.

65. Pui $\mathrm{CH}$, Yang JJ, Hunger SP, Pieters R, Schrappe M, Biondi A et al. (2015). Childhood Acute Lymphoblastic Leukemia: Progress Through Collaboration. J Clin Oncol. 33(27): 2938-2948.

66. Pui CH. (1998). Acute lymphoblastic leukemia. N Engl J Medicine. 339(9): 605-615.

67. Putti MC, Rondelli R, Cocoto MG et al. (1998). Expression of myeloid markers lacks prognostic impact in children treated for acute lymphoblastic leukemia: Italian experience in AIEOP-ALL 88-91 stidies. Blood. 92: 795-801.

68. Reiter A, Schrappe M, Ludwig WD et al. (1994). Chemotherapy in 998 unselected childhood acute lymphoblastic leukemia patients. Result and conclusions of the multicenter trial ALL-BFM 86. Blood. 84: 3122-3133.

69. Riehm H, Reiter A, Schrappe M et al. (1987). Corticosteroid-dependent reduction of leucocyte count in blood as a prognostic factor in acute lymphoblastic leukemia in childhood (therapy study ALL-BFM 83). Klinische Padiatrie. 199: 151-160.

70. Rihani R, Bazzeh F, Faqih N, Sultan I. (2010). Secondary hematopoietic malignancies in survivors of childhood cancer: an analysis of 111 cases from the Surveillance, Epidemiology, and End Result-9 registry. Cancer. 116(18): 4385-4394

71. Rubnitz JE, Onciu M, Pounds S, Shurtleff S, Cao X, Raimondi SC et al (2009). Acute mixed lineage leukemia in children: the experience of St Jude Children's Research Hospital. Blood. 113(21): 5083-5089.

72. Salek C, Folber F, Fronkova E, Prochazka B, Marinov I, Cetkovsky P, Mayer J, Doubek M; Czech Leukemia Study Group - for Life. (2016). Early MRD response as a prognostic factor in adult patients with acute lymphoblastic leukemia. Eur J Haematol. 96(3): 276-284.

73. Schmiegelow K, Levinsen MF, Attarbaschi A, Baruchel A, Devidas M et al. (2013). Second malignant neoplasms after treatment of childhood acute lymphoblastic leukemia. J Clin Oncol. 31(19): 2469-2476.

74. Schrappe M, Reiter A, Sauter S und andere. (1994). Konzeption und Zwischenergebnis der Therapiestudie ALL-BFM 90 zur Behandlung der akuten lympphoblastischen Leukamie bei Kindern und Jugendlichen: Die Behandlung des initialen Therapieansprechens in Blut und Knochenmark. Klin Padiatr. 206: 208-221.

75. Schrappe M, Reiter A, Zimmermann M et al. (2000). Long-term result of four consecutiwve trials in childhood ALL perfomed by the ALL-BFM study group from 1981 to 1995 . Berlin-Frankfurt-Munster. Leukemia. 14(12): 2205-2222

76. Schrappe M, Valsecchi MG, Bartram CR, Schrauder A, Panzer-Grumayer R, Moricke $A$ et al. (2011). Late MRD response determines relapse risk overall and in subsets of childhood T-cell ALL: results of the AIEOPBFM-ALL 2000 study. Blood. 118: 2077-2084.

77. Stary J, Zimmermann M, Campbell M, Castillo L et al. (2014). Intensive Chemotherapy for Childhood Acute Lymphoblastic Leukemia: Results of the Randomized Intercontinental Trial ALL IC-BFM 2002. J Clin Oncol. 32: $174-185$

78. Stiller CA, Parkin DM. (1996). Geographic and ethnic variations in the incidence of childhood cancer. Br Med Bull. 52: 682-703.

79. Theunissen P, Mejstrikova E, Sedek L, van der Sluijs-Gelling AJ, Gaipa G, Bartels M, Sobral da Costa E, Kotrova M et al.; EuroFlow Consortium. (2017). Standardized flow cytometry for highly sensitive MRD measurements in B-cell acute lymphoblastic leukemia. Blood. 129(3): 347-357.

80. Trigg ME, Steinherz PG, Chappell R et al. (2000). Early testicular biopsy in males with acute lymphoblastic leukemia: lack of impact on subsequent event-free survival. J Pediatr Hematol Oncol. 22(1): 27-33.

81. Tsuruchi N, Okamura J. (1996). Childhood acute lymphoblastic leukemia relapse in the uterine cervix. J Pediatr Hematol Oncol. 18(3): 311-313.

82. Tzortzatou-Stathopoulou F, Papadopoulou AL, Moschovi M, Botsonis A, Tsangaris GT. (2001). Low relapse rate in children with acute lymphoblastic leukemia after risk-directed therapy. J Pediatr Hematol Oncol. 23(9): 591-597.

83. Uckun FM, Sather HN, Gaynon PS. (1997). Clinical features and treatment outcome of children with myeloid antigen positive acute lymphoblastic leukemia: a report from the Children's Cancer Group. Blood. 90(1): $28-35$

84. Volejnikova J, Mejstrikova E, Valova T, Reznickova L, Hodonska L, Miha V, Sterba J, Jabali Y, Prochazkova D, Blazek B, Hak J, Cerna Z, Hrusak O, Stary J, Trka J, Fronkova E. (2011). Minimal residual disease in peripheral blood at day 15 identifies a subgroup of childhood B-cell precursor acute lymphoblastic leukemia with superior prognosis. Haematologica. 96(12): 1815-1821.

85. Vora A, Andreano A, Pui CH, Hunger SP, Schrappe M, Moericke A, Biondi A et al. (2016). Influence of Cranial Radiotherapy on Outcome in Children with Acute Lymphoblastic LeukemiaTreated with Contemporary Therapy. J Clin Oncol. 34(9): 919-926.

86. Vrooman LM, Neuberg DS, Stevenson KE, Asselin BL, Athale UH, Clavell L et al. (2011). The low incidence of secondary acute myelogenous leukaemia in children and adolescents treated with dexrazoxane for acute lymphoblastic leukaemia: a report from the Dana-Farber Cancer Institute ALL Consortium. Eur J Cancer. 47(9): 1373-1379.

87. Weir EG, Ali Ansari-Lari M, Batista DA, Griffin CA, Fuller S, Smith BD et al. (2007). Acute bilineal leukemia: a rare disease with poor outcome. Leukemia. 21(11): 2264-2270.

88. Weir EG, Borowitz MJ. (2001). Flow cytometry in the diagnosis of acute leukemia. Semin Hematol. 38(2): 124-138.

89. Wiersma S, Ortega J, Sobel E et al. (1991). Clinical importance of myeloid antigen expression in acute lymphoblastic leukemia of childhood. N Engl J Med. 324: 800-808.

90. Yeoh AE, Ariffin H, Chai EL, Kwok CS, Chan YH, Ponnudurai $\mathrm{K}$ et al. (2012). Minimal residual disease-guided treatment deintensification for children with acute lymphoblastic leukemia: results from the MalaysiaSingapore acute lymphoblastic leukemia 2003 study. J Clin Oncol. 30: 2384-392.

\section{Сведения об авторах:}

Дорош Ольга Игоревна - к.мед.н., врач-гематолог детский отделения гематологии и интенсивной химиотерапии и отделения консультативной поликлиники Коммунального некоммерческого предприятия Львовского областного совета «Западноукраинский специализированный детский медицинский центр». Адрес: г. Львов, ул. Днестровская, 27 . цимбалюк-Волошин Ирина Петровна - К.мед.н., зав. отделения гематологии и интенсивной химиотерапии и анестезиолог отделения анестезиологии и интенсивной терапии Комсфузионной медицины ФПДО Львовского НМУ имени Д. Галицкого. Адрес: г. Львов, ул. Днестровская, 27.

Бодак Христина Игоревна - врач-гематолог детский отделения гематологии и интенсивной химиотерапии Коммунального некоммерческого предприятия Львовского областного совета «Западноукраинский специализированный детский медицинский центр». Адрес: г. Львов, ул. Днестровская, 27.

Полищук Романа Степановна - к.мед.н., врач-гематолог детский отделения гематологии и интенсивной химиотерапии и отделения консультативной поликлиники Коммунального некоммерческого предприятия Львовского областного совета «Западноукраинский специализированный детский медицинский центр». Адрес: г. Львов, ул. Днестровская, 27. Степанюк Алла Ивановна - врач-гематолог детский отделения гематологии и интенсивной химиотерапии и анестезиолог отделения анестезиологии и интенсивной терапии Коммунального некоммерческого предприятия Львовского областного совета «Западноукраинский специализированный детский медицинский центр». Адрес: г. Львов, ул. Днестровская, 27. совета «Западноукраинский специализированный детский медицинский центр». Адрес: г. Львов, ул. Днестровская, 27.

Скоропад Лариса Львовна - врач-гематолог детский отделения гематологии и интенсивной химиотерапии и отделения консультативной поликлиники Коммунального некоммерческого предприятия Львовского областного совета «Западноукраинский специализированный детский медицинский центр». Адрес: г. Львов, ул. Днестровская, 27. Трояновськая Ольга Орестовна - к.мед.н., ассистент каф. педиатрии Львовского НМУ имени Д. Галицкого, врач-гематолог детский отделения гематологии и интенсивной химиотезированный детский медицинский центр». Адрес: г. Львов, ул. Днестровская, 27.

Козлова Елена Игоревна - врач-гематолог детский отделения гематологи и интенсивной химиотерапии Коммунального некоммерческого предприятия Львовского областного совета «Западноукраинский специализированный детский медицинский центр». Адрес: г. Львов, ул. Днестровская, 27.

Мих Алла Николаевна - врач-цитолог клинической лаборатории Коммунального некоммерческого предприятия Львовского областного совета «Западноукраинский специализированный детский медицинский центр». Адрес: г. Львов, ул. Днестровская, 27; Медицинский центр Святой Параскевы. Адрес: г. Львов, ул. Заводская, 7.

Середич Лилия Петровна - врач-цитолог клинической лаборатории Коммунального некоммерческого предприятия Львовского областного совета «Западноукраинский специализированный детский медицинский центр». Адрес: г. Львов, ул. Днестровская, 27.

Глинськая Оксана Владимировна - зав. отделения клинической лаборатории Коммунального некоммерческого предприятия Львовского областного совета «Западноукраинский спеСтатья поступила в редакцию 02.08.2018 г., принята к печати 04.12.2018 г. 


\title{
І.А. Косаківська \\ Досвід виконання аденотомії у дітей
}

\author{
Національна академія післядипломної освіти імені П.Л. Шупика, м. Київ, Україна \\ SOVREMENNAYA PEDIATRIYA.2018.8(96):37-41; doi 10.15574/SP.2018.96.37
}

\begin{abstract}
Аденотомія $€$ найпоширенішим хірургічним втручанням у дітей. Найчастішими ускладненнями аденотомії є кровотеча та рецидиви захворювання. Мета: підвищення ефективності аденотомії у дітей.

Матеріали і методи. Під спостереженням перебували 183 дитини віком від 2 до 15 років з аденоїдними вегетаціями. Дівчаток було 85, хлопчиків 98. Аденоїдні вегетації II ступеня мали місце у 27,3\%, III ступеня - у 72,7\% дітей. У 2,7\% хворих лімфоїдна тканина з носоглотки поширювалась через хоани в порожнину носа. В основній групі було 146 дітей, у контрольній - 37. Для видалення аденоїдних вегетацій використовували біполярні аденотоми, а гемостаз у післяопераційній рані проводили за допомогою біполярних електропристроїв власної конструкції.

Результати. Хірургічне лікування проведено усім дітям. При аденотомії за традиційною методикою (контрольна група) інтраопераційна крововтрата становила 26,24 1,737 мл, а при використанні високочастотного струму (основна група) $-3,36 \pm 0,233$ мл ( $<<0,001$ ). Запропонована нами техніка хірургічного лікування хронічних хвороб лімфоглоткового кільця у дітей дозволила відновити фізіологічне дихання у всіх випадках. Застосування електротермоадгезії залишків аденоїдних вегетацій дозволило відновити просвіт хоан, уникнути рецидиву захворювання та зберегти невелику частину глоткового мигдалика, що важливо для відновлення його функції.

Висновки. Методика аденотомії у дітей з використанням електрозварювальної технології живих біологічних тканин дозволяє відновити фізіологічне дихання, значно зменшити інтраопераційну крововтрату, запобігти післяопераційній кровотечі, відновити або покращити слух та уникнути рецидиву захворювання у всіх випадках, що свідчить про високу її ефективність.
\end{abstract}

Ключові слова: діти, аденоїдні вегетації, лікування.

\section{Experience in the implementation of adenotomy in children IA. Kosakivska}

Shupyk National Medical Academy of Postgraduate Education, Kyiv, Ukraine

Introduction. Adenotomy is the most common surgical intervention in children. The most common complications of adenotomy are bleeding and recurrence of the disease.

The aim of the study was to increase the effectiveness of adenotomy in children.

Material and methods. Under our supervision in the clinic, there were 183 children with adenoidal vegetations aged 2 to 15 years. The girls were 85 , boys 98. The adenoidal vegetations of the II degree took place at $27.3 \%$, the III degree $-72.7 \%$. In $2.7 \%$ of the lymphoid tissue from the nasopharynx spread through the hoans into the nasal cavity. In the main group there were 146 children, in the control group - 37 . To remove adenoid vegetations, bipolar adenomas were used, and hemostasis in the postoperative wound was performed using bipolar electrodes of its own design.

Results and discussion. Surgical treatment was performed in 183 children with adenoid vesicles. In adenotomy, according to the traditional method (control group), intraoperative blood loss was $26.24 \pm 1.737 \mathrm{ml}$, while using high-frequency current (main group) $-3.36 \pm 0.233 \mathrm{ml}(\mathrm{p}<0.001)$. The proposed technique of surgical treatment of chronic diseases of the lymphocyte ring in children allowed us to restore physiological respiration in all cases. The use of electrothermagazies of the adenoid vegetation residues allowed to restore the lumen of the chicken, to avoid recurrence of the disease and to preserve a small part of the pharyngeal tonsil, which is important for the restoration of its function.

Conclusions. The technique of adenotomy in children using the electric welding technology of living biological tissues can restore physiological respiration, significantly reduce intraoperative blood loss, prevent post-operative bleeding, restore or improve hearing, and avoid recurrence of the disease in all cases, which indicates its high effectiveness.

Key words: children, adenoid vegetations, treatment.

\section{Опыт выполнения аденотомии у детей \\ и.А. Косаковская}

Национальная академия последипломного образования имени П.Л. Шупика, г. Киев, Украина

Аденотомия является самым распространенным хирургическим вмешательством у детей. Наиболее частыми осложнениями аденотомии являются кровотечение и рецидивы заболевания.

Цель: повышение эффрективности аденотомии у детей.

Материалы и методы. Под наблюдением в клинике находилось 183 ребенка с аденоидными вегетациями в возрасте от 2 до 15 лет. Девочек было 85 , мальчиков - 98. Аденоидные вегетации II степени имели место у $27,3 \%$, III степени - у 72,7\% детей. У 2,7\% больных лимсоидная ткань из носоглотки распространялась через хоаны в полость носа. В основной группе было 146 детей, в контрольной - 37. Для удаления аденоидных вегетаций использовали биполярные аденотомы, а гемостаз в послеоперационной ране проводили с помощью биполярных электроустройств собственной конструкции.

Результаты. Хирургическое лечение было проведено всем детям. При аденотомии по традиционной методике (контрольная группа) интраоперационная кровопотеря составила 26,24ะ1,737 мл, а при использовании высокочастотного тока (основная группа) $-3,36 \pm 0,233$ мл $(p<0,001)$. Предложенная нами техника хирургического лечения хронических болезней лимфоглоточного кольца у детей позволила восстановить физиологическое дыхание во всех случаях. Применение электротермоадгезии остатков аденоидных вегетаций позволило восстановить просвет хоан, избежать рецидива заболевания и сохранить небольшую часть глоточной миндалины, что важно для восстановления ее функции.

Выводы. Методика аденотомии у детей с использованием электросварочной технологии живых биологических тканей позволяет восстановить фризиологическое дыхание, значительно уменьшить интраоперационную кровопотерю, предотвратить послеоперационное кровотечение, восстановить или улучшить слух и избежать рецидива заболевания во всех случаях, что свидетельствует о высокой ее эффективности.

Ключевые слова: дети, аденоидные вегетации, лечение. 


\section{Вступ}

денотомія є найпоширенішим хірургічним втручанням у дітей $[11,12]$. Основоположником аденотомії є В. Меєр, який вперше у 1868 році в Копенгагені успішно провів операцію за допомогою власних кільцеподібних щипців, введених через ніс і хоани до склепіння носової частини глотки $[14,15]$. Починаючи з 1930-х років, ця операція стала виконуватися рутинно з використанням кільцеподібного ножа (аденотом Бекмана) 3 доступом через ротову порожнину [2]. У подальшому аденоїдні вегетації стали видаляти під візуальним контролем [16].

Слід зазначити, що одним 3 найчастіших ускладнень виконаної таким чином аденотомії $\mathrm{\epsilon}$ кровотеча, як під час операції, так і в післяопераційний період, та рецидиви захворювання $[1,13]$.

Метою дослідження було підвищення ефективності аденотомії у дітей.

\section{Матеріал і методи дослідження}

Під нашим спостереженням у клініці знаходилися 183 дитини з аденоїдними вегетаціями віком від 2 до 15 років. Дівчаток було 85, хлопчиків - 98. Аденоїдні вегетації II ступеня мали місце у 27,3\%, III ступеня у 72,7\%. У 2,7\% лімфоїдна тканина з носоглотки поширювалась через хоани у порожнину носа, причому у одного пацієнта аденоїдні вегетації поширюються у порожнину носа на 3 см. В основній групі було 146 дітей, у контрольній -37 .

Секреторний середній отит виявлено у $50(27,3 \%)$ пацієнтів. Типанограма С була у 18 пацієнтів (30 вух), тимпанограма В виявлена у 32 дітей (59 вух).

Гіпертрофія піднебінних мигдаликів II-III ступеня мала місце у 76 (41,5\%), хронічний тонзиліт - у 21 (11,5\%) пацієнта.

Усі діти були прооперовані під ендотрахеальним наркозом. Крововтрату під час операції оцінювали у мілілітрах, біль - за 10-бальною візуально-аналоговою шкалою (ВАШ), клінічні прояви (гіперемія, набряк слизової оболонки, фібринозні нашарування) за 3-бальною шкалою. Термін спостереження становив від 1 місяця до 5 років.

Дослідження виконані відповідно до принципів Гельсінської Декларації. Протокол дослідження ухвалений Локальним етичним комітетом (ЛЕК) установи. На проведення досліджень було отримано поінформовану згоду батьків дітей (або їхніх опікунів).
На початку дослідження аденоїдні вегетації видаляли за допомогою аденотома Бекмана відповідного розміру під візуальним контролем з використанням гортанного дзеркала або ендоскопа $70^{\circ}$. За необхідності, що було зумовлено особливостями архітектоніки носоглотки у конкретного пацієнта, для видалення залишків лімфоїдної тканин використовували аденотом Бекмана №0. При локалізації аденоїдних вегетацій у хоанах і порожнині носа лімфоїдну тканину видаляли аденотомом фірми «Шторц» №0 або через порожнину носа за допомогою гортанних щипців з набору Кляйнзасера. М'яке піднебіння під час операції відводили від задньої стінки глотки за допомогою еластичних катетерів. Гемостаз проводили шляхом тампонади носоглотки широким марлевим тампоном. Під час операції користувались роторозширювачем власної конструкції $[7,10]$.

У подальшому нами була удосконалена техніка аденотомії. Для фіксації м'якого піднебіння було запропоновано відповідний пристрій (рис. 1) [6]. За допомогою даного пристрою м'яке піднебіння надійно фіксується в заданому положенні і забезпечує доступ до носоглотки.

Для видалення аденоїдних вегетацій використовували біполярні аденотоми власної кон-

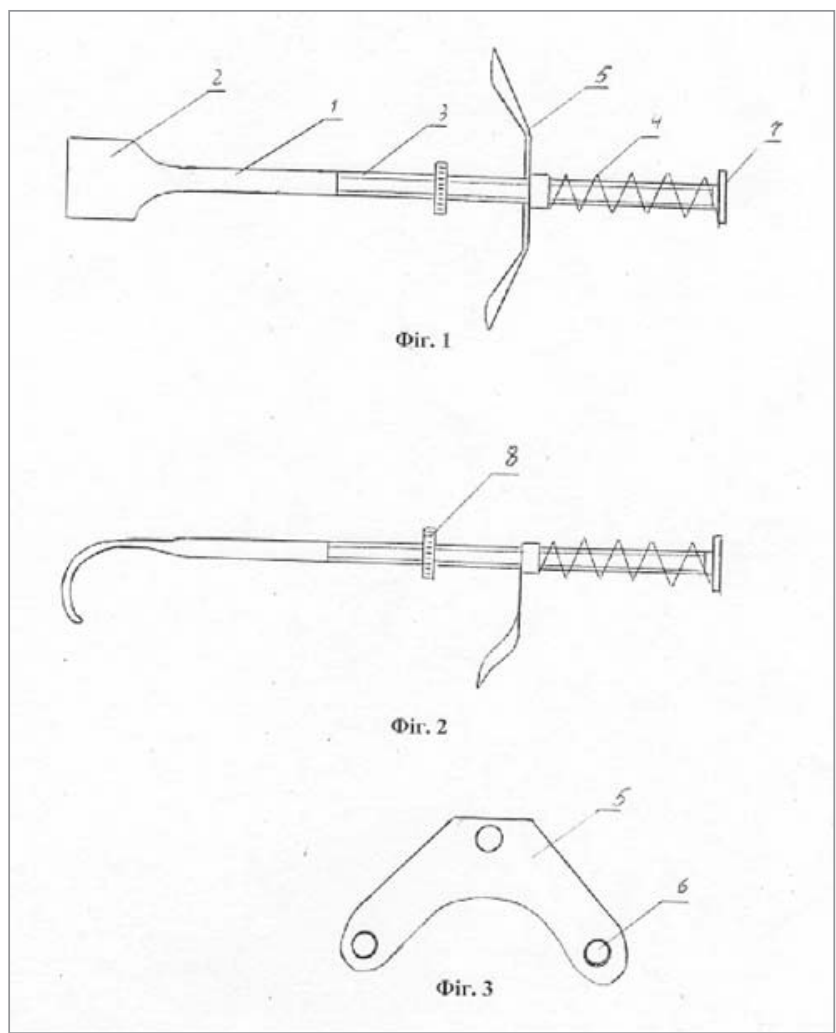

Pис. 1. Схематичне зображення пристрою для фріксації м'якого піднебіння 


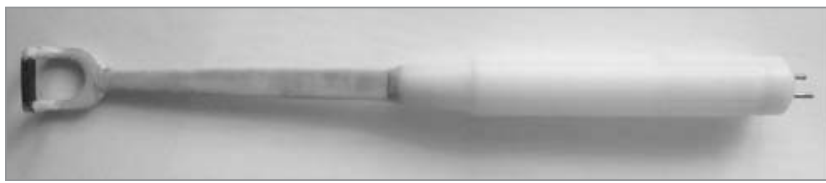

Pис. 2. Біполярний аденотом А.Л. Косаковського

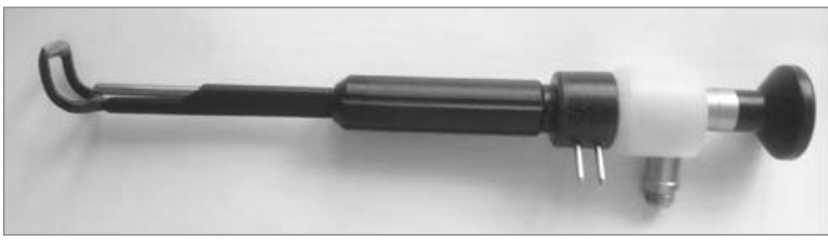

Pис. 3. Біполярний аденотом Косаковського-Семенова з ендоскопом

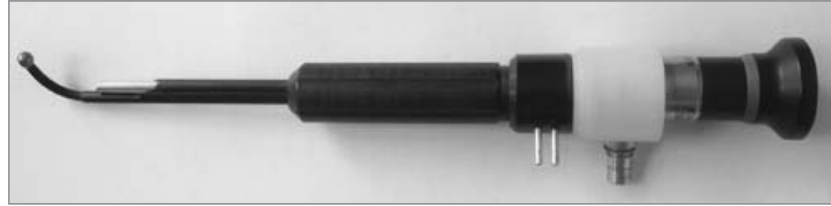

Pис. 4. Оптичний біполярний електропристрій для коагуляції тканин

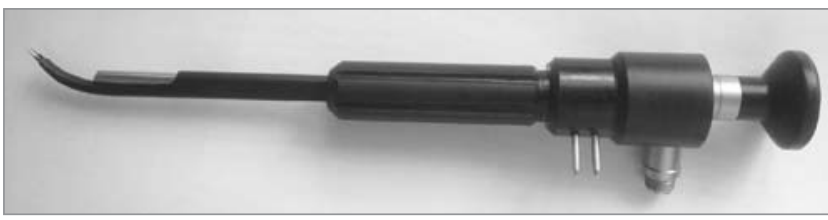

Pис. 5. Біполярний пристрій для коагуляції з ендоскопом

струкції (патенти України на винахід № 91640, № 96641) [8,9] (рис. 2, 3).

Конструктивною особливістю запропонованих аденотомів була наявність біполярного леза, що забезпечувало одночасне видалення лімфоїдної тканини та гемостаз.

При видаленні аденоїдних вегетацій аденотомом А.Л. Косаковського візуальний контроль за операційним полем проводили за допомогою гортанного дзеркала, а при використанні аденотома Косаковського-Семенова зображення операційного поля виводилось на монітор ендоскопічної стійки.

Гемостаз у післяопераційній рані проводили за допомогою біполярних електропристроїв власної конструкції. При візуальному контролі за допомогою гортанного дзеркала електротермоадгезію (ETA) у рані проводили з використанням високочастотного біполярного електропристрою для коагуляції тканин власної конструкції (патент України на винахід № 99043) [3].

У подальшому був розроблений оптичний біполярний електропристрій для коагуляції тканин (патент України на корисну модель № 113320) [4]. На рис. 4 показано загальний вид даного електропристрою.

Конструктивною особливістю цих пристроїв є біполярний електрод, який виконано у формі «інь-янь». Така форма дозволяє проводити коагуляцію тканин при контакті з будьякою ділянкою кулькоподібного біполярного електрода.

Даний пристрій також використовували для видалення залишків лімфоїдної тканини в носоглотці та в хоанах.

При значній гіпертрофії трубних валиків у пацієнтів із секреторним середнім отитом нами використовувався біполярний пристрій для коагуляції з ендоскопом (патент України на корисну модель № 114693) [5] (рис. 5).

Пристрій для коагуляції складається з робочої частини з біполярним електродом, рукоятки у формі порожнистого циліндра та ендоскопа, причому біполярний електрод виконано у вигляді двох штирів циліндричної форми із загостреними дистальними кінцями, розташованими паралельно на відстані 2-4 мм між ними.

Після під'єднання пристрою для коагуляції до ендоскопічної стійки та джерела струму, робочу частину пристрою вводили під візуальним контролем у носоглотку до гіпертрофованих трубних валиків. При контакті біполярного електрода пристрою 3 валиками загострені штирі вводили в середину тканини і подавали високочастотний струм. Після розігрівання біполярного електрода відбувався процес ЕТА, що призводило у подальшому до зменшення їх об'єму та збільшення просвіту вустя слухової труби. Наявність ендоскопа у середині пристрою забезпечувало якісний візуальний контроль за операційним полем на моніторі ендоскопічної стійки. За наявності гіпертрофованих бокових валиків або задніх кінців нижніх носових раковин аналогічно проводили ЕТА гіпертрофованих ділянок.

У післяопераційний період для знеболення дітям призначали нестероїдний протизапальний препарат. У стаціонарі після аденотомії діти спостерігалися протягом доби. Після виписки зі стаціонару дитина упродовж семи днів перебувала під спостереженням дитячого отоларинголога за місцем проживання. Протягом місяця діти звільнялись від фізкультури.

\section{Результати дослідження та їх обговорення}

Хірургічне лікування було проведено у 183 дітей 3 аденоїдними вегетаціями. 146 пацієнтів склали основну групу, 37 контрольну групу. Перелік хірургічних втручань представлено в таблиці 1.

У 183 прооперованих пацієнтів було виконано 380 операцій, оскільки у частини дітей вико- 
Таблиия 1

Перелік оперативних втручань у дітей з аденоїдними вегетаціями та супутньою патологією

\begin{tabular}{|l|c|c|}
\hline \multirow{2}{*}{ Вид хірургічного втручання } & \multicolumn{2}{|c|}{ Кількість пацієнтів } \\
\cline { 2 - 3 } & $\begin{array}{c}\text { Основна } \\
\text { група }\end{array}$ & $\begin{array}{c}\text { Контрольна } \\
\text { група }\end{array}$ \\
\hline Аденотомія & 146 & 37 \\
\hline Тонзилотомія & 14 & 21 \\
\hline Тонзилопластика & 17 & - \\
\hline $\begin{array}{l}\text { Електротермоадгезія } \\
\text { піднебінних мигдаликів }\end{array}$ & 24 & - \\
\hline Тонзилектомія & 19 & 2 \\
\hline $\begin{array}{l}\text { Електротермоадгезія нижніх } \\
\text { носових раковин }\end{array}$ & 12 & 3 \\
\hline Септопластика & 9 & 5 \\
\hline $\begin{array}{l}\text { Електротермоадгезія } \\
\text { бокових валиків }\end{array}$ & 6 & - \\
\hline $\begin{array}{l}\text { Електротермоадгезія } \\
\text { трубних валиків }\end{array}$ & 2 & - \\
\hline Видалення кісти Торнвальда & 1 & - \\
\hline $\begin{array}{l}\text { Видалення ангіоматозного } \\
\text { поліпа носоглотки }\end{array}$ & - & 1 \\
\hline Видалення хоанального поліпа & - & 3 \\
\hline $\begin{array}{l}\text { Видалення синехій } \\
\text { порожнини носа }\end{array}$ & 1 & - \\
\hline Ендоназальна гайморотомія & - & 2 \\
\hline Сфенотомія & 2 & - \\
\hline Видалення кісти спинки носа & 1 & - \\
\hline Тимпанопункція & 41 & 9 \\
\hline Видалення папілом гортані & 297 & - \\
\hline Усього & & \\
\hline
\end{tabular}

нувались поєднані хірургічні втручання. Інтраопераційних ускладнень, за винятком кровотечі в окремих випадках, не було.

Під час аденотомії відмічено значне зменшення інтраопераційної крововтрати. При аденотомії за традиційною методикою (контрольна група) інтраопераційна крововтрата становила 26,24 1,737 мл, а при використанні високочастотного струму (основна група) $3,36 \pm 0,233$ мл ( $<<0,001)$, тобто крововтрата при використанні високочастотного струму зменшилась у 7,8 разу. У післяопераційний період у пацієнтів, у яких використовували запропоновану методику, кровотеча не спостерігалась, в той час як при використанні традиційної методики аденотомії вона мала місце у 7 (18,9\%) випадках. Причому у чотирьох випадках кровотечу зупиняли за допомогою біполярної коагуляції, а в одному випадку виконували тампонаду носоглотки і порожнини носа.

Подальше спостереження за пацієнтами проводилось після виписки із стаціонару через 1 тиждень, 1 місяць, 6 місяців і до 5 років. У всіх пацієнтів після аденотомії у перший тиждень мали місце помірні виділення слизу. Носове
Таблиия 2

Захворювання лімфаденоїдного глоткового кільця та супутня патологія у дітей до і після хірургічного лікування

\begin{tabular}{|l|c|c|c|c|}
\hline \multirow{2}{*}{ Захворювання та симптоми } & \multicolumn{4}{l}{ Кількість пацієнтів } \\
\cline { 2 - 6 } & \multicolumn{2}{|c|}{$\begin{array}{c}\text { До } \\
\text { ліку- } \\
\text { вання }\end{array}$} & $\begin{array}{c}\text { Після } \\
\text { ліку- } \\
\text { вання }\end{array}$ \\
\cline { 2 - 6 } & абс. & $\%$ & абс. & $\%$ \\
\hline Аденоїдні вегетації II-III ст., аденоїдит & 146 & 100 & - & - \\
\hline Гіпертрофрія піднебінних мигдаликів II ст. & 22 & 15,1 & 1 & 0,7 \\
\hline Гіпертрофрія піднебінних мигдаликів III ст. & 33 & 22,6 & - & - \\
\hline Хронічний тонзиліт & 19 & 13 & - & - \\
\hline Хронічний гіпертрофічний риніт & 6 & 4,1 & - & - \\
\hline Вазомоторний риніт & 1 & 0,7 & - & - \\
\hline Алергічний риніт & 5 & 3,4 & 5 & 3,4 \\
\hline Синехії порожнини носа & 1 & 0,7 & - & - \\
\hline Викривлення перегородки носа & 9 & 6,2 & - & - \\
\hline Кіста основної пазухи & 2 & 1,4 & - & - \\
\hline Кіста спинки носа & 1 & 0,7 & - & - \\
\hline Кіста Торнвальда & 1 & 0,7 & - & - \\
\hline Секреторний середній отит & 43 & 29,5 & 8 & 5,5 \\
\hline Храп під час сну & 65 & 44,5 & - & - \\
\hline Юнацький папіломатоз гортані & 2 & 1,4 & & \\
\hline
\end{tabular}

дихання покращувалось 3 першого дня після операції, відновлювалось - упродовж тижня. Причому швидше носове дихання відновлювалось у дітей, які були прооперовані з використанням ЕTА. Вибіркове ринопневмографічне дослідження оперованих дітей підтвердило відновлення носового дихання.

Динаміка захворювань до і після хірургічного лікування дітей основної групи із захворюваннями лімфаденоїдного глоткового кільця (спостереження від 1 до 5 років) наведена в табл. 2. 3 таблиці видно, що після хірургічних втручань 3 використанням методики електрозварювання живих біологічних тканин рецидивів аденоїдних вегетацій не виявлено. Лише у 1 з 55 пацієнтів спостерігали рецидив гіпертрофії піднебінних мигдаликів II ступеня. Кількість секреторних отитів зменшилась з 43 до 8. Позитивним є той факт, що після підслизової ЕТА нижніх носових раковин мало місце відновлення носового дихання не тільки у дітей $з$ хронічним гіпертрофічним та вазомоторним ринітом, але й з алергічним ринітом.

До операції у 65 (44,5\%) дітей спостерігалось хропіння під час сну. У післяопераційний період хропіння у дітей зникло. Запропонована нами техніка хірургічного лікування хронічних хвороб лімфоглоткового кільця у дітей дозволила відновити фізіологічне дихання у всіх випадках, що свідчить про високу ефективність проведеного оперативного лікування. Саме 
застосування ЕТА залишків аденоїдних вегетацій дозволяє відновити просвіт хоан, уникнути рецидиву захворювання та зберегти невелику частину глоткового мигдалика, що важливо для відновлення його функції.

Усі діти були прооперовані нами під загальною анестезією. Ускладнень, пов'язаних з проведенням ендотрахеальної наркозу, не зареєстровано.

Використання запропонованого нами пристрою для фіксації м'якого піднебіння забезпечує доступ до носоглотки під час оперативного втручання та візуальний контроль з боку ротової порожнини. При цьому виключається травмування язичка аденотомом та під час використання електровідсмоктувача. Відмова від катетеризації порожнини носа виключає розвиток реактивного набряку слизової оболонки, дозволяе проводити ендоскопічне втручання трансназально в повному обсязі та пришвидшуе відновлення носового дихання у післяопераційний період.

\section{Висновки}

1. Методика аденотомії у дітей з використанням електрозварювальної технології живих біологічних тканин дозволяє відновити фізіологічне дихання, значно зменшити інтраопераційну крововтрату, запобігти післяопераційній кровотечі, відновити або покращити слух та уникнути рецидиву захворювання в усіх випадках, що свідчить про високу iii ефективність.

2. Використання запропонованого пристрою для фіксації м'якого піднебіння забезпечує доступ до носоглотки під час оперативного втручання та візуальний контроль з боку ротової порожнини, допомагає запобігти травмуванню язичка під час аденотомії, а відмова від катетеризації порожнини носа виключає розвиток реактивного набряку слизової оболонки та пришвидшує відновлення носового дихання в післяопераційний період.

Автори заявляють про відсутність конфлікту інтересів.

\section{ЛITEPATУPA}

1. Безшапочный СБ, Гасюк ЮА, Смеянов ЕВ. (2017). Гиперплазия и воспаление глоточной миндалины. Київ: Логос: 123.

2. Злобина НВ, Асманов АИ, Радциг ЕЮ. (2016). Современные методы хирургического лечения структур носоглотки: преимущества и перспективы. Лечебное дело. 2: 58-63.

3. Косаківська І.А. (2012). Патент України на винахід № 99043. МПК (2012.01) А61В17/00. Біполярний електропристрій для коагуляції тканин. Заявлено 01.03.2011; Опубл. 10.07.2012 р. Бюл. №13.

4. Косаківська І.А. (2017) Патент України на корисну модель № 113320. МПК (2006.01) А61В17/24, А61В17/26. Біполярний електропристрій для коагуляції. Заявлено 02.07.2016; Опубл. 25.01.2017 р. Бюл. №2.

5. Косаківська І.А. (2017). Патент України на корисну модель № 114693. МПК (2006.01) А61В18/04, А61В18/14. Пристрій для коагуляції. Заявлено 26.10.2016; Опубл. 10.03.2017 р. Бюл. №5.

6. Косаківська І.А., Дячук В.В., Косаковський А.Л., Дячук В.В. (2011). Патент України на корисну модель № 60107. МПК (2006.01) А61B17/24. Пристрій для фіксації м'якого піднебіння. Заявлено 22.11.2010; Опубл. 10.06.2011 р. Бюл. №11.

7. Косаковський А.Л., Косаківська І.А. (2003). Деклараційний патент України на винахід № 54273 А. МПК7 А61B17/00, А61B1/ 24. Роторозширювач. Заявлено 09.07.2002; Опубл. 17.02.2003 р. Бюл. № 2 .

8. Косаковський А.Л., Косаківська І.А., Семенов Р.Г. (2010). Патент України на винахід № 91640. МПК (2009) А61B17

/32, A61B17/3205 (2006.01), А61B18/12. Аденотом А.Л. Косаковського. Заявлено 20.03.2009; Опубл. 10.08.2010 р. Бюл. №15.

9. Косаковський А.Л., Косаківська І.А., Семенов Р.Г., Семенов В.Р. (2011). Патент України на винахід № 96641. МПК А61В17/24 (2006.01), A61B17/32 (2006.01), А61B17/3211 (2006.01). Аденотом Косаковського-Семенова. Заявлено 13.01.2010; Опубл. 25.11.2011 р. Бюл. №22.

10. Косаковський А.Л., Косаківська І.А., Шух Л.А. (2003). Деклараційний патент України на винахід № 60877 А. МПК7 А61B1/24, А61B17/00. Роторозширювач. Заявлено 24.03.2003; Опубл. 15.10.2003 р. Бюл. № 10.

11. Лайко АА, Заболотний ДІ, Косаковський АЛ та ін. (2006). Аденоїдні вегетації та аденоїдити. Київ: Логос: 171.

12. Лайко АА, Заболотний ДІ, Мельников ОФ та ін. (2010). Аденоїдит. Київ: Логос: 178.

13. Лайко АА, Косаковський АЛ, Заболотна ДД та ін. (2013). Дитяча оториноларингологія. Національний підручник. За ред. Лайка АA. Київ: Логос: 576.

14. Пухлик СМ, Нейвирт ЭГ. (2002). Аденотомия: исторический аспект. Ринология. 2: 70-71.

15. Пухлик СМ. (2016). Аденотомия - исторический экскурс. Здоров'я України. 1: 37-39.

16. Bluestone D, Rosenfeld RM. (2002). Surgical atlas of Pediatric otolaryngology. London: 847.

\section{Сведения об авторах:}

Косаковская Илона Анатольевна - к.мед.н., доц. каф. детской оториноларингологии, аудиологии и фониатрии НМАПО имени П.Л. Шупика.

Адрес: г. Киев, ул. Дорогожицкая, 9; тел. (+38044) 2369448.

Статья поступила в редакцию 24.07.2018 г., принята к печати 27.11.2018 г. 


\title{
С.С. Хасанова' ${ }^{1}$ А.Т. Камилова Особенности экзокринной функции поджелудочной железы и непереносимости лактозы у недоношенных детей
}

\author{
'Республиканский перинатальный центр МЗ Республики Узбекистан, г. Ташкент \\ 2Республиканский специализированный научно-практический медицинский центр педиатрии МЗ Республики Узбекистан, г. Ташкент \\ SOVREMENNAYA PEDIATRIYA.2018.8(96):42-49; doi 10.15574/SP.2018.96.42

\begin{abstract}
В литературе имеются немногочисленные данные относительно уровней фекальной эластазы (ФЭ) у недоношенных и доношенных новорожденных, а данные о частоте лактазной недостаточности (ЛН) у новорожденных с различным сроком гестации носят противоречивый характер.

Цель - определение активности ФЭ, а также частоты встречаемости и особенностей клинических проявлений ЛН у недоношенных детей в зависимости от гестационного возраста (ГВ).

Материалы и методы. В исследование были включены 54 ребенка, рожденные в сроке от 22 до 32 недель гестации, и 8 здоровых доношенных детей (контрольная группа). Всем детям на 13-14-й день жизни, помимо общепринятого обследования, проводили анализ кала на присутствие углеводов методом Бенедикта и определение уровня ФЭ с помощью иммуноферментного анализа.

Результаты. K 14 дню жизни у детей с гестационным возрастом (ГВ) от 22 до 27 недель установлена панкреатическая недостаточность легкой степени, средние показатели ФЭ в этой группе составили 166,6士64,6 мг/г и были достоверно различны по сравнению со значениями доношенных детей, которые составили $326,0 \pm 26,0$ мг/Г $(p<0,050)$. У детей с ГВ при рождении от 28 до 32 недель к концу второй недели жизни значения панкреатической эластазы были значительно выше и составили 278,6 $\pm 10,3$ мг/г (p>0,050), и хотя они были ниже показателей у доношенных детей, разница была недостоверной ( $\mathrm{t}=1,72)$. Результаты пробы Бенедикта продемонстрировали повышение уровня предельных значений у 25 (46,3\%) обследованных детей.

Выводы. У недоношенных с ГВ 22-27 недель к двухнедельному возрасту установлена панкреатическая недостаточность легкой степени, у недоношенных детей с ГВ 28-32 недели показатели ФЭ были ниже, чем у доношенных детей, но разница была статистически незначима. Лактазная недостаточность зафиксирована у 46,3\% недоношенных детей до 32 недель, клинические проявления заболевания были неспецифичны и характеризовались разжижением стула.
\end{abstract} \\ Ключевые слова: недоношенные дети, фекальная эластаза , лактазная недостаточность.
}

\section{Features of the exocrine pancreatic function and lactose intolerance in premature babies S.S. Khasanova', A.T. Kamilova ${ }^{2}$}

${ }^{1}$ Republican Perinatal Center, Ministry of Health of the Republic of Uzbekistan, Tashkent

${ }^{2}$ Republican Specialized Scientific and Practical Medical Center of Pediatrics, Ministry of Health of the Republic of Uzbekistan, Tashkent

In the literature there are few data on the levels of fecal elastase in premature and full-term newborns, and data on the frequency of lactase deficiency (LD) in newborns with different gestational age are contradictory.

The aim of our study was to determine the activity of pancreatic elastase and lactase in premature babies up to 32 weeks. The study included 54 children born in the period from 22 to 32 weeks of gestation and 8 healthy full-term babies (control group).

Materials and methods. All children on the 13-14 $4^{\text {th }}$ day of life, in addition to the standard examination, were determined by the analysis of feces for the presence of carbohydrates by the Benedict method and determination the level of fecal elastase (FE) using enzyme immunoassay.

Results. By the 14th day of life in children with gestational age from 22 to 27 weeks, mild pancreatic insufficiency was established, the average PE in this group was $166.6 \pm 64.6 \mathrm{mg} / \mathrm{g}$ and they were significantly different compared to the full-term infants who amounted to $326.0 \pm 26.0 \mathrm{mg} / \mathrm{g}(\mathrm{p}<0.050)$, whereas in the group of children with gestational age at birth from 28 to 32 weeks by the end of the second week of life, the values of pancreatic elastase were significantly higher and amounted to $278.6 \pm 10,3 \mathrm{mg} / \mathrm{g}(\mathrm{p}>0.050)$, although they were lower than the full-term data, but the difference was not reliable ( $\mathrm{t}=1.72)$. The results of the Benedict test showed an increase in the level of limit values in $25(46.3 \%)$ children examined.

Conclusion. The data obtained allow us to conclude that mild pancreatic insufficiency was established in premature infants with a gestational age of 22-27 weeks to two weeks of age. Lactase deficiency was recorded in $46.3 \%$ of premature babies up to 32 weeks, the clinical manifestations of the disease were not specific and were characterized by stool liquefaction.

Key words: premature babies, fecal elastase, lactose insufficiency.

\section{Особливості екзокринної функції підшлункової залози і непереносимості лактози у недоношених дітей}

\section{С.С. Хасанова' ${ }^{1}$ А.Т. Камілова}

1Республіканський перинатальний центр М03 Республіки Узбекистан, м. Ташкент

Республіканський спеціалізований науково-практичний медичний центр педіатрії М03 Республіки Узбекистан, м. Ташкент

У літературі існують нечисленні дані щодо рівнів фекальної еластази (ФЕ) у недоношених і доношених новонароджених, а дані щодо частоти лактазної недостатності (ЛН) у новонароджених з різним терміном гестації суперечливі.

Мета - визначити активність панкреатичної еластази і лактази у недоношених дітей до 32 тижнів.

Матеріали і методи. У дослідження були включені 54 дитини, народжені у терміні від 22 до 32 тижнів гестації, і 8 здорових доношених дітей (контрольна група). Усім дітям на 13-14-й день життя, крім загальноприйнятого обстеження, проводили аналіз кала на наявність вуглеводів методом Бенедикта та визначення рівня ФЕ за допомогою імуноферментного аналізу.

Результати. До 14 дня життя у дітей 3 гестаційним віком (ГВ) від 22 до 27 тижнів встановлено панкреатичну недостатність легкого ступеня, середні

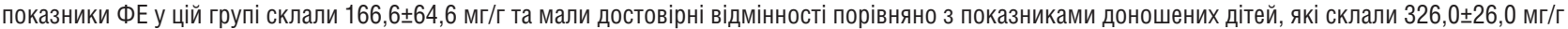
$(p<0,050)$. У дітей з ГВ при народженні від 28 до 32 тижнів до кінця другого тижня життя значення панкреатичної еластази були значно вищими та склали 278,6 $\pm 10,3$ мг/г (p>0,050), і хоча вони були нижчими від показників у доношених дітей, різниця була недостовірною (t=1,72). Результати проби Бенедикта продемонстрували підвищення рівня граничних значень у 25 (46,3\%) обстежених дітей.

Висновки. У недоношених з ГВ 22-27 тижнів до двотижневого віку встановлена панкреатична недостатність легкого ступеня, у недоношених дітей з ГВ 28-32 тижні показники ФЕ були нижчими, ніж у доношених дітей, але різниця була статистично незначна. Лактазна недостатність зафіксована у 46,3\% недоношених дітей до 32 тижнів, клінічні прояви захворювання були неспецифічними та характеризувалися розрідженням випорожнень. Ключові слова: недоношені діти, мембранне і порожнинне травлення. 


\section{Введение}

$\mathrm{H}$ едоношенные дети в раннем постнатальном онтогенезе характеризуются незрелостью многих функциональных систем, в том числе пищеварительной. Несовершенство моторно-эвакуаторной функции желудочно-кишечного тракта (ЖКТ) у них сочетается с недостаточной активностью ферментных систем, особенностями становления микробного пейзажа кишечника, что способствует развитию дисфункций пищеварения и затрудняет энтеральное вскармливание, особенно у глубоко недоношенных детей [1].

Функциональные нарушения ЖКТ довольно часто бывают проявлением перинатальных поражений ЦНС в структуре вегетативно-висцерального синдрома [5,6,11].

Основой для дисфункций пищеварения у недоношенных детей также служат расстройства полостного и пристеночного (мембранного) пищеварения, всасывания и моторики кишечника. Вместе с тем недоношенные дети крайне нуждаются в достаточном поступлении макро- и микронутриентов, чтобы сделать возможным т. н. «догоняющий рост» и обеспечить поступательное психофизическое развитие незрелого ребенка [2,3,4].

Энзимная активность обнаруживается в ткани поджелудочной железы плода до 20 недель беременности, а секреция поджелудочной железы начинается с пятого месяца, причем каждый фермент появляется и развивается индивидуально в определенный период [16,20]. Предполагается, что новорожденный выделяет значительно меньшее количество ферментов поджелудочной железы, чем дети старшего возраста или взрослые. Большинство исследований показали, что при рождении уровни протеазы близки к нормальным взрослым уровням, уровни липазы очень низкие, а уровни амилазы не обнаруживаются [11,16,18,23,38,39].

В литературе имеются немногочисленные данные относительно уровней фекальной эластазы (ФЭ) у недоношенных и доношенных новорожденных, но они носят противоречивый характер [13,24]. Вместе с тем концентрации ФЭ у недоношенных младенцев следует уделять особое внимание как раннему диагностическому признаку панкреатической недостаточности, что имеет решающее значение для раннего введения заместительной терапии ферментами поджелудочной железы с целью предотвратить развитие мальабсорбции.
Считается, что подавляющее большинство недоношенных детей имеют лактазную недостаточность (ЛН) [2], что обусловлено тем, что лактаза обнаруживается у плода уже на 10-12-й неделе гестации, с 24-й недели ее активность повышается, но при этом с 28-й до 34-й недели уровень активности составляет не более $30 \%$ такового у доношенного ребенка, который в норме превышает уровень активности у взрослого человека $[31,32]$. М.В. Heyman [14] выделяет так называемый «неонатальный дефицит развития лактазы» (developmental deficiency), характерный именно для недоношенных детей. Этот дефицит не относится к транзиторной ЛН и отмечается у всех детей, рожденных до 34-36-й недель гестации.

Данные о частоте ЛН у новорожденных с различным сроком гестации носят противоречивый характер. Исследование, выполненное D. Murray и соавт. [21] с использованием изотопного метода (изотоп углерода С13) в двух группах недоношенных детей, продемонстрировало достаточно высокую степень абсорбции у них как глюкозы, так и лактозы. При этом неясными остаются факторы, снижающие лактазную активность после рождения. В развитии ЛН авторы придают большое значение характеру микробной колонизации кишечника, особенно у детей после хирургических вмешательств (илеостомии) или получавших антибиотики.

Целью нашего исследования было определение активности ФЭ, а также частоты встречаемости и особенностей клинических проявлений ЛН у недоношенных детей в зависимости от гестационного возраста (ГВ).

\section{Материал и методы исследования}

Нами проведено проспективное исследование в отделении реанимации новорожденных и отделении выхаживания недоношенных новорожденных Республиканского перинатального центра. В исследование были включены 54 ребенка, рожденные в сроке от 22 до 32 недель гестации за период январь-март 2018 года. Всем детям помимо общепринятого обследования, включающего лабораторные анализы крови, мочи, кала, рентгенографию грудной клетки и брюшной полости, УЗИ печени, почек, головного мозга, проводили определение анализа кала на присутствие углеводов методом Бенедикта. В качестве нормы придерживались показателей углеводов в кале $0-0,05$ мг\%. 
Таблица 1

Характеристика обследованных новорожденных

\begin{tabular}{|c|c|c|c|c|}
\hline Показатель & $\begin{array}{c}1 \text { группа } \\
(n=16), M \pm m\end{array}$ & $\begin{array}{c}2 \text { группа } \\
(n=38), M \pm m\end{array}$ & $\begin{array}{l}\text { Контрольная } \\
\text { группа ( }=27)\end{array}$ & $\mathbf{p}^{*}$ \\
\hline $\begin{array}{l}\text { Гестационный возраст (нед.) } \\
\text { Колебания }\end{array}$ & $\begin{array}{l}25,9 \pm 0,4 \\
(22,4-28)\end{array}$ & $\begin{array}{c}29,9 \pm 0,1 \\
(28,3-31,5)\end{array}$ & $\begin{array}{c}38,6 \pm 0,6 \\
(37,2-39,3)\end{array}$ & $\begin{array}{l}\mathrm{p}_{1}<0,05 \\
\mathrm{p}_{2}<0,05 \\
\mathrm{p}_{3}<0,05\end{array}$ \\
\hline $\begin{array}{l}\text { Вес при рождении (г) } \\
\text { Колебания }\end{array}$ & $\begin{array}{c}974 \pm 60,3 \\
(803-1138)\end{array}$ & $\begin{array}{c}1452 \pm 58,5 \\
(820,0-2106,0)\end{array}$ & $\begin{array}{l}3262,5 \pm 188,7 \\
(2800,0-3960)\end{array}$ & $\begin{array}{l}\mathrm{p}_{1}<0,05 \\
\mathrm{p}_{2}<0,05 \\
\mathrm{p}<0,05\end{array}$ \\
\hline $\begin{array}{l}\text { Рост при рождении (см) } \\
\text { Колебания }\end{array}$ & $\begin{array}{l}32,4 \pm 0,8 \\
(27-36)\end{array}$ & $\begin{array}{l}36,5 \pm 0,3 \\
(31-40)\end{array}$ & $\begin{array}{c}50,2 \pm 0,7 \\
(47-53)\end{array}$ & $\begin{array}{l}\mathrm{p}_{1}<0,05 \\
\mathrm{p}_{2}<0,05 \\
\mathrm{p}_{3}<0,05\end{array}$ \\
\hline $\begin{array}{l}\text { Соотношение мальчиков и девочек (М/Д): } \\
\text { абс. } \\
\%\end{array}$ & $\begin{array}{c}5 / 11 \\
31,2 / 68,8 \\
\end{array}$ & $\begin{array}{c}17 / 31 \\
44,7 / 55,3\end{array}$ & $\begin{array}{c}4 / 6 \\
40 / 60\end{array}$ & $\begin{array}{l}p_{1}>0,05 \\
p_{2}>0,05 \\
p_{3}>0,05\end{array}$ \\
\hline Дородовое излитие околоплодных вод & $4(25 \%)$ & $8(21 \%)$ & $2(7,4 \%)$ & $\begin{array}{l}p_{1}<0,05 \\
p_{2}<0,05 \\
p_{3}>0,05\end{array}$ \\
\hline Длительность безводного периода (ч) & $\begin{array}{c}51,7 \pm 5,6 \\
(24-96)\end{array}$ & $\begin{array}{l}78,6 \pm 6,0 \\
(20-192)\end{array}$ & $\begin{array}{l}3,2 \pm 1,5 \\
(10-26)\end{array}$ & $\begin{array}{l}\mathrm{p}_{1}<0,05 \\
\mathrm{p}_{2}<0,05 \\
\mathrm{p}_{3}>0,05\end{array}$ \\
\hline $\begin{array}{l}\text { Не получили антенатальную стероидную просрилактику } \\
\text { или она была не завершена }\end{array}$ & $2(12,5 \%)$ & $11(29 \%)$ & 0 & $\begin{array}{l}p_{1}<0,05 \\
p_{2}<0,05 \\
p_{3}<0,05\end{array}$ \\
\hline $\begin{array}{l}\text { Оценка по Апгар } \\
\text { на 1-й мин }\end{array}$ & $5,1 \pm 0,7$ & $6,6 \pm 0,3$ & $8,2 \pm 0,3$ & $\begin{array}{l}\mathrm{p}_{1}<0,05 \\
\mathrm{p}_{2}>0,05 \\
\mathrm{p}_{3}>0,05\end{array}$ \\
\hline на 5-й мин & $6,0 \pm 0,1$ & $7,6 \pm 0,4$ & $9,1 \pm 0,2$ & $\begin{array}{l}\mathrm{p}_{1}>0,05 \\
p_{2}>0,05 \\
p_{3}>0,05\end{array}$ \\
\hline
\end{tabular}

Примечание: р1 - достоверность различий между 1 группой и здоровыми, р2 - достоверность различий между 2 группой и здоровыми, рз - достоверность различий между 1 и 2 группой.

Уровень ФЭ определяли с помощью иммуноферментного анализа (ELISA) (ScheBo-Tech, Wettenberg, Германия), при котором используются моноклональные антитела против специфических эпитопов поджелудочной железы человека. Все образцы стула хранились при температуре от $-4^{\circ} \mathrm{C}$ до $-8^{\circ} \mathrm{C}$ до анализа, [27].

Концентрацию ФЭ более 200 мг/г стула считали нормальной функцией поджелудочной железы, уровни 100-200 мг/г стула указывали на умеренную недостаточность поджелудочной железы, тяжелая экзокринная недостаточность поджелудочной железы подтверждалась уровнями ниже 100 мг/г стула [8].

Исследование на углеводы в кале и ФЭ проводилось на 13-14 день жизни, при достижении объема энтерального питания 70 и более процентов.

Исследование было выполнено в соответствии с принципами Хельсинкской Декларации. Протокол исследования был одобрен Локальным этическим комитетом (ЛЭК) всех участвующих учреждений. На проведение исследований было получено информированное согласие родителей детей (или их опекунов).
Все пациенты были разделены на две группы в зависимости от ГВ: первую группу составили дети с ГВ от 22 до 27 недель (16 детей); вторую группу составили 38 пациентов с ГВ 28-32 недели. Контрольную группу составили 27 здоровых доношенных детей (ГВ более 37 недель), средняя масса тела которых составила 3230,0 $\pm 25,0$ грамма.

Данные о ГВ, весе при рождении, поле, возрасте, росте при рождении и данные материнского анамнеза представлены в табл. 1-2.

Все дети начинали получать кормление с первых трех часов жизни, начиная со сцеживания нескольких капель молока в родильном зале, с последующим кормлением болюсно каждые три часа согласно протоколу. Кормление производилось через зонд, поскольку у 88,8\% (n=48) обследованных недоношенных сосательный рефлекс отсутствовал, а у троих был слабовыраженным. Всем новорожденным питательным субстратом являлось сцеженное грудное молоко. Наращивание объема кормления производилось согласно протоколу [7], ежедневный прирост объема составлял 10-15 мл/кг/сутки, под контролем переносимости. Все дети находились на респиратор- 
ной поддержке, при этом 74,0\% (n=40) находились на СРАР, а остальным потребовалась интубация с последующей ИВЛ (табл. 3). Разделение пациентов по нозологии представлено в табл. 4. Как видно из табл. 4, в обеих группах недоношенных детей основной нозологической единицей является синдром дыхательных расстройств (СДР). Частота НЭК во второй группе не имеет достоверных различий,а частота перфораций - несколько ниже (10,5\% против $18,7 \%)$, что, очевидно, связано с тем, что чем меньше ГВ, тем позднее сроки возникновения НЭК и такого грозного осложнения, как перфорация [25].

Исследования проводились на 14-й день жизни при достижении 70\% энтерального питания. Как видно из табл. 5, в обеих группах недоношенных преобладало искусственное вскармливание.

Математические расчеты производились с использованием пакета статистических программ StatSoft STATISTICA-6. Корреляционный анализ был проведен на основе линейного коэффициента корреляции Пирсона r.

\section{Результаты исследования}

Результаты исследования активности ФЭ продемонстрировали, что к 14 дню жизни у детей первой группы развилась панкреатическая недостаточность легкой степени, средние показатели ФЭ в этой группе составили $166,6 \pm 64,6$ мг/г и они были достоверно ниже по сравнению со значениями доношенных детей, которые составили $326,0 \pm 26,0$ мг/г $(\mathrm{p}<0,05)$, тогда как в группе детей с ГВ при рождении от 28 до 32 недель к концу второй недели жизни значения ФЭ были значительно выше и составили $278,61 \pm 10,3$ мг/г $(\mathrm{p}<0,05)$, и хотя они были ниже показателей доношенных, разница не была достоверно значимой $(\mathrm{t}-1,72)$.

Анализ частоты встречаемости легких и тяжелых форм панкреатической недостаточности у обследованных детей в зависимости от кормления и динамики прироста энтерального питания определил отчетливую взаимосвязь между степенью недоношенности и выраженностью панкреатической недостатчоности. Так, у 93,75\% новорожденных с ГВ 22-27 недель к 14 дню установлена панкреатическая недостатачность легкой степени, тогда как в группе детей с ГВ от 28 до 32 недель - только в 3 (7,91\%) случаях, а у остальных детей показатели соответствовали нормальным значениям (рис. 1).
Таблииа 2

Характеристика матерей обследованных новорожденных

\begin{tabular}{|c|c|c|c|c|}
\hline Нозология & $\begin{array}{c}1 \text { группа } \\
(n=16)\end{array}$ & $\begin{array}{c}2 \text { группа } \\
(n=38)\end{array}$ & \begin{tabular}{|c} 
Кон- \\
трольная \\
группа \\
(n=27)
\end{tabular} & $\mathbf{p}^{*}$ \\
\hline $\begin{array}{l}\text { Примение антибиоти- } \\
\text { ков во время бере- } \\
\text { менности }\end{array}$ & $\begin{array}{c}3 \\
(18,7 \%)\end{array}$ & $\begin{array}{c}10 \\
(26,3 \%)\end{array}$ & $\begin{array}{c}3 \\
(11,1 \%)\end{array}$ & $\begin{array}{l}\text { 1 } 1<0,05 \\
\text { p2<0,05 } \\
\text { p3 }>0,05\end{array}$ \\
\hline $\begin{array}{l}\text { Нарушение маточно- } \\
\text { плодово-плацентарно- } \\
\text { го кровотока II и III ст. }\end{array}$ & $\begin{array}{c}8 \\
(50 \%)\end{array}$ & $\begin{array}{c}15 \\
(39,4 \%)\end{array}$ & $\begin{array}{c}1 \\
(3,7 \%)\end{array}$ & $\begin{array}{l}\mathrm{p} 1<0,05 \\
\mathrm{p} 2<0,05 \\
\mathrm{p} 3>0,05\end{array}$ \\
\hline $\begin{array}{l}\text { Преэклампсия тяже- } \\
\text { лой степени у матери }\end{array}$ & $\begin{array}{c}4 \\
(25 \%)\end{array}$ & $\begin{array}{c}11 \\
(29 \%)\end{array}$ & $\begin{array}{c}1 \\
(10 \%)\end{array}$ & $\begin{array}{l}\text { p1<0,05 } \\
\text { p2<0,05 } \\
\text { p3 }>0,05\end{array}$ \\
\hline Оперативные роды & $\begin{array}{c}6 \\
(22,2 \%)\end{array}$ & $\begin{array}{c}17 \\
(44,7 \%)\end{array}$ & $\begin{array}{c}5 \\
(18,5 \%)\end{array}$ & $\begin{array}{l}\text { p1 } 1>0,05 \\
\text { p2<0,05 } \\
\text { p3<0,05 }\end{array}$ \\
\hline
\end{tabular}

Примечание: $\mathrm{p}_{1}$ - достоверность различий между 1 группой и здоровыми, $\mathrm{p}_{2}-$ достоверность различий между 2 группой и здоровыми, $\mathrm{p}_{3}$ - достоверность различий между 1 и 2 группой.

Характеристика респираторного статуса

Таблииа 3

\begin{tabular}{|c|c|c|c|}
\hline Показатель & $\begin{array}{c}\text { 1 группа } \\
\text { (n=16) }\end{array}$ & $\begin{array}{c}\text { 2 группа } \\
\text { (n=38) }\end{array}$ & p \\
\hline \multicolumn{4}{|c|}{ Начальное FiO2: } \\
\hline 0,21 & $35 \%$ & $57 \%$ & $>0,05$ \\
\hline $0,21-0,40$ & $53 \%$ & $27 \%$ & $<0,05$ \\
\hline $0,40-0,50$ & $6 \%$ & $11 \%$ & $<0,05$ \\
\hline $0,50-1,0$ & $6 \%$ & $5 \%$ & $>0,05$ \\
\hline \multicolumn{4}{|c|}{$\mathrm{FiO}_{2}$ К 14 дню } \\
\hline 0,21 & $41 \%$ & $85 \%$ & $<0,05$ \\
\hline $0,21-0,40$ & $20 \%$ & $11 \%$ & $<0,05$ \\
\hline $0,40-0,50$ & $26 \%$ & $2 \%$ & $<0,05$ \\
\hline $0,50-1,0$ & $13 \%$ & $2 \%$ & $<0,05$ \\
\hline Вид начальной респираторной поддержки \\
\hline $\begin{array}{c}\text { Кислород } \\
\text { свободным потоком }\end{array}$ & $26 \%$ & $2 \%$ & $<0,05$ \\
\hline СРАР & $61 \%$ & $96 \%$ & $<0,05$ \\
\hline ИВЛ & $13 \%$ & $2 \%$ & $<0,05$ \\
\hline $\begin{array}{l}\text { Потребность В ИВЛ } \\
\text { после 14 дня жизни }\end{array}$ & $31 \%$ & $39 \%$ & $>0,05$ \\
\hline
\end{tabular}

Нозологическая характеристика недоношенных детей

\begin{tabular}{|l|c|c|}
\hline \multicolumn{1}{|c|}{ Основной диагноз } & $\begin{array}{c}\text { Первая } \\
\text { группа } \\
\text { (n=16) }\end{array}$ & $\begin{array}{c}\text { Вторая } \\
\text { группа } \\
\text { (n=38) }\end{array}$ \\
\hline $\begin{array}{l}\text { Синдром дыхательных } \\
\text { расстройств (СДР) }\end{array}$ & $12(75 \%)$ & $31(81,5 \%)$ \\
\hline Врожденная пневмония/сепсис & $5(31,2 \%)$ & $5(13,1 \%)$ \\
\hline НЭК & $3(18,7 \%)$ & $6(15,7 \%)$ \\
\hline Сопутствующая патология \\
\hline Перинатальное поражение ЦНС & $10(58,8 \%)$ & $12(31,5 \%)$ \\
\hline Асфиксия & $1(6,25 \%)$ & $3(7,8 \%)$ \\
\hline
\end{tabular}

Таблии 5

Вид вскармливания на момент исследования

\begin{tabular}{|c|c|c|}
\hline Вид вскармливания & 1 группа (n=16) & 2 группа (n=38) \\
\hline Грудное & $5(31,2 \%)$ & $5(13,1 \%)$ \\
\hline Смешанное & $3(18,7 \%)$ & $10(26,3 \%)$ \\
\hline Искусственное & $8(50,1 \%)$ & $23(60,6 \%)$ \\
\hline
\end{tabular}




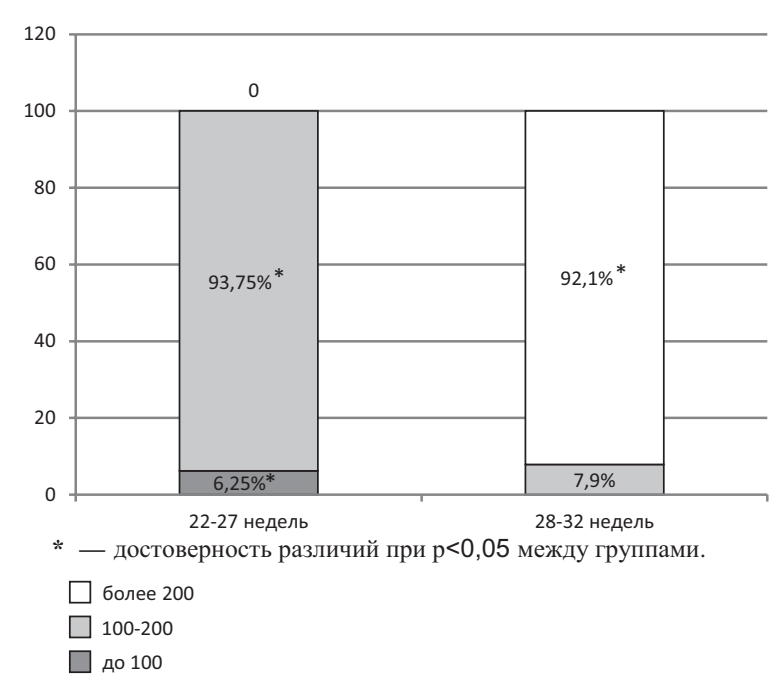

Pис. 1. Частота панкреатической недостаточности у недоношенных детей

Для определения значений ФЭ в зависимости от вида вскармливания всех недоношенных детей разделили на три группы в зависимости от степени панкреатической недостаточности и характера вскармливания. Из данных табл. 6 видна отчетливая взаимосвязь между характером кормления и активностью экскреторной функции поджелудочной железы. Наиболее благоприятная ситуация прослеживается у детей на исключительно грудном вскармливании, у которых зарегистрированы наиболее высокие значения ФЭ $(327,1 \pm 24,7)$, практически не отличающиеся от показателей доношенных новорожденных. Чуть ниже были значения ФЭ у детей на смешанном вскармливании, причем между этими двумя группами не выявлено статистически достоверной разницы. Большую часть детей составили новорожденные на искусственном вскармливании, у которых значения ФЭ были достоверно ниже, чем у детей, находящихся на грудном и смешанном вскармливании.

Мы рассмотрели возможную корреляцию между значениями ФЭ и ГВ, весом при рожде-

Зависимость уровня фекальной эластазы от характера вскармливания $(n=54)$

\begin{tabular}{|l|c|}
\hline \multicolumn{1}{|c|}{ Вскармливание } & Среднее значение ФЭ \\
\hline Грудное молоко $(\mathrm{n}=10)$ & $327,1 \pm 24,7^{*}$ \\
\hline Смешанное $(\mathrm{n}=13)$ & $313,0 \pm 16,3^{*}$ \\
\hline Искусственное $(\mathrm{n}=33)$ & $230,4 \pm 31,0$ \\
\hline $\begin{array}{l}\text { Исключительно грудное } \\
\text { (контрольная группа) }\end{array}$ & $326,2 \pm 26,0$ \\
\hline
\end{tabular}

Примечание: * - достоверность различий с детьми, находящимися на ИВ.

\begin{tabular}{|c|c|c|}
\hline \multirow[b]{2}{*}{ Показатель } & \multicolumn{2}{|c|}{$\begin{array}{c}\text { Коэффициент корреля- } \\
\text { ции Пирсона (r) }\end{array}$} \\
\hline & $\begin{array}{c}25,9 \pm 0,4 \\
(n=16) \\
(22,4-28)\end{array}$ & $\begin{array}{c}29,9 \pm 0,1 \\
(n=38) \\
(28,3-31,5)\end{array}$ \\
\hline \% прибавки веса после 7 дня жизни & - & $-0,11$ \\
\hline Скорость наращивания питания & 0,29 & 0,09 \\
\hline ВПР & 0,27 & 0,16 \\
\hline \% потери массы тела на 10 й день & 0,01 & 0,12 \\
\hline СРБ & $-0,31$ & 0,15 \\
\hline Углеводы кала & 0,15 & 0,03 \\
\hline
\end{tabular}

нии, скоростью наращивания питания, сроком, когда началась прибавка веса (табл. 7).

Определялась слабая положительная корреляция между уровнем ФЭ и скоростью наращивания питания и весом при рождении, и отрицательная корреляция слабой силы между C-реактивным белком в группе недоношенных детей с ГВ 22-27 недель. Обращает внимание зависимость активности ФЭ от скорости наращивания питания в первой группе недоношенных с низким ГВ $(\mathrm{r}=0,29)$. В группе детей с ГВ 28-32 недели значимые корреляционные взаимосвязи не установлены.

Таблица 8

Клиническая характеристика обследованных детей в зависимости от лактазной активности

\begin{tabular}{|c|c|c|c|c|c|c|}
\hline \multirow[t]{2}{*}{ Показатель } & \multicolumn{3}{|c|}{$\begin{array}{c}1 \text { группа } \\
(n=25), \text { Лн }\end{array}$} & \multicolumn{3}{|c|}{$\begin{array}{c}2 \text { группа } \\
(n=29), \text { без лн }\end{array}$} \\
\hline & $\mathbf{M}$ & & $m$ & $\mathbf{M}$ & & $m$ \\
\hline $\begin{array}{l}\text { Гестационный } \\
\text { возраст }\end{array}$ & 29,41 & \pm & 0,45 & 28,92 & \pm & 0,55 \\
\hline $\begin{array}{l}\text { Вес при } \\
\text { рождении }\end{array}$ & 1219,32 & \pm & 51,47 & 1189,92 & \pm 6 & 60,47 \\
\hline $\begin{array}{l}\text { Оценка по Апгар } \\
\text { на 1-й мин. }\end{array}$ & 7,12 & \pm & 0,24 & 7,09 & \pm & 0,14 \\
\hline $\begin{array}{l}\text { Оценка по Апгар } \\
\text { на 5-й мин. }\end{array}$ & 7,33 & \pm & 1,23 & 7,43 & \pm & 1,33 \\
\hline $\begin{array}{l}\text { Потеря массы тела } \\
\text { к } 10 \text { дню (\%) }\end{array}$ & 9,76 & \pm & 1,44 & 9,86 & \pm & 1,39 \\
\hline $\begin{array}{l}\text { День вос- } \\
\text { становления ВПР }\end{array}$ & 18,13 & \pm & 1,21 & 15,14 & \pm & 1,31 \\
\hline $\begin{array}{l}\text { Частота стула } \\
\text { на } 14 \text { й день }\end{array}$ & 7,50 & \pm & 0,20 & 7,60 & \pm & 0,30 \\
\hline $\begin{array}{l}\text { День достижения полно- } \\
\text { го энтерального питания }\end{array}$ & 17,28 & \pm & 1,53 & 16,26 & \pm & 1,44 \\
\hline Вздутие живота & \multicolumn{3}{|c|}{$13(52 \%)$} & \multicolumn{3}{|c|}{$9(31 \%)$} \\
\hline Беспокойство & \multicolumn{3}{|c|}{$8(32 \%)$} & \multicolumn{3}{|c|}{$6(29 \%)$} \\
\hline $\begin{array}{l}\text { Жидковатая } \\
\text { консистенция стула }\end{array}$ & \multicolumn{3}{|c|}{$12(48 \%)^{*}$} & \multicolumn{3}{|c|}{$6(29 \%)$} \\
\hline
\end{tabular}

Примечание: * - достоверность различий при $\mathrm{p}<0,05$. 
Результаты пробы Бенедикта продемонстрировали повышение уровня предельных значений у 25 (46,3\%) обследованных детей. Клинические проявления ЛН у недоношенных детей представлены в табл. 8. Как видно из таблицы, у недоношенных детей клиническая картина ЛН неспецифична и не имеет ярко выраженных проявлений, кроме изменения консистенции стула.

\section{Обсуждение}

Фекальная эластаза представляет собой специфическую протеазу человека, которая синтезируется ацинарной клеткой поджелудочной железы [22,28,35]. Она не деградирует во время кишечного транзита, и ее значения хорошо коррелируют с функцией поджелудочной железы [36]. Предыдущие исследования показали, что у доношенных детей, в отличие от недоношенных, уровень ФЭ к недельному возрасту достигает уровня взрослых $[13,26]$, и определили, что концентрация ФЭ у 96\% недоношенных детей к двум неделям имела более высокие значения, чем нижний предел нормальных значений взрослых, независимо от ГВ и типа питания. Однако в первые 48 часов жизни все недоношенные дети имели низкие концентрации ФЭ.

Von Seebach и Hen отмечают полезный эффект раннего энтерального питания на экзокринную функцию поджелудочной железы, что подтверждается корреляцией между увеличением ФЭ и потреблением питательных веществ [37].

Полученные нами данные по уровню ФЭ у недоношенных детей продемонстрировали зависимость ее значений от ГВ. Вместе с тем обращает внимание быстрое нарастание эластазной активности у недоношенных, родившихся в сроке 28-32 недели, по сравнению с более низким ГВ (22-27 недель).

Наши данные близки к результатам, полученным Когі и соавт. [24], которые измеряли уровень ФЭ у 77 недоношенных детей. Брали две пробы, первую - в первые 4 дня и вторую через 4-7 дней. По данным этих авторов, при сравнении уровней ФЭ во всех возрастных группах отмечалось повышение ее уровней в динамике, за исключением недоношенных, родившихся с ГВ ниже 28 недель.

Несколько иного мнения Nani Dharmasetiawani и соавт. [25], исследовавшие активность ФЭ в динамике. Ими установлено нарастание показателей эластазы с возрастом в днях, и на 14-й день недоношенные дети (авторы не уточняют ГВ) имели показатели эластазы в фекалиях 303,2 $\pm 41,0$ мг/кг, а доношенные $-312,8 \pm 48,0$ мг/кг $(\mathrm{p}>0,05)$. Примерно такие же данные получены Luigi Corvaglia и соавт. [19].

Исследования F. Campeotto и соавт. [13] обнаружили положительную корреляцию между потребляемыми калориями и уровнем эластазы в течение первой недели жизни у недоношенных детей. D.G. Burrin и соавт. [9] предлагают поддерживать стратегию «минимального энтерального питания» в качестве стратегии ускорения созревания функции ЖКТ.

Проведенные исследования показали взаимосвязь между непереносимостью питания и активностью лактазы у недоношенных новорожденных: большее потребление лактозы повышает риск к снижению толерантности питания, а вероятность ее возникновения обратно пропорциональна лактазной активности тонкой кишки [33]. Предполагается, что увеличение потребления лактозы может отрицательно влиять на увеличение веса [12].

В другом исследовании показана связь между мальабсорбцией лактозы у недоношенных новорожденных с развитием дисфункций кишечника. Так, исследования Kien [15] определило потенциальную роль мальабсорбции лактозы в развитии некротического энтероколита.

У некоторых детей мальабсорбция лактозы вызывает увеличение ферментативных продуктов (т. е. короткоцепочечных жирных кислот) и сдвига профиля короткоцепочечных жирных кислот (например, увеличение масляной кислоты), возникающих в результате бактериального метаболизма лактозы в толстой кишке [34]. Увеличение масляной кислоты было связано с гемоколитом и вздутием кишечника [34]. Было показано, что масляная кислота в высоких концентрациях токсична для слизистой оболочки толстой кишки [17]. Это было подтверждено и в экспериментальных исследованиях на модели некротизирующего энтероколита у животных, в которых показано, что появление поражений кишечника требует сочетания с низкой лактазной активностью [10].

Лактаза является единственным ферментом, ответственным за переваривание лактозы [29, 30]. Увеличение массы слизистой оболочки тонкого кишечника приводит к повышению активности фермента лактазы [31,32]. То есть прослеживается связь между снижени- 
ем массы тела и снижением активности лактазы. В наших исследованиях мы не отметили связи между ЛН и тяжестью состояния недоношенных детей.

Следует отметить, что до настоящего времени существуют нерешенные вопросы относительно применения ферментов для коррекции поджелудочной недостаточности у недоношенных детей. Это касается оптимальной дозы, кратности введения и длительности ферментной терапии. Предполагается, что экзокринная недостаточность поджелудочной железы значительно компрометирует увеличение веса у младенцев, а попытки решить эту проблему с использованием заместительной терапии поджелудочной железы не были успешными. В будущем понадобятся исследования, касающиеся заместительной терапии экзокринной недостаточности поджелудочной железы [8].

\section{Выводы}

Таким образом, нарушение полостного пищеварения, которое оценивалось нами по уровню ФЭ, более свойственно всем недоношенным детям с низким ГВ, их значения были примерно в два раза ниже, чем в контрольной группе. Полученные данные показывают, что у недоношенных с ГВ 22-27 недель к двухнедельному возрасту установлена панкреатическая недостаточность легкой степени, у недоношенных детей с ГВ 28-32 недели показатели ФЭ были ниже, чем у доношенных детей, но разница была статистически незначима.

Лактазная недостаточность зафиксирована у 46,3\% недоношенных детей до 32 недель, клинические проявления заболевания были неспецифичны и характеризовались разжижением стула.

Авторь заявляют об отсутствии конфликта интересов.

\section{ЛИТЕРАТУРА}

1. Беляева ИА, Бомбардирова ЕП, Тарзян ЭО. (2012). Дисфункции пищеварения у недоношенных детей. Вопросы современной педиатрии. 11 (6):75-79.

2. Беляева ИА, Турти ТВ, Митиш МД, Зимина ЕП, Ртищева МС, Тарзян ЭО. (2014). Профилактические аспекты вскармливания недоношенных детей грудным молоком. Педиатрическая фармакология. $11 ; 2: 13-18$

3. Диагностика и комплексная реабилитация перинатальной патологии новорожденных детей. Под. ред. проф. ГВ Яцык (2012). Москва: Педиатр.

4. Добрянский Д, Новикова О, Борисюк О, Дубровна Ю, Салабай 3. (2016). Клиническая эффективность смеси с гидролизированным белком в профилактике сниженной толерантности к энтеральному питанию у недоношенных новорожденных с очень низкой массой. Перинатология и Педиатрия. 1(65). doi: https://doi.org/10.15574/PP.2016.65.88

5. Захарова ИН, Сугян НГ. (2007). Кишечные младенческие колики и их коррекция. Педиатрия. 2: 87-90.

6. Качурина ДР, Саулебекова ЛО, Алмагамбетова АН. (2008). Особенности психоэмоционального развития и психо-соматических дисфункций у детей с перинатальным поражением центральной нервной системы. Российский вестник перинатологии и педиатрии. $51 ; 2: 41-43$

7. Протокол «Энтеральное вскармливание недоношенных». Клинические рекомендации. (2015). Москва.

8. Рылова НВ. (2018). Панкреатическая эластаза в диагностике функциональных и структурных изменений поджелудочной железы у детей. Практическая медицина. 2 (113): 66-69.

9. Burrin DG, Stoll B, Jiang R et al. (2000). Minimal enteral nutrient requirements for intestinal growth in neonatal piglets: how much is enough? Am J Clin Nutr. 71:1603-10.

10. Butel MJ, Waligora-Dupriet AJ, Szylit O. (2002). Oligofructose and experimentalmodel of neonatal necrotisingenterocolitis. $\mathrm{Br} \mathrm{J}$ Nutr. 87 (suppl):213-9.

11. Durie PR, Hamilton JR et al eds. (1996). Pediatric gastrointestinal disease. Philadelphia: Mosby:143-61.

12. Erasmus HD, Ludwig-Auser HM, Paterson PG, Sun D, Sankaran $K$. (2002). Enhanced weight gain in preterm infants receiving lactase-trea-

ted feeds: a randomized, double-blind, controlled trial. J Pediatr. 141:532-7.

13. Campeotto F, Kapel N, Kalach N, Raz H. (2002). Low levels of pancreatic elastase 1 in stools of preterm Infants. Arch Dis Child Fetal Neonatal Ed. 86: F198-F199.

14. Heyman MB. (2006). Lactose intolerance in infants, children andadolescents. Pediatrics.118:1279-1286.

15. Kien CL. (1990). Colonic fermentation of carbohydrate in the premature infant: possible relevance to necrotizing enterocolitis. $J$ Pediatr. 117: 52-8.

16. Kolack S, Puntis JWL, Lloyd DR et al. (1990). Ontogeny of pancreatic exocrinefunction. Arch Dis Child. 65:178-81.

17. Kruh J. (1982). Effects of sodium butyrate, a new pharmacological agent, oncells in culture. Mol Cell Biochem. 42:656-82.

18. Lebenthal E, Lee PC. (1980). Development of functional response in human exocrine pancreas. Pediatrics. 66:556-60.

19. Luigi Corvaglia, Vittoria Paoletti, Barbara Battistini, Patrizia Simoni, Giacomo Faldella. (2008). Lack of Correlation Between Fecal Elastase-1 Levels and Fecal Nitrogen Excretion in Preterm Infants. JPGN. 47:517-521

20. McClean P, Weaver LT. (1993). Ontogeny of human pancreatic exocrine function. Arch Dis Child. 68:62-5.

21. Murray RD, Boutton TW, Klein PD. (1990). Comparitive absorption of [13C] glucose and [13C] lactose by premature infants. Am J Clin Nutr. $51(1): 59-66$.

22. Mustafa Tahtaci, Huseyin Koseoglu, Murat Alisik, Oyku Tayfur Yurekli, Gozde Tahtaci, Ozcan Erel, Osman Ersoy. (2018). Association of Low Fecal Elastase-1 and Non-Ulcer Dyspepsia. J Clin Med. 7 (6): 155. https://doi.org/10.3390/jcm7060155

23. Kori M, Maayan-Metzger A, Shamir R, Sirota L, Dinari G. (2003). Faecalelastase 1 levels in premature and full term infants. Arch Dis Child Fetal Neonatal Ed. 88: F106-F108.

24. Nani Dharmasetiawani, Agus Firmansyah (2003). Elastase-1 concentration in feces of term and preterm infants aged $0-4$ months. Med J Indones. 12: 69-72.

25. Nino DF, Sodhi CP, Hackam DJ. (2016). Necrotizing enterocolitis: new insights into pathogenesis and mechanisms. Nat Rev Gastroenterol 
Hepatol.13(10):590-600. Epub 2016/08/18. doi 10.1038/nrgastro. 2016.119

26. Nissler K1, Von Katte I, Huebner A, Henker J (2001, Jul). Pancreaticelastase 1 in feces of pretermfants. J Pediatr Gastroenterol Nutr.33(1):28-31.

27. Pezzilli $R$ et al. (2005). The ELISA fecal elastase-1 polyclonal assay reacts with different antigens than those of the monoclonal assay. Pancreas. 31(2): 200-1.

28. Maarten R Struyvenberg, Camilia $\mathrm{R}$ Martin, Steven D. Freedman. (2017). Practical guide to exocrine pancreatic insufficiency - Breaking the myths. BMC Medicine. 15:29.

29. Ralf G Heine, Fawaz Al Refaee, Prashant Bachina, Julie C De Leon, Lanlan Geng, Sitang Gong, Jose Armando Madrazo, Jarungchit Ngamphaiboon, Christina Ong, Jossie M Rogacion Heine et al. (2017). Lactose intolerance and gastrointestinal cow's milk allergy in infants and children - common misconceptions revisited. World Allergy Organization Journal. 10:41 doi 10.1186/s40413-017-0173-0

30. Robert J Shulman, William W Wong, E O'Brian Smith. (2005). Influence of changes in lactase activity and small-intestinal mucosal growth on lactose digestion and absorption in preterm infants. Am J Clin Nutr. 81:472-9.

31. Sanderson IR. (1999). The physicochemical environment of theneonatal intestine. Am J Clin Nutr. 69 (5):1028-1034.
32. Sangild PT, Sjostrom H, Norin $\mathrm{O}$ et al. (1995). The prenatal developmentand glucocorticoid control of brush-border hydrolases in thepig small intestine. Pediatr. Res. 37 (2): 207-212.

33. Shulman RJ, Schanler RJ, Lau C, Heitkemper M, Ou C-N, Smith EO. (1998). Early feeding, feeding tolerance, and lactase activity in preterm infants. J Pediatr.133:645-9.

34. Szylit O, Maurage C, Gasqui P et al. (1998). Fecal short-chain fatty acids predictdigestive disorders in premature infants. JPEN J Parenter Enteral Nutr. 22:136-41.

35. Vanga RR, Tansel A, Sidiq S, El-Serag HB, Othman MO. (2018, Aug). Diagnostic Performance of Measurement of Fecal Elastase-1 in Detection of Exocrine Pancreatic Insufficiency: Systematic Review and Metaanalysis. Clin Gastroenterol Hepatol.16(8):1220-1228. doi 10.1016/j.cgh.2018.01.027. Epub 2018 Jan 31

36. Von Seebach I, Henker J. (1997). Pancreatic elastase 1 in faeces of preterm and term born infants up to 12 months without insufficiency of exocrine pancreatic function. Abstract from the 21st European Cystic Fibrosis Conference (EW6CF), Davos (Switzerland). June 1-6.

37. Wali PD et al. (2012). Comparison of fecal elastase- 1 and pancreatic function testing in children. J Pediatr Gastroenterol Nutr. 54(2):277-80.

38. Werlin SL. Development of the exocrine pancreas. In: Walker AW, Durie PR, Hamilton JR, et al, eds. Pediatric gastrointestinal disease. Philadelphia: Mosby, 1996:143-61.

39. Zoppi G, Andereotti G, Pajno-Ferrara F, et al. Exocrine pancreasfunction in premature and full term infants. Pediatr Res 1972. 6:880-6.

\section{Сведения об авторах:}

Хасанова Саида Сабировна - к.мед.н., зам. директора Республиканского перинатального центра РУз. Адрес: г. Ташкент, Юнус-Абадский район,

ул. Боги-Шамол, 223а; тел +998712602871

Камилова Алтиной Турсуновна - д.мед.Н., проф., руководитель отдела гастроэнтерологии и нутрициологии Республиканского специализированного научно-практического

медицинского центра педиатрии. Адрес: г. Ташкент, ул. Чимбай 2, проезд Талант,3.

Статья поступила в редакцию 11.08.2018 г., принята к печати 03.12.2018 г.

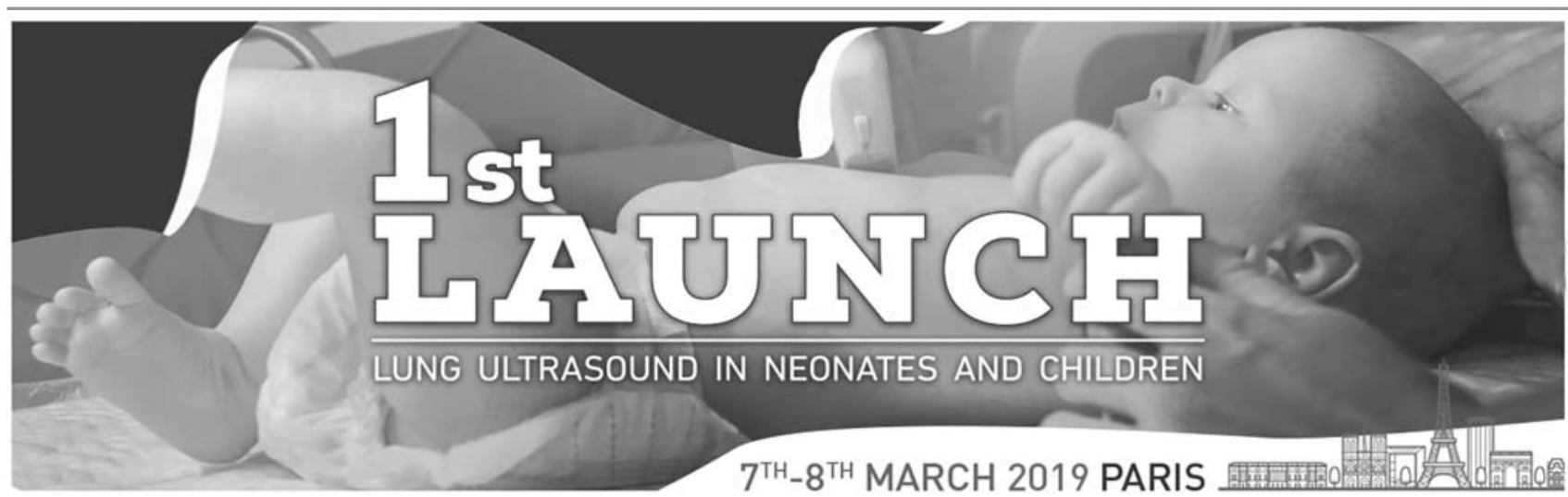

- Lung ultrasound in paediatrics and neonatology

- Point-of care ultrasound in NICU and PICU care

Abstract Submission Deadline:

January 15, 2019

5 good reasons to attend this congress

- Learn the latest achievements and discoveries in line with ultrasound

- Learn how lung ultrasound is changing NICU and PICU care

- Present your scientific work and experience in lung ultrasound for critically ill patients

- Discover how you can learn and improve your lung ultrasound skill with appropriate courses

- Meet the world's renowned critical care in lung ultrasound

More information: https://wwz.mcascientificevents.eu/firstlaunch 


\title{
І.С. Лісецька, М.М. Рожко, Р.В. Куцик \\ Антилізоцимна активність симбіонтів ясен у процесі комплексного лікування генералізованого катарального гінгівіту у підлітків з хронічним гастродуоденітом
}

\author{
ДВНЗ «Івано-Франківський національний медичний університет», Україна \\ SOVREMENNAYA PEDIATRIYA.2018.8(96):50-54; doi 10.15574/SP.2018.96.50 \\ Здатність патогенних та умовно-патогенних бактерій до тривалого виживання у ворожому середовищі господаря-макроорганізма забезпечується \\ їх персистенцією. Одним із факторів персистенції є антилізоцимна активність (АЛА), що забезпечує їм селективні переваги росту і розмноження \\ на слизових оболонках, сприяє тривалому перебуванню бактерій у макроорганізмі. Тому перспективним підходом до лікування захворювань \\ пародонта є застосування лікарських препаратів, здатних пригнічувати експресію цього фрактора персистенції патогенів або елімінувати \\ мікроорганізми з антилізоцимною активністю із складу оральних мікробіоценозів. \\ Мета - визначення антилізоцимної активності мікроорганізмів до та після комплексного лікування катарального гінгівіту у підлітків 3 хронічним \\ гастродуоденітом (ХГД). \\ Матеріали і методи. Вивчали зміни мікробіоценозу ясен 38 підлітків віком 12-18 років з генералізованим катаральним гінгівітом (ГКГ) та ХГД до та \\ після лікування, що склали основну групу. Групу порівняння склали 25 підлітків аналогічного віку 3 діагностованим ГКГ які на момент обстеження \\ не мали скарг на порушення соматичного здоров'я і не перебували на диспансерному обліку в суміжних спеціалістів. Моніторинг змін мікробіоценозу \\ ясен та АЛА проводився до лікування, після лікування та через шість місяців. \\ Результати та висновки. У підлітків з ГКГ (як на тлі супутнього ХГД, так і у соматично здорових) спостерігається різко підвищена частота колонізації \\ слизової оболонки ясен бактеріями з високою АЛА. Розроблений терапевтичний комплекс із включенням лактовмісних пробіотиків проявляє стійкий \\ коригуючий вплив на якісні характеристики мікробіоценозу ясен підлітків з ГКГ, забезпечуючи зниження персистентного потенціалу мікрофрлори \\ за рахунок зменшення здатності інактивувати лізоцим ротової рідини. \\ Ключові слова: катаральний гінгівіт, хронічний гастродуоденіт, підлітки, мікробіоценоз, антилізоцимна активність, комплексне лікування.
}

\begin{abstract}
Antilysocyme activity of the symbionts of the gums in the process of complex treatment generalizovannoe catarrhal gingivitis in adolescents with chronic gastroduodenitis I.S. Lisetska, M.M. Rozhko, R.V. Kutsyk

Ivano-Frankivsk National Medical University, Ukraine

Resume. The ability of pathogenic and conditionally pathogenic bacteria to prolong the survival in hostile host-macroorganism environments with their persistence. One of the factors of persistence is antilysosytic activity (ALA), which provides them with selective benefits of growth and reproduction on the mucous membranes, promotes prolonged stay of bacteria in the macroorganism. Therefore, the promising approach to the treatment of periodontal diseases is the use of drugs that can suppress the expression of this factor of the persistence of pathogens or eliminate microorganisms with antilisositum activity from the composition of oral microbiocenoses.

The purpose of the study was to determine one of the markers of the persistence of representatives of the microbiocenosis of periodontal tissues the antilysosytic activity of microorganisms before and after the complex treatment of catarrhal gingivitis in adolescents with chronic gastroduodenitis (HGD). Objects and methods of research: changes were studied before and after the treatment of germ microbiocenosis and ALA persistence factor in 38 adolescents with generalized catarrhal gingivitis (GKG) and HGD from 12 to 18 years old who were the main group. The group included 25 adolescents of the same age with diagnosed GKG who, at the time of the survey, did not file complaints of violations of somatic health and were not on the dispensary records of related specialists. Monitoring of changes of germs microbiocenosis and ALA was carried out before treatment, after treatment and six months later.

Results. The new therapeutic complex developed for us for the treatment of adolescents with GCG showed a pronounced corrective effect on the nature of germs microbiocenosis and proved to be well established both in the context of concomitant gastroduodenitis and in patients without concomitant gastrointestinal tract pathology. He allowed to achieve a steady reduction of the persistent potential of the gluten microflora by reducing its ability to inactivate lysozyme in the mouth fluid.

Conclusions. In adolescents with GKG (both in the background of concomitant gastroduodenitis and in somatic healthy), there is a sharp increase in the colonization rate of gum mucosa by bacteria with high ALA. The new therapeutic complex incorporating lactic probiotics has a lasting corrective effect on the qualitative characteristics of microbiocenosis gums in adolescents with GKG, providing a reduction of the persistent potential of the microflora by reducing the ability to inactivate lysozyme in the mouth fluid.

Key words: catarrhal gingivitis, chronic gastroduodenitis, adolescents, microbiocenosis, antiliosocyma activity, complex treatment.
\end{abstract}

\section{Антилизоцимная активность симбионтов десен в процессе комплексного лечения генерализованого катарального гингивита у подростков с хроническим гастродуоденитом \\ и.С. Лисецкая, Н.М. Рожко, Р.В. Куцик}

ГВУЗ «Ивано-Франковский национальный медицинский университет», Украина

Способность патогенных и условно-патогенных бактерий к длительному выживанию во враждебной среде хозяина-макроорганизма обеспечивается их персистенцией. Одним из факторов персистенции является антилизоцимная активность (АЛА), что обеспечивает им селективные преимущества роста и размножения на слизистых оболочках, способствует длительному пребыванию бактерий в макроорганизме. Поэтому перспективным подходом к лечению заболеваний пародонта является применение лекарственных препаратов, способных подавлять экспрессию этого фрактора персистенции патогенов или элиминировать микроорганизмы с антилизоцимной активностью из состава оральных микробиоценозов.

Цель - определение антилизоцимной активности микроорганизмов до и после комплексного лечения катарального гингивита у подростков с хроническим гастродуоденитом (ХГД).

Материалы и методы. Изучали изменения микробиоценоза десен у 38 подростков в возрасте 12-18 лет с генерализированным катаральным гингивитом (ГКГ) и ХГД до и после лечения, которые составили основную группу. В группу сравнения вошли 25 подростков аналогичного возраста с диагностированным ГКГ, которые на момент обследования не предъявляли жалоб на нарушения соматического здоровья и не состояли на диспансерном учете у смежных специалистов. Мониторинг изменений микробиоценоза десен и АЛА проводился до лечения, после лечения и через шесть месяцев.

Результаты и выводы. У подростков с ГКГ (как на фоне сопутствующего гастродуоденита, так и у соматически здоровых) наблюдается резко повышенная частота колонизации бактериями с высокой АЛА слизистой оболочки десен. Разработанный терапевтический комплекс с включением лактосодержащих пробиотиков проявляет устойчивое корректирующее воздействие на качественные характеристики микробиоценоза десен подростков с ГКГ, обеспечивая снижение персистентного потенциала микросрлоры за счет уменьшения способности инактивировать лизоцим ротовой жидкости.

Ключевые слова: катаральный гингивит, хронический гастродуоденит, подростки, микробиоценоз, антилизоцимная активность, комплексное лечение. 


\section{Вступ}

Ш ироке розповсюдження катарального гінгівіту серед осіб підліткового та молодого віку, відсутність вагомих успіхів його лікування у значної кількості пацієнтів, не дивлячись на успіхи в розробці нових лікарських препаратів та схем лікування, роблять дане захворювання однією 3 найбільш актуальних проблем сучасної стоматології $[5,6,9,13,15]$. У наш час бактеріальна флора ротової порожнини розглядається як первинний фактор, що викликає спочатку запальні, а згодом - запально-дистрофічні процеси в пародонтальному комплексі $[7,11,14]$. Тому останнім часом для діагностики дисбактеріозу, раціонального вибору ефективної комплексної терапії запальних захворювань пародонта привертає увагу вивчення факторів персистенції мікроорганізмів [1,4]. Наявність факторів персистенції у мікроорганізмів може сприяти тривалому розвитку захворювання. Одним із маркерів персистенції є антилізоцимна активність мікроорганізмів, яка дозволяє їм тривалий час існувати в організмі. У процесі еволюції мікроорганізми різних філогенетичних груп набули здатності синтезувати інгібітори лізоциму, що дозволяє їм виживати в біотопах організму хазяїна, зокрема у ротовій порожнині. Лізоцим $є$ важливим фактором природної резистентності організму. За рахунок мурамінідазної активності (здатності деполімеризувати пептидоглікан клітинної стінки) та катіонної природи молекули лізоцим здійснює антимікробний вплив на широкий спектр мікроорганізмів. Зменшення кількості лізоциму під впливом протеолітичних екзоферментів бактерій ротової порожнини може стати причиною, яка викликає і підтримує розвиток дисбактеріозу. Антилізоцимна активність (АЛА) мікроорганізмів є важливою біологічною властивістю, якою володіють багато видів персистентних патогенних та умовнопатогенних мікрооганизмів [2,3]. Тому перспективним підходом до лікування захворювань пародонта є застосування лікарських препаратів, здатних пригнічувати експресію цього фактора персистенції патогенів або елімінувати мікроорганізми з АЛА зі складу оральних мікробіоценозів.

Mema дослідження - визначення АЛА мікроорганізмів - одного з маркерів персистенції представників мікробіоценозу тканин пародонта - до та після комплексного лікуван- ня катарального гінгівіту у підлітків з хронічним гастродуоденітом (ХГД).

Дане дослідження є фрагментом планової НДР «Комплексна оцінка та оптимізація методів прогнозування, діагностики та лікування стоматологічних захворювань у населення різних вікових груп», № державної реєстрації 0114 U001788.

\section{Матеріал і методи дослідження}

Для досягнення поставленої мети було вивчено зміни мікробіоценозу ясен 38 до та після лікування підлітків 3 генералізованим катаральним гінгівітом (ГКГ) та ХГД віком від 12 до 18 років, що склали основну групу. Верифікацію діагнозу ХГД здійснювали лікарі відділення ендокринології та гастроентерології ОДКЛ м. Івано-Франківська на основі чинних національних та міжнародних узгоджень і рекомендацій: на підставі даних клініко-інструментального обстеження в динаміці відповідно до «Стандартів надання допомоги дітям за спеціальністю «Дитяча гастроентерологія», затверджених наказом МОЗ України від 10.08.2007 року №471, міжнародної класифікації хвороб 10-го перегляду (МКХ-10), класифікації захворювань шлунково-кишкового тракту.

До групи порівняння включили 25 підлітків аналогічного віку 3 діагностованим ГКГ, які на момент обстеження не мали скарг на порушення соматичного здоров'я і не перебували на диспансерному обліку в суміжних спеціалістів.

Діагностику катарального гінгівіту виконували відповідно до класифікації хвороб пародонта, прийнятої на XVI пленумі Всесоюзного наукового товариства стоматологів (1983). У якості контролю було проведено аналогічне дослідження у 20 підлітків відповідного віку без ознак запалення ясен та соматичних захворювань. Групи пацієнтів були однорідними за значущими показниками та репрезентативними. Розподіл пацієнтів на групи відбувався шляхом рандомізації.

Комплексну терапію ГКГ проводили згідно 3 протоколами, затвердженими наказом МО3 України №566 від 23.11.2004 р. «Про затвердження протоколів надання медичної допомоги дітям за спеціальністю дитяча терапевтична стоматологія».

Пацієнти основної групи та групи порівняння були поділені на А та Б підгрупи. Пацієнтам IA i IIA підгруп призначали застосування ком- 
бінованого рослинного протимікробного препарату, який містить суміш квіток ромашки, кори дуба, листя шавлії, трави арніки, кореневища аїру, трави м'яти перцевої, трави чебрецю звичайного у вигляді полоскань 15\% водним розчином ротової порожнини 3-4 рази на день, аплікації на слизову оболонку ясен та введення в міжзубні проміжки гелю, який містить метронідазол бензоат та хлоргексидин диглюконат 2 рази на добу. 3 метою загального лікування всередину призначали пробіотик по 1-2 капсули 3 рази на день, під час їжі.

Для місцевого медикаментозного лікування хворих ІБ і ІІБ підгруп використовували зрошення ясен $0,05 \%$ розчину хлоргексидину біглюконату, ротові ванночки настоями трав (ромашка, календула) 3-4 рази в день протягом 7 днів, аплікації на слизову оболонку ясен та введення в міжзубні проміжки мазі на основі мефенаміну натрієвої солі два рази на добу. Після нанесення мазі протягом 15 хвилин не можна полоскати рот і приймати їжу. Курс лікування становив 10 днів.

Вивчення стану мікробіоценозу проводили згідно з наказом МОЗ СРСР №535 від 22 квітня 1985 р. «Уніфікація мікробіологічних (бактеріологічних) методів дослідження, що застосовувалися у клініко-діагностичних лабораторіях лікувально-профілактичних закладів».

Забір матеріалу для бактеріологічного дослідження на предмет виявлення аеробної і факультативно-анаеробної мікрофлори із зубо-ясенної борозни робили натще, до чищення зубів, за допомогою відкаліброваної бактеріологічної петлі №1 на кров'яний агар, середовище Ендо і доставляли в мікробіологічну лабораторію протягом години. Посіви виконували за методом Голда, який дозволяє здійснити кількісну оцінку рівня мікробіологічного обсіменіння [8]. Посіви інкубували впродовж 1 доби при температурі $37^{\circ} \mathrm{C}$ в аеробних і анаеробних умовах (у герметично закритому ексикаторі) у атмосфері, збагаченій $\mathrm{CO}_{2}$.

Виділені культури ідентифікували за загальноприйнятими мікробіологічними методами відповідно до рекомендацій 9-го видання «Визначника бактерій Берджі» [12]. До уваги приймали комплекс морфологічних, культуральних та біохімічних властивостей (набори STREPTOtest 16, STAPHYtest 16, Lachema, Чехія).

Антилізоцимну активність визначали у культур, які проявили інтенсивність росту $\geq 4,0 \lg$ КУО/мл. Дослідження виконували за методом О.В. Бухаріна та співавт [2]. Навколо культур з АЛА спостерігали зони росту індикаторного штаму $M$. luteus. Кількісну оцінку АЛА кожного тест-штаму проводили за максимальною концентрацією лізоциму в чашці, яка інактивувалась даним штамом.

Мікробіологічні дослідження із визначенням АЛА виділених культур проводили до лікування, відразу після його закінчення та у віддалений термін - через 6 місяців.

Отриманий цифровий матеріал піддавали статистичному аналізу з використанням Т-критерію Стьюдента.

Дослідження виконані відповідно до принципів Гельсінської Декларації. Протокол дослідження ухвалений Локальним етичним комітетом (ЛЕК) всіх зазначених у роботі установ. Відповідно до вимог біоетики «Про проведення лабораторних досліджень біологічного матеріалу», від батьків (опікунів) кожної дитини та підлітка була отримана письмова згода на дослідження біоматеріалу.

\section{Результати дослідження та їх обговорення}

Раніше нами були описані істотні зміни кількісного та якісного складу мікробіоценозу слизової оболонки ясен у підлітків з ГКГ, які поглиблюються за наявності у пацієнтів поєднаної гастродуоденальної патології [10]. Для більш повної характеристики персистентного потенціалу симбіонтів уражених ясен у ділянці зубоясенної борозни усі мікробні культури, які проявили інтенсивність росту $\geq 4,0 \mathrm{lg}$ КУО/мл, було протестовано на АЛА. Рівень АЛА $\geq 4$ мкг/мл вважали високим.

Результати дослідження свідчать, що домінуючі у складі ясенних мікробіоценозів обстежених підлітків мікроорганізми характеризуються достатньо високим персистентним потенціалом. Це дозволяє розглядати їх у якості етіологічних чинників запалення слизової оболонки ясен. Так, культури з високою АЛА виявлені нами у $89,5 \pm 0,81 \%$ підлітків з поєднаною патологією - ГКГ на тлі супутнього ХГД. У групі пацієнтів з ГКГ без супутньої соматичної патології осіб з такою мікрофлорою було дещо менше $-80,0 \pm 1,6 \%$. Серед стоматологічно і соматично здорових підлітків мікрофлора з високою АЛА зустрічається достовірно рідше лише у 20,0 $2,11 \%$ ( $p<0,001)$.

Серед усіх протестованих учасників оральних мікробіоценозів пацієнтів з ГКГ найбільш вираженою АЛА володіють $\alpha$ - і $\beta$-гемолітичні стрептококи, дещо меншою - S. aureus і коагу- 
Антилізоцимна активність окремих учасників оральних мікробіоценозів

Таблиия у ділянці запалення слизової оболонки ясен

\begin{tabular}{|c|c|c|c|c|c|c|}
\hline \multirow[b]{2}{*}{ Мікроорганізми } & \multicolumn{3}{|c|}{ Частота АЛА (\%) } & \multicolumn{3}{|c|}{ АЛА (мКг/мЛ) } \\
\hline & $\begin{array}{c}\text { I група } \\
\text { (основна) }\end{array}$ & $\begin{array}{c}\text { II група } \\
\text { (порівняння) }\end{array}$ & $\begin{array}{l}\text { Контрольна } \\
\text { група }\end{array}$ & $\begin{array}{c}\text { I група } \\
\text { (основна) }\end{array}$ & $\begin{array}{c}\text { (I група } \\
\text { порівняння) }\end{array}$ & $\begin{array}{c}\text { Контрольна } \\
\text { група }\end{array}$ \\
\hline$\alpha$-гемолітичні Streptococcus sp. & $73,7 \pm 1,16^{\star / / 1}$ & $60,0 \pm 1,96^{*}$ & $15,0 \pm 1,79$ & $3,80 \pm 0,29^{*}$ & $3,20 \pm 0,35^{\star}$ & $1,80 \pm 1,09$ \\
\hline ק-гемолітичний Streptococcus pyogenes & $88,9 \pm 0,83^{*}$ & $75,0 \pm 1,73^{*}$ & 0 & $4,22 \pm 0,36^{* / / \pi}$ & $3,50 \pm 0,22^{*}$ & $2,00 \pm 0,03$ \\
\hline Staphylococcus aureus & $25,0 \pm 1,14^{\star / / t}$ & $100,0^{*}$ & - & $3,50 \pm 0,23^{*}$ & $4,00 \pm 0,03^{*}$ & - \\
\hline Staphylococcus epidermidis & $50,0 \pm 1,32^{\star / / 1}$ & $66,7 \pm 1,89^{*}$ & $33,3 \pm 2,36$ & $2,78 \pm 0,30^{\#}$ & $3,33 \pm 0,23^{*}$ & $2,33 \pm 0,34$ \\
\hline Stomatococcus mucilaginosus & 0 & $9,1 \pm 1,15$ & 0 & $0,86 \pm 0,13^{\star / / \#}$ & $1,41 \pm 0,32^{*}$ & $0,38 \pm 0,03$ \\
\hline Neisseria sp. & 0 & 0 & 0 & $0,55 \pm 0,06^{*}$ & $0,67 \pm 0,07^{*}$ & $0,25 \pm 0,01$ \\
\hline Micrococcus luteus & 0 & 0 & - & $0,25 \pm 0,01$ & $0,25 \pm 0,01$ & - \\
\hline Corynebacterium sp. & 0 & $3,00 \pm 0,03$ & 0 & $0,56 \pm 0,07^{*}$ & $0,38 \pm 0,03$ & $0,25 \pm 0,01$ \\
\hline E. coli & - & $100,0^{*}$ & - & - & $4,00 \pm 0,06^{*}$ & - \\
\hline Candida sp. & $66,7 \pm 1,12^{\star / / t}$ & 0 & - & $3,17 \pm 0,31^{* / / /}$ & $2,0 \pm 0,03^{*}$ & - \\
\hline
\end{tabular}

Примітка: ${ }^{*}-\mathrm{p}<0,05$ при порівнянні з контролем; ${ }^{*}-$ при порівнянні пацієнтів I та II груп.

лазонегативні стафілококи, а також дріжджоподібні гриби роду Candida (табл.). Слід зазначити, що переважна більшість культур $\alpha$-гемолітичних стрептококів, виділених від осіб контрольної групи, проявили слабку АЛА ( $\geq 1$ мкг/мл). Низькою здатністю інактивувати лізоцим характеризуються стоматококи, нейсерії, мікрококи та коринебактерії, виділені як від пацієнтів з ГКГ, так і від осіб контрольної групи.

Частоту виявлення бактерій з високою АЛА нами простежено у динаміці лікування пацієнтів з ГКГ (рис.). Пацієнти підгруп ІБ і ІІБ отримували традиційне лікування. Пацієнтам підгруп IA i IIA застосовували розроблений нами новий лікувально-профілактичний комплекс, спрямований на корекцію мікробіоценозу тканин пародонта. Поряд з протимікробними і протизапальними засобами, цей комплекс включав пробіотичний препарат лактобактерій.

Безпосередньо після закінчення курсу лікування в усіх обстежених групах пацієнтів спостерігалося істотне зменшення частки осіб 3 мікроорганізмами, які володіють високою АЛА. Найбільш виразної динаміки після проведеного лікування вдалося досягнути у пацієнтів підгруп IA, IIA і ІІБ - кількість носіїв мікрофлори з АЛА знизилася у $3,4,2,2$ і 3,0 рази відповідно $(\mathrm{p}<0,001)$. У групі ІБ цей показник також достовірно знизився, але лише у 1,6 разу $(\mathrm{p}<0,05)$, що відповідає нормальним віковим показникам у осіб контрольної групи без стоматологічної патології. Таким чином, елімінація мікроорганізмів з АЛА спостерігалася в усіх групах пацієнтів з ГКГ (як на тлі гастродуоденіту, так і без супутньої патології шлунково-кишкового тракту) незалежно від способу лікування. Тому можна припустити, що це відбувалося, передусім, за рахунок застосування адекватної протимікробної терапії.

Водночас віддалені результати лікування (через 6 місяців) при застосуванні різних терапевтичних схем істотно відрізнялися. У пацієнтів підгруп IA і IIA, лікувальний комплекс для яких включав пробіотичні лактобактерії, позитивні якісні зміни мікробіоценозу слизової оболонки ясен були стійкими. В обох підгрупах не спостерігалося достовірного збільшення частоти носіїв мікрофлори 3 АЛА. Цей показник утримувався на рівні $31,6 \pm 2,45 \%$ (підгрупа IA) i $46,2 \pm 1,92 \%$ (підгрупа IIA) порівняно з результатами відразу після лікування ( $>00,05)$. Таким чином, навіть у віддалені терміни після лікування із застосуванням лактовмісного пробіотика показник колонізації мікроорганізмами з АЛА був максимально наближеним до рівня,

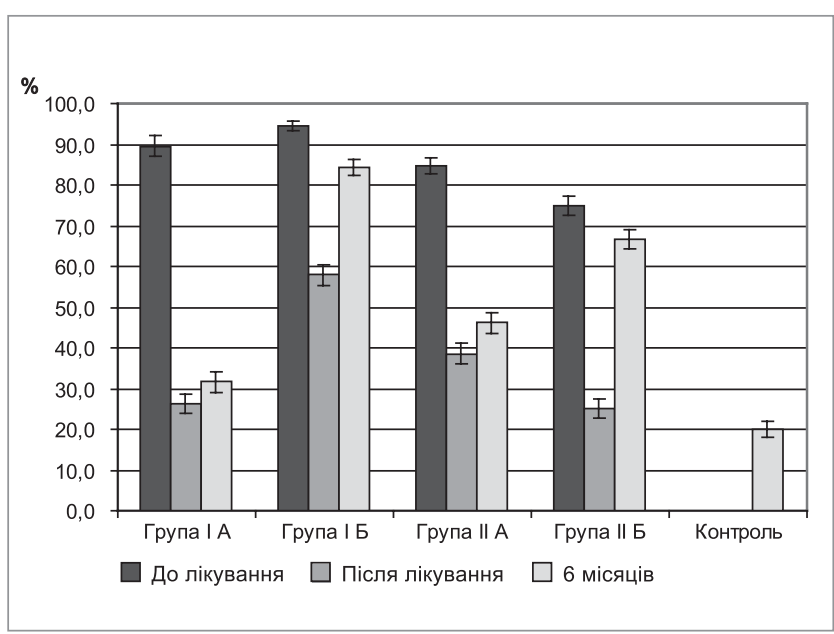

Рис. Частка пацієнтів 3 навністю у пришийковому гінгівальному мікробіоценозі бактерій з виразною АЛА ( $\geq 4$ мкг/мл при популяційному рівні $\geq 4,0 \mathrm{lg}$ КУО/мл) у процесі застосування різних лікувальних комплексів 
властивого здоровим особам відповідної вікової групи $(20,0 \pm 2,11 \%)$.

У пацієнтів підгруп ІБ і ІІБ, яким лікування ГКГ проводили традиційним способом (лише антисептиками і протизапальними засобами), у віддалені терміни спостерігалося відновлення колонізації слизової оболонки ясен бактеріями, які володіють виразною АЛА. Кількість таких пацієнтів у відповідних групах майже поверталася до початкового рівня.

Отже розроблений нами новий терапевтичний комплекс для лікування підлітків з ГКГ продемонстрував виразний коригуючий вплив на характер мікробіоценозу ясен i добре зарекомендував себе як у пацієнтів з гастродуоденітом, так і без супутньої патології шлунково-кишкового тракту. Він дозволив досягнути стійкого зниження персистентного потенціалу мікрофлори ясен за рахунок зменшення її здатності інактивувати лізоцим ротової рідини.

\section{Висновки}

1. У підлітків з ГКГ (як на тлі супутнього гастродуоденіту, так і у соматично здорових) спостерігається різко підвищена частота коло- нізації слизової оболонки ясен бактеріями з високою АЛА.

2. Новий терапевтичний комплекс із включенням лактовмісних пробіотиків чинить стійкий коригуючий вплив на якісні характеристики мікробіоценозу ясен підлітків з ГКГ, забезпечуючи зниження персистентного потенціалу мікрофлори за рахунок зменшення здатності інактивувати лізоцим ротової рідини.

Перспективи подальших досліджень. У подальших дослідженнях заплановано проведення аналізу впливу запропонованого терапевтичного комплексу на стан слизової оболонки ясен підлітків із ГКГ. Важливо буде також оцінити вплив нового лікувального підходу на окремі метаболічні властивості оральної мікрофлори, зокрема здатність ï представників до продукції пероксиду водню та нейтралізації лізоциму як одного з основних антимікробних факторів ротової рідини.

Дослідження проводилося без участі фармацевтичних компаній, а всі лікарські засоби були зареєстровані в МОЗ України в установленому порядку, призначалися звичайним способом відповідно до умов, зазначених у реєстрачійному досъє.

\section{ЛIТЕРАТУРА}

1. Буланцев АЛ, Петрова ИА, Темкин ЭС, Липницкий АВ. (2006). Обоснование исследования факторов патогенности микроорганизмов полости рта при лечении воспалительных заболеваний пародонта пробиотиками. Российский стоматологический журнал. 6:23-26.

2. Бухарин ОВ, Усвяцов БЯ, Малышкин АП, Немцева НВ. (1984). Метод определения антилизоцимной активности микроорганизмов. Журнал микробиологии, эпидемиологии и иммунобиологии. 2:27-28.

3. Бухарин ОВ, Челпаченко ОЕ, Усвяцов БЯ и др. (2003). Влияние лекарственных растений на антилизоцимную активность микроорганизмов. Антибиотики и химиотерапия. 5(48):11-14.

4. Гайрабеков PX, Гайрабекова РХ, Губханова СА, Турлова ФС, Умиева $3 Э$ (2016). Антилизоцимная, антиинтерфероновая и антикомплементарная активность некоторых бактерий семейства ENTEROBACTERIACEAE. Современные проблемы науки и образования. 5:18-24.

5. Герберт Ф Вольф, Эдит М Ратейцхак, Клаус Ратейцхак. (2014). Пародонтология. Москва: Медпресс-информ:548.

6. Дичко ЕН, Ковач IB, Хотімська ЮВ, Федоряк НВ. (2012). Частота стоматологічних захворювань у дітей. Медичні перспективи. 17;2:114-116.

7. Крисенко ОВ, Скляр ТВ, Воронкова ОС та ін. (2014). Особливості складу мікробних асоціацій та стійкості до антибіотиків мікробіоти ротової порожнини. Мікробіологія і біотехнологія. 1:35-44.

8. Лабораторные методы исследования в клинике: справочник (1987). Под ред. ВВ Меньшикова. Москва: Медицина:316-317.

9. Леус ПА, Юдина НА. (2016). Заболевание пародонта. Минск: Энергопресс:350.

10. Лісецька IC, Рожко ММ., Куцик РВ (2018). Клінічний стан та особливості мікробіоценозу тканин пародонта у підлітків із катаральним гінгівітом та хронічним гастродуоденітом. Сучасна педіатрія. 5:20-25.

11. Мащенко IC, Самойленко ВА, Пиндус ТО. (2012). Діагностична та прогностична значущість показників біоценозу та локального імунітету при хронічному генералізованому катаральному гінгівіті у юнаків. Современная стоматология.3:54-57.

12. Определитель бактерий Берджи: в 2 т. Пер. с англ. (1997). 9-е изд. Под ред. Дж Хоулта, Н Крига, П Снита, Дж Стейли, С Уильямса. Москва: Мир:553-559

13. Романенко ЕГ. (2012). Характер и частота изменений в полости рта у детей с хроническим гастродуоденитом. Здоровье ребенка. $1(36): 70-73$.

14. Савичук НО. (2015). Коррекция микроэкологических нарушений в составе лечебно-профилактических мероприятий у детей с хроническим генерализованным катаральным гингивитом. Дельта Дайджест. 1:5-8.

15. Хоменко ЛА, Дуда ОВ. (2013). Стоматологический и имунный статус детей с хроническими соматическими заболеваниями. Стоматология детского возраста и профилактика.12;4(47):57-60.

\section{Сведения об авторах:}

Лисецкая Ирина Сергеевна - ассистент каф. детской стоматологии Ивано-Франковского НМУ. Адреса: г. Ивано-Франковск, ул. Галицкая, 2.

Рожко Николай Михайлович - ректор Ивано-Франковского НМУ. Адреса: г. Ивано-Франковск, ул. Галицкая, 2.

Куцик Роман Владимирович - д.мед.н., проф., зав. каФ. микробиологии, вирусологии и иммунологии Ивано-Франковского НМУ.

Адреса: г. Ивано-Франковск, ул. Галицкая, 2.

Статья поступила в редакцию 23.07.2018 г., принята к печати 29.11.2018 г. 


\title{
Т.В. Фролова, А.Г. Амаш
}

\section{Вплив виду вигодовування на рівень цинку та фізичний розвиток дітей першого року життя}

\begin{abstract}
Харківський національний медичний університет, Україна
SOVREMENNAYA PEDIATRIYA.2018.8(96):55-60; doi 10.15574/SP.2018.96.55

Актуальним питанням сучасної педіатрії є вивчення залежності мінерального статусу дітей першого року життя та рівня фрізичного розвитку від виду вигодовування та особливостей введення прикорму, що дозволяє діагностувати елементози на етапі доклінічних проявів.

Мета: вивчення динаміки показників рівня цинку у дітей грудного віку залежно від виду вигодовування, особливостей введення прикорму та рівня фізичного розвитку.

Матеріали і методи. Обстежено 147 дітей віком від 5 місяців до 1 року, що отримували різні види вигодовування та різні продукти прикорму, введення яких відбувалося в різні терміни. Дослідження проводилося в два етапи: 1-й етап - у віці 5 місяців; 2-й - у віці 1 рік. Діти були розподілені на групи: І гр. (гр.) - 52 дитини, які знаходились на грудному вигодовуванні (ГВ) та отримували прикорм 36 місяців життя; II гр. - 17 дітей, які знаходилися на частково грудному вигодовуванні (ЧГВ) з кількістю грудного молока менш ніж 50\% за добу та отримували прикорм з 5 місяців життя; ІІІ гр. - 25 дітей, які отримували ЧГВ з більш ніж 50\% грудного молока у добовому раціоні та прикорм 36 місяців життя; IV гр. - 26 дітей, які знаходилися на штучному вигодовуванні (ШВ) та отримували прикорм з 5 місяців життя; V гр. - 24 дитини, які знаходилися на ШВ та отримували прикорм з 6 місяців життя. Визначення рівня цинку проводилось у волоссі методом спектрометрії на апараті Elvax Light (TOB «Елватех» Україна, 2008 p.). Фізичний розвиток оцінювали згідно з наказом М03 України №149 від 20.03.2008 р. та рекомендаціям В003 від 2018 р. За розрахунком середнього значення та кореляційно-регресивного аналізу в програмі Excell 2007 р. проведено статистичний аналіз отриманих результатів.

Результати. Виявлено суттєві зміни рівня цинку у дітей залежно від виду вигодовування та особливостей введення прикорму. Рівень цинку у дітей V гр. становив 8,771\%, IV гр. - 4,946\%, I гр. — 3,1\%, III гр. - 2,329\%, тоді як у дітей II гр. — 0,928\%. При обстеженні у віці одного року рівень цинку у дітей усіх груп значно збільшився і становив у дітей V гр. — 36,266\%, IV гр. — 5,295\%, I гр. — 40,524\%, III гр. — 36,532\%, а в II гр. — 5,553\% (р<0,05\% відповідно).

Висновки. У дітей першого року життя має місце взаємозв'язок між рівнем цинку, видом вигодовування, терміном введення та різноманітністю продуктів прикорму. У п'ятимісячних хлопчиків, які отримували штучні суміші, показники рівня цинку були значно вищими порівняно з дітьми, які знаходились на природному та змішаному вигодовуванні. У дітей, які отримували прикорм 36 місяців, при повторному дослідженні відмічалось значне підвищення показників вмісту цинку порівняно з дітьми, яким прикорм призначався з 5 місяців життя. При повторному дослідженні у віці одного року встановлено, що у хлопчиків, незалежно від виду вигодовування та особливостей введення прикорму, рівень цинку був вищим порівняно з його показниками у дівчаток. У дітей першого року життя не спостерігається залежності між рівнем цинку та рівнем фізичного розвитку дитини.

Ключові слова: фрізичний розвиток, вигодовування, діти, цинк, прикорм, спектрометрія волосся.
\end{abstract}

\section{Influence of a type of feeding on the zinc's level and the physical development of infants \\ T.V. Frolova, A.G. Amash \\ Kharkiv National Medical University, Ukraine}

The charcter of the infant,s diet has a significant impact on their mineral profile. It is known zinc,s levels can be changed during life: it increases physiologically in 3 month children in comparing with its birth rates and gradually decreases by the end of the first year of life. In the future, the tendency of reducing continues to a deficiency of this essential trace element in the elderly age. However, there is no data of changes of infat,s mineral profile that are depended on the level of physical development, type of feeding and characteristics or time introduction of complementary foods. All of the above determined the relevance of this research.

Aim: to study dynamics of zinc levels indicators in infants, depending on the type of feeding, the characteristics of the complementary food,s introduction and the physical development.

Materials and methods: 147 children aged from 5 months to 1 year were examined who received various types of feeding and various complementary foods, which were introduced at different times. The study was conducted in two stages: Stage 1 - at the age of 5 months; Stage 2 - at the age of 1 year. The children were divided into groups: Group I - 52 children who were breastfed and received supplements from 6 months of age; Group II 17 children who were partially breastfed with an amount of breast milk less than $50 \%$ per day and received supplements from 5 months of life; Group III — 25 children who received partial breastfeeding with more than $50 \%$ of breast milk in the daily diet and supplements from 6 months of age; Group IV — 26 children who were bottle-fed and received supplements from 5 months of age; Group V -24 children who were bottle-fed and received supplements from 6 months of age. Zinc levels were determined in the hair by spectrometry using the Elvax Light apparatus ( Elvatekh, Ukraine, 2008). Physical development was assessed according to the Order of the Ministry of Health No. 149 (20 March 2008) and the WHO recommendations (2018). According to the calculation of the average value and the correlation and regression analysis in the Excell 2007 program, a statistical analysis of the results obtained was carried out. The results of the studies indicate significant changes in the zinc level in children, depending on the type of feeding and the characteristics of the introduction of complementary foods. It was established that the level of $\mathrm{Zn}$ in children of the V group $-8.771 \%$, IV group - 4.946\%, I group - $3.1 \%$, III group $2.329 \%$, while in children of the II group - $0.928 \%$. When examined in 1 year of life, the zinc level in children of all groups increased significantly: in children of group V - 36.266\%, group IV $-5.295 \%$, group I $-40.524 \%$, group III $-36.532 \%$, and in group II $-5.553 \%$ (p <0.05\% respectively). Established a clear connection between the zinc,s indicators in children who received various types of feeding, requires further research in this direction in order to substantiate and develop predictive and preventive measures for the development of microelement homeostasis disorders of children.

Conclusions: 1 . There is a connection between the zinc,s level and the types of feeding, the period of introduction and the variety of complementary foods in infants. 2. In the five-month boys who received artificialfeeding, the indicators of zinc levels were significantly higher compared with children who were breast and mixed-fed. 3. In children, who received supplements from 6 months of life, in the repeated research, there was a significant increase in zinc levels compared to children who were given supplements from 5 months. 4 . At the second stage of the research, it was found that the boys in all types of feeding and different introductions of complementary foods had a higher level of zinc compared to its performance in girls. 5 . There is no dependence between the level of zinc and the level of physical development of the infants.

Key words: physical development; feeding; infants; zinc; complementary feeding; hair spectrometry. 


\section{Влияние вида вскармливания на уровень цинка и физическое развитие детей первого года жизни \\ Т.В. Фролова, А.Г. Амаш}

Харьковский национальный медицинский университет, Украина

Актуальным вопросом современной педиатрии является изучение зависимости минерального статуса детей первого года жизни и уровня фризического развития от вида вскармливания и особенностей введения прикорма, что позволяет диагностировать елементозы на этапе доклинических проявлений.

Цель: изучение динамики показателей уровня цинка у детей грудного возраста в зависимости от вида вскармливания, особенностей введения прикорма и уровня физического развития.

Материалы и методы. Обследовано 147 детей в возрасте от 5 месяцев до 1 года, получавших различные виды вскармливания и различные продукты прикорма, введение которых происходило в разные сроки. Исследование проводилось в два этапа: 1-й этап - в возрасте 5 месяцев; 2-й - в возрасте 1 года. Дети были разделены на группы: І гр. - 52 ребенка, которые находились на грудном вскармливании (ГВ) и получали прикорм с 6 месяцев жизни; II гр. - 17 детей, которые находились на (ЧГВ) частично грудном вскармливании с количеством грудного молока менее 50\% В сутки и получали прикорм с 5 месяцев жизни; III гр. - 25 детей, получавших ЧГВ с более чем 50\% грудного молока в суточном рационе и прикорм с 6 месяцев жизни; IV гр. - 26 детей, находившихся на искусственном вскармливании (ИВ) и получавших прикорм с 5 месяцев жизни; V гр. - 24 ребенка, которые находились на ИВ и получали прикорм с 6 месяцев жизни. Определение уровня цинка проводилось в волосах методом спектрометрии на аппарате Еlvaх Light (000 «Элватех» Украина, 2008 г.). Физическое развитие оценивали согласно Приказу МЗ Украины №149 от 20.03 .2008 г. и рекомендациям В03 от 2018 г. По расчету среднего значения и корреляционно-регрессионного анализа в программе Ехcell 2007 г. проведен статистический анализ полученных результатов. Результаты. Установлены существенные изменения уровня цинка у детей в зависимости от вида вскармливания и особенностей введения прикорма. Уровень цинка у детей V гр. составил 8,771\%, IV гр. - 4,946\%, I гр. - 3,1\%, III гр. - 2,329\%, тогда как у детей II гр. - 0,928\%. При обследовании в возрасте одного года уровень цинка у детей всех групп значительно увеличился: у детей V гр. — 36,266\%, IV гр. — 5,295\%, I гр. — 40,524\%, III гр. - 36,532\%, а во II гр. - 5,553\% ( $<<0,05 \%$ соответственно).

Выводы. У детей первого года жизни имеет место взаимосвязь между уровнем цинка, видом вскармливания, сроком ввода и разнообразием продуктов прикорма. У пятимесячных мальчиков, получавших искусственные смеси, показатели уровня цинка были значительно выше по сравнению с детьми, которые находились на естественном и смешанном вскармливании. У детей, получавших прикорм с 6 месяцев жизни, при повторном исследовании отмечалось значительное увеличение показателей содержания цинка по сравнению с детьми, которым прикорм назначался с 5 месяцев жизни. При повторном исследовании в возрасте 1 года установлено, что у мальчиков, независимо от вида вскармливания и особенностей введения прикорма, уровень цинка был выше по сравнению с его показателями у девочек. У детей первого года жизни не наблюдается зависимости между уровнем цинка и уровнем физического развития ребенка.

Ключевые слова: физическое развитие, вскармливание, дети, цинк, прикорм, спектрометрия волос.

\section{Вступ}

Грудне молоко є найбільш збалансованим 1 продуктом вигодовування дітей першого року життя. Однак, за даними ВООЗ (2018р.), у світі лише 40\% дітей віком до 6 місяців отримують грудне вигодовування. За неможливості отримувати грудне молоко 3 тих чи інших причин, дитині призначають високоадаптовані суміші. Поступово, зі збільшенням віку дитини, зростає потреба в інгредієнтах, яка компенсується введенням прикорму, що, в свою чергу, забезпечує перехід з грудного або штучного вигодовування до «дорослої» їжі та забезпечує адекватний розвиток дитячого організму. Проте ще й досі існують значні відмінності в рекомендаціях щодо вигодовування в різних країнах світу, як стосовно терміну та послідовності введення прикорму, так і вибору страв і продуктів. Згідно з наказом МО3 України №149 від 20.03.2008 р. та рекомендацій ВООЗ, прикорм пропонується вводити у віці шести місяців життя, починаючи з овочевого пюре або каш, переважно круп'яних (гречаної, рисової, кукурудзяної), з поступовим додаванням таких продуктів, як сир, м'ясне пюре, фруктове пюре тощо [4,5].

Європейська асоціація дитячої гастроентерології, гепатології та нутріціології (ESPGHAN, 2017) та Американська академія педіатрії (ААР, 2017) рекомендують введення прикорму не раніше 4-х місяців і не пізніше 6-и місяців життя, починаючи 3 продуктів, що збагачені залізом (м'ясо, риба, гречана каша), кисломолочних продуктів (йогурт, кефір, сир) та молочних каш $[9,10]$. Тоді як, згідно з рекомендаціями Австралійської асоціації клінічної імунології та алергології (ASCIA, 2017), з моменту введення першого прикорму, незважаючи на сезон року та країну мешкання, 3 метою профілактики харчової алергії діти повинні отримувати різноманітні фрукти $[7,12,14]$.

Добре відомо, що характер харчового раціону дитини першого року життя має значний вплив на їі мінеральний статус [2]. Цинк є кофактором ферментів, що беруть участь в обміні речовин і клітинному рості; підтримує імунну функцію, білковий обмін, розвиток шлунково-кишкового тракту в антенатальний та постнатальний періоди життя дитини [8]. Окрім того, він є структурним компонентом біологічних мембран, клітинних рецепторів, входить до складу понад 200 ензиматичних систем. При дефіциті цинку спостерігаються затримка росту та зниження маси тіла, а при його хронічному дефіциті відмічаються порушення у роботі печінки i/або нирок [13]. Водночас його надлишок може спричинити токсичний вплив на організм людини, особливо дитини: ураження шлунко- 
во-кишкового тракту, підвищення артеріального тиску, диспептичні прояви, уповільнення накопичення кісткової маси, запаморочення та, навіть, втрату свідомості.

Відомо, що надмірне надходження цинку аліментарним шляхом за рахунок споживання продуктів харчування неможливе [3]. Вважається, що основною причиною надмірного накопичення цинку в організмі є контакт продуктів харчування з оцинкованими предметами (каналізаційні труби, контейнери та упаковки для зберігання продуктів харчування), безконтрольне вживання препаратів і лікарських засобів для внутрішнього та зовнішнього застосування, що містять у складі цинк, а також порушення обміну самого цинку в організмі дитини [6].

Протягом життя рівень цинку коливається: у дітей після трьох місяців життя він фізіологічно підвищується у відсотковому відношенні порівняно 3 його показниками при народженні та до кінця першого року життя поступово знижується [11]. У подальшому тенденція до його зниження зберігається, призводячи до дефіциту цього есенціального мікроелемента у людей похилого віку. Проте немає даних щодо особливостей мінерального статусу дитини першого року життя залежно від рівня фізичного розвитку, виду вигодовування та урахування умов введення прикорму. Усе вищезазначене обумовило актуальність виконання даного дослідження.

Mema дослідження: вивчення динаміки показників рівня цинку у дітей грудного віку залежно від виду вигодовування, особливостей введення прикорму та рівня фізичного розвитку.

\section{Матеріал і методи дослідження}

Під спостереженням були 147 дітей віком від 5 місяців до 1 року життя, що знаходилися на різних видах вигодовування та отримували різні продукти прикорму, введення яких відбувалося в різні терміни. Дослідження проводилося у два етапи та передбачало ретельне вивчення анамнестичних даних, включаючи антенатальний та інтранатальний періоди життя, оцінку фізичного розвитку дитини до початку обстеження та протягом усього періоду проведення дослідження. 3 метою визначення мікроелементного (ME) статусу дітей проводився забір матеріалу (волосся) для проведення спектрометрії. Перший етап проводився у віці 5 місяців. У подальшому
3 різних причин (відмова батьків, невиконання умов дослідження, зміна місця проживання) $з$ дослідження були виключені 32 дитини. Друге обстеження цих дітей проводилося у віці одного року та включало контрольний огляд, антропометричні вимірювання та забір матеріалу для проведення спектрометрії. Однією 3 умов дослідження було те, що усі діти та їхні матері не отримували вітамінні та мінеральні комплекси, як до, так і протягом дослідження, і постійно проживали у м. Харкові (Україна).

На першому етапі дослідження діти були розподілені на групи за видом вигодовування та строків початку введення прикорму, які обирали з урахуванням результатів мінерального профілю дитини, а саме $\mathrm{Ca} / \mathrm{K} / \mathrm{Zn}$ співвідношення, та за об'ємом грудного молока на добу при вигодовуванні штучними сумішами.

До I групи увійшли 52 дитини (дівчаток 27, хлопчиків - 25), які знаходились на грудному вигодовуванні (ГВ) та отримували прикорм з 6 місяців життя; II групу склали 17 дітей (дівчаток - 2, хлопчиків - 15), які знаходилися на частково грудному вигодовуванні (ЧГВ) $з$ кількістю грудного молока менше ніж 50\% за добу та отримували прикорм з 5 місяців життя; до III групи увійшли 28 дітей (дівчаток - 23, хлопчиків - 5), які отримували ЧГВ з більш ніж 50\% грудного молока у добовому раціоні та прикорм з 6 місяців життя; до IV групи - 26 дітей, які знаходилися на штучному вигодовуванні (ШВ) (дівчаток - 18, хлопчиків - 8) і отримували прикорм 35 місяців життя; V групу склали 24 дитини, які знаходилися на ШВ (дівчаток15, хлопчиків - 9) і отримували прикорм з 6 місяців життя. Діти I, III та V груп у якості першої страви прикорму отримували овочеве пюре з картоплі, цвітної капусти або кабачка без додавання солі та спецій. На третьому тижні розширення меню до раціону було додано м'ясо індички чи кроля, на четвертому безмолочні каші або яблучне пюре. До 7 місяців життя діти мали в раціоні 3-4 страви, а одне годування грудьми або сумішшю було замінено на повний об'єм страви прикорму.

35 місяців життя прикорм отримували діти II та IV груп, а першим продуктом було обрано: перетерте м'ясне або рибне філе, кисломолочні продукти, пюре сезонних фруктів та овочів. На другому тижні додавалися молочні каші або суміш овочевого та м'ясного 
Таблиия 1

Середні показники рівня цинку у дітей, \%*

\begin{tabular}{|l|c|c|c|c|c|}
\hline Вік Група & I & II & III & IV & V \\
\hline 5 місяців & 3,135 & 2,329 & 0,928 & 4,946 & 8,771 \\
\hline 1 рік & 40,524 & 5,53 & 36,5 & 5,295 & 36,266 \\
\hline
\end{tabular}

Примітка: $\mathrm{p}<0,05$.

пюре. На третьому-четвертому тижні введення прикорму попередні продукти харчування комбінувалися у різних стравах. Таким чином, раціон дітей за місяць було розширено до 5-6 страв та включав продукти, які прийнято вважати облігатними алергенами. Введення різних видів прикорму проводилося за умов інформованої згоди батьків.

Визначення рівня цинку проводилось у волоссі методом спектрометрії на апараті Elvax Light (ТОВ «Елватех» Україна, 2008). Фізичний розвиток оцінювали згідно з наказом МОЗ України №149 від 20.03.2008 р. та рекомендаціями ВООЗ (2018). За розрахунком середнього значення та кореляційнорегресивного аналізу в програмі Excell 2007 р. проведено статистичний аналіз отриманих результатів.

Дослідження виконували відповідно до принципів Гельсінської декларації прав людини, Свропейської конвенції щодо захисту прав і гідності людини в аспекті біомедицини та відповідних законів України з мінімальними психологічними втратами з боку пацієнтів та з урахуванням міжнародних біоетичних стандартів про згоду батьків на участь дітей у дослідженні.

\section{Результати дослідження}

Аналіз отриманих результатів показав, що рівень цинку у дітей I групи віком 5 місяців склав $3,1 \%$ (у дівчаток - 5,700\%, у хлопчиків - 0,365\%), тоді як у дітей II групи -
0,928\% (у дівчаток - 2,990\%, у хлопчиків $0,653 \%, \mathrm{p}<0,05 \%)$. У дітей III групи рівень цинку склав 2,329\% (у дівчаток - 2,457\%, у хлопчиків - 1,739\%, p<0,05\%). У дітей IV групи рівень цинку становив 4,946\% (у дівчаток - 0,352\%, у хлопчиків - 15,281\%, $\mathrm{p}<0,05 \%)$, а у дітей $\mathrm{V}$ групи $-8,771 \%$ (у дівчаток $-0,204 \%$, у хлопчиків - 10,513\%, $\mathrm{p}<0,05 \%)$.

При контрольному обстеженні дітей у віці одного року встановлено, що рівень цинку в усіх групах значно збільшився: у дітей I групи він склав 40,524\% (у дівчаток - 40,050\%, у хлопчиків - 41,023\%), у III групі - 36,532\% (у дівчаток - 35,375\%, у хлопчиків $40,005 \%$ ), у II групі - 5,553\% (у дівчаток $5,098 \%$, у хлопчиків - 5,614\%, $<<0,05 \%)$, у IV групі - 5,295\% (у дівчаток - 5,254\%, у хлопчиків - 5,358\%, p $<0,05 \%)$, у V групі $36,266 \%$ (у дівчаток - 27,244\%, у хлопчиків $36,282 \%$, р <0,05\%) (табл. 1).

Аналіз рівня фізичного розвитку дітей показав, що 8 хлопчиків I групи, які знаходились на грудному вигодовуванні, мали надмірну вагу. Незалежно від виду вигодовування, у кожній групі спостерігалися хлопчики з вірогідністю розвитку надмірної ваги, тоді як серед дівчаток ризик розвитку надмірної ваги спостерігався лише у 11 дітей I групи. Виснаження відмічалося в одного хлопчика IV групи та у 6 хлопчиків V групи (табл. 2).

При повторному обстеженні дітей I групи у віці 1 рік із 8 хлопчиків, які мали надмірну вагу при першому дослідженні, у 4 дітей зберігались показники надмірної ваги; 4 дитини були виключені 3 подальшого дослідження у зв'язку з відмовою батьків або зміною міста мешкання. Привертає увагу тенденція до можливого розвитку надмірної ваги у 25 хлопчиків з усіх обстежених груп при першому дослідженні та іiї збереження у 22 хлопчиків при

Розподіл дітей віком 5 місяців за показниками фізичного розвитку

Таблиия 2

\begin{tabular}{|l|c|c|c|c|c|c|c|c|}
\hline \multirow{2}{*}{ Група } & \multicolumn{5}{|c|}{ Дівчатка (n=79) } & \multicolumn{4}{c|}{ Хлопчики (n=68) } \\
\cline { 2 - 9 } & $\begin{array}{c}\text { надмірна } \\
\text { вага }\end{array}$ & $\begin{array}{c}\text { можливий } \\
\text { розвиток над- } \\
\text { мірної ваги }\end{array}$ & норма & виснаження & $\begin{array}{c}\text { надмірна } \\
\text { вага }\end{array}$ & $\begin{array}{c}\text { можливий } \\
\text { розвиток } \\
\text { надмірної ваги }\end{array}$ & норма & виснаження \\
\hline I & 0 & 11 & 16 & 0 & 8 & 8 & 9 & 0 \\
\hline II & 0 & 0 & 2 & 0 & 0 & 5 & 10 & 0 \\
\hline III & 0 & 0 & 23 & 0 & 0 & 5 & 0 & 0 \\
\hline IV & 0 & 0 & 18 & 0 & 0 & 2 & 5 & 1 \\
\hline V & 0 & 0 & 9 & 0 & 0 & 5 & 4 & 6 \\
\hline
\end{tabular}


Розподіл дітей віком 1 рік за показниками фізичного розвитку

Таблиия 3

\begin{tabular}{|l|c|c|c|c|c|c|c|c|}
\hline \multirow{2}{*}{ Група } & \multicolumn{4}{|c|}{ Дівчатка $(\mathbf{n = 5 8 )}$} & \multicolumn{4}{c|}{ Хлопчики (n=57) } \\
\cline { 2 - 9 } & $\begin{array}{c}\text { надмірна } \\
\text { вага }\end{array}$ & $\begin{array}{c}\text { можливий } \\
\text { розвиток } \\
\text { надмірної ваги }\end{array}$ & норма & виснаження & $\begin{array}{c}\text { надмірна } \\
\text { вага }\end{array}$ & $\begin{array}{c}\text { можливий } \\
\text { розвиток } \\
\text { надмірної ваги }\end{array}$ & норма & виснаження \\
\hline I & 0 & 9 & 11 & 0 & 4 & 7 & 8 & 0 \\
\hline II & 0 & 0 & 2 & 0 & 0 & 5 & 10 & 0 \\
\hline III & 0 & 0 & 15 & 0 & 0 & 5 & 0 & 0 \\
\hline IV & 0 & 0 & 12 & 0 & 0 & 2 & 5 & 1 \\
\hline V & 0 & 0 & 9 & 0 & 0 & 3 & 2 & 5 \\
\hline
\end{tabular}

повторному обстеженні; 3 хлопчики були виключені з подальшого обстеження у зв'язку 3 недотриманням умов дослідження.

Також встановлено, що у 9 дівчаток I групи 3 11, що мали імовірність розвитку надмірної ваги на першому етапі дослідження, зберігається ризик розвитку надмірної ваги; 2 дівчинки були виключені з повторного етапу дослідження за бажанням батьків. У дітей, які знаходились на штучному вигодовуванні, відмічалося виснаження: 1 хлопчик з IV групи та 5 хлопчиків з V групи (табл. 3).

Встановлений чіткий взаємозв'язок між показниками цинку у дітей, які отримували різні види вигодовування, потребує проведення подальших досліджень у даному напрямку 3 метою обгрунтування та розробки прогно-

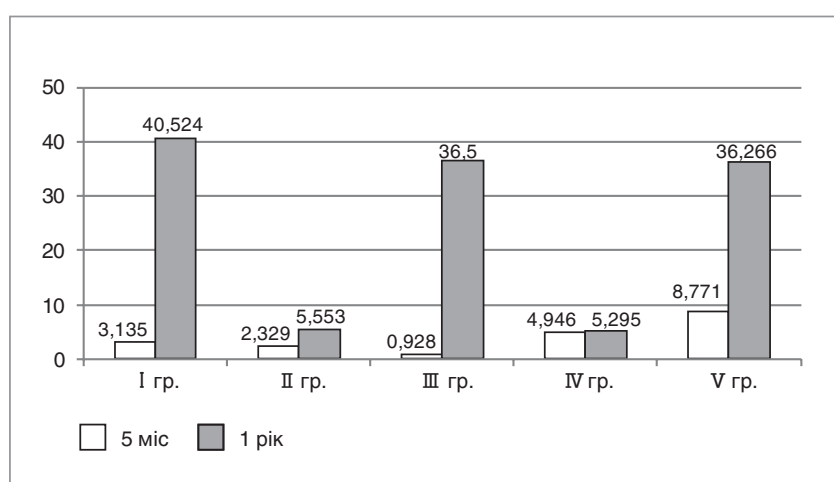

Pис. 1. Показники рівня цинку у дітей віком 5 місяців та 1 рік які отримували різні види вигодовування, залежно від терміну початку та виду прикорму (\%, p<0,05\%)

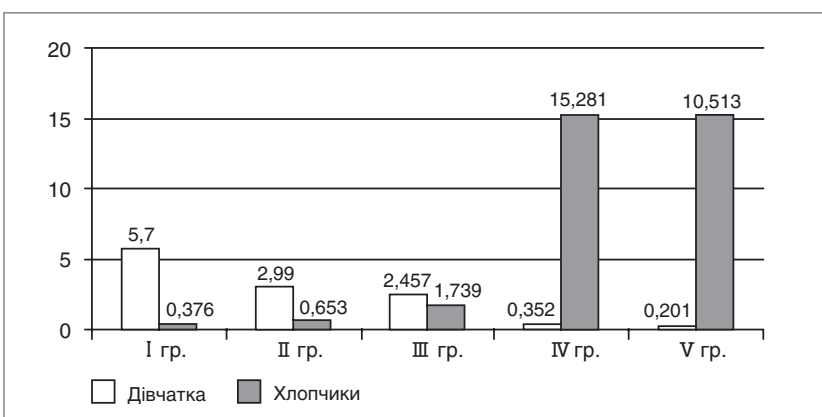

Pис. 2. Гендерні особливості рівня цинку у дітей віком 5 місяців залежно від виду вигодовування $(\% ; p<0,05)$ стично-профілактичних заходів щодо розвитку порушень мікроелементного гомеостазу у дітей раннього віку.

\section{Обговорення}

Аналіз результатів спектрометрії волосся вказує на значне збільшення рівня цинку у дітей віком 1 рік, які входили до I, III та V груп. Так, у дітей I групи показники рівня цинку при повторному дослідженні були збільшені порівняно з їх показниками у 5 місяців життя $\quad(40,524 \%$ та $3,135 \%$ відповідно, $\mathrm{p}<0,05 \%$ ). У дітей III групи, які перебували на ЧГВ та отримували більше 50\% грудного молока на добу, у віці одного року також відзначалося різке підвищення рівня цинку порівняно з їх показниками у 5 місяців (36,532\% та 2,329\% відповідно, $\mathrm{p}<0,05 \%)$. Показники рівня цинку у дітей, які знаходились на ШВ, при повторному дослідженні у віці одного року також були значно підвищеними (36,266\% та 8,771\% відповідно, р<0,05\%) (рис. 1).

Привертає увагу, що у дітей II та IV груп у віці одного року збільшення рівня цинку було невиразним порівняно 3 його показниками у 5 місяців (II гр. - 5,553\% та 2,329\% відповідно, p <0,05\%, IV гр. - 5,295\% та 4,946\% відповідно, $\mathrm{p}<0,05 \%)$.

Аналіз результатів показав, що для дітей різних груп мають місце певні гендерні відмінності щодо рівня цинку. Так, при контрольному

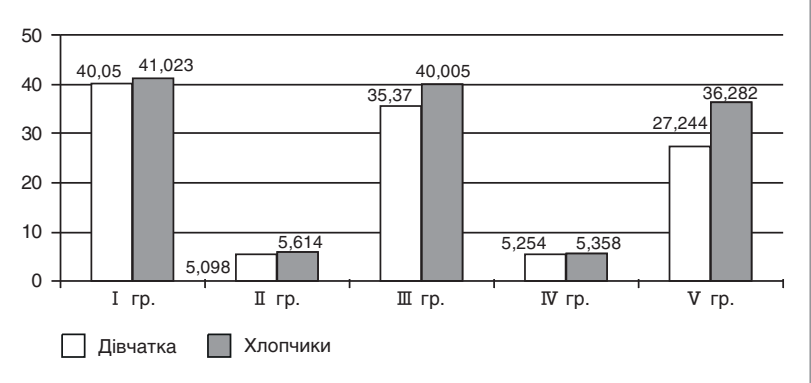

Pис. 3. Гендерні особливості рівня цинку у дітей віком один рік залежно від виду вигодовування $(\% ; p<0,05)$ 
дослідженні у дівчаток II групи рівень цинку становив $35,3 \%$, тоді як у хлопчиків - 40,005\% $(\mathrm{p}<0,05 \%) ;$ а в V групі $-27,244 \%$ у дівчаток i $36,282 \%$ у хлопчиків ( $<00,05 \%)$. За результатами спектрометрії волосся в усіх дівчаток віком 5 місяців, окрім IV та V груп, виявляється більш високий рівень цинку порівняно 3 його значеннями у хлопчиків (рис. 2).

У дітей I, II та IV груп у віці одного року достовірних гендерних відмінностей не виявлено (рис. 3).

Слід зазначити, що у віці одного року, незалежно від виду вигодовування, у хлопчиків рівень цинку вищий, ніж у дівчаток (рис. 3).

\section{Висновки}

1. У дітей першого року життя має місце взаємозв'язок між рівнем цинку, видом вигодовування, терміном введення та різноманітністю продуктів прикорму.

2. У п'ятимісячних хлопчиків, які отримували штучні суміші, показники рівня цинку були значно вищими порівняно з дітьми, які знаходились на природному та змішаному вигодовуванні.
3. У дітей, які отримували прикорм з 6 місяців, при повторному дослідженні виявлено значне підвищення показників вмісту цинку порівняно $з$ дітьми, яким прикорм призначався з 5 місяців життя.

4. При повторному дослідженні у віці одного року встановлено, що у хлопчиків, незалежно від виду вигодовування та особливостей введення прикорму, рівень цинку був вищим порівняно з показниками у дівчаток.

5. У дітей першого року життя не спостерігається залежності між рівнем цинку та рівнем фізичного розвитку дитини.

Перспектива подальших досліджень. Отримані результати дозволяють зробити висновок про необхідність планового моніторингу вмісту мікроелементів у дітей першого року життя за спектрометрією волосся, що дозволить ще на доклінічному етапі попередити формування порушень мікроелементного статусу. Перспективною є розробка прогностичної моделі щодо розвитку порушень мінерального профілю дітей $з$ урахуванням виду вигодовування та рівня фізичного розвитку дитини.

Конфлікту інтересів немає.

\section{ЛIТЕРАТУРА}

1. Охапкіна ОВ, Амаш АГ, Дубоносов ВЛ. (2016). Мінеральний профіль дітей раннього віку та його вплив на рівень фізичного розвитку. Актуальні проблеми сучасної медицини: Вісник української медичної стоматологічної академії. 16; 4-1 (56).

2. Охапкіна ОВ, Амаш АГ. (2016). Вплив виду вигодовування на макрота мікроелементний профіль дітей раннього віку. Science Rise. Medical science. 4 (3):38-42.

3. Пахомова ВГ. (2016). Вміст мікроелементів при різних формах затримки росту та шляхи корекції виявлених порушень. Дисертаційна робота на здобуття наукового ступеня кандидата наук. Київ: 186.

4. Про затвердження Клінічного протоколу медичного догляду за здоровою дитиною віком до 3 років (2008). Наказ МОЗ України №149 від 20.03.2008 p. http://www.moz.gov.ua.

5. Рекомендації ВООЗ. Питание детей грудного и раннего возраста. Інформаційний бюлетень №342 (2016, январь). www.who.int.

6. Скальный АВ. (2017). Микроэлементы: бодрость, здоровье, долголетие. Москва: Эксмо: 288

7. ASCIA Information on how to introduce solid foods to babies for allergy prevention. Parent information: Frequently asked questions (FAQ). https://www.allergy.org.au/patients/allergy-prevention/ascia-howto-introduce-solid-foods-to-babies

8. Burjonrappa SC, Miller M. (2012). Role of trace elements in parenteral nutrition support of the surgical neonate. J Pediatr Surg. 47: 760-71.

9. Di Maggio DM, Cox A, Porto AF. (2017). Updates in Infant Nutrition. Pediatrics in review. 38(10): 449. http://pedsinreview.aappublications.org/content/38/10/449

10. Fewtrell M, Bronsky J, Campoy C, Domellof M, Embleton N, Mis NF, Molgaard C. (2017). Complementary feeding: a position paper by the European Society for Paediatric Gastroenterology, Hepatology and Nutrition (ESPGHAN) Committee on Nutrition. Journal of pediatric gastroenterology and nutrition. 64(1): 119-132.

11. Ozden TA, Gokoay G, Cantez MS, Durmaz O, Issever H, Omer B, Saner G. (2015). Copper, zinc and iron levels in infants and their mothers during the first year of life: a prospective study. BMC pediatrics. 15(1): 157.

12. Pham-Thi N, Bidat E. (2014). Solid food introduction and allergic risk. Archives de pediatrie: organe officiel de la Societe francaise de pediatrie. 21(12): 1392-1395.

13. Ruktanonchai D, Lowe M, Norton SA, Garret T, Soghier L, Weiss E, Barfield W. (2014). Zinc deficiency-associated dermatitis in infants during a nationwide shortage of injectable zinc-Washington DC and Houston Texas, 2012-2013. Morbidity and Mortality Weekly Report. 63(2): 35-37.

14. Sansotta N, Piacentini GL, Mazzei F, Minniti F, Boner AL, Peroni DG. (2013). Timing of introduction of solid food and risk of allergic disease development: understanding the evidence. Allergologia et immunopathologia. 41(5): 337-345.

\section{Сведения об авторах:}

Фролова Татьяна Владимировна - д.мед.н., проф., зав. каф. пропедевтики педиатрии №1 Харьковского НМУ. Адрес: г. Харьков, пр. Науки, 4; тел.: +38(057)7252476. Амаш Анастасия Григорьевна - очный аспирант аф. пропедевтики педиатрии №1 Харьковского НМУ. Адрес: г. Харьков, пр. Науки, 4 Статья поступила в редакцию 18.07.2018 г., принята к печати 10.12.2018 г. 
Ю.П. Синяк, А.В. Купріяненко

\title{
Захворюваність на вітряну віспу населення Житомирської області (дитячого і дорослого) у 2015-2017 роках
}

\author{
КВНЗ «Житомирський медичний інститут» Житомирської обласної ради, Україна
}

\author{
SOVREMENNAYA PEDIATRIYA.2018.8(96):61-64; doi 10.15574/SP.2018.96.61
}

\begin{abstract}
Актуальність проблеми полягає в тому, що на вітряну віспу хворіють переважно діти. При даній хворобі можливий розвиток ускладнень, зумовлених як прямою дією вірусу, так і приєднанням вторинної бактеріальної інфекції.

Мета: провести аналіз рівня захворюваності на вітряну віспу дитячого і дорослого населення Житомирської області.

Матеріали і методи. Було проведено ретроспективний аналіз захворюваності на вітряну віспу населення Житомирської області за період 2015-2017 роки. У дослідженні використано клініко-статистичний метод.

Результати. Частка дитячого населення серед хворих на вітряну віспу у 2015 р. становила 70,7\%. Найчастіше хворіли діти 5-9 років, частка яких серед пацієнтів дитячого віку становила 47,3\%. у 2016 р. спостерігалося зростання захворюваності, у тому числі дитячого населення, частка якого становила 79,4\%. Найвища захворюваність спостерігалася у дітей віком 1-4 роки. Частка дорослих серед усіх хворих була найменшою у 2016 р. 20,5\% від усіх випадків. У 2017 р. спостерігалося зростання захворюваності, особливо серед дорослих. У 2017 р. найвища захворюваність серед дітей реєструвалася у віці 5-9 років.
\end{abstract}

Висновки. Вітряна віспа досить розповсюджена серед дорослого та дитячого населення Житомирської області. Найчастіше вipycom Varicella-Zoster (VZV) уражаються діти 5-9 років, тобто дошкільного віку, і в меншій мірі - шкільного.

Ключові слова: вітряна віспа, захворюваність, Житомирська область.

\section{The incidence of chickenpox of the population of Zhytomyr region (child and adult) in 2015-2017 \\ Yu.P. Sinyak, A.V. Kupryianenko \\ MHEl «Zhytomyr Medical Institute» Zhytomyr Regional Council, Ukraine}

The urgency of the problem lies in the fact that chickenpox is mainly affected by children. With this disease and possible development of complications caused by both the direct action of the virus, and the accession of a secondary bacterial infection.

Objectives: to analyze the level of morbidity in the Varicella of children and adults in Zhytomyr region.

Design and methods. To achieve the goal, the statistical method is used.

Results. In the course of the analysis of the incidence of diseases by age it was established that the share of children's population in 2015 was $70.7 \%$. Often, children aged 5-9 years were ill, the share of this age interval among the children of childhood was $47.3 \%$. In 2016, an increase in the incidence of both the general and the children's population was observed - the proportion of children accounted for $79.4 \%$ of cases. The age range with the highest incidence has changed in the direction of reduction - in 2016, the highest incidence was observed at the age of 1-4 years. The share of adults among all patients was the lowest in $2016-20.5 \%$ of all cases. In 2017 , there was an increase in the incidence in general and, especially among adults. In 2017 among children, the highest incidence was in the age range of 5-9 years.

Conclusions. The results of the study showed that chickenpox is a fairly widespread disease among the adult and infant population of Zhytomyr region. Most often, the Varicella-Zoster virus (VZV) affects children 5-9 years old, that is, preschool age, and to a lesser extent — school.

Key words: Varicella, morbidity in Zhytomyr region, adult and pediatric population.

\section{Заболеваемость ветряной оспой населения Житомирской области (детского и взрослого) в 2015-2017 годах \\ ю.Л. Синяк, А.В. Куприяненко}

КВУЗ «Житомирский медицинский институт» Житомирского областного совета, Украина

Актуальность проблемы заключается в том, что ветряной оспой болеют преимущественно дети. При данной болезни возможно развитие осложнений, обусловленных как прямым действием вируса, так и присоединением вторичной бактериальной инсрекции.

Цель: провести анализ уровня заболеваемости ветряной оспой среди детского и взрослого населения Житомирской области.

Материалы и методы. Был проведен ретроспективный анализ заболеваемости ветряной оспой населения Житомирской области за период 2015-2017 годы. В исследовании использован клинико-статистический метод.

Результаты. Доля детского населения среди больных ветряной оспой в 2015 г. составила 70,7\%. Чаще всего болели дети 5-9 лет, доля которых среди пациентов детского возраста составила 47,3\%. В 2016 г. наблюдался рост заболеваемости, в том числе детского населения, доля которого составила 79,4\%. Наибольшая заболеваемость наблюдалась у детей в возрасте 1-4 года. Доля взрослых среди всех больных была наименьшей в 2016 г. - 20,5\% от всех случаев. В 2017 г. Наблюдался рост заболеваемости, особенно среди взрослых. В 2017 г. наибольшая заболеваемость среди детей регистрировалась в возрасте 5-9 лет.

Выводы. Ветряная оспа является достаточно распространенным заболеванием среди взрослого и детского населения Житомирской области. Чаще всего вирусом Varicella-Zoster (VZV) поражаются дети 5-9 лет, то есть дошкольного возраста, и в меньшей степени - школьного. Ключевые слова: ветряная оспа, заболеваемость, Житомирская область. 


\section{Вступ}

Захворюваність дитячого населення $є$ $\mathcal{3}$ одним з найбільш важливих показників, які характеризують стан здоров'я. За даними державної статистики, на тлі зменшення чисельності дитячого населення рівні захворюваності і поширеності хвороб при спадній тенденції залишаються високими - поширеність хвороб становила 1747,7 у 2017 р. на 1000 дітей відповідного віку, а захворюваність - 1291,7 відповідно. Високою залишалась у 2017 р. захворюваність дитячого населення в Київській, Івано-Франківській, Житомирській, Дніпропетровській областях та м. Києві $[1,3]$.

Незважаючи на широке впровадження в діяльність закладів охорони здоров'я України сучасних перинатальних технологій, захворюваність дітей першого року життя впродовж 2013-2017 років також мала тенденцію до збільшення [2]. Основними причинами, на думку фахівців, є несприятливі соціальноекономічні та екологічні чинники, а також погіршення здоров'я батьків [8-11].

Структура захворюваності дитячого населення упродовж останніх років суттєво не змінилася. У 2017 р. традиційно, як і в попередні роки, на першому місці були хвороби органів дихання (їх частка становила $68,2 \%$ всіх випадків). Наступні рангові місця посіли хвороби шкіри та підшкірної клітковини (частка становила 5,1\% випадків), інфекційні і паразитарні хвороби з часткою $3,6 \%$. Серед інфекційних хвороб у дітей значна частка належить вірусним захворюванням [4-7].
Таблиия 1

Захворюваність на вітряну віспу різних категорій населення м. Житомира у 2015-2017 роках

\begin{tabular}{|l|c|c|c|c|c|c|}
\hline \multirow{2}{*}{ Категорія населення } & \multicolumn{2}{|c|}{$\mathbf{2 0 1 5}$ рік } & \multicolumn{2}{|c|}{$\mathbf{2 0 1 6}$ рік } & \multicolumn{2}{|c|}{2017 рік } \\
\cline { 2 - 8 } & абс. & \% & абс. & \% & абс. & \% \\
\hline $\begin{array}{l}\text { Усього зареєстрованих } \\
\text { випадків }\end{array}$ & 618 & 100 & 749 & 100 & 882 & 100 \\
\hline Дорослі & 181 & 29,2 & 154 & 20,5 & 200 & 22,6 \\
\hline Діти, усього & 437 & 70,7 & 595 & 79,4 & 682 & 77,3 \\
\hline 3 них 0-1 рік & 0 & 0 & 18 & 3,0 & 8 & 1,1 \\
\hline 1-4 роки & 153 & 35,0 & 292 & 49,0 & 216 & 31,6 \\
\hline 5-9 років & 207 & 47,4 & 209 & 35,1 & 312 & 45,7 \\
\hline 10-14 років & 52 & 11,9 & 55 & 9,2 & 98 & 14,3 \\
\hline 15-17 років & 25 & 5,7 & 21 & 3,5 & 48 & 7,0 \\
\hline
\end{tabular}

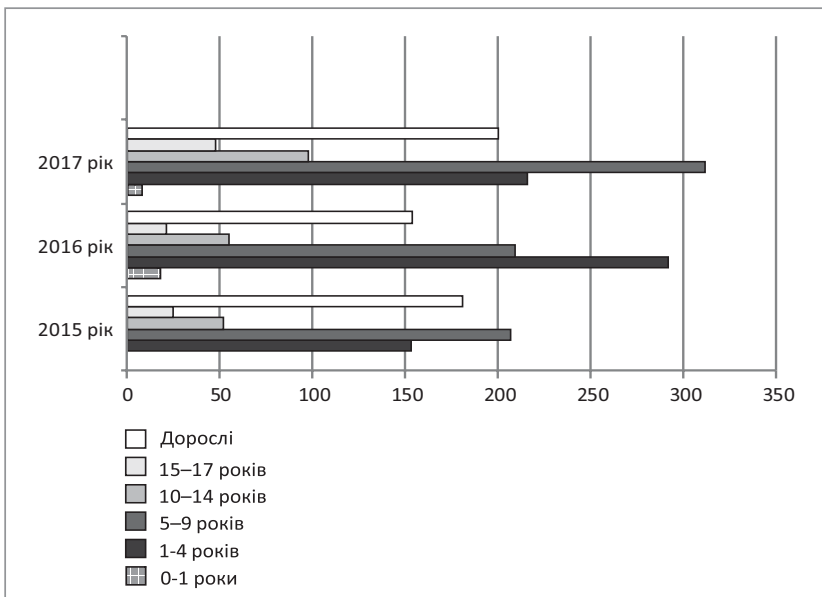

Pис. 1. Вікова структура захворюваності на вітряну віспу жителів м. Житомира

Mema дослідження - провести аналіз рівня захворюваності на вітряну віспу дитячого i дорослого населення м. Житомира та Житомирської області.

Захворюваність на вітряну віспу дитячого населення м. Житомира у 2015-2017 рр.

\begin{tabular}{|l|c|c|c|c|c|c|}
\hline \multirow{2}{*}{\multicolumn{1}{|c|}{ Показник }} & \multicolumn{2}{c|}{2015 рік } & \multicolumn{2}{c|}{2016 рік } & \multicolumn{2}{c|}{2017 рік } \\
\cline { 2 - 7 } & абс. & на 100 тис. нас. & абс. & на 100 тис. нас. & абс. & на 100 тис. нас. \\
\hline Усього випадків & 618 & 228,47 & 749 & 276,90 & 882 & 326,07 \\
\hline Серед дитячого населення & 437 & 784,91 & 595 & 1068,70 & 682 & 1224,97 \\
\hline
\end{tabular}

Аналіз захворюваності на вітряну віспу дитячого населення м. Житомира у 2015-2017 рр. за віковими категоріям

Таблиия 3

\begin{tabular}{|l|c|c|c|c|c|c|}
\hline \multirow{2}{*}{ Показник } & \multicolumn{2}{|c|}{2015} & \multicolumn{2}{c|}{$\mathbf{2 0 1 6}$} & \multicolumn{2}{c|}{2017} \\
\cline { 2 - 7 } & абс. число & на 100 тис. нас. & абс. число & на 100 тис. нас. & абс. число & на 100 тис. нас. \\
\hline Діти, усього & 437 & 784,91 & 595 & 1068,70 & 682 & 1224,97 \\
\hline 3 них: 0-1 рік & 0 & 0,0 & 18 & 474,81 & 8 & 211,03 \\
\hline $1-4$ роки & 153 & 1183,11 & 292 & 2257,96 & 216 & 1670,28 \\
\hline $5-9$ років & 207 & 1461,04 & 209 & 1475,16 & 312 & 2202,15 \\
\hline $10-14$ років & 52 & 359,04 & 55 & 379,76 & 98 & 676,66 \\
\hline $15-17$ років & 25 & 249,69 & 21 & 203,86 & 48 & 465,97 \\
\hline
\end{tabular}




\section{Матеріал і методи дослідження}

У дослідженні використано клініко-статистичний метод. Було проведено ретроспективний аналіз захворюваності на вітряну віспу населення м. Житомира та Житомирської області за період 2015-2017 роки.

\section{Результати дослідження та їх обговорення}

У табл. 1 та на рис. 1 показано рівні захворюваності на вітряну віспу жителів м. Житомира.

При проведенні аналізу захворюваності за віком встановлено, що частка дитячого населення у 2015 р. становила 70,7\%. Найчастіше хворіли діти 5-9 років, частка цього вікового інтервалу серед пацієнтів дитячого віку склала $47,3 \%$.

У 2016 р. спостерігали зростання захворюваності як загалом, так і дитячого населення зокрема - частка дітей склала $79,4 \%$ випадків. Змінився віковий інтервал з найвищою захворюваністю у бік зменшення у 2016 р. найвища захворюваність спостерігалася у віці 1-4 роки. Частка дорослих серед

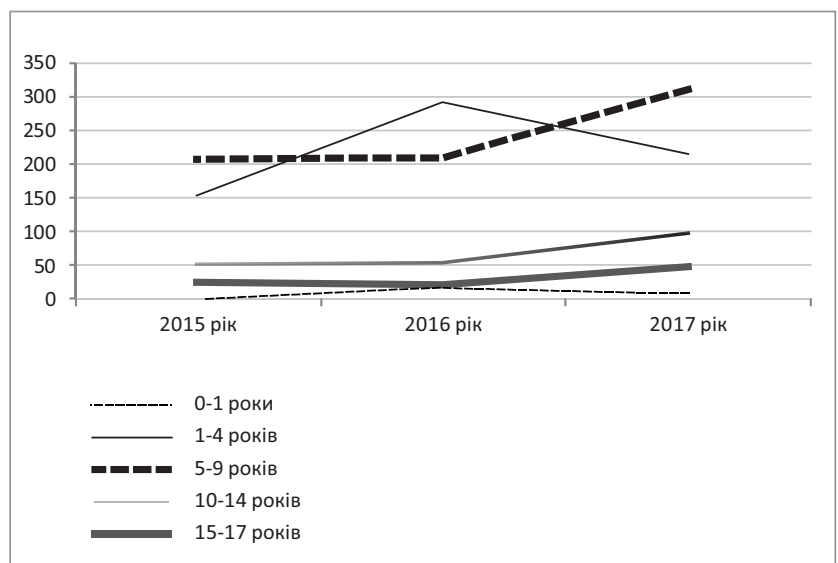

Pис. 2. Динаміка захворюваності на вітряну віспу різних вікових категорій дитячого населення м. Житомира у 2015-2017 pp.

усіх хворих була найнижчою у 2016 р. 20,5\% від усіх випадків.

У 2017 р. спостерігалося зростання захворюваності загалом, особливо серед дорослих. А серед дітей найвища захворюваність спостерігалася у віковому інтервалі 5-9 років.

Характеристика захворюваності на вітряну віспу населення

Таблиия 4 Житомирської області у 2015-2017 роках за регіонами

\begin{tabular}{|c|c|c|c|c|c|c|}
\hline \multirow{2}{*}{ Район } & \multicolumn{2}{|c|}{2015 рік } & \multicolumn{2}{|c|}{2016 рік } & \multicolumn{2}{|c|}{2017 рік } \\
\hline & абс. число & на 100 тис. & абс. число & на 100 тис. & абс. число & на 100 тис. \\
\hline Житомирська обл. & 3536 & 275,78 & 3421 & 251,18 & 4295 & 334,97 \\
\hline Андрушівський & 20 & 47,85 & 26 & 62,20 & 30 & 71,77 \\
\hline Баранівський & 110 & 255,71 & 181 & 420,75 & 459 & 1067,00 \\
\hline Бердичівський & 648 & 595,75 & 652 & 599,42 & 762 & 700,55 \\
\hline Брусилівський & 10 & 63,25 & 16 & 101,20 & 29 & 183,42 \\
\hline Ємільчинський & 97 & 276,85 & 42 & 119,87 & 131 & 373,89 \\
\hline Житомирський & 144 & 211,07 & 45 & 65,96 & 81 & 118,73 \\
\hline Коростенський & 38 & 132,59 & 33 & 115,14 & 176 & 614,10 \\
\hline Коростишівський & 140 & 340,09 & 136 & 330,37 & 145 & 352,23 \\
\hline Луганський & 51 & 292,10 & 31 & 177,55 & 32 & 183,28 \\
\hline Любарський & 72 & 259,32 & 64 & 230,51 & 22 & 79,24 \\
\hline Малинський & 37 & 78,56 & 152 & 322,72 & 100 & 212,31 \\
\hline Народицький & 6 & 66,03 & 20 & 220,09 & 16 & 176,08 \\
\hline Нов.-Волинський & 265 & 255,59 & 141 & 135,99 & 129 & 124,42 \\
\hline Пулинський & 26 & 108,87 & 12 & 50,2 & 46 & 192,62 \\
\hline Овруцький & 360 & 604,92 & 397 & 667,09 & 127 & 213,40 \\
\hline Олевський & 26 & 61,78 & 28 & 66,53 & 30 & 71,28 \\
\hline Попільнянський & 169 & 506,82 & 27 & 80,97 & 33 & 98,97 \\
\hline Радомишльський & 111 & 297,91 & 215 & 577,03 & 280 & 751,48 \\
\hline Романівський & 26 & 87,83 & 36 & 121,61 & 37 & 124,99 \\
\hline Ружинський & 46 & 157,43 & 15 & 51,33 & 21 & 71,87 \\
\hline Хорошківський & 13 & 36,47 & 13 & 36,47 & 4 & 11,22 \\
\hline Черняхівський & 24 & 77,97 & 65 & 211,18 & 94 & 305,39 \\
\hline Чуднівський & 171 & 460,11 & 90 & 242,16 & 179 & 481,64 \\
\hline м. Житомир & 618 & 228,47 & 749 & 276,90 & 882 & 326,07 \\
\hline
\end{tabular}


У табл. 2 показано захворюваність на вітряну віспу населення м. Житомира, яка зростає. Якщо у 2015 р. зареєстровано 228,47 випадку на 100 тис. населення, у 2016 р. $-276,90$ на 100 тис. населення, то у 2017 р. - вже 326,07 на 100 тис. населення.

Захворюваність дитячого населення була найменшою у 2015 році. Вона становила 784,91 випадку на 100 тис. населення, що склало 70,7\% від загальної захворюваності. У 2016 р. захворюваність на вітряну віспу дещо збільшилася і становила 1068,70 випадку на 100 тис. населення. Частка дітей у 2016 р. становила 79,4\%. Найвищою захворюваність на вітряну віспу жителів м. Житомира була у 2017 році. Вона становила 1224,97 випадку на 100 тис. населення. Частка дітей від загальної кількості хворих у 2017 р. становила 77,3\%.

Можна зробити висновок, що захворюваність на вітряну віспу зростає більш стрімко серед дорослого населення м. Житомира.

У табл. 3 надано аналіз захворюваності дитячого населення м. Житомира за віковими категоріями. Як видно з таблиці, відмічається чітка тенденція до зростання захворюваності як у дітей загалом, так i, особливо, у віці від 5 до 17 років. Так, якщо у дітей віком 10-14 років у 2015 р. захворюваність становила 359,04 на 100 тис. дитячого населення, то у 2016 р. і 2017 р. 379,76 і 676,66 на 100 тис. населення відповідно.

Спостерігається різке підвищення захворюваності серед дітей 5-9 років. У 2015 р. захворюваність склала 1461,04 на 100 тис. населення, а в 2017 р. - вже 2202,15 на 100 тис. населення, тобто захворюваність зросла у півтора разу. На рис. 2 показано динаміку захворюваності дитячого населення м. Житомира впродовж 2015-2017 pp.

У табл. 4 показано захворюваність на вітряну віспу населення Житомирщини за окремими районами. Як видно з таблиці, найвища захворюваність у 2015 р. спостерігалася серед жителів Овруцького району. Найнижчою захворюваність у 2015 р. була у жителів Хорошківського району. У 2017 р. картина захворюваності змінилася. Найвища захворюваність спостерігалася у Баранівському районі - 1067,00 на 100 тис. населення, а найнижча у Хорошківському районі. Причому рівні захворюваності між районами відрізнялися у десятки разів $(1067,0 / 11,22=95,1)$. Захворюваність у різних районах Житомирської області впродовж трьох років (2015-2017 рр. включно) змінювалася випадково.

\section{Висновки}

1. Результати дослідження показали, що вітряна віспа - досить розповсюджене захворювання, яке має тенденцію до зростання.

2. На Житомирщині за останні три роки на вітряну віспу найчастіше хворіли діти 5-9 років.

3. Найвищий рівень захворюваності серед дитячого населення м. Житомира спостерігався у 2016 році.

4. При загальній тенденції до зростання, спостерігається випадковий характер коливань захворюваності у районах області.

\section{ЛITEPATУРA}

1. Габорець ЮЮ, Дудіна ОО, Дудник СВ. (2018). Тенденції захворюваності дитячого населення України. Україна. Здоров'я нації. 3 (50): 119.

2. Про затвердження клінічних Протоколів надання медичної допомоги при невідкладних станах у дітей на шпитальному і до шпитальному етапах. Наказ МОЗ України від 31.08.2004 p. №437. http://www.moz.gov.ua.

3. Про затвердження Протоколів діагностики та лікування інфекційних хвороб у дітей. Наказ МОЗ України від 09.07.2004 р. №354. http://www.moz.gov.ua.

4. Про захист населення від інфекційних хвороб. Наказ МОЗ України від 06.04.2000 p. №1645-111. http://www.moz.gov.ua.

5. Про порядок проведення профілактичних щеплень в Україні та контроль якості й обігу медичних імунологічних препаратів. Наказ МОЗ України від 03.02.2006 p. №48 http://www.moz.gov.ua.

6. Слабкий ГО, Габорець ЮЮ, Дудіна ОО. (2018). Характеристика захворюваності дітей першого року життя. Україна. Здоров'я нації. №3 (50).

7. Davis MM, Patel MS, Gebremariam A. (2004). Decline in varicella-related hospitalizations and expenditures for children and adults after introduction of varicella vaccine in the United States // Pediatrics. 114;3: 786-792.

8. Lichenstein R. (2006, June 13). Chicken Pox or Varicella. Pediatrics. www.emedicine.com

9. Parang N Mehta (2006, July 26). Varicella. www.emedicine.com.

10. Seward JF, Watson BM, Peterson CL. (2002). Varicella disease after introduction of varicella vaccine in the United States, 1995-2000. JAMA.5:606-611.

11. Vazquez M. (2004). Varicella zoster virus infections in children after the introduction of live attenuated varicella vaccine. Curr Opin Pediatr. 16;1:80-84.

\section{Сведения об авторах:}

Синяк Юлия Павловна - магистр медсестринства, преподаватель медсестринских дисциплин КВУЗ «Житомирский медицинский институт» ЖОС.

Куприяненко Анжела Васильевна - магистр медсестринства, преподаватель медсестринских дисциплин КВУз «Житомирский медицинский институт» жОС.

Адрес: г. Житомир, ул. Большая Бердичевская, 46/15

Статья поступила в редакцию 30.07.2018 г., принята к печати 06.12.2018 г. 


\title{
Н.И. Макеева ${ }^{1,2}$, Ю.В. Одинец ${ }^{1,2}$, И.Н. Поддубная ${ }^{1,2}$ Случай анемии Фанкони у ребенка
}

\author{
${ }^{1}$ Харьковский национальный медицинский университет, Украина \\ Коммунальное некоммерческое предприятие «Городская клиническая детская больница №16» \\ Харьковского городского совета, Украина
}

SOVREMENNAYA PEDIATRIYA.2018.8(96):65-69; doi 10.15574/SP.2018.96.65

Анемия Фанкони у ребенка является редким заболеванием (его частота составляет 1:350 000), что требует проведения тщательной дифференцировки с другими формами апластической анемии. Прогноз анемии Фанкони неблагоприятный. Консервативная терапия и трансплантация костного мозга помогают в 50\% случаев. Излечения гематологического синдрома при анемии Фанкони можно добиться только с помощью аллогенной трансплантации гемопоэтических стволовых клеток.

Цель: привлечь внимание педиатров к диагностике редких гематологических синдромов.

Материалы и методы. Приведено описание клинического случая анемии Фанкони у ребенка 5 лет.

Результаты. На основании оценки анамнеза, клинического осмотра, результатов лабораторных и инструментальных методов обследования и диффференциального диагноза установлен диагноз анемии Фанкони.

Выводы. Постановка диагноза анемии Фанкони требует проведения расширенного обследования ребенка и тщательной дифференцировки с другими формами апластической анемии.

Ключевые слова: апластические анемии, анемия Фанкони, дети.

\section{Case of Fanconi anemia in a child}

N. Makieieva' ${ }^{12}$, Yu. Odinets ${ }^{12}$, I. Poddubnaya $^{12}$

${ }^{1}$ Kharkiv National Medical University, Ukraine

${ }^{2}$ Communal non-profit enterprise «Municipal Clinical Children's Hospital №16» of the Kharkiv City Council, Ukraine

Fanconi anemia in a child is a rare disease (its frequency is 1:350,000), due to it thorough differential diagnosis with other forms of aplastic anemia is necessary. The prognosis of Fanconi anemia is unfavorable. Conservative therapy and bone marrow transplantation help in $50 \%$ of cases. Allogenic transplantation of hematopoietic stem cells (THSC) is the one and only effective treatment approach.

Aim: to attract the attention of pediatricians to the diagnosis of rare hematological syndromes.

Materials and methods. Description of the clinical case of Fanconi anemia in a child of 5 years old is given.

An extended examination of the child and a thorough differential diagnosis with other forms of aplastic anemia has been performed.

Results. Based on the evaluation of history, clinical examination, laboratory and instrumental methods of examination, and differentiation with other forms of aplastic anemia the diagnosis of Fanconi anemia was made.

Conclusions. The diagnosis of Fanconi anemia requires an extended examination of the child and careful differentiation with other forms of aplastic anemia. Key words: aplastic anemia, Fanconi anemia, children.

\section{Випадок анемії Фанконі у дитини \\ Н.І. Макєєва' ${ }^{12}$ Ю.В. Одинець ${ }^{12}$, І.М. Піддубна ${ }^{12}$}

'Харківський національний медичний університет, Україна

Комунальне некомерційне підприємство «Міська клінічна дитяча лікарня №16» Харківської міської ради, Україна

Анемія Фанконі у дитини є рідкісним захворюванням (його частота становить 1:350 000), що вимагає проведення ретельного диференціювання з іншими формами апластичної анемії. Прогноз анемії Фанконі несприятливий. Консервативна терапія і трансплантація кісткового мозку допомагають у 50\% випадків. Вилікування гематологічного синдрому при анемії Фанконі можна досягти тільки за допомогою алогенної трансплантації гемопоетичних стовбурових клітин.

Мета: привернути увагу педіатрів до діагностики рідкісних гематологічних синдромів.

Матеріали і методи. Наведений опис клінічного випадку анемії Фанконі у дитини 5 років.

Результати. На підставі оцінки анамнезу, клінічного огляду та результатів лабораторних та інструментальних методів обстеження та дифреренційного діагнозу встановлено діагноз анемії Фанконі.

Висновки. Постановка діагнозу анемії Фанконі вимагає проведення розширеного обстеження дитини і ретельного диференціювання $з$ іншими формами апластичної анемії.

Ключові слова: апластична анемія, анемія Фанконі, діти.

\section{Введение}

$\mathrm{K}$ онституциональные анемии - это гетерогенная группа врожденных наследственных заболеваний, к числу которых относятся анемия Фанкони, анемия Даймонда-Блекфена, врожденный дискератоз и др. [5]. Анемия Фанкони, впервые описанная в 1927 году, является аутосомно-рецессивным заболеванием, характеризующимся прогрессирующей панцитопенией, меланодермией, эндокринными нарушениями, наличием различных врожденных аномалий и предрасполо- женностью к злокачественным заболеваниям. Частота анемии Фанкони составляет 1:350000. Мальчики поражаются чаще. Заболевание наиболее распространено среди народов Южной Африки и евреев ашкенази. В литературе описано более 1000 случаев анемии Фанкони.

Описано 15 генов, мутации в которых приводят к панцитопении. Один из них локализован на $\mathrm{X}$-хромосоме, остальные - на аутосомах (20, 22 и других). Эти гены кодируют белки, отвечающие за репарацию ДНК [6]. В 2015 году описан еще один новый подтип 
анемии Фанкони [8]. Клинические проявления анемии Фанкони возникают в возрасте 4-10 лет. Ранними признаками патологии являются беспричинные кровотечения, кровоизлияния на коже, бледность кожных покровов и слизистых оболочек, вялость, утомляемость. Дети, страдающие анемией Фанкони, подвержены частым инфекционным заболеваниям. Гепатолиенальный синдром при этом не возникает, но могут увеличиваться лимфатические узлы. Приблизительно у $2 / 3$ пациентов определяются врожденные аномалии, такие как избыточная пигментация кожи, маленький рост и размер головы, косолапость, вывих бедра, недоразвитие лучевой кости, укорочение (отсутствие) больших пальцев на руках, косоглазие, птоз век, глухота, недоразвитие глаз, умственная отсталость, гипоплазия половых органов, монорхизм, аномальное расположение внешнего отверстия мочеиспускательного канала, почечные аномалии, пороки сердца [9]. Согласно исследованиям Международного регистра анемии Фанкони, риск развития острого миелоидного лейкоза или миелодиспластического синдрома у больных анемией Фанкони равен 52\% к 40 годам [1]. Кроме того, для больных анемией Фанкони характерна склонность к развитию опухолей. Риск развития злокачественных опухолей у них составляет $10 \%$, из них $5 \%$ приходится на долю опухолей печени и 5\% - на остальные опухоли. В детском возрасте опухоли встречаются реже, средний возраст диагностики опухолей печени составляет 16 лет, а остальных опухолей 23 года. Опухоли печени (гепатоцеллюлярная карцинома, гепатома, аденома и др.), а также пелиоз («кровяные озерца») встречаются чаще у мужчин (соотношение 1,6:1), причём применение андрогенов увеличивает риск их возникновения. В то же время внепечёночные опухоли чаще встречаются у женщин (соотношение 3:1) даже после исключения опухолей гинекологической сферы. Самые частые формы рака при анемии Фанкони - чешуйчатоклеточные карциномы языка и рак пищевода, на которые приходится более $30 \%$ всех внепечёночных опухолей при анемии Фанкони, остальные опухоли встречаются в 5-7 раз реже [2]. Диагноз анемии Фанкони основывается на типичных внешних признаках, семейном анамнезе, данных клинического анализа крови и цитогенетического исследования.

В анализе крови в начале заболевания отмечается снижение количества тромбоцитов и лейкоцитов, при прогрессировании заболевания - панцитопения, повышение фетального гемоглобина. При цитогенетическом исследовании выявляются специфические хромосомные аномалии. Число хромосом не изменяется [3].

Костный мозг обеднен кроветворными клеточными элементами, преобладают лимфоциты, встречаются плазматические, тучные клетки и стромальные элементы - клиническая картина не отличима от идиопатической апластической анемии. Зачастую в аспирате костного мозга обнаруживают дисмиелопоэз и дизэритропоэз, в частности, мегалобластоидность, из-за которой Фанкони назвал эту анемию «пернициозиформной». В биоптатах костного мозга на ранних стадиях заболевания выявляются гиперклеточные участки активного резидуального кроветворения, которые исчезают по мере прогрессирования заболевания.

Основной группой препаратов, позволяющих улучшить прогноз при анемии Фанкони, являются андрогены. При лечении андрогенами гематологический ответ, проявляющийся через 1-2 месяца, получают приблизительно у 50\% больных, вначале происходит повышение количества лейкоцитов, а затем тромбоцитов, причём повышения количества тромбоцитов можно ожидать в течение 6-12 месяцев. После достижения гематологического улучшения дозу андрогенов следует постепенно снижать, не отменяя её полностью, поскольку отмена андрогенов практически у всех пациентов вызывает рецидив заболевания. При применении андрогенов у ответивших на лечение пациентов продолжительность жизни увеличивается: медиана продолжительности жизни составляет 9 лет после установления диагноза по сравнению с 2,5 годами соответственно для тех пациентов, у которых лечение андрогенами не было эффективным. Ранее в целях предотвращения несвоевременного закрытия зон роста совместно с андрогенами назначали преднизолон в дозе 5-10 мг через день, однако самостоятельного значения в лечении анемии Фанкони глюкокортикостероиды не имеют.

Единственным методом окончательного излечения гематологического синдрома при анемии Фанкони служит аллогенная трансплантация гемопоэтических стволовых клеток (ТГСК). Всего в мире проведено более 250 трансплантаций гемопоэтических клеток по поводу анемии Фанкони [4].

Прогноз анемии Фанкони неблагоприятный, особенно он ухудшается при развитии 
острого миелоидного лейкоза (ОМЛ). Консервативная терапия и трансплантация костного мозга помогают в 50\% случаев. Средняя продолжительность жизни пациентов - 30 лет. Как правило, летальный исход наступает в результате повышенной кровоточивости и присоединения оппортунистических инфекций на фоне угнетения иммунитета. Предупредить заболевание можно только с помощью медико-генетического консультирования при планировании беременности.

\section{Клиническое наблюдение}

Ребенок П., 5 лет, из цыганской семьи, находился на стационарном лечении в гематологическом отделении Коммунального некоммерческого предприятия «Городская клиническая детская больница №16» Харьковского городского совета с 14.11.16 по 06.12.16 с диагнозом: «Анемия Фанкони (конституциональная апластическая анемия). ХЗП III ст., ХПН II ст., врожденная аномалия развития органов МВС (агенезия левой почки - эхоскопически) со снижением СКФ. Функционирующее овальное окно. Примордиальный нанизм. Субклинический гипотиреоз. Задержка темпов физического развития. Хроническая герпесвирусная инфекция (герпес 6 типа). Токсический гепатит».

Ребенок впервые поступил в гематологическое отделение в феврале 2016 г. с жалобами на бледность кожных покровов, единичные «синячки» на нижних конечностях.

Из анамнеза жизни известно, что ребенок от 3 беременности, 3 родов, протекавших на фоне трихомонадного кольпита. Мать на учете не состояла. Роды в сроке 38 недель, масса тела 2,800 г, рост 45 см, оценка по шкале Апгар 5-7 баллов. Развивался с задержкой по весу и росту. Мать умерла, достоверная причина смерти неизвестна. Братья, со слов отца, здоровы. Из анамнеза заболевания известно, что мальчик болеет с 11.12.15, когда отмечалось повышение температуры, покашливание.

С 18.12.15 по 21.12.15 находился на лечении в Купянской ЦРБ по поводу анемии неясной этиологии тяжелой степени; ВПР, агенезии левой почки, деформации правой почки; задержки психофизического развития. Реконвалесцент трахеобронхита. В связи со снижением уровня Нв до 50 г/л для дальнейшего лечения и обследования был переведен в отделение интенсивной терапии (ОИТ) ХГДКБ № 16, где находился два дня. В ОИТ была проведена гемотрансфузия, для дальнейшего лече- ния ребенок переведен в педиатрическое отделение для детей старшего возраста, где находился до 28.12.15, генез анемии не был уточнен. Был выписан с улучшением под наблюдение участкового педиатра.

C 21.01.16 по 31.01.16 находился на повторном обследовании в педиатрическом отделении для детей старшего возраста. При поступлении общее состояние ребенка средней тяжести. В сознании, активен. Отмечается грубая задержка физического развития. Вес - 9400 г, рост - 80 см. Кожные покровы бледные, на нижних конечностях подкожные кровоизлияния разных размеров и степени зрелости, на коже бедер и живота единичные пигментные пятна светло-кофейного цвета. Аускультативно в легких жесткое дыхание, хрипов нет. Тоны сердца ритмичные, систолический шум на верхушке. Живот мягкий, безболезненный. Печень ниже края реберной дуги на 2,0 см, селезенка - у края реберной дуги. Микропенис, гипоплазия мошонки, яички не пальпируются. Стул, мочеиспускание в норме.

Исследование было выполнено в соответствии с принципами Хельсинкской Декларации. Протокол исследования одобрен Локальным этическим комитетом (ЛЭК) всех участвующих учреждений. На проведение исследований было получено информированное согласие родителей.

В клиническом анализе крови отмечалось снижение Нв до 73 г/л, эритроцитов до $2,7 \times 10^{12} /$ л, тромбоцитов до $30 \times 10^{9} /$ л, ускорение СОЭ до 21 мм/час. В динамике уровень Нв снизился до 60 г/л, была проведена повторная гемотрансфузия. Была заподозрена апластическая анемия. В миелограмме отмечалось малое количество клеточных элементов и незначительное раздражение эритронормобластического ростка кроветворения. Мегакариоциты - малое количество, зрелые без свободно лежащих тромбоцитов. Трепанобиоптат костного мозга - морфологическая картина наиболее соответствует апластической анемии. Группа крови - A (II) Rh+.

Мочевина крови, креатинин крови, функциональные пробы печени, сахар крови, острофазовые показатели, свободный Нв, сывороточное железо, К, Na, мочевая кислота крови, сахар мочи, копрограмма, 17-ОН-прогестерон, свободный тироксин, инсулиноподобный фактор роста, витамин В12, фолиевая кислота - в пределах нормы. ПЦР к герпесу 
6 типа и ВЭБ - пол., к ЦМВ - отр. Анализ крови на РМП маркеры вирусных гепатитов В и С, ВИЧ - отр. В протеинограмме гипопротеинемия, гипоальбуминемия, гипергаммаглобулинемия - 426,4 пг/мл (N 192-663). Эритропоэтин - $1004 \mathrm{ME} /$ мл (норма - 4,3-29). Клубочковая фильтрация снижена (56,7 мл/мин при норме 130-140), уровень цистатина C умеренно повышен (1,25 мг/л), что свидетельствует о нарушении фильтрационной функции почек.

Магнитно-резонансная томография головного мозга - очаговой патологии вещества головного мозга и патологических объемных образований не выявлено. Специфических феноменов на ЭЭГ не выявлено. Рентгенография органов грудной клетки, ЭКГ, УЗИ органов брюшной полости без патологии. Определяется функционирующее овальное окно, ложная хорда в полости левого желудочка, дефект межпредсердной перегородки, данных за легочную гипертензию нет; гипоплазия щитовидной железы, агенезия левой почки, яички в пахово-мошоночной области не лоцируются. Рентгенография верхних конечностей - в задне-передней проекции костный возраст соответствует возрасту 2-3 года. Проба с митомицином $\mathrm{C}$ : по результатам проведенного исследования выявлен повышенный уровень ломкости хромосом, который может определяться при анемии Фанкони. Количество выявленных аберраций наиболее соответствует возможной мозаичной форме. Молекулярноцитогенетическое исследование костного мозга (FISH) не выявило хромосомных нарушений.

Ребенок консультирован невропатологом, эндокринологом, нефрологом, инфекционистом, генетиком.

Проведено лечение: трансфузия эритроцитов №3 10 мл/кг, тромбоцитов №7 10 мл/кг, сандиммун 50 мг/сут, затем данабол 1,25-2,5 мг через день в течение 14 дней, тироксин 25 мкг/сутки. На фоне приема данабола отмечалось развитие токсического гепатита, выраженное повышение азотистых шлаков, нарушение общего состояния в виде агрессии, снижения аппетита, нарастание панцитопении в динамике, в связи с чем препарат был отменен и вновь назначен сандиммун.
Проведено типирование родственников ребенка для возможности проведения трансплантации костного мозга - выявлено два родственных донора (брата). В 2016 г. консультирован завотделения трансплантации костного мозга (г. Киев): пациент имеет показания к аллогенной трансплантации гемопоэтических стволовых клеток (алло-ТГСК) и в первую очередь - от HLA-идентичного семейного донора. Однако на сегодняшний день по результатам уже проведенных исследований пациент имеет и абсолютные противопоказания к проведению алло-ТГСК (не столько непосредственно к алло-ТГСК, сколько к миелоаблятивному режиму предтрансплантационного кондиционирования, который является единственно возможным при анемии Фанкони). Абсолютными противопоказаниями к алло-ТГСК на данный момент являются резко выраженная гипотрофия (в 5 лет ребенок весит 10 кг при минимально допустимой массе тела 14,8 кг; оптимум 20 кг), снижение клубочковой фильтрации более чем в два раза от нижней границы нормы (56,7 мл/мин. против 130-140 в норме) и активная HHV-6 инфекция (по данным ПЦР).

В настоящее время получает тироксин 25 мкг 1 раз в сутки утром натощак, холосас 1/4 ч. л. 3 раза в сутки внутрь, карболайн 1 ч. л. 3 раза в сутки внутрь, галстена 4 капли 3 раза в сутки, тиотриазолин по 1/4 таб. 2 раза в сутки.

\section{Выводы}

1. На сегодняшний день критериями диагноза анемии Фанкони являются данные, подтверждающие гиперчувствительность клеток больных к митомицину C или к DEB, или данные молекулярного анализа комплементарной группы на основе анализа имеющихся мутаций гена.

2. Постановка диагноза анемии Фанкони требует проведения тщательной дифференцировки с другими формами апластической анемии.

3. Излечения гематологического синдрома при анемии Фанкони можно добиться только с помощью алло-ТГСК.

Авторы заявляют об отсутствии конфликтов интересов. 


\section{ЛИТЕРАТУРА}

1. Alter BP, Hanenberg H., Kinsey S. (2014). Hematologic Abnormalities in Patients with Fanconi Anemia. In: Fanconi Anemia: Guidelines for Diagnosis and Management, 4th ed. Frohnmayer D, Frohnmayer L, Guinan E. Oregon (Eds.), Fanconi Anemia Research Fund, Inc, Eugene:43-73.

2. Alter BP. (2017). Inherited bone marrow failure syndromes: considerations pre- and posttransplant. Blood. 130 (21):2257-2264.

3. Bogliolo M, Schuster B, Stoepker C, Derkunt B, Su Y, Raams A, Trujillo JP, Minguillon J, Ramirez MJ, Pujol R, Casado JA, Banos R, Rio P, Knies K, Zuniga S, Benitez J, Bueren JA, Jaspers NG, Scharer OD, de Winter JP, Schindler D, Surralles J. (2013). Mutations in ERCC4, encoding the DNA-repair endonuclease XPF, cause Fanconi anemia. Am J Hum Genet. 92:800-6.

4. Bonfim C, Riberio L, Nichele S, Loth G, Kuwahara C, Koliski A, Bitencourt M, Scherer F, Rodrigues L, Pilonetto D, Pasquini R. (2015). Excellent outcomes for Fanconi anemia patients undergoing hematopoietic stem cell transplantation (HSCT) without radiation: a single center experience on 103 patients. Biol Blood Marrow Transplant. 21:S94a.
5. Chirnomas SD, Kupfer GM. (2013). The inherited bone marrow failure syndromes. Pediatr Clin North Am. 60:1291.

6. Guo $\mathrm{Y}$, Kartawinata M, Li J et al. (2014). Inherited bone marrow failure associated with germline mutation of $\mathrm{ACD}$, the gene encoding telomere protein TPP1. Blood. 124:2767.

7. Rose SR, Kim MO, Korbee L, Wilson KA, Douglas Ris M, Eyal O, Sherafat-Kazemzadeh R, Bollepalli S, Harris R, Jeng MR, Williams DA, Smith FO. (2014). Oxandrolone for the treatment of bone marrow failure in Fanconi anemia. Pediatr Blood Cancer. 61:11-9.

8. Sawyer SL, Tian L, Kahkonen M, Schwartzentruber J, Kircher M., University of Washington Centre for Mendelian Genomics. FORGE Canada Consortium, Majewski J, Dyment DA, Innes AM, Boycott KM, Moreau LA, Moilanen JS, Greenberg RA. (2015). Biallelic mutations in BRCA1 cause a new Fanconi anemia subtype. Cancer Discov. 5:135-42.

9. Yoon BG, Kim HN, Han UJ et al. (2014). Long-term follow-up of Fanconi anemia: clinical manifestation and treatment outcome. Korean J Pediatr. 57(3):125-34.

\section{Сведения об авторах:}

Макеева Наталия Ивановна - д.мед.н., проф., зав. каф. педиатрии №2 Харьковского НМУ. Адрес: г. Харьков, просп. Науки, 4; тел. (0572) 95-40-93. Одинец Юрий Васильевич - д.мед.Н., проф. каф. педиатрии №2 Харьковского НМУ. Адрес: г. Харьков, просп. Науки, 4; тел. (0572) 95-40-93. Поддубная Ирина Николаевна - к.мед.Н., доц. каф. педиатрии №2 Харьковского НМУ. Адрес: г. Харьков, просп. Науки, 4; тел. (0572) 95-40-93. Статья поступила в редакцию 17.07.2018, принята к печати 24.11.2018.

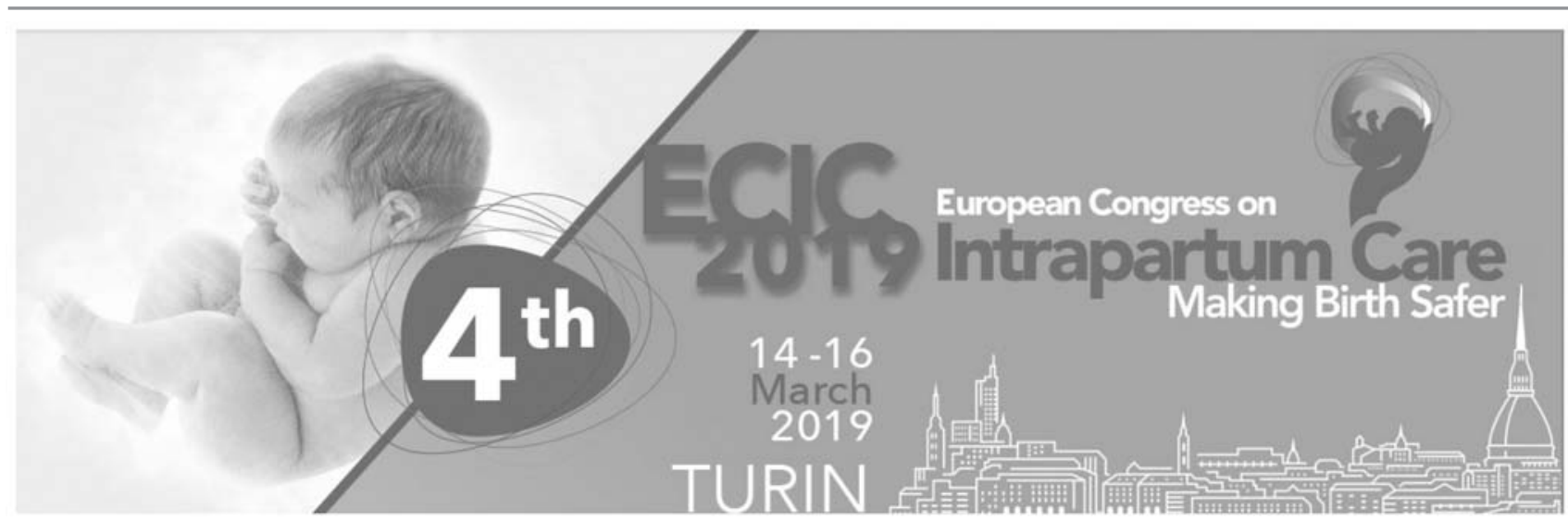

Main topics:

- Setting the scene of birth in Europe

- Women centred care

- Induction and augmentation of labour

- Labour in specific situations
- Intrapartum clinical targets

- Maternal morbidities \& mortality

- Intrapartum care

- Improving organization and teamwork in labour care

\section{Precongress courses}

\section{- HANDS-ON TRAINING COURSE 1}

Training of vacuum, forceps, and shoulder dystocia

\section{- HANDS-ON TRAINING COURSE 2}

Repair of 3rd and $4^{\text {th }}$ degree tears

- HANDS-ON TRAINING COURSE 3

Neonatal Resuscitation

- PRE-CONGRESS COURSE 1

FIGO intrapartum fetal monitoring course

\section{- HANDS-ON TRAINGING COURSE 4}

Ultrasound on the labour ward

\section{- HANDS-ON TRAINING COURSE 5}

Maternal Position in Labour

- HANDS-ON TRAINING COURSE 6

Post Partum Hemorrhage

More information: https://wror.mcascientificevents.eu/ecic 


\title{
О.І. Дорош', Л.С. Хім'як', О.В. Кушарська', І.Л. Василів ${ }^{1,2}$, І.П. Мелько ${ }^{1,3}$, А.М. Мих ${ }^{1,4}$ \\ Інвазивний мукормікоз: проблеми діагностики і лікування
}

\author{
'КНП ЛОР «Західноукраїнський спеціалізований дитячий медичний центр», м. Львів, Україна \\ ${ }^{2}$ Медичний центр «ОМЕГА», м. Київ, Україна \\ ${ }^{3} Ц$ ентр медичних інновацій NOVO, м. Львів, Україна \\ ${ }^{4}$ Медичний центр Святої Параскеви, м. Львів, Україна
}

SOVREMENNAYA PEDIATRIYA.2018.8(96):70-86; doi 10.15574/SP.2018.96.70

\begin{abstract}
Наведено клінічний випадок інвазивного мукормікозу у 7-річного пацієнта з набутою важкою апластичною анемією, резистентною до імуносупресивної терапії, підтверджений результатами мікробіологічних досліджень, з ураженням паренхіми обох легень, селезінки та перфоративними дефектами діафрагми. Показано клінічні, мікробіологічні та радіологічні особливості перебігу інфекції. Розглянуто також інші інфекційні ускладнення, різноманіття спектра їхніх збудників і локалізації, які спостерігалися у пацієнта впродовж 4-місячного застосування імуносупресивної терапії. Подано короткий огляд літератури.

Ключові слова: діти, набута важка апластична анемія, імуносупресивна терапія, інвазивний мукормікоз, ускладнення.

\author{
Invasive Mucormycosis: Problems of Diagnosis and Treatment \\ O.I. Dorosh', L.S. Khimyak', O.V. Kusharska', I.L. Vasyliv' ${ }^{12}$ I.P. Melko ${ }^{1,3}$ A.M. Mykh ${ }^{1,4}$ \\ ${ }^{1}$ Communal noncommercial enterprise of Lviv regional council «Western Ukrainian Specialized Children's Medical Centre» Lviv, Ukraine \\ 2Medical center «OMEGA», Kyiv, Ukraine \\ ${ }^{3}$ Center for Medical Innovations NOVO, Lviv, Ukraine
}

${ }^{4}$ Medical Center of St. Paraskeva, Lviv, Ukraine
\end{abstract}

The publication describes a clinical case of invasive mucormycosis microbiologically confirmed, with lesions of the parenchyma of both lungs, spleen and perforation defects of the diaphragm, its clinical, microbiological and radiological features in a 7-year-old patient with acquired severe aplastic anemia resistant to immunosuppressive therapy. Other infectious complications are also presented in this paper, with a variety of pathogens and localizations that were observed in the patient during a 4-month treatment of immunosuppressive therapy, with a literature review.

Key words: children, acquired severe aplastic anemia, immunosupressive therapy, invasive mucormycosis, complications.

\author{
Инвазивный мукормикоз: проблемы диагностики и лечения \\ О.И. Дорош', Л.С. Химьяк', А.В. Кушарська', ИЛ. Васылив ${ }^{12}$, И.П. Мелько ${ }^{1,3}$, А.Н Мых ${ }^{1,4}$ \\ ${ }^{1}$ КНП ЛОС «Западноукраинский специализированный детский медицинский центр», г. Львов, Украина \\ "Медицинский центр «ОМЕГА», г. Киев, Украина \\ ${ }^{3}$ Центр медицинских инноваций NOVO, г. Львов, Украина \\ ${ }^{4}$ Медицинский центр Святой Параскевы, г. Львов, Украина
}

Приведен клинический случай инвазивного мукормикоза у 7-летнего пациента с приобретенной тяжелой апластической анемией, резистентной к иммуносупрессивной терапии, подтвержденый результатами микробиологических исследований, с поражением паренхимы обеих легких, селезенки и перфоративными десректами диафрагмы. Показаны клинические, микробиологические и радиологические особенности течения инфрекции. Также описаны другие инфекционные осложнения, с многообразным спектром возбудителей и локализации, которые наблюдались у пациента в течение 4-месячного применения иммуносупрессивной терапии. Подан краткий обзор литературы.

Ключевые слова: дети, приобретенная тяжелая апластическая анемия, иммуносупрессивная терапия, инвазивный мукормикоз, осложнения.

\section{Вступ}

А пластична анемія (АА) - захворювання, що характеризується панцитопенією внаслідок пригнічення кістково-мозкового кровотворення. Поряд із геморагічним та анемічним синдромами клінічну картину хвороби визначають різні інфекційні ускладнення. При АА, незалежно від форми (набута чи спадкова) та важкості захворювання, спостерігається затяжний період нейтропенії. Відомо, що при зниженні кількості нейтрофільних гранулоцитів менше 0,5х109/л суттєво зростає ризик інфікування, важкість перебігу якого визначається тривалістю гранулоцитопенії. Впродовж декількох місяців, навіть максимально ефек- тивної терапії АА, у пацієнтів спостерігається стан глибокої імуносупресії, зумовлений як аплазією кістково-мозкового кровотворення, так і специфічною терапією. Довготривале застосування імуносупресивних препаратів, які використовуються у терапії АА, також сприяе розвитку загрозливих інфекційних бактеріальних та грибкових ускладнень. Упродовж останніх 20-ти років застосовуються нові терапевтичні підходи до лікування АА, включаючи трансплантацію кісткового мозку (ТКМ) та імуносупресивну терапію (ICT), завдяки яким 5-річна виживаність хворих на АА збільшилася до $70,0-80,0 \%$. Проте основною причиною смертності у цій популяції хворих залишають- 
ся інфекційні ускладнення [94]. На тлі комбінованої антибактеріальної терапії причиною інфекційних процесів все частіше є патогенні мікроорганізми, зростає роль грибів як причини інфікування. Зокрема у пацієнтів із АА реєструється рідкісна інвазивна грибкова інфекція з високим рівнем смертності - мукормікоз (МM) [6,8,9,10,14,31,36,42,52,53,56,58, $59,61,63,68,71,76,85,89,93-95,103,104]$.

На нашу думку, повідомлення про ряд важких інфекційних ускладнень, які виникали упродовж 4-х місяців перебування пацієнта, хворого на важку набуту АА, у нашому центрі 3 демонстрацією типів патогенних мікроорганізмів, зокрема діагностований мікробіологічно інвазивний ММ з ураженням паренхіми обох легень, селезінки й діафрагми, аналіз ряду досліджень особливостей інфекцій, які супроводжують пацієнтів із цією нозологією, $\epsilon$ цікавим і корисним для лікарів різних спеціальностей.

Mema дослідження - представити характер ускладнень, включаючи інвазивний мікоз, які супроводжують хворого на АА в умовах сучасної програмної терапії.

\section{Опис клінічного випадку}

Хлопчик 7-и років захворів у січні 2018 р., коли з'явилися біль у животі, пожовтіння шкіри. Лікувався у відділенні педіатрії у січні та лютому 2018 р. з приводу гепатиту нез'ясованої етіології, оскільки маркери вірусних гепатитів A, B, С були негативними. Отримував упродовж місяця, з огляду на гіпербілірубінемію та гіпертрансфераземію, солумедрол в дозі 1 мг/кг. У квітні 2018 р. спостерігалися наростаюча загальна слабкість, блідість шкірних покривів з геморагічним висипом, виявлено панцитопенію. Діагностовано набуту важку АА, асоційовану із парвовірусом B19 (Parvovirus B19) та вірусним гепатитом А. У сироватці крові виявлено парвовірус B19 IgG 2,33 од/мл IgM 0,39 од/мл (норма $<0,8)$, ПЛР 0,63x105, DNA 1,81х105 копій вірусних; вірус гепатиту A IgM 0,343 од/мл, HAV IgG 20,52 од/мл (норма <20,0). Серологічні маркери HBV, HCV, CMV, EBV - негативні. Діагноз АА верифікований двома незалежними гістологічними лабораторіями. У референслабораторії НДСКЛ «ОХМАТДИТ» (м. Київ) проведено молеку лярно-генетичне та фенотипове дослідження, виключено мієлодиспластичний синдром та пароксизмальну нічну гемоглобінурію.
24.04.2018 р. розпочато ICT EWOG-SAA 2010 (антитимоцитарний глобулін конячий (АТГАМ) (24.04.18-1.05.2018), циклоспорин (CSA), солумедрол, яку завершено 22.05 .18 р. Упродовж ICT проводилася профілактична терапія пневмоцистної пневмонії - бісептол тричі на тиждень, мікозу - ітраконазол (орунгал), селективна деконтамінація кишечника ніфуроксазид. ICT ускладнювалася транзиторним зниженням темпу діурезу на грунті підвищеного рівня CSA у сироватці крові, вторинною артеріальною гіпертензією, гіперпластичним гінгвітом, гіпертрихозом.

Відразу після завершення 28-денного курсу солумедролу у хлопчика з'явилися незначний параорбітальний набряк та біль у ділянці виходу 1-ї гілки трійничного нерва зліва. Виключався синусит. На рентгенографії (РТГ) придаткових пазух носа патології не виявлено. Консультований неврологом та оториноларингологом. Призначено місцеву терапію з позитивним ефектом: полідекса, протаргол $2 \%$, дефлю-синус мазь у ніс, нурофен. Упродовж перших 1,5 міс. проведення ICT були короткочасні епізоди гіпертермії, зумовлені у квітні бактеріемією E. coli та у травні St. haemolyticus, афтозний стоматит (Str. viridans, Enterococcus spp., C. pseudodiphteriae), які успішно подолані внаслідок застосування антибактерійних засобів. У загальному аналізі крові (ЗАК) утримувалася глибока трипаросткова цитопенія, впродовж усього періоду госпіталізації спостерігалася лейкопенія у межах 0,01-0,41 Г/л, агранулоцитоз. У зв'язку 3 гемотрансфузійною залежністю розвинувся вторинний посттрансфузійний гемосидероз (у сироватцікрові Fе 33,0-56,4 мкмоль/л, феритин 1269,0-4150,0 нг/мл), що вимагало постійної десфералотерапії (застосовувався препарат дефероксаміну ексіджад).

3 початку червня 2018 р. зафіксовано гіпертермію, яка важко та короткочасно коригувалася антипіретиками. У посіві крові на гемокультуру - St.haemolyticus, у бакпосіві сечі $-E$. coli, калу - Klebsiella pn, з ротової порожнини та зіва - Str. viridans, Enterococcus spp., C. pseudodiphteriae, Enterobacter aerogenes. Прокальцитонін у крові - 0,107-0,148 нг/мл (у межах норми до 0,046). Первинно при ультразвуковому дослідженні (УЗД) змін не було. Незважаючи на інтенсивну антибактеріальну, згідно із бакпосівами та чутливістю до антибіотиків, та протигрибкову терапію (орунгал емпірично було замінено на каспофунгін (кансідаз), стан дитини не покращувався. На 5-у добу гіпер- 


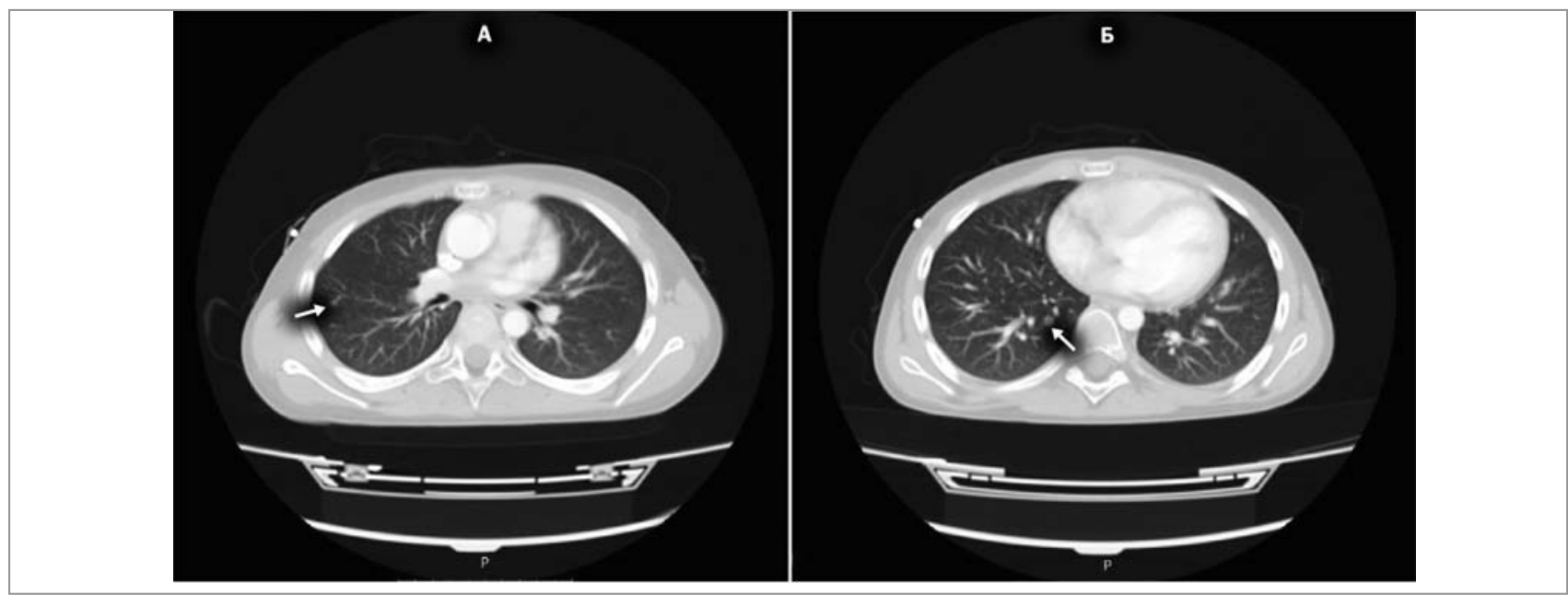

Pис. 1. Мікотичне ураження паренхіми легень, КТ №1 від 11.06.2018 р.

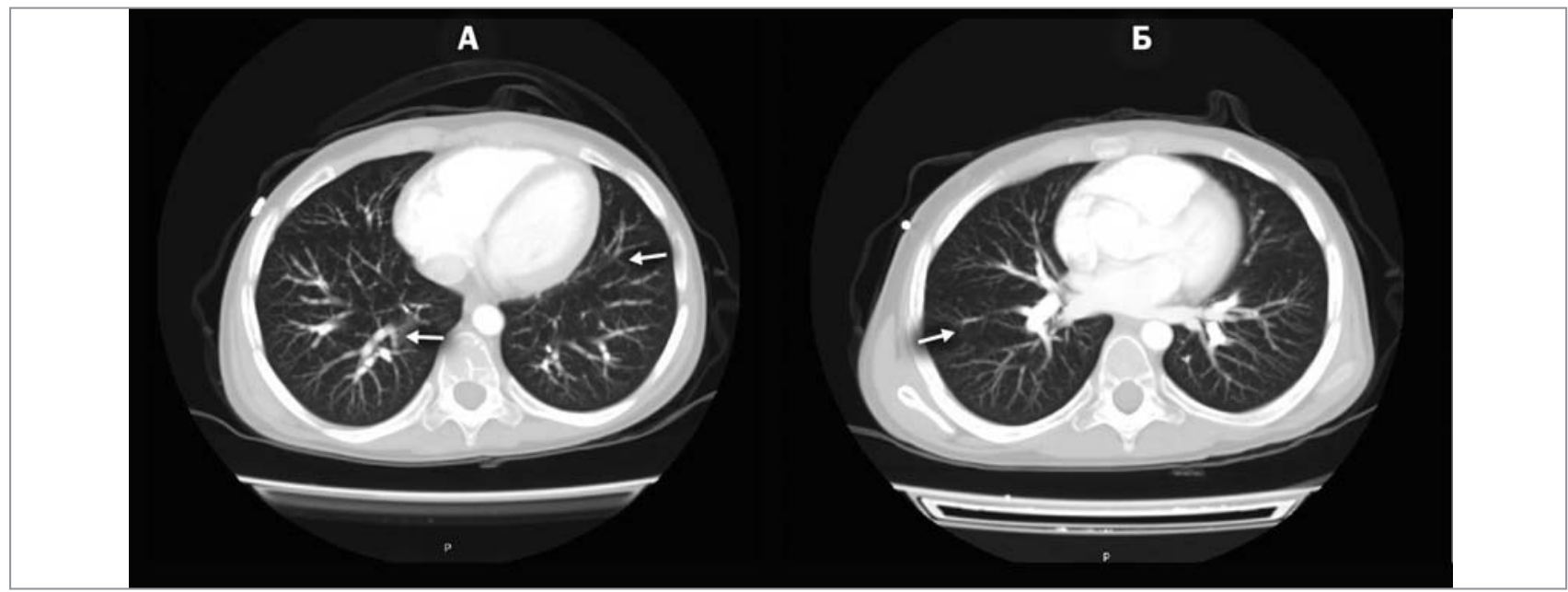

Pис. 2. Мікотичне ураження паренхіми легень у динаміці, КТ №2 від 03.07.2018 р.

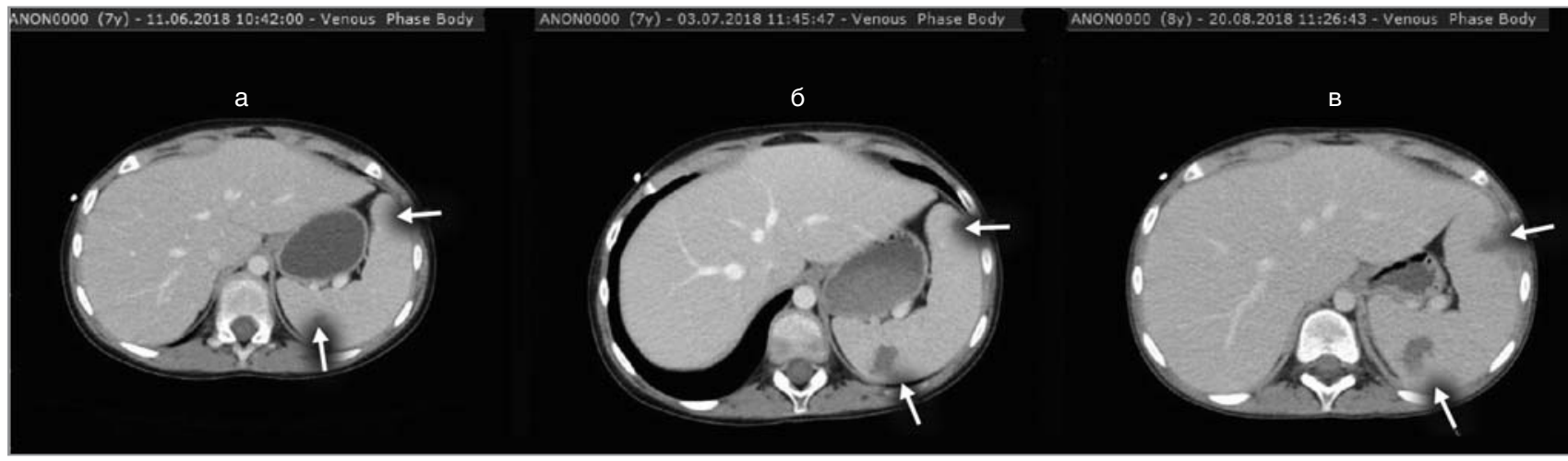

Pис. 3. Динаміка мікотичного ураження у паренхімі селезінки: а — КТ від 11.06 .2018 р.; б — КТ від 03.07 .2018 р.; в — КТ від 20.08.2018 p.

термічного синдрому виконано комп'ютерну томографію (КТ) органів грудної клітки та черевної порожнини з метою виключення системного мікозу. На КТ (11.06.18) виявлено у S6 правої легені два поодинокі дрібні вогнища $\mathrm{d}-2-4$ мм, у S5 аналогічне вогнище до 3-х мм. Селезінка містила два кистоподібні утворення розмірами до 7 мм, одне з яких було субкапсульним. Печінка без структурних змін (рис. 1 а, б; 3 а). Запідозрено системний мікоз, відмінено ICT -
CSA. Тест крові на Aspergillius antigen (EIA) двічі негативний (у червні 2018 р. 0,31 та у липні 2018 p. - 0,10 $(\mathrm{n}<0,5)$. Відмінено ICT CSA. Терапію протигрибковими препаратами застосовували емпірично, оскільки при мікробіологічному дослідженні не виявляли грибків.

Стан пацієнта не покращувався. Продовжувалася лихоманка, наростали ознаки загальної інтоксикації, з'явилися діастолічні розлади 


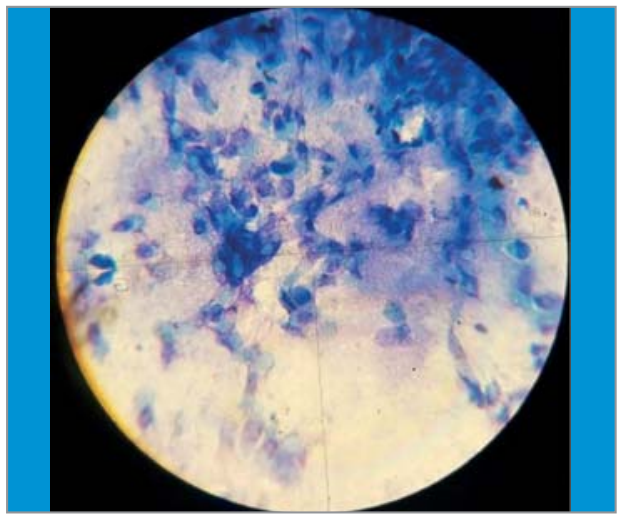

Pис. 4. У нативному мазку з бронхолегеневого лаважу (змиву) короткі широкі гіфи Mucorales

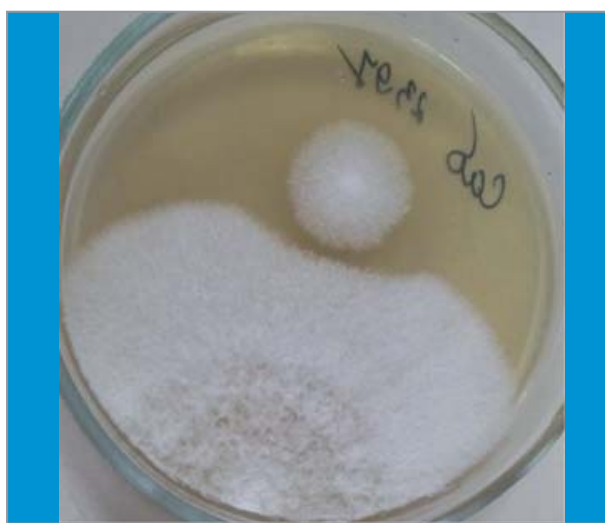

Рис. 5. Колонії Mucorales на середовищі Сабуро (пухнасті, нагадують войлок)

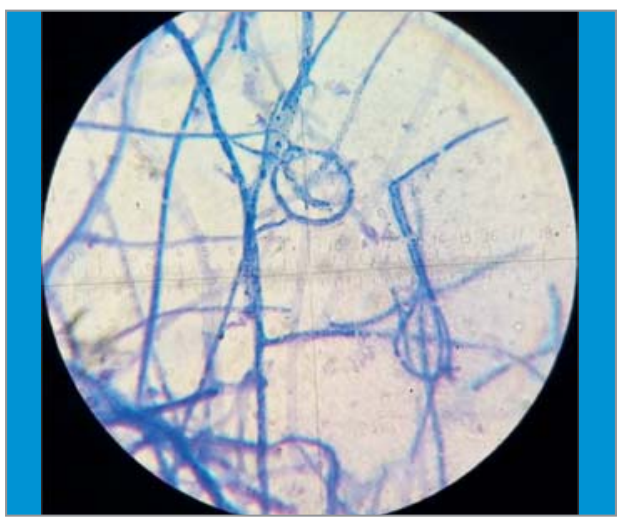

Рис. 7. Міцелій зігоміцетів Mucorales (несептований або нерівномірно і рідко септований) Забарвлення - метиленовим синім, збільшення х 800

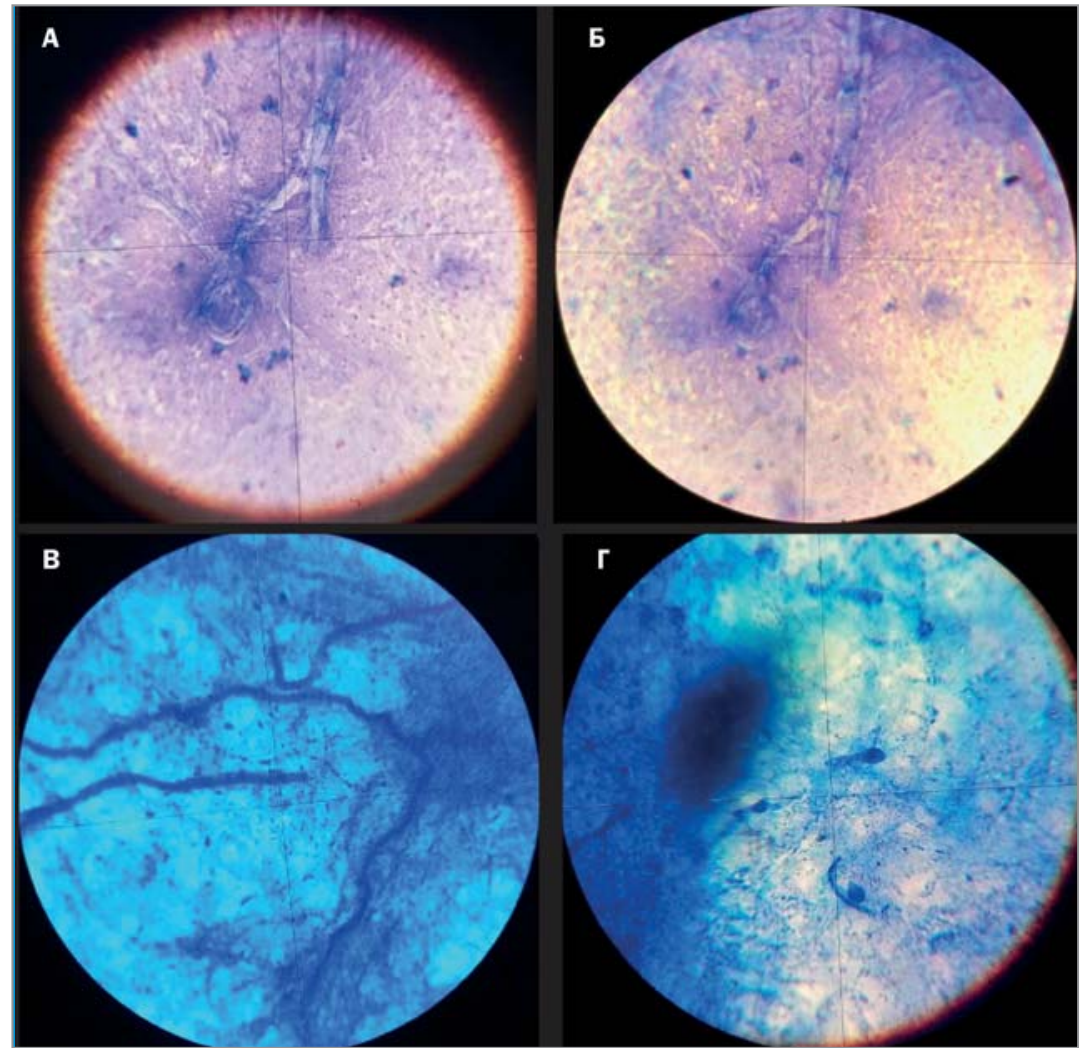

Pис. 6. Мікроморфологія Mucorales: привертає увагу фрорма спорангіїв мішкоподібні із спорангіоспорами всередині

(рис. а, б), розгалуження ниток, які їх несуть (в), дрібні розміри спорангіїв (г). Забарвлення — метиленовий синій, збільшення х 800

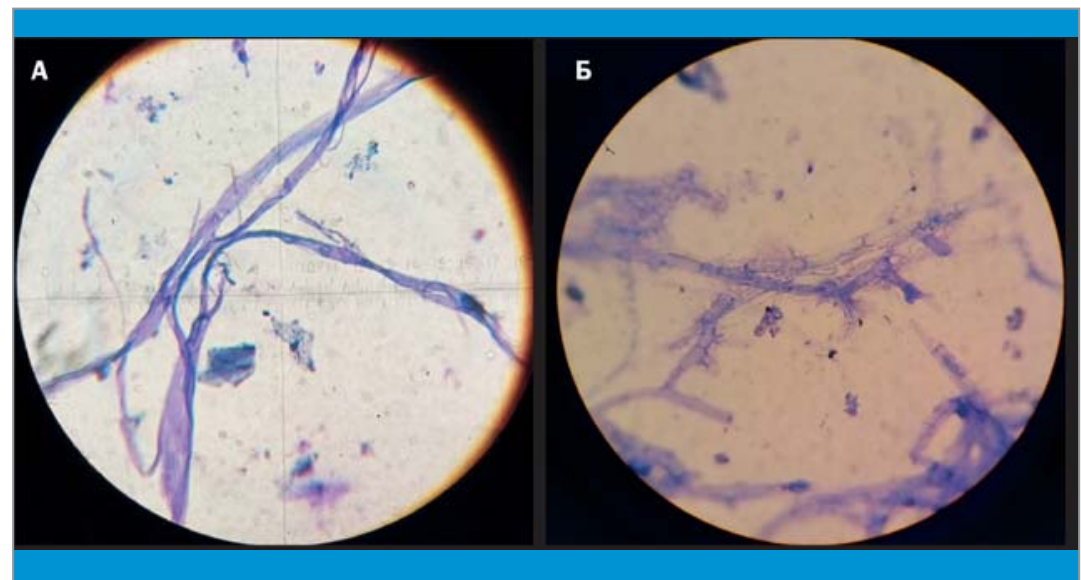

Pис. 8. Гіфри і ризоїди Mucorales. Забарвлення — метиленовий синій, збільшення x800 за результатами ехокардіографії (Ехо-КГ). У посіві крові на стерильність виявлено E. coli, яку було подолано. Згодом каспофунгін було замінено на амфоліп (ліпідасоційована форма амфотерицину В: містить протигрибкову сполуку амфотерицину В у комплексі з фосфоліпідами), застосування якого супроводжувалося важкою піретичною реакцією з порушенням гемодинаміки, колапсом. Препарат відмінено на 3-ю добу. Наступними протигрибковими засобами були позаконазол (ноксафіл), мікофунгін (мікамін), повторно каспофунгін (кансідаз).

Призначене лікування не давало бажаного ефекту, у хлопчика не припинялася лихоманка до високофебрильних цифр. У повторному посіві крові на гемокультуру - St. haemolyticus. Через чотири тижні повторно виконано КТ, яка 
виявила наростання розмірів та кількості вогнищ у паренхімі легень та селезінки, помірну гепатоспленомегалію (рис. 2 а, б; 3 б).

Від діагностично-санаційної бронхоскопії (БС) батьки відмовлялися тривалий час. Аускультативно в нижніх відділах лівої легені виявлено ослаблене дихання. РТГ та УЗД зафіксували випіт у лівому плевральному синусі, наростання гепато- $(+10,0$ см) та спленомегалії (+9 см з-під краю реберної дуги).

Згоду на БС отримано лише на 10-у добу після другого обстеження КТ. Макроскопічно змін не було. Мікробіологічне дослідження промивних вод бронхів виявило значний спектр мікроорганізмів: St. haemolyticus, E. coli, Lactobacillus spp., Enterococcus spp., Corynebact. pseudod., Mucorales spp. (рис. 4, 5, 6 а-г; 7; 8 а, б), з підросту Enterobacter aerogenes. Водночас із зіва висівався Mucorales spp. (рис. 9), Str. viridans, Enterobacter aerogenes.

У пацієнта виключався туберкульоз: квантіфероновий тест мав негативний результат, тестом Xpert MTB-RIF Assay G4 у промивних водах бронхів мікобактерій туберкульозу не виявлено.

Згідно з рекомендаціями EGIL [84,93] щодо терапії ведення системних мікозів грибами типу мукоралєс відмінено дефероксамін, який застосовувався з приводу перевантаження залізом на фоні гемотрансфузійної залежності. Відповідно до чутливості мікроорганізмів за результатами посівів застосовувалася антибактерійна комбінована терапія, яка включала: кубіцин, метронідазол, ауротаз, амікацин, ципрофлоксацин, меропенем, цебопім, авелокс, зівокс, коломіцин, фосфоміцин, ванкоміцин, інванз. Інтенсивна терапія включала також довенний людський імуноглобулін (біовен-моно 5\%, октагам 10\%), гранулоцитарні фактори росту, парентеральне живлення.

Протигрибкові ліки призначено згідно із чутливістю у комбінації амфоліп + воріконазол (рис. 10). Застосування амфоліпу в комбінації 3 воріконазолом супроводжувалося гіпокаліємією (максимальне зниження $\mathrm{K}+$ до 2,2 ммоль/л), токсичною гепатопатією (з максимальним підвищенням загального білірубіну до 52,2 мкмоль/л). Другий курс амфоліпу тривав 13 днів. Після його відміни внормувалися показники функції печінки, скореговано гіпокаліємію.

Згодом пацієнта почали турбувати біль та дискомфорт у періанальній ділянці, викликані тріщиною анального отвору. Через два тижні з'явилися ознаки періанального дерматиту, з формуванням запального інфільтрату у періанальній ділянці та правій сідниці, який через тиждень саморозкрився з утворенням норицевого ходу (рис. 11). У бакпосіві зі шкіри у періанальній ділянці та норицевого ходу запального інфільтрату - Enterobacter aerogenes.

На фоні призначеної терапії утримувалися гіпертермія, артеріальна гіпертензія, наростала загальна інтоксикація. Хворого турбували виснажливі нудота та блювання, періодично біль у лівому підребер'ї. Розглядалася можливість поширення мікотичного ураження на шлунково-кишковий тракт (ШКТ), центральну нервову систему (ЦНС) та токсична дія медикаметів. На МРТ голови виявлено ознаки лікворної дисциркуляції, вогнищевих змін та грибкового ураження не знайдено. Виконано діагностичну люмбальну пункцію, ліквор витікав повільними краплями. Аналіз ліквору: ліквор безбарвний, прозорий, цитоз $3 \times 10^{6} /$ л, білок - 0,165 г/л, у цитоспіні клітин не виявлено. Посів ліквору не дав росту. На езофіброгастродуоденоскопії (ЕФГДС) ознаки еритематозної гастропатії, дуодено-гастральний та гастро-езофагальний рефлюкс. Встановлено назо-гастро-дуоденальний зонд. У бакпосіві шлунково-дуоденального вмісту виявлено Enterobacter aerogenes. Однак блювання утримувалося поза зондом. Харчування пацієнта забезпечувалося збалансованими сумішами через зонд та цілодобовим парентеральним живленням.

У середині серпня, незважаючи на застосоване лікування, відбулося різке погіршання загального стану: наростання серцево-судинної недостатності I-II А ст., дихальної недостатності I-II ст. Констатовано анасарку з периферичними набряками. На Ехо-КГ легенева гіпертензія I ст., гідроперікард. Гідроторакс на РТГ (рис. 12). За важкістю стану хворий переведений у відділення інтенсивної терапії та реанімації, де перебував дві доби.

За час госпіталізації стан дитини залишався важким за рахунок септико-токсичних ускладнень комбінованого бактерійно-грибкового генезу, системного мікозу (Mucorales) 3 негативною динамікою, відзначеною на КТ у серпні 2018 р. (ураження паренхіми обох легень, нижньочасткова деструктивна пневмонія з формуванням абсцесу в S10 лівої легені, локальне розплавлення діафрагми, абсцеси селезінки, сплено-пульмональна фістула, гепатоспленомегалія (рис. 3 в; 13 а-г). Консилярно прийнято рішення продовжити консервативне 


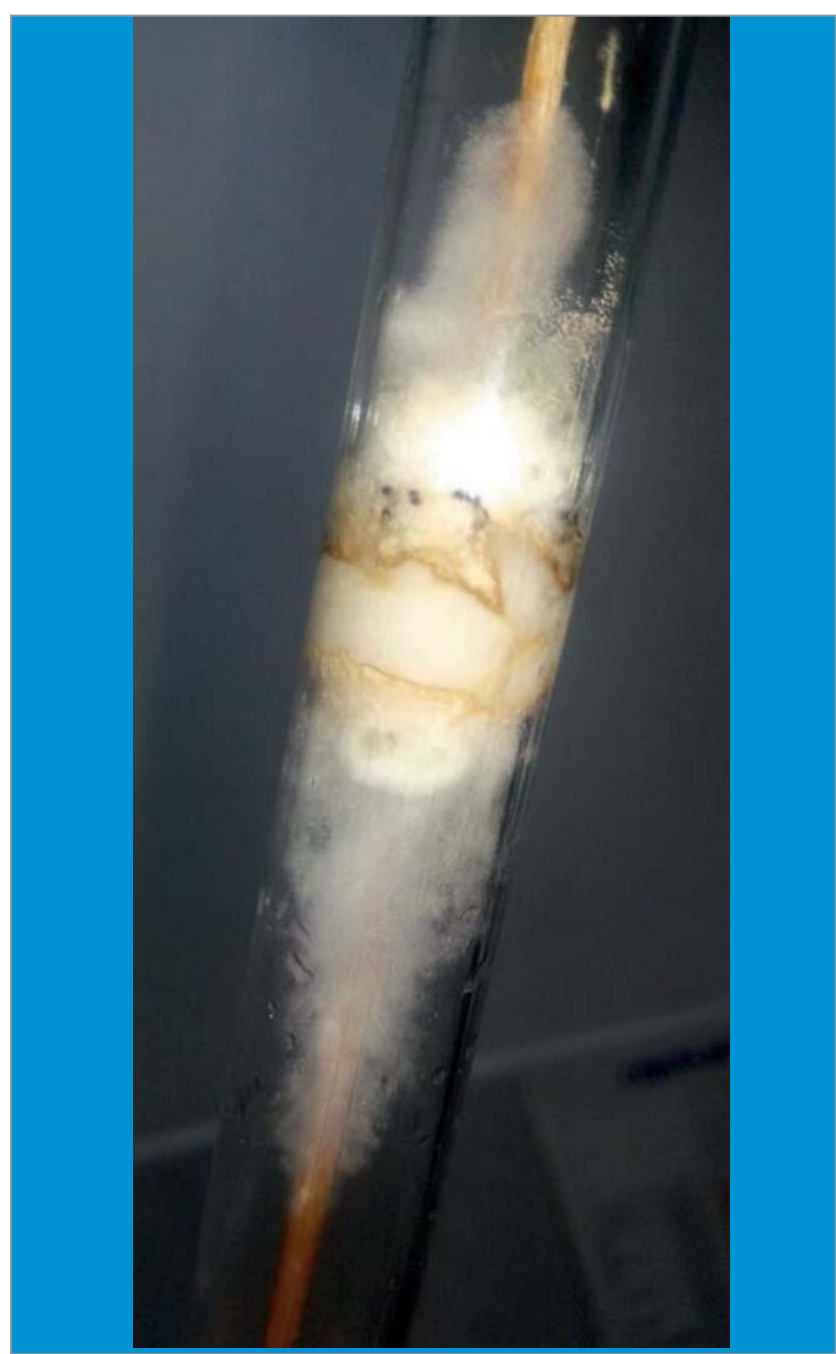

Pис. 9. Сполонги (гіфи повітряного міцелію) Mucorales на тампоні з рідкого агару Сабуро (мазок із зіва)

багатокомпонентне лікування, оскільки хірургічне втручання має високий ризик для життя пацієнта.

У динаміці: запальний інфільтрат з ураженням періанальної ділянки та правої сідниці регресував, норицевий хід загоївся, зменшились розміри печінки до $+3,5$ см, селезінки +0,5 см 3-під реберної дуги, електролітні порушення (гіпокаліємія) скориговані, блювання утримувалося, артеріальний тиск контрольований, гіпертермія до двох разів на добу, максимально утримувалося аускультативно ослаблене дихання в нижніх відділах лівої легені, рефрактерна форма важкої набутої АA до протокольної ICT, гемотрансфузійна залежність (за період з 3.04.2018 р. до 28.08.2018 р. госпіталізації у нашому центрі пацієнт отримав 70 доз тромбоконцентрату та 31 дозу еритроконцентрату). У стабільному транспортабельному стані покинув наш Центр на вимогу

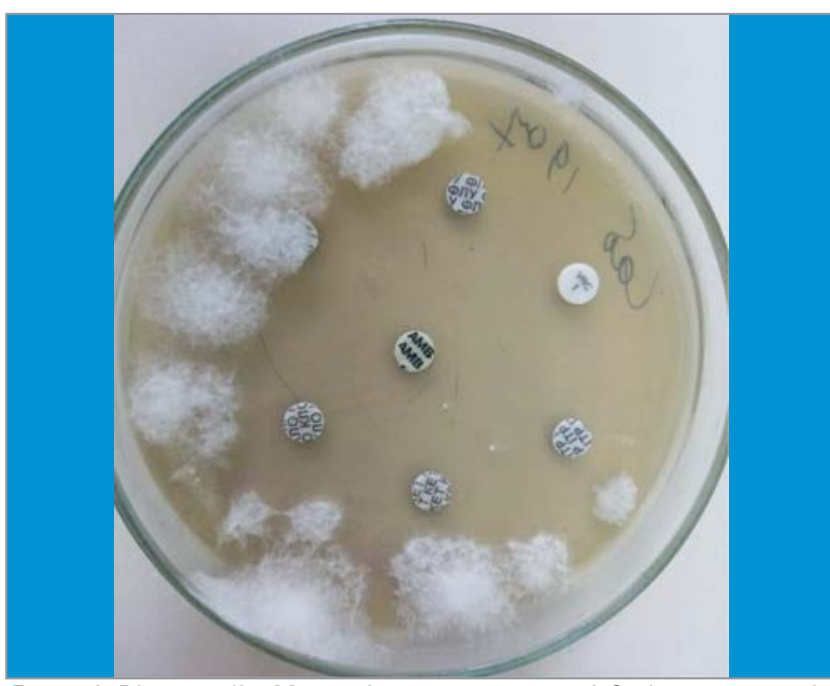

Pис. 10. Ріст грибів Mucorales на середовищі Сабуро з антимікотиками. Чутливість до воріконазолу та амфотеріцину В

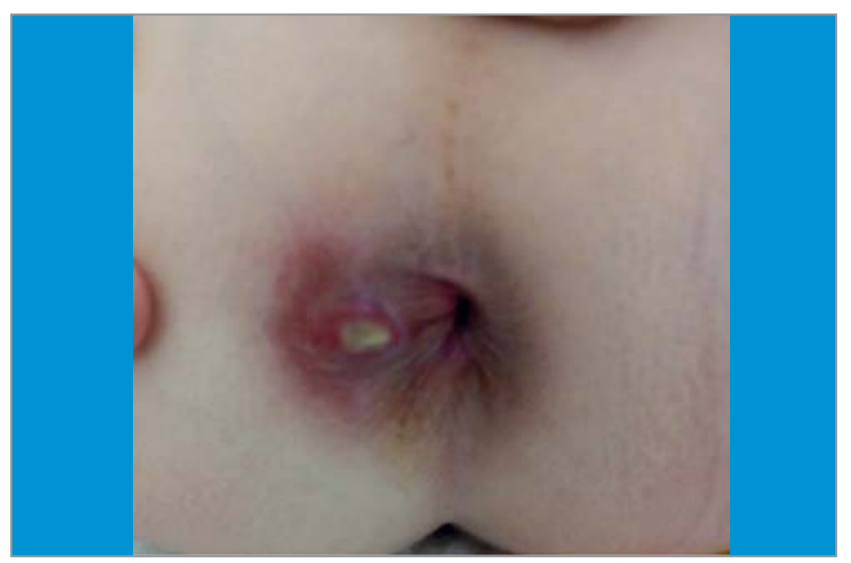

Pис. 11. Запальний інфільтрат у періанальній ділянці, викликаний Enterobacter aerogenes, у стадії розкриття та утворення норицевого ходу

батьків та продовжив лікування за кордоном. Після подолання інфекційного процесу готується до алогенної трансплантації гемопоетичних стовбурових клітин.

\section{Обговорення}

Інфекції, особливо - інвазивні мікози, залишаються основною причиною смертності у пацієнтів з АА. Одним із найважливіших ризиків інфікування у хворих на важку АА $€$ лейкопенія із нейтропенією i/або агранулоцитозом [31,42,58,59,63,94]. Захворювання та важкість інфекції обернено пропорційні абсолютному гранулоцитарному значенню [22]. Тривалість гранулоцитопенії також має важливий вплив на розвиток інфекційних ускладнень у цих хворих. Для пацієнтів з АА характерні періоди нейтропенії, які можуть тривати місяці або навіть роки [59,92]. У нашому повідомленні пацієнт з часу початку ICT перебував у аграну- 
лоцитозі із середньою тривалістю нейтропенії понад чотири місяці.

У терапевтичному підході для хворих на АА, яким не проводиться ТКМ, застосовується протокольна ICT, до складу якої входять різні імуносупресивні препарати, включаючи кортикостероїдні гормони, циклоспорин А (CSA), антитимоцитарний глобулін (АТГ) та антилімфоцитарний глобулін (АЛГ) [31,42,58,59,92]. Представлений пацієнт отримував ICT із комбінацією саме цих ліків. Доведено, що таке лікування є ефективним для більшості хворих на AA [31]. Тим не менше, ці медикаменти поглиблюють імунодефіцит, викликаний основним захворюванням. АТГ є потужним імунодепресивним агентом, який призводить до швидкого та глибокого виснаження лімфоцитів периферичної крові, що сприяє його загальному імунодепресивному впливу [30]. Комбінація АTГ та CSA є особливо шкідливою для функції Т-клітин, однак, на думку P. Ljung-

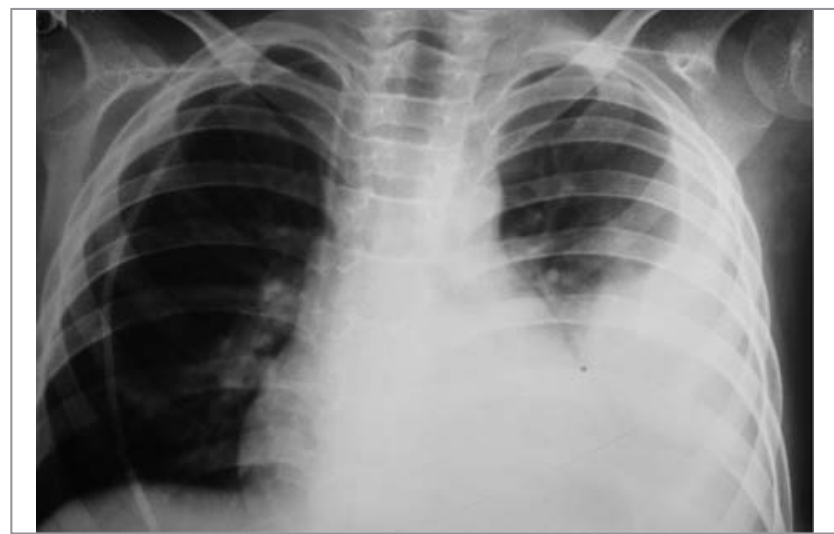

Pис. 12. Рентгенографія органів грудної клітки від 13.08 .18 р

man i співавт. (2000), поєднання цих медикаментів не означає, що збільшується ризик інфікування. Усім хворим на АА застосовується інтенсивна багатокомпонентна супровідна терапія [42]. Обов'язково такі особи (наш хворий - не виняток) отримують профілактично протигрибкові медикаменти, селективну

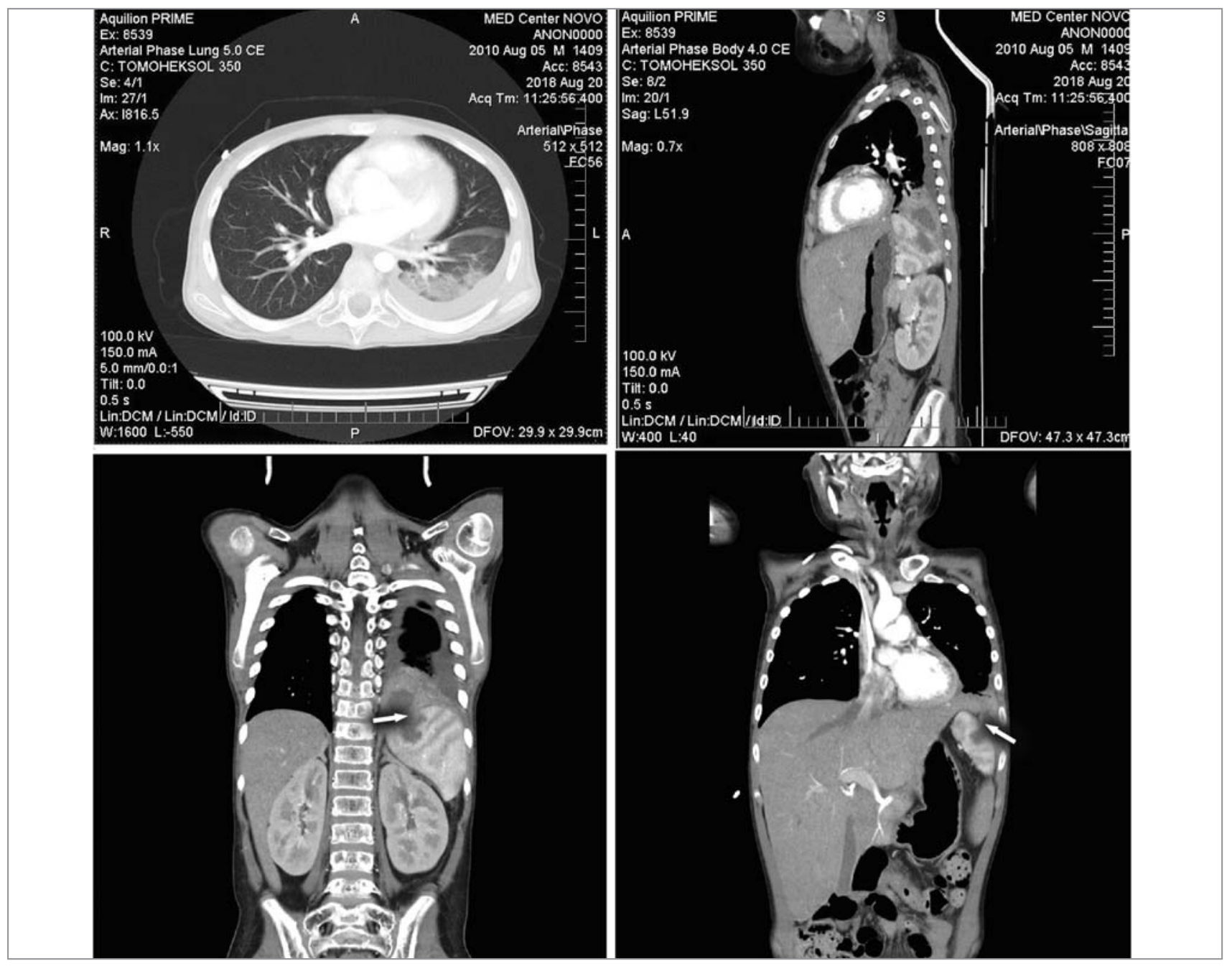

Pис. 13. КТ №3 від 20.08.2018 р. Розрішення некротичного вузла S10 правої легені (зазначено стрілками) 
деконтамінацію кишечника, бісептол як засіб проти пневмоцистної пневмонії, гранулоцитарні фактори росту, гемокомпонентну, інфузійну терапію тощо. Від адекватного призначення антибактеріальних, протигрибкових та зазначених засобів залежить своєчасність проведення етапів програмного лікування АА, а отже, і прогноз захворювання. Призначення в дебюті захворювання стероїдних гормонів неминуче призводить до виникнення інфекційних ускладнень [58,59]. Наш пацієнт з приводу гепатиту нез'ясованої етіології до діагностики АА отримував глюкокортикостероїди, що теж вплинуло в подальшому на його інфекційний статус.

Характер інфекційних процесів і спектр їхніх збудників змінюються з перебігом хвороби. На тлі поєднаної антибактеріальної терапії все більшого значення набувають умовно-патогенні мікроорганізми, зростає роль грибків як причини інфекції [9,10,22,23,31,42,58,59,63,94]. Упродовж перебування у стаціонарі нами зафіксовано, як змінювався спектр збудників у мікробіологічних дослідженнях. Виявлено бактеріємію грамнегативними (Г-) та грампозитивними $(\Gamma+)$ мікроорганізмами (E.coli, St. haemolyticus). Але на фоні призначеного лікування згодом відбувалася зміна $\Gamma^{+}$на Г-бактеріємію. Привертає увагу видове розмаїття виявлених мікробів: $\Gamma^{-}$із кишкової групи у бакпосівах сечі - E. coli, калу - Klebsiella pn; а також спектр патогенів з ротової порожнини та зіва Str. viridans, Enterococcus spp., C. pseudodiphteriae, Enterobacter aerogenes. Слід зазначити, що діапазон виявлених мікроорганізмів зі слизової оболонки ротової порожнини, як до початку ICT, так і на їі тлі, залишався практично незмінним: Str. viridans, Enterobacter aerogenes. Окрім бактеріємії згодом нами верифіковано інвазивний мікоз, викликаний надзвичайно агресивними грибками роду Mucorales. Такий мікоз є третьою найбільш поширеною інвазивною грибковою інфекцією після аспергільозу та кандидозу і становить 8,3-13,0\% усіх грибкових інфекцій, зафіксованих при аутопсії пацієнтів із гематологічними хворобами [62]. Мікробіологічне дослідження промивних вод бронхів виявило значний мікробіологічний спектр: St. haemolyticus, E. coli, Lactobacillus spp., Enterococcus spp., Corynebact. pseudod., Mucorales spp. (рис. 4-9), з підросту Enterobacter aerogenes. Водночас із зіва висівався Mucorales spp. (рис. 10), Str. viridans, Enterobacter aerogenes.

Першим ММ описав A. Paltauf у 1885 році [55]. Він частіше діагностується у осіб чолові- чої статі у співвідношенні 2:1 [86]. Вчені вважають, що такі гендерні переваги можуть бути пов'язані із захисною роллю естрогену [67], звичками та іншими відмінностями між чоловіком та жінкою [86]. Захворювання викликається сапрофітними грибами: Rhizopus spp. (R. oryzae, R. microspores, R. stolonifera), Mucor spp. (M. circinelloides, M. huemalis, $M$. indicus, $M$. racemosus, M. ramosissimus), Cunnighamella spp. (C. bertholletiae), Apophysamyces spp., Absidia spp., (A. Corymbifera, A. coerulea), RhizoMucor spp. (R. pussiluso, Cokeromyces spp., Sacsenaeaspp. Найчастіше виявляється Rhizopus oryzae [40]. Друга назва MM - зигомікоз. Мукормікоз $є$ загальним терміном, який позначає інфекцію, викликану різними видами грибків класу Zygomycetes. Ще один термін, використовуваний у медичних і популярних виданнях, що означає те саме захворювання, - фікомікоз.

Гриби роду Mucorales (головчата цвіль) належать до класу зигоміцети. Велика частина 3 них сапрофіти, розвиваються в грунті й, особливо, у гної травоїдних тварин. Деякі мукоровані гриби продукують антибіотики (раміцін), органічні кислоти. Їх використовують для ферментативного виробництва харчових продуктів з бобових і злаків, а також для отримання спирту із злаків. Морфологічними елементами у грибів роду Mucorales є несептований широкий міцелій білого кольору, сідії, хламідоспори. Від міцелію відходять плодоносні гіфи (спорангієносці) зі спорангієм кулястої форми, всередині якого є ендоспори спорангієспори. Схожу мікробіологічну картину виявлено у представленого пацієнта (рис. 4-8). При статевому розмноженні спостерігається утворення зигоспори, яка після періоду спокою проростає в спорангій. Існує тісна гістопатологічна схожість між ММ та аспергільозом. Мікроскопічно аспергільоз має розгалуження септи, що можна відрізнити від мукорних гіф за меншою шириною та виразними гострими кутами розщеплених гіф [45]. Міцелій гриба аспергіл (лійчаста цвіль) дещо відрізняється: септорований, широкий; колір ниток спочатку білий, згодом, залежно від виду, - зеленаво-жовтий, жовтий і чорний. Конідієносці несептовані, на кінцях мають різної форми здуття. На поверхні останніх розташовуються стеригмами, зібрані в розетку, на яких розташовуються ланцюжки кулястих конідій - екзоспори. Діагностика цих мікозів грунтується на мікробіологічному та гістологічному дослідженнях [13,35,37,38,85]. Для 
діагностики Mucorales не існує жодних тестів на виявлення циркулюючого антигена (подібного до виявлення галактоманна для інвазивного аспергільозу). Тест на 1,3 beta-D-glucan є негативним при інфекціях Mucorales та допомагає виключити інвазивний аспергільоз. Проте часто може бути комбіноване інфікування Aspergillus та Mucorales [76,93]. Дотепер не існує стандартизованого тесту полімеразноланцюгової реакції (ПЛР) у крові на ММ [84]. Тому обов'язковим для діагностики є аналіз біологічних зразків із клінічно залучених ділянок. У хворих з ГХ через глибоку тромбоцитопенію не завжди вдається отримати біопсійний матеріал 3 уражених тканин для проведення гістопатологічного дослідження та виявлення культури. Наприклад, у випадку синуситу рекомендується біопсія синуса, при ураженні легеневої тканини, якщо аналіз мазка мокротиння є негативним, - бронхо-альвеолярний лаваж або біопсія легені (ендоскопічно) [37,38]. Отриманий з біопсії матеріал повинен бути забраний делікатно, оскільки зигоміцети є крихкими, і культура може пошкодитись, а отже, існує ризик отримання негативного результату. Культивують Mucorales на глюкозному агарі Сабуро [10]. Нами верифіковано інвазивний ММ шляхом виділення патогену із змиву з бронхів та посів із зіва. За повідомленням A. Skiada та співавт. (2018), культура крові, досліджена на зигомікоз, майже завжди негативна [85]. Аналогічно ці грибки рідко присутні в цереброспінальній рідині навіть під час інфікування центральної нервової системи [85]. У представленого хворого у жодному посіві крові на гемокультуру та мікробіологічному посіві спинномозкової рідини не виявлялися грибки, зокрема роду Mucorales.

Мукормікоз - це рідкісна інфекція, яку важко верифікувати [6,8,9,11,40,68,76,84,85,93]. Кумулятивний показник захворюваності 1 року на ММ оцінюється в 4 випадках на 1000 трансплантацій стовбурових клітин та 0,6 випадку на 1000 трансплантатів органів, що становить 7\% та 2\% усіх грибкових інфекцій у цих групах відповідно. Справжня частота захворювання невідома. У 1992-1993 рр. в Сан-Франциско, штат Каліфорнія, річна частота ММ становила 1,7 випадку на 1 мільйон осіб, що дорівнює 500 випадкам на рік [61]. Вважається, що захворюваність зростає. Цей висновок був підкріплений у публікації V. Saegeman та співавт. (2010), які повідомили про збільшення числа випадків захворювання на ММ у зростаючій популяції імунодефіцитів [71]. У нещодавніх результатах дослідження у Франції щорічний показник захворюваності ММ у пацієнтів із гематологічними хворобами (ГХ) 31997 р. до 2006 р. збільшився з 0,7 до 1,2 випадку/млн осіб (+24\% на рік) [6]. Перед цим ММ часто діагностували лише при автопсії, а його частота в таких дослідженнях становила $0,4 \%-0,9 \%$ у хворих з патологією крові [9]. За результатами автопсій у багатопрофільних клініках розвинутих країн ММ виявляють у 1-5 випадках на 10000 розтинів [6]. Ріст захворюваності на MМ за останні 20 років також має зв'язок зі збільшенням частки пацієнтів, яким застосовуються імунодепресивні препарати [69]. Найчастіше цей мікоз розвивається в перші 6 місяців після трансплантації через глибоку імуносупресію. Частота ММ коливається від 0,4\% до 16\% залежно від типу трансплантації. Зокрема у реципієнтів донорського серця вона становить 0,6\% [61]. У пацієнтів із ГХ та після ТКМ ММ зустрічається у $22 \%$ випадків (відповідно у 17\% та 5\%) [69]. Аналогічно T.E. Zaoutis (2007) реєстрували у 14\% та 4\% інфікувань ММ у дітей із хворобами крові та після ТКМ відповідно [103]. Серед пацієнтів, які проходять традиційну протокольну терапію, хворі на гостру мієлоїдну лейкемію (ГМЛ) мають найвищий ризик - від 1\% до 1,9\% [36]. На відміну від цього, ММ зустрічається нечасто в інших гострих або хронічних ГХ, коли рівень захворюваності не перевищує 0,1\% [53]. Частота випадків ММ у осіб після ТКМ також нижча порівняно із хворими на ГМЛ (від 0,1\% до 0,6\%). Але найвищий рівень захворюваності на ММ спостерігався у популяції реципієнтів стовбурових клітин у випадку розвитку хвороби «трансплантант проти господаря» (graft versus-host disease (GVHD) [33].

Хвороботворні гриби мають схильність до вторгнення в кровоносну систему людини, у результаті чого відбувається емболізація 3 наступним некрозом навколишніх тканин $[2,12,13,16,17,41]$. При отриманні множинних травм і проникаючих ран, а також при вживанні води із забруднених джерел або контакті 3 грунтом посилюється можливість інфікування зигомікозом. Найчастіше зараження відбувається при контакті із забрудненими частинками пилу або повітря від кондиціонерів, колонізуючись у придаткових пазухах носа [25]. Цей гриб може зустрічатися на фруктах 
та овочах. Інфікування ним також неминуче зростає під час природних катаклізмів, наприклад, внаслідок ураганів, торнадо, цунамі або піщаної бурі. Постраждалі від природних лих люди входять до групи ризику за багатьма видами захворювань, у тому числі грибковими. Здорові люди нечасто інфікуються такими грибами. Але хвороба може розвинутися під впливом різних факторів ризику: опіки, білкове недоїдання, пневмонія або локальні дефекти слизової оболонки, такі як екстракція зубів, операції на періодонті [21,25].

Мукормікоз - це один 3 найагресивніших та смертельних інвазивних мікозів зі швидкою ангіоінвазією [12], яка зазвичай спостерігається у пацієнтів 3 імунодефіцитом [57], AA [30,31,42,59,58,94], гематологічними злоякісними новоутвореннями $[8,9,12,22,28,40$, 45,48,52,53], після трансплантації органів та ТКМ [18,33,46,60,69], глибокою нейтропенією, нирковою недостатністю, цирозом печінки [31,72], у станах із перевантаженням заліза [7,39], опіковими травмами, у випадках неконтрольованого діабету $[4,11,69]$. Унікальним фактором ризику розвитку зигомікозу є тривале застосування дефероксаміну - препарат для лікування перенавантаження організму залізом при повторних гемотрансфузіях або алюмінієм при гемодіалізі. Дефероксамін зв'язується із залізом в організмі у пацієнта і стає сидерофором для зигоміцетів [7]. C. Reed та співавт. (2006) стверджують, що дефероксамін, постачаючи залізо грибкам, посилює їхню вірулентність [66]. Наш пацієнт мав саме наступні сприятливі умови для розвитку інвазивного мікозу: постійний агранулоцитоз, комбінована ICT, перевантаження залізом організму через гемотрансфузійну залежність, застосування хелаторної терапії дефероксаміном (ексджад), проблем із рівнем глікемії у нього не було.

Зареєстровано три основні способи передачі MМ у реципієнтів трансплантатів: інгаляційно приблизно у 70\% випадках, через споживання інфікованої їі у 2\% хворих та черезшкірне введення у 13\% осіб [83]. Джерелом інфекції може бути рана у будь-якій ділянці ротової порожнини [25]. Мукормікоз ротової порожнини зазвичай спостерігається після тридцяти років життя [5]. Існують повідомлення про розвиток ММ після стоматологічних маніпуляцій у педіатричного пацієнта без імунодефіциту [25]. Наприклад, ММ верхньої щелепи швидко поширюється на придаткові пазухи носа, що призводить до некрозу патологічно ураженої кістки та перфорації [17,21,25, 41,51,65,98,99]. Ороназальна інфекція у дітей може бути небезпечною для життя. Харчування або рідини можуть затікати в пазухи або легені, призводити до розвитку синуситу, інфекції середнього вуха, пневмонії та, в кінцевому підсумку, смерті. Таким пацієнтам, як правило, проводяться хірургічні втручання iз закриттям дефектів. Нерідко використовується тимчасовий протез для запобігання відриву носа, що попереджає ороназальний рефлюкс та аспірації їею чи рідиною. Протезування допомагає при жуванні, ковтанні, мовленні та має естетичне значення [79].

У імунологічно скомпрометованих осіб ця грибкова інфекція може локалізуватися у різних місцях. Основним захистом проти i розповсюдження є достатнє число нейтрофілів [92]. Найбільш поширеною клінічною формою ММ є риноцеребральна, яка діагностується у 33-49\% пацієнтів [20,28,32,49,50,60,62,64,72, $78,81,87,98,102,103]$. Гриб після інгаляційного проникнення через ніс осідає в носових ходах та пазухах, а з етмоїдальних пазух організму може поширюватися на орбіту, екстраокулярні м'язи, офтальмологічні судини та зорові нерви 3 подальшою дисемінацією у головний мозок [50]. Така форма інфікування діагностується у понад 60\% хворих на цукровий діабет [11], оскільки гриб швидко поширюється в середовищі підвищеної глюкози та кетоацидозу [4].

У пацієнтів із ММ носоглотки часто виникають неспецифічні симптоми, такі як головний біль, лихоманка, нездужання. Класичний синдром складається зі швидко прогресуючого синуситу, періорбітального набряку та целюліту, офтальмоплегії та однобічної втрати зору [47]. У представленого хворого при появі параорбітального набряку та больових відчуттів у ділянці 1-ої гілки трійничного нерва нами в першу чергу виключався синусит. Хлопець оглядався отоларингологом. На РТГ придаткових пазух носа змін не виявлено, посів з носових пазух росту не дав.

Упродовж лікування у дитини діагностовано бактеріємію St. haemolyticus, E. coli, відзначався стоматит Str. viridans, Enterobacter aerogenes, відмінний спектр патогенів 3 різних фізіологічних середовищ. Під час перших інфекційних епізодів при мікробіологічних дослідженнях гриби не виявлялися. Враховуючи тривалість гіпертермії, відсутність ефекту від призначеного лікування, запідозрено 
інвазивний мікоз. Діагностика останнього грунтується на підтвердженні клінічної підозри, виявленні грибкових елементів мікроскопічно, із посівів вогнищ ураження, виділень із придаткових пазух, харкотиння, бронхолегеневого лаважу при мікробіологічному та гістопатологічному дослідженнях [35,37,38]. На ранніх стадіях інфікування під час клінічного огляду видима інфікована тканина може видаватися нормальною. Розповсюдження гриба прогресує через еритематозну фазу, з набряком або без нього, згодом до розвитку чорної некротизованої тканини, коли кровоносні судини тромбуються, і виникає інфаркт тканин $[61,62]$. Передуючі біль і набряки внаслідок ураження трансформуються у некроз тканин, який може призвести до патологічної перфорації [16,26,90,73]. Методи візуалізації, такі як КТ та МРТ, відіграють важливу роль в оцінці ступеня інвазії. Наш пацієнт певний час скаржився на інтенсивний біль у лівому підребер'ї, причиною якого була саме спленодіафрагмально-пульмональна фістула, зумовлена прогресуванням інвазивного ММ. Ми верифікували ММ за допомогою виявлення грибкової інфекції Mucorales у нативному мазку змиву з бронхів (рис. 4) та мікробіологічному дослідженні посіву із зіва (рис. 9). КТ-скрин у динаміці підтвердив прогресування високоагресивного мікотичного ураження в паренхімі легень, селезінки з утворенням локальних перфоративних дефектів діафрагми (рис. 1 а, б; 2 а, б; 3 а-в; 13 а-г). Саме така локалізація та зона ураження Mucorales є унікальною. Схожий клінічний випадок описано P.D. Kalogerakos та співавт. (2018) у дорослого пацієнта з лейкемією із поширенням грибка у грудній клітці й черевній порожнині. Щодо нього успішно застосовано комбіновану антимікотичну терапію та надзвичайно агресивну резекцію зони ураження - лівої латеральної торакоабдомінальної стінки, двох ребер, діафрагми зліва та селезінки [26].

Мукормікоз із ураженням легеневої тканини є небезпечним для життя захворюванням [75,101]. Пульмонологічна форма ММ реєструється за даними різних досліджень у 10-14,4\% [62,98] та у понад 25\% хворих [86]. Хоча легеневе інфікування мукором зазвичай розглядається як інвазивна паренхіматозна консолідація або кавітація, але часом може з'явитись як ендобронхіальна маса [75]. Виконана нами БС не виявила макроскопічних змін. Ізольоване ураження селезінки [80] та нирок є рідкісним проявом ММ [86]. Мукормікоз шлунково-кишкового тракту (ШКТ) у середньому виявляється у $2-11 \%[62,86,98]$, причому у $1,1 \%$ хворих можливе ураження очеревини [86]. Зустрічається ізольований зигомікоз тонкого та товстого кишечника [34] та дуже рідкісна форма ММ шлунка з розвитком перфоративної виразки $[16,34,73,90]$, яка може ускладнюватися ангіоінвазією, тромбозом та інфарктом селезінки [16,80]. Ранній діагностиці ММ із ураженням ШКТ сприяє виконання ендоскопічної діагностики із біопсією, мікробіологічне дослідження (МБД) вмісту із виявленням грибкової культури та КТ [83,90]. Оскільки згаданого пацієнта турбували виснажливі нудота, блювання та згодом біль у лівому підребер'ї, нами проводилася ЕФГДС з МБД шлункового вмісту з метою виключення мікотичного ураження верхніх відділів ШКТ. Аналіз ідентифікував $\Gamma^{-}$-збудник Enterobacter aerogen$e s$. Цей самий патоген був причиною виникнення запального інфільтрату в періанальній ділянці (рис. 11). Ураження шкіри, викликане Mucorales, діагностується, за різними даними, у 7,5\% осіб [98] та у 10-16\% випадків [82,86,88]. Дисемінований ММ діагностується у від 6-11,6\% [62,98] до 14,4\% випадків [86]. Основним фактором ризику дисемінованого ММ вважають тривалу нейтропенію, у хворих 3 підвищеним навантаженням залізом (при застосуванні дефероксаміну) $[7,39,66]$ і реципієнтів трансплантатів стовбурових кровотворних клітин [33,52,53]. Клінічні прояви при дисемінованому ММ на початковому етапі пов'язані з вогнищем первинної локалізації інфекції. Надалі, як правило, розвивається функціональна недостатність того органу, де формуються вторинні вогнища. Вогнища при дисемінованому ММ частіше локалізуються в головному мозку і легеневій тканині, значно рідше - у селезінці, серці, шкірі та інших органах. Ураження головного мозку в результаті гематогенного i/або лімфогенного поширення інфекції відрізняється від риноцеребрального ММ. У пацієнтів із дисемінованим ММ з ураженням ЦНС виникає наростаюча центральна неврологічна симптоматика i/або розвивається кома центрального генезу [4].

Незважаючи на раннє лікування, смертність пацієнтів з ММ є дуже високою - від 16\% до 100\%. За даними A. Verma та співавт. (2013), ізольований ММ з ураженням шкіри спричиняє смертність у 17\% хворих, риноцеребральна, легенева та шлунково-кишкова форма інвазії - 
у $67 \%, 83 \%$ та $100 \%$ осіб відповідно. Проте раннє медикаментозне та радикальне хірургічне втручання обмежують поширення грибкової інфекції у життєво важливі органи та сприяють виживанню пацієнта на 80\% [99]. У дослідженні H.S. Yamin зі співавт. (2017) при ураженні легень мукором загальне виживання становило $52,1 \%$, майже третина $(31,2 \%)$ пацієнтів - при застосуванні лише медикаментозної терапії, $100 \%$ залишилися живими після проведення комбінованого медикаментозного та хірургічного лікування. $€$ повідомлення про суттєво вищу смертністю у трансплантованих хворих: при ММ із легеневою інфекцією у 42,2\% реципієнтів, у 76\% із дисемінованим ураженням та 55,6\% хворих з нирковою інфекцією. Найнижчим відзначено виживання (42,85\%) з-поміж хворих на злоякісні новоутворення [101].

Діагностувати ММ є складним завданням, і лікування слід розпочати якнайшвидше, щоб зменшити ризик смерті. Згідно з рекомендаціями ECIL [93], для терапії MM рекомендується поєднання антимікотичної терапії та хірургічного видалення осередку ураження, а також контроль фонових станів (категорія доказовості рекомендацій (КДР) - AІІ). Так, при неконтрольованому діабеті необхідно провести швидку корекцію метаболічних змін. Рекомендується за можливості припинити або зменшити дози кортикостероїдів, імуносупресантів, дефероксаміну. Препаратом вибору у лікуванні MМ є амофтерицин В (AmB). Дезоксихолат амфіторицину B (d-AmB) має значну токсичність і замінений ліпідними формами $\mathrm{AmB}$, які включають ліпосомальний $\mathrm{AmB}$ ( $\mathrm{L}-\mathrm{AmB})$, ліпідний комплекс $\mathrm{AmB}$ (ABLC) та колоїдну дисперсію AmB (ABCD). Ліпідні форми AmB менш нефротоксичні, ніж d-AmB, що дозволяе тривале введення та більші добові дози із меншою нефротоксичністю. Відповідно до сучасних рекомендацій, препаратами першої лінії для лікування MM є ABLC та L-AmB (КДР BII) [84,93]. Дуже важливо розпочати терапію якнайшвидше. G. Chamilos та співавт. (2006) стверджують, що ініціаціальне лікування у перші п'ять днів після діагностики ММ поліпшує виживання порівняно з початком полієнової терапії через 6 і більше днів після верифікації процесу (83\% проти 49\% відповідно) [9]. Після досягнення клінічного ефекту, як елемент другої лінії лікування, продовжують давати позаконазол 800 мг/добу (КДР - BII). За неефективності стартової терапії можливе застосування комбінації ліпідних препаратів амфотерицину В і ехінокандинів. Монотерапія позаконазолом (ноксофіл) не рекомендується як первинна терапія ММ (КДР - CIII). Проте клінічні дані демонструють, що позаконазол можна застосовувати для пацієнтів із резистентними формами ММ або із непереносимістю AmB та тим пацієнтам, які потребують тривалої підтримуючої терапії (КДР - ВII) $[19,93,97]$. При прийомі позаконазолу найпоширенішими побічними ефектами є нудота, блювання, запор, головний біль, сухість у роті, сонливість, запаморочення, також він може бути причиною первинної недостатності надниркових залоз [48].

Ітраконазол має змінну активність in vitro з відмінностями між родами та всередині роду, найкраща активність якої повідомляється до Lichtheimia spp. [3,15]. У експериментальній моделі ітраконазол знижує смертність імунокомпетентних мишей, інфікованих Lichtheimia corymbifera та Apophysomyces elegans, але не у тварин, інфікованих мікроспорами Rhizopus [15]. Незважаючи на повідомлення про рідкісні випадки, даних рандомізованих досліджень недостатньо для підтримки його використання як монотерапії при ММ у клінічній практиці у людей. Такі препарати, як каспуфунгін, анідулафунгін і мікафунгін, недієві у випадку інфікування Mucorales [3]. Не знайдено також активності проти агентів ММ флуцитозином [3]. Клінічних даних стосовно монотерапії тербінафіну в пацієнтів з ММ не існує [15].

Тривалість протигрибкового лікування повинна визначатися індивідуально, але терапія зазвичай триває щонайменше 6-8 тижнів.

Флуконазол і вориконазол не мають суттевої активності проти грибів роду Mucorales in vitro та в експериментальних моделях [3]. Деякі клінічні дані свідчать, що застосування воріконазолу для профілактики або емпіричної терапії спричиняє збільшення частоти ММ [46,96]. Чи справді воріконазол суттєво впливає на захворюваність на ММ або інші опортуністичні патогени, чутливі до воріконазолу, подовжуючи виживання пацієнтів, залишається контроверсійним питанням. У нашого пацієнта виявлена максимальна чутливість Mucorales не лише до амфотеріцину В, але й до воріконазолу (рис. 10). Тому вважаємо за доцільне повідомити про цей факт із власного спостереження. Можливо, є якась відмінність серед роду Мисоrales у чутливості до даного препарату. Дитина отримувала інтенсивне протигрибкове лікування - ітраконазол (орунгал), мікафунгін (міка- 
мін), каспофунгін (кансідаз), АmB (амфоліп ліпідасоційовану форму амфотерицину $\mathrm{B}$, містить протигрибкову сполуку амфотерицин В у комплексі з фосфоліпідами) самостійно та в комбінації із позаноказолом, воріконазолом, у поєднанні з антибіотиками широкого спектра дії, довенним людським імуноглобуліном, гранулоцитарними факторами росту. Останнім протигрибковим препаратом був воріконазол у дозі 7 мг/кг двічі на добу. Призначена терапія була частково ефективною, після виявлених змін на останніх РТГ та КТ, оскільки зменшились епізоди блювання, гіпертермії до 2-х разів на добу та висота гарячки, гідроторакс, гепатолієнальний синдром, ознаки загальної інтоксикації. У динаміці: запальний інфільтрат з ураженням періанальної ділянки та правої сідниці регресував, норицевий хід загоївся. Утримувалася рефрактерна форма важкої набутої АА до протокольної ICT, гемотрансфузійна залежність. Пацієнт у компенсованому та транспортабельному стані залишив наш стаціонар та продовжив лікування за кордоном.

Враховуючи особливість ангіоінвазивності ММ, що призводить до утворення поширеного тромбозу, інфаркту та некрозу тканин, які можуть погіршити проникнення протигрибкових медикаментів до місця інфікування, 3 метою зменшення маси заражених тканин і запобігання розширенню ММ на сусідні тканини, є доцільним своєчасне висічення, якщо це можливо, усієї девіталізованої тканини. Хірургічне видалення вогнищ ураження відіграє дуже важливу роль в одужанні та виживанні хворих (КДР - АІІ). Щодо нашого хворого розглядалося питання хірургічного лікування, яке мало б полягати щонайменше у лобектомії лівої легені, з висіченням діафрагми та спленктомії. Консилярно прийнято рішення продовжити консервативне багатокомпонентне лікування, оскільки таке інвазивно-радикальне хірургічне втручання має високий ризик для життя пацієнта.

Існують повідомлення про ряд додаткових методів лікування, які покращують прогноз перебігу ММ. Як потенційну стратегію лікування для покращення надходження ліків до інфікованих та ішемічних тканин запропоновано зрошування AmB [102]. Автори вважають, що на ранніх стадіях інфікування цей метод може зменшити необхідність хірургічних втручань [102]. S.R. Seiff та співавт. повідомляють, що лише один із семи пацієнтів, які отримували стандартну терапію та місцевий
AmB, потребував орбітальної екстенціації [77]. Через недостатню кількість подібних наукових досліджень не можна остаточно стверджувати, що зрошування $\mathrm{AmB}$ мають вплив на захворюваність та смертність від ММ. Розглядається допоміжна терапія гамма-інтерфероном, гранулоцитарними факторами росту при резистентному інвазивному ММ, хоча дані обмежені $[1,70]$. На думку B.V. John зі співавт. (2005), гіпербарична оксигенація може бути корисною, оскільки обмежує вторгнення грибкових тканин за рахунок зниження гіпоксії та ацидозу в ішемічних тканинах, що $€$ результатом ангіоінвазивної хвороби [24]. Однак існують обмежені дослідження для підтвердження iii ефективності та зменшення летальності. Із зазначених допоміжних елементів лікування ми застосовували гранулоцитарні фактори росту. Інші вищезгадані додаткові терапевтичні методики нами не застосовувалися.

Таким чином, описаний клінічний випадок демонструє, що інфекційні ускладнення розвиваються як на початку, так і в процесі ICT. Ризик-факторами ранніх інфекційних епізодів у представленого хворого було застосування глюкокортикоїдних гормонів на ранніх етапах лікування до клінічних проявів АА, а також тривалий агранулоцитоз. Для розвитку інвазивного ММ мали вплив комбінована ICT, стан перевантаження залізом організму через гемотрансфузійну залежність, застосування хелаторної терапії дефероксаміном. Вкрай важливим $є$ активне проведення діагностичних заходів, спрямованих на пошук вогнища інфекції та ідентифікацію збудників. Патогенетична терапія дає змогу не лише успішно вилікувати інфекційний процес, а й своєчасно проводити всі етапи комплексної ICT, що дозволяє значно підвищити виживання хворих на АА.

\section{Висновки}

Інфекційні ускладнення у хворих на АA $є$ однією з найсерйозніших проблем на різних етапах перебігу хвороби. Етіологія інфекцій у даної категорії хворих досить різноманітна, при цьому відзначається збільшення частки ускладнень, викликаних різними збудниками грамнегативними, грампозитивними й іншими патогенами, що рідко зустрічаються, зокрема грибами, для лікування яких необхідна прецизійна діагностика та терапія. У зв'язку з цим вивчення частоти і характеру інфекційних ускладнень, а також аналіз мікрофлори, що викликає ці ускладнення в умовах сучасної 
програмної ICT, є актуальним. Мінливий спектр патогенів та зростання іхньої антибіотикорезистентності вимагають розробки чітких рекомендацій, необхідних для ефективної реалізації сучасних протоколів комбінованої ICT. Наш випадок вимагав широкого міждисциплінарного підходу із залученням медичних працівників різних спеціальностей. Мукормікоз - це рідкісна, агресивна, швидко прогресуюча та небезпечна для життя грибкова інфекція, яка потребує чітких та оптимальних дій. $€$ багато невирішених питань щодо епідеміології, діагностики та терапії ММ. Незважаючи на важливі досягнення, все ще існує потреба в кращих діагностичних тестах для верифікації ММ та якнайшвидшого початку відповідного лікування хворих. На основі існуючих даних ECIL виробила рекомендації для допомоги клініцистам. Проте існують певні прогалини в знаннях щодо керування цим інфекційним процесом, включаючи комбіновану терапію, застосування додаткових методів лікування та оцінку відповіді. Існує необхідність у створенні в Україні медичної студії рандомізованих контрольованих досліджень із вивчення інвазивних мікозів.

Автори заявляють про відсутність конфлікту інтересів.

\section{ЛITEPATУРA}

1. Abzug MJ, Walsh TJ. (2004). Interferon- $\gamma$ and colony-stimulating factors as adjuvant therapy for refractory fungal infections in children. Pediatr Infect Dis J. 23:769-773.

2. Al-Jabri S, Al-Abri M, Al-Hinai A, Al-Azri F. (2013). Bilateral Ocular Ischaemic Syndrome-Rare Complication of Rhinocerebral Mucormycosis in an Omani Patient: Case report and literature review. Sultan Qaboos Univ Med J. 13(1):137-142.

3. Almyroudis NG, Sutton DA, Fothergill AW, Rinaldi MG, Kusne S. (2007). In vitro susceptibilities of 217 clinical isolates of zygomycetes to conventional and new antifungal agents. Antimicrob Agents Chemother. 51(7):2587-2590.

4. Anand VK, Alemar G, Griswold JA Jr. (1992). Intracranial complications of mucormycosis: An experimental model and clinical review. Laryngoscope. 102:656-662.

5. Aras MH, Kara MI, Erkilic S, Ay S. (2012). Mandibular mucormycosis in immunocompromised patients: report of 2 cases and review of the literature. J Oral Maxillofac Surg. 70:1362-1368.

6. Bitar D, Van Cauteren D, Lanternier F, Dannaoui E, Che D, Dromer F. (2009). Increasing incidence of zygomycosis (mucormycosis), France, 1997-2006. Emerg Infect Dis. 15:1395-1401.

7. Boelaert R, de Locht M, Van Cutsem J, Kerrels V, Cantinieaux B, Verdonck A. (1993). Mucormycosis during deferoxamine therapy is a siderophore-mediated infection. In vitro and in vivo animal studies. J Clin Investig. 91(5):1979-1986.

8. Bonifaz A, Tirado-Sanchez A, Calderon L, Romero-Cabello R, Kassack J, Ponce RM, Mena C, Stchigel A, Cano J, Guarro J. (2014). Mucormycosis in children: a study of 22 cases in a Mexican hospital. Mycoses. 57(3):79-84.

9. Chamilos G, Luna M, Lewis RE, Bodey GP, Chemaly R, Tarrand JJ et al. (2006). Invasive fungal infections in patients with hematologic malignancies in a tertiary care cancer center: an autopsy study over a 15-year period (1989-2003). Haematologica. 91(7):986-989.

10. Chayakulkeeree M, Ghannoum MA, Perfect JR. (2006). Zygomycosis: The re-emerging fungal infection. Eur $\mathrm{J}$ Clin Microbiol Infect Dis. 25:215-229.

11. Chow V, Khan S, Balogun A, Mitchell D, Muhlschlegel FA. (2014). Invasive rhino-orbito-cerebral mucormycosis in a diabetic patient - the need for prompttreatment. Med Mycol Case Rep. 8:5-9.

12. Cofre F, Villarroel M, Castellon L, Santolaya ME. (2015). Successful treatment of a persistent rhino-cerebral mucormycosis in a pediatric patient with a debut of acute lymphoblastic leukemia. Rev Chilena Infectol. 32(4):458-463.

13. Cornely OA, Arikan-Akdagli S, Dannaoui E, Groll AH, Lagrou K, Chakrabarti A, Lanternier F, Pagano L, Skiada A et al. (2014). ESCMID

and ECMM joint clinical guidelines for the diagnosis and management of mucormycosis 2013. Clin Microbiol Infect. 20(3):5-26.

14. Dai Y, Walker JW, Halloush RA, Khasawneh FA. (2013). Mucormycosis in two community hospitals and the role of infectious disease consultation: a case series. Int J Gen Med. 6:833-838.

15. Dannaoui E, Mouton JW, Meis JF, Verweij PE. (2002). Efficacy of antifungal therapy in a non-neutropenic murine model of zygomycosis. Antimicrob Agents Chemother. 46(6):1953-1959.

16. Enani MA, Alharthi BN, Dewanjee N, Bhat NA, Fagih M. (2014). Spontaneous Gastric Ulcer Perforation and Acute Spleen Infarction Caused by Invasive Gastric and Splenic Mucormycosis. J Glob Infect Dis. 6(3):122-124.

17. Garg R, Gupta VV, Ashok L. (2011). Rhinomaxillary mucormycosis: A palatal ulcer. Contemp Clin Dent. 2(2):119-123.

18. Geramizadeh B, Kazemi K, Shamsaifar AR, Bahraini A, Nikeghbalian S, Malekhosseini SA. (2012). Isolated renal mucormycosis after liver transplantation:an unusual case report. Iran Red Crescent Med J. 14(7):447-450.

19. Greenberg RN, Mullane K, van Burik JA, Raad I, Abzug MJ, Anstead G et al. (2006). Posaconazole as salvage therapy for zygomycosis. Antimicrob Agents Chemother. 50(1):126-133.

20. Gutierrez-Delgado EM, Trevino-Gonzalez JL, Montemayor-Alatorre A, Cecenas-Falcon LA, Ruiz-Holguin E, Andrade-Vazquez CJ, Lara-Medrano R, Ramos-Jimenez J. (2016). Chronic rhino-orbito-cerebral mucormycosis: A case report and review of the literature. Ann Med Surg (Lond). 6:87-91.

21. Huang JS, Kok SH, Lee JJ, Hsu WY, Chiang CP, Kuo YS. (2005). Extensive maxillary sequestration resulting from mucormycosis. $\mathrm{Br} \mathrm{J}$ Oral Maxillofac Surg. 43:532-534.

22. Hughes WT, Armstrong D, Bodey GP et al. (2002). guidelines for the use of antimicrobial agents in neutropenic patients with cancer. Clin Infect Dis. 34:730-751.

23. Inglesfield S, Jasiulewicz A, Hopwood M, Tyrrell J, Youlden G, Mazon-Moya M, Millington OR, Mostowy S, Jabbari S, Voelz K. (2018). Robust phagocyte recruitment controls the opportunistic fungal pathogen mucor circinelloides in innate granulomas in vivo. MBio. 9(2):e02010-17.

24. John BV, Chamilos G, Kontoyiannis DP. (2005). Hyperbaric oxygenas an adjunctive treatment for zygomycosis. Clin Microbiol Infect. 11:515-517.

25. Kalaskar RR, Kalaskar AR, Ganvir S. (2016). Oral mucormycosis in an 18-month-old child: a rare case report with a literature review. J Korean Assoc Oral Maxillofac Surg. 42(2):105-110.

26. Kalogerakos PD, Kiparakis M, Pavlaki K, Pontikoglou C, Lazopoulos G, Chalkiadakis G. (2018). Thoracoabdominal resection 
of mucormycosis lesions in a leukemic patient. Ann Thorac Surg. 106(5):e239-e241.

27. Kaneko Y, Oinuma KI, Terachi T, Arimura Y, Niki M, Yamada K, Kakeya H, Mizutani T. (2018). Successful treatment of intestinal mycosis caused by a simultaneous infection with lichtheimia ramosa and aspergillus calidoustus. Intern Med. 57(16):2421-2424.

28. Keklik M, Yildirim A, Ozturk F, Ileri I, Akyol G, Cetin M, Eser B. (2015). Rhinocerebral mucormycosis in a patient with acute promyelocytic leukemia. Turk J Haematol. 32(1):96-97.

29. Kermani W, Bouttay R, Belcadhi M, Zaghouani H, Ben Ali M, Abdelkefi M. (2016). ENT mucormycosis. Report of 4 cases. Eur Ann Otorhinolaryngol Head Neck Dis. 133(2):83-86.

30. Killick SB, Marsh JC. (2000). Aplastic anaemia: management. Blood Rev. 14:157-171.

31. Kojima S, Nakao S, Young N, Bacigalupo A, Gerard G, Hirano N, MaciejewskiJ, Deeg J, Marsh J, Zhang FK, Lee JW, Ozawa K. (2011). The Third Consensus Conference on the treatment of aplastic anemia. Int J Hematol. 93(6):832-837.

32. Kolekar JS. (2015). Rhinocerebral mucormycosis: a retrospective study. Indian J Otolaryngol Head Neck Surg. 67(1):93-96.

33. Kontoyiannis DP, Marr KA, Park BJ, Alexander BD, Anaissie EJ, Walsh TJ et al. (2010). Prospective surveillance for invasive fungal infections in hematopoietic stem cell transplant recipients, 2001-2006: Overview of the Transplant-associated infection Surveillance Network (TRANSNET) database. Clin Infect Dis. 50(8):1091-1100.

34. Kulkarni RV, Thakur SS. (2015). Invasive Gastric Mucormycosis a Case Report. Indian J Surg. 77(1):87-89.

35. Lackner M, Caramalho R, Lass-Florl C. (2014). Laboratory diagnosis of mucormycosis: current status and future perspectives. Future Microbiol. 9(5):683-695.

36. Lanternier F, Dannaoui E, Morizot G, Elie C, Garcia-Hermoso D, Huerre $M$, et al. (2012). A global analysis of mucormycosis in France: the RetroZygo study (2005-2007). Clin Infect Dis. 54(1):35-43.

37. Lass-Florl C, Resch G, Nachbaur D, Mayr A, Gastl G, Auberger J et al. (2007). The value of computed tomography-guided percutaneous lung biopsy for diagnosis of invasive fungal infection in immunocompromised patients. Clin Infect Dis. 45(7):e101-104.

38. Lass-Florl C. (2009). Zygomycosis: conventional laboratory diagnosis. Clin Microbiol Infect. 15(5):60-65.

39. Lee JW, Yoon SS, Shen ZX, Ganser A, Hsu HC, Habr D et al. (2010, Oct. 7). Iron chelation therapy with deferasirox in patients with aplastic anemia: a subgroup analysis of 116 patients from the EPIC trial. Blood. 116(14):2448-54.

40. Lehrer RI, Howard DH, Sypherd PS, Edwards JE, Segal GP, Winston DJ. (1980). Mucormycosis. Ann Intern Med. 93:93-108.

41. Leitner C, Hoffmann J, Zerfowski M, Reinert S. (2003). Mucormycosis: Necrotizing soft tissue lesion of the face. J Oral Maxillofac Surg. 61:1354-1358.

42. Ljungman P. (2000). Supportive treatment of patient with severe aplastic anemia. In: Schrezenmeier H, Bacigalupo A, editors. Aplastic anemia: pathophysiology and treatment. Cambridge, UK: Cambridge University Press:137.

43. Mahmud A, Lee R, Munfus-McCray D, Kwiatkowski $N$, Subramanian A, Neofytos D, Carroll K, Zhang SX. (2012). Actinomucor elegans as an emerging cause of Mucormycosis. J Clin Microbiol. 50(3):1092-1095.

44. Mahomed S, Basanth S, Mlisana K. (2015). The successful use of amphotericin $B$ followed by oral posaconazole in a rare case of invasive fungal sinusitis caused by co-infection with mucormycosis and aspergillus. IDCases. 2(4):116-117.

45. Manjunatha BS, Das N, Sutariya RV, Ahmed T. (2012). Mucormycosis of the hard palate masquerading as carcinoma. Clin Pract. 2:e28.
46. Marty FM, Cosimi LA, Baden LR. (2004). Breakthrough zygomycosis after voriconazole treatment in recipients of hematopoietic stem-cell transplants. N Engl J Med. 350(9):950-952.

47. Merkler AE, Duggal I, Kaunzner U, Maciel CB, Miller AM, Scognamiglio T, Dinkin MJ. (2016). Rapidly progressive bilateral optic nerve and retinal infarctions due to rhinocerebral mucormycosis and pseudoephedrine use. Neurol Clin Pract. 6(6):549-552.

48. Miller A, Brooks LK, Poola-Kella S, Malek R. (2018). PosaconazoleInduced Adrenal Insufficiency in a Case of Chronic Myelomonocytic Leukemia. Case Reports in Endocrinology. 2018. Article ID 2170484:5.

49. Mohammadi R, Nazeri M, Sayedayn SM, Ehteram H. (2014). A successful treatment of rhinocerebral mucormycosis due to Rhizopus oryzae. J Res Med Sci. 19(1):72-74.

50. Mulki R, Masab M, Eiger G, Perloff S. (2016). Lethargy and vision loss: successful management of rhinocerebral mucormycosis. BMJ Case Rep. 2016.

51. Nilesh K, Vande AV. (2018). Mucormycosis of maxilla following tooth extraction in immunocompetent patients: Reports and review. J Clin Exp Dent. 10(3):e300-e305.

52. Pagano L, Caira M, Candoni A, Offidani M, Franchi L, Martino B et al. (2006). The epidemiology of fungal infections in patients with hematologic malignancies: the SEIFEM-2004 study. Haematologica. 91(8):1068-1075.

53. Pagano L, Girmenia C, Mele L, Ricci P, Tosti ME, Nosari A, Buelli M, Picardi M, Allione B, Corvatta L, D'Antonio D, Montillo M, Melillo L, Chierichini A, Cenacchi A, Tonso A, Cudillo L, Candoni A, Savignano C, Bonini A, Martino P, Del Favero A; GIMEMA Infection Program; Gruppo Italiano Malattie Ematologiche dell'Adulto. (2001). Infections caused by filamentous fungi in patients with hematologic malignancies. A report of 391 cases by GIMEMA Infection Program. Haematologica. 86(8):862-870.

54. Palejwala SK, Zangeneh TT, Goldstein SA, Lemole GM. (2016). An aggressive multidisciplinary approach reduces mortality in rhinocerebral mucormycosis. Surg Neurol Int.7:61.

55. Paltauf A. (1885). Mycosis mucorina. Virchows Arch Pathol Anat. 102:543-564.

56. Pana ZD, Seidel D, Skiada A, Groll AH, Petrikkos G, Cornely OA, Roilides

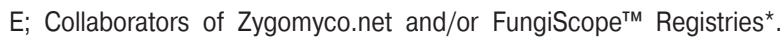
(2016). Invasive mucormycosis in children: an epidemiologic study in European and non-European countries based on two registries. BMC Infect Dis.16(1):667.

57. Patel A, Bishburg E, Nagarakanti S. (2014). Mucormycosis in an HIV-infected renal transplant patient: A case report and review of the literature. Am J Case Rep. 15:74-78.

58. Pawelec K, Salamonowicz M, Panasiuk A, Matysiak M, Demkow U. (2013). Respiratory and systemic infections in children with severe aplastic anemia on immunosuppressive therapy. Adv Exp Med Biol. 788:417-425

59. Pawelec K, Salamonowicz M, Plichta P, Matysiak M. (2010). Powiklania leczenia immunoablacyjnego u pacjentki z anemia aplastyczna. Nowa Pediatria. 14(4):140-144.

60. Pedemonte-Sarrias G, Gras-Cabrerizo JR, Rodriguez-Alvarez F, Montserrat-Gili JR. (2015). Rhinocerebral mucormycosis in a 5-month heart transplant recipient. J Oral Maxillofac Pathol. 19(3):375-378.

61. Petrikkos G, Skiada A, Lortholary O, Roilides E, Walsh TJ, Kontoyiannis DP. (2012). Epidemiology and clinical manifestations of mucormycosis. Clin Infect Dis. 54(1):S23-S34.

62. Prabhu RM, Patel R. (2004). Mucormycosis and entomophthoramycosis: A review of the clinical manifestations, diagnosis and treatment. Clin Microbiol Infect. 10(1):31-47.

63. Quarello P, Saracco P, Giacchino M, Caselli D, Caviglia I, Longoni D, Varotto S, Rana I, Amendola A, Misuraca A, Licciardello M, Paolucci P, 
Ladogana S, Rivetti E, Dufour C, Castagnola E. (2012). Epidemiology of infections in children with acquired aplastic anaemia: a retrospective multicenter study in Italy. Eur J Haematol. 88(6):526-534.

64. Rahman A, Akter K, Hossain S, Rashid HU. (2013). Rhino-orbital mucourmycosis in a non-immunocompromised patient. BMJ Case Rep. $2013(1): 1-4$

65. Rai S, Misra D, Misra A, Jain A, Jain P, Dhawan A. (2018). Palatal Mucormycosis Masquerading as Bacterial and Fungal Osteomyelitis: A Rare Case Report. Contemp Clin Dent. 9(2):309-313.

66. Reed C, Ibrahim A, Edwards JE Jr. (2006). Deferasirox, an iron-chelating agent, as salvage therapy for rhinocerebral mucormycosis. Antimicrob Agents Chemother. 50(11):3968-3969.

67. Restrepo A, Salazar ME, Cano LE, Stover EP, Feldman D, Stevens DA. (1984). Estrogens inhibit mycelium-to-yeast transformation in the fungus Paracoccidioides brasiliensis: implications for resistance of females to paracoccidioidomycosis. Infect Immun. 46(2):346-353.

68. Riley TT, Muzny CA, Swiatlo E, Legendre DP. (2016). Breaking the Mold: A Review of Mucormycosis and Current Pharmacological Treatment Options. Ann Pharmacother. 50(9):747-457.

69. Roden MM, Zaoutis TE, Buchanan WL, Knudsen TA, Sarkisova TA, Schaufele RL et al. (2005). Epidemiology and outcome of zygomycosis: A review of 929 reported cases. Clin Infect Dis. 41: 634-653.

70. Roilides E, Farmaki E. (2001). Granulocyte colony-stimulating factor and other cytokines in antifungal therapy. Clin Microbiol Infect. 7:62-67.

71. Saegeman V, Maertens J, Meersseman W, Spriet I, Verbeken E, Lagrou K. (2010). Increasing incidence of mucormycosis in University Hospital, Belgium. Emerg Infect Dis. 16(9):1456-1458.

72. Sahota R, Gambhir R, Anand S, Dixit A. (2017). Rhinocerebral Mucormycosis: Report of a Rare Case. Ethiop J Health Sci. 27(1): 85-90.

73. Sanchez Velazquez P, Pera M, Gimeno J, Zapatero A, Nolla J, Pera M. (2017). Mucormycosis: an unusual cause of gastric perforation and severe bleeding in immunocompetent patients. Rev Esp Enferm Dig. 109(3):223-225.

74. Sasannejad P, Ghabeli-Juibary A, Aminzadeh S, Olfati N. (2015). Cerebellar infarction and aneurysmal subarachnoid hemorrhage: An unusual presentation and rare complications of rhinocerebral mucormycosis. Iran J Neurol. 14(4):222-224.

75. Sayan M, Arpag H, Tokur M, Bahar AY. (2018). Pulmonary mucormycosis mimicking an endobronchial mass. Asian Cardiovasc Thorac Ann. 26(3):242-244.

76. Seidel D, Duran Graeff LA, Vehreschild MJGT, Wisplinghoff H, Ziegler M, Vehreschild JJ, Liss B, Hamprecht A, Kohler P, Racil Z, Klimko N, Sheppard DC, Herbrecht R, Chowdhary A, Cornely OA, FungiScope Group. FungiScope $^{\mathrm{TM}}$. (2017). Global Emerging Fungal Infection Registry. Mycoses. 60(8):508-516.

77. Seiff SR, Choo PH, Carter SR. (1999). Role of local amphotericin B therapy for sino-orbital fungal infections. Ophthal Plast Reconstr Surg. 15:28-31.

78. Sellami M, Mnejja M. (2017). Rhinocerebral mucormycosis: a rare infection. Pan Afr Med J. 26:143.

79. Shah RJ, Katyayan MK, Katyayan PA, Chauhan V. (2014). Prosthetic rehabilitation of acquired maxillary defects secondary to mucormycosis: clinical cases. J Contemp Dent Pract. 15:242-249.

80. Sharma SK, Balasubramanian P, Radotra B, Singhal M. (2018). Isolated splenic mucormycosis in a case of aplastic anaemia; BMJ Case Rep. 2018.

81. Shi GG, Shi L, Zhang ZY, Wan YZ, Li B, Yu L, Zhang EP, Ju HS, He MQ, $\mathrm{Ji} \mathrm{HZ}$. (2016). Clinical analyses of the diagnosis and treatment of invasive fungal rhinosinusitis: report of 14 cases. Zhonghua Er Bi Yan Hou Tou Jing Wai Ke Za Zhi. 51(8):561-567.
82. Shukla A, Shrivastava N, Singh CA, Nayak B. (2016). Percutaneous Management of Systemic Fungal Infection Presenting As Bilateral Renal Fungal Ball. J Endourol Case Rep. 2(1):152-154.

83. Singh N, Gayowski T, Singh J, Yu VL. (1995). Invasive gastrointestinal zygomycosis in a liver transplant recipient: Case report and review of zygomycosis in solid-organ transplant recipients. Clin Infect Dis. 20:617-620.

84. Skiada A, Lanternier F, Groll AH, Pagano L, Zimmerli S, Herbrecht R, Lortholary O, Petrikkos GL; European Conference on Infections in Leukemia. (2013). Diagnosis and treatment of mucormycosis in patients with hematological malignancies: guidelines from the 3rd European Conference on Infections in Leukemia (ECIL 3). Haematologica. 98(4):492-504.

85. Skiada A, Lass-Floerl C, Klimko N, Ibrahim A, Roilides E, Petrikkos G. (2018). Challenges in the diagnosis and treatment of mucor mycosis. Med Mycol. 56(11):93-101.

86. Song Y, Qiao J, Giovanni G, Liu G, Yang H, Wu J, Chen J. (2017). Mucormycosis in renal transplant recipients: review of 174 reported cases. BMC Infect Dis. 17(1):283.

87. Sravani T, Uppin SG, Uppin MS, Sundaram C. (2014). Rhinocerebral mucormycosis: Pathology revisited with emphasis on perineural spread. Neurol India. 62(4):383-386.

88. Stein MK, Karri S, Reynolds J, Owsley J, Wise A, Martin MG, Zare F. (2018). Cutaneous Mucormycosis Following a Bullous Pemphigoid Flare in a Chronic Lymphocytic Leukemia Patient on Ibrutinib. World J Oncol. 9(2):62-65.

89. Tacke D, Koehler P, Markiefka B, Cornely OA. (2014). Our 2014 approach to mucormycosis. Mycoses. 57(9):519-524.

90. Termos S, Othman F, Alali M, Al Bader BMS, Alkhadher T, Hassanaiah WF, Taqi A, Sapkal A. (2018). Total Gastric Necrosis Due to Mucormycosis: A Rare Case of Gastric Perforation. Am J Case Rep. 19:527-533.

91. Thomas S, Singh VD, Vaithilingam Y, Thayil SC, Kothari R. (2012). Rhinocerebral mucormycosis - a case report. Oral Maxillofac Surg. 16(2):233-236.

92. Tichelli A, Schrezenmeier H, Socie G, Marsh J, Bacigalupo A, Daehrsen $U$ et al. (2009). Use of G-CSF in patients with severe aplastic anemia treatment with ATG and cyclosporine increases neutrophils and decreases infection rates and hospital days but dose not improve long-term outcome: Results of a prospective randomizes clinical trial of the EBMT. Blood. 114:205a.

93. Tissot F, Agrawal S, Pagano L et al. (2017). ECIL-6 guidelines for the treatment of invasive candidiasis, aspergillosis and mucormycosis in leukemia and hematopoietic stem cell transplant patients. Haematologica. 102(3):433-444.

94. Torres HA, Bodey GP, Rolston KV, Kantarjian HM, Raad II, Kontoyiannis DP. (2003). Infections in patients with aplastic anemia. Cancer. 98:86-93.

95. Torres HA, Bodey GP, Rolston KV, Kantarjian HM, Raad II, Kontoyiannis DP. (2003). Infections in patients with aplastic anemia: experience at a tertiary care cancer center. Cancer. 98(1):86-93.

96. Trifilio S, Singhal S, Williams S, Frankfurt O, Gordon L, Evens A et al. (2007). Breakthrough fungal infections after allogeneic hematopoietic stem cell transplantation in patients on prophylactic voriconazole. Bone Marrow Transplant. 40(5):451-456.

97. van Burik JA, Hare RS, Solomon HF, Corrado ML, Kontoyiannis DP. (2006). Posaconazole is effective as salvage therapy in zygomycosis: a retrospective summary of 91 cases. Clin Infect Dis. 42(7):e61-e65.

98. Venkatesh D, Dandagi S, Chandrappa PR, Hema KN. (2018). Mucormycosis in immunocompetent patient resulting in extensive maxillary sequestration. J Oral Maxillofac Pathol. 22(1):S112-S116. 
99. Verma A, Singh V, Jindal N, Yadav S. (2013). Necrosis of maxilla, nasal, and frontal bone secondary to extensive rhino-cerebral mucormycosis. Natl J Maxillofac Surg. 4:249-251.

100.Wang Y, Zhu M, Bao Y, Li L, Zhu L, Li F, Xu J, Liang J. (2018). Cutaneous mucormycosis caused by Rhizopus microsporus in an immunocompetent patient: A case report and review of literature. Medicine (Baltimore). 97(25):e11141.

101.Yamin HS, Alastal AY, Bakri I. (2017). Pulmonary Mucormycosis Over 130 Years: A Case Report and Literature Review. Turk Thorac J. 18(1):1-5.
102.Yohai RA, Bullock JD, Aziz AA et al. (1994). Survival factors in rhino-orbital-cerebral mucormycosis. Surv Ophthalmol. $39: 3-22$.

103.Zaoutis TE, Roilides E, Chiou CC, Buchanan WL, Knudsen TA, Sarkisova TA et al. (2007). Zygomycosis in children: a systematic review and analysis of reported cases. Pediatr Infect Dis J. 26(8):723-727.

104.Zeka AN, Tasbakan M, Pullukcu H, Sipahi OR, Yamazhan T, Arda B. (2013). Evaluation of zygomycosis cases by pooled analysis method reported from Turkey. Mikrobiyol Bul. 47(4):708-716.

\section{Сведения об авторах:}

Дорош Ольга Игоревна - к.мед.н., врач-гематолог детский отделения гематологии и интенсивной химиотерапии и отделения консультативной поликлиники Коммунального некоммерческого преприятия Львовского областного совета «Западноукраинский специализированный детский медицинский центр». Адрес: г. Львов, ул. Днестровская, 27.

Адрес. Г. Львов, ул. Днестровская, 27.

«имьяк Лариса Степановна - врач-бактериолог, зав. баклабораторией Коммунального некоммерческого препр

Кушарская Ольга Владимировна - врач-бактериолог бактериологической лаборатории Коммунального некоммерческого преприятия Львовского областного совета «Западноукраинский специализированный детский медицинский центр». Адрес: г. Львов, ул. Днестровская, 27.

Василив Ирина Любомировна - врач-рентгенолог отделения лучевой диагностики Коммунального некоммерческого преприятия Львовского областного совета «Западноукраинский специализированный детский медицинский центр", врач-рентгенолог отделения радиологии Медицинского центра «ОМЕГА».

Адрес: г. Киев, ул. Максимовича, 10

Мелько Ирина Петровна - врач-рентгенолог отделения лучевой диагностики, Коммунального некоммерческого преприятия Львовского областного совета «Западноукраинский специализированный детский медицинский центр»; Центр медицинских инноваций NOVO. Адрес: г. Львов, ул. Пылыпа Орлика, 4.

«Западноукраинский специализированный детский медицинский центр»; Центр медицинских инноваций NOVO. Адрес: г. Львов, ул. Пылыпа Орлика, 4. Мих Алла Николаевна - врач-цитолог клинической лаборатории Коммунального некоммерческого преприятия Львовско

Статья поступила в редакцию 15.09.2018, принята к печати 04.12.2018.

\section{ДО УВАГИ АВТОРІВ!}

\section{AЛIГОРИTM РЕССТРАЦIÏ ORCID}

\section{Open Researcher and Contributor ID (ORCID) - міжнародний ідентифікатор науковця}

Створення єдиного реєстру науковців та дослідників на міжнародному рівні є найбільш прогресивною та своєчасною ініціативою світового наукового товариства. Ця ініціатива була реалізована через створення в 2012 році проекту Open Researcher and Contributor ID (ORCID). ORCID - це реєстр унікальних ідентифікаторів вчених та дослідників, авторів наукових праць та наукових організацій, який забезпечує ефективний зв'язок між науковцями та результатами іх дослідницької діяльності, вирішуючи при цьому проблему отримання повної і достовірної інформації про особу вченого в науковій комунікації.

Для того щоб зареєструватися в ORCID через посилання https://orcid.org/ необхідно зайти у розділ «For researchers» i там натиснути на посилання «Register for an ORCID iD».

В реєстраційній формі послідовно заповнюються обов'язкові поля: «First name», «Last name», «E-mail», «Re-enter E-mail», «Password» (Пароль), «Confirm password»

В перше поле вводиться ім'я, яке надане при народженні, по-батькові не вводиться. Персональна електронна адреса вводиться двічі для підтвердження. Вона буде використовуватися як Login або ім'я користувача. Якщо раніше вже була використана електронна адреса, яка пропонується для реєстрації, з'явиться попередження червоного кольору. Неможливе створення нового профілю з тією ж самою електронною адресою. Пароль повинен мати не менше 8 знаків, при цьому містити як цифри, так і літери або символи. Пароль, який визначається словами «Good» або «Strong» приймається системою.

Нижче визначається «Default privacy for new works», тобто налаштування конфіденційності або доступності до персональних даних, серед яких «Public», «Limited», «Private».

Далі визначається частота повідомлень, які надсилає ORCID на персональну електронну адресу, а саме, новини або події, які можуть представляти інтерес, зміни в обліковому записі, тощо: «Daily summery», «Weekly summery», «Quaterly summery», «Never». Необхідно поставити позначку в полі «I'm not a robot» (Я не робот).

Останньою дією процесу реєстрації є узгодження з політикою конфіденційності та умовами користування. Для реєстрації необхідно прийняти умови використання, натиснувши на позначку «I consent to the privacy policy and conditions of use, including public access and use of all my data that are marked Public».

Заповнивши поля реєстраційної форми, необхідно натиснути кнопку «Register», після цього відкривається сторінка профілю учасника в ORCID з особистим ідентифікатором ORCID ID. Номер ORCID ідентифікатора знаходиться в лівій панелі під ім'ям учасника ORCID.

Структура ідентифікатора ORCID являє собою номер з 16 цифр. Ідентифікатор ORCID - це URL, томy запис виглядає як http://orcid.org/xxxx-xxxx-xxxxxxxx.

Наприклад: http://orcid.org/0000-0001-7855-1679.

Інформацію про ідентифікатор ORCID необхідно додавати при подачі публікацій, документів на гранти і в інших науково-дослідницьких процесах, вносити його в різні пошукові системи, наукометричні бази даних та соціальні мережі.

Подальша робота в ORCID полягає в заповненні персонального профілю згідно із інформацією, яку необхідно надавати. 


\title{
Н.И. Макеева ${ }^{1,2}$, Ю.В. Одинец ${ }^{1,2}$, И.Н. Поддубная ${ }^{1,2}$ \\ Остеонекроз как осложнение полихимиотерапии у детей, страдающих острым лейкозом
}

\author{
'Харьковский национальный медицинский университет, Украина \\ ${ }^{2}$ Коммунальное некоммерческое предприятие «Городская клиническая детская больница №16» \\ Харьковского городского совета, Украина
}

SOVREMENNAYA PEDIATRIYA.2018.8(96):87-91; doi 10.15574/SP.2018.96.87

Применение протоколов полихимиотерапии (ПХТ) привело к значительному повышению выживаемости детей, страдающих острым лимфобластным лейкозом (ОЛЛ), но и повлекло за собой неблагоприятные последствия, среди которых одним из наиболее распространенных становится остеонекроз, существенно влияющий на качество жизни пациентов. Результаты изучения факторов риска развития остеонекроза противоречивы. Стандарты терапии данного осложнения окончательно не разработаны.

Цель: привлечь внимание гематологов к ранней диагностике остеонекроза у детей, страдающих олЛ.

Материалы и методы. Приведены данные обследования и лечения детей, страдающих онкогематологической патологией, у которых на фоне терапии развился остеонекроз.

Результаты. При подтверждении диагноза остеонекроза с помощью МРТ в терапии использовались хондропротекторы и иломедин, позволившие достигнуть ремиссии.

Выводы. В связи с бессимптомностью течения остеонекроза у детей, страдающих онкогематологическими заболеваниями, при подозрении на развитие данного осложнения на фоне проводимой ПХТ необходимо проводить МРТ. Терапия, направленная на предотвращение прогрессирования остеонекроза и фуннциональных нарушений, требует дальнейшей разработки.

Ключевые слова: остеонекроз, лейкоз, дети.

\section{Osteonecrosis as a complication of polychemotherapy in children suffering from acute leukemia \\ N. Makieieva ${ }^{12}$, Yu. Odinets ${ }^{12}$, I. Poddubnaya ${ }^{12}$ \\ ${ }^{1}$ Kharkiv National Medical University, Ukraine \\ ${ }^{2}$ Communal non-profit enterprise «Municipal Clinical Children's Hospital №16» of the Kharkiv City Council, Ukraine}

The use of polychemotherapy (PCT) protocols resulted in a significant increase in the survival rate in children suffering from acute lymphoblastic leukemia (ALL), but also gave rise to adverse consequences, among which osteonecrosis, which significantly alters the quality of life of patients, is one of the most common. The results of risk factors' study for osteonecrosis development are controversial. Standards for treatment of this complication are not finally created.

Aim: to attract the attention of hematologists to the early diagnostics of osteonecrosis in children suffering from ALL.

Materials and methods: data of examination and treatment of the children suffering from oncohematological disorders, who developed osteonecrosis during therapy, are given.

Results: when the diagnosis of osteonecrosis has been confirmed using MRI, chondroprotectors and ilomedine were used in therapy, that allowed to induce remission.

Conclusions: Due to asymptomatic course of osteonecrosis in children suffering from oncohematological diseases, as soon as development of this complication on the background of the ongoing polychemotherapy is suspected, MRI must be performed. Therapy focused on preventing the progression of osteonecrosis and functional impairment requires further development.

Key words: osteonecrosis, leukemia,children.

\section{Остеонекроз як ускладнення поліхіміотерапії у дітей, які страждають на гострий лейкоз

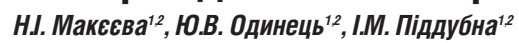

'Харківський національний медичний університет, Україна

${ }^{2}$ Комунальне некомерційне підприємство «Міська клінічна дитяча лікарня №16» Харківської міської ради, Україна

Застосування протоколів поліхіміотерапії (ПХТ) призвело не тільки до значного підвищення виживаності дітей, які страждають на гострий лімфобластний лейкоз (ГЛЛ), але й до несприятливих наслідків, серед яких одним з найбільш поширених стає остеонекроз, що істотно впливає на якість життя пацієнтів. Результати вивчення факторів ризику розвитку остеонекрозу суперечливі. Стандарти терапії даного ускладнення остаточно не розроблені.

Мета: привернути увагу гематологів до ранньої діагностики остеонекрозу у дітей, які страждають на ГЛЛ.

Матеріали і методи. Наведені дані обстеження і лікування дітей з онкогематологічною патологією, у яких на тлі терапії розвинувся остеонекроз.

Результати. При підтвердженні діагнозу остеонекрозу за допомогою МРТ у терапії використовувалися хондропротектори та іломедін, що дозволило досягти ремісії.

Висновки. У зв'язку із безсимптомним перебігом остеонекрозу у дітей, які страждають на онкогематологічні захворювання, за підозри на розвиток даного ускладнення на тлі застосовуваної ПХТ необхідно проводити МРТ. Терапія, спрямована на запобігання прогресуванню остеонекрозу і функціональних порушень, вимагає подальшої розробки.

Ключові слова: остеонекроз, лейкоз, діти.

\section{Введение}

$\Pi^{1}$ рименение протоколов полихимиотерапии ПХТ привело к значительному повышению выживаемости детей, стра- дающих острым лимфобластным лейкозом (ОЛЛ). Однако подобная агрессивная химиотерапия влечет за собой неблагоприятные последствия, среди которых одним из наи- 
более распространенных становится остеонекроз, существенно влияющий на качество жизни пациентов [3].

До недавнего времени остеонекроз считался редким осложнением терапии лейкоза. Первое сообщение об остеонекрозе как серьезной проблеме химиотерапии было опубликовано в 2000 г. Частота его, по данным различных исследований, колеблется от 1,6 до 17,6\% [6], что связано, вероятно, с недооценкой возникновения остеопороза в ретроспективных исследованиях и рассмотрением различных возрастных групп пациентов.

Особенностью данной патологии является то, что она зачастую протекает бессимптомно и выявляется только с помощью МРТ [5].

Среди разнообразных рассматриваемых факторов риска развития остеонекроза наиболее значимым оказался возраст, при этом выявлено, что наибольшему риску подвержены дети старше 10 лет [1]. Очевидно, увеличение скорости роста и специфические гормональные изменения в этот период жизни, влияющие на морфологию костной ткани, ее метаболизм и кровоснабжение, опосредованно предрасполагают к развитию остеопороза. Все механизмы, приводящие к возникновению остеопороза, сводятся к нарушению кровоснабжения кости и включают внутрисосудистое свертывание/эмболии (внутрипросветная облитерация), повышение давления в костном мозге (внепросветная облитерация) и непосредственное повреждение кровеносных сосудов. К остеонекрозу может предрасполагать и прямое токсическое действие химиотерапии [8].

Основными факторами риска развития остеонекроза являются глюкокортикостероиды, при этом совокупная доза полученных ГК коррелирует с риском остеонекроза [7].

Доказано влияние на развитие остеонекроза таких препаратов, как аспарагиназа и метотрексат [9]. Алкилирующие агенты повреждают функцию гонад, что приводит к гипогонадизму и нарушению костной минерализации. Ифосфамид может индуцировать гипофосфатемический рахит, нарушающий структуру костей, а пуриновые антиметаболиты могут нарушать пролиферацию хондроцитов [6].

Не удалось связать риск развития остеонекроза с фенотипом лейкоза [2].

Данные относительно разницы в рисках развития данного осложнения между мальчиками и девочками противоречивы. Даже в группах, которые использовали по существу один и тот же режим лечения, в этом отношении имеются разрозненные результаты. Также нет единогласия в отношении влияния ожирения и ИМТ как факторов риска [6].

Тщательная оценка побочных эффектов и токсичности терапии у детей, страдающих лейкозом, является важным аспектом современной терапии для снижения риска возникновения неблагоприятных результатов.

В настоящее время проводится многоцентровое исследование OPAL (Osteonecrosis in Pediatric patients with Acute lymphoblastic Leukemia and lymphoblastic lymphoma), в котором проспективно оценивают детей, страдающих острым лейкозом и лимфобластной лимфомой и получающих ПЛХ по протоколам AIEOP-BFM 2009 и CoALL-08-09, тщательно оценивая специфические жалобы в отношении поражения опорно-двигательного аппарата, проводя функциональные исследования и МРТ в определенные отрезки времени на протяжении лечения. Целью исследования является определение контингента детей, у которых может быть диагностирован ранний бессимптомный остеонекроз с помощью МРТ, выявление критических моментов его развития и описание его естественного течения [5].

В терапии остеонекроза предлагаются как оперативные, так и неоперативные методы лечения. Хирургическое вмешательство может уменьшить боль и улучшить подвижность, но стандартов лечения у детей нет. Показано, что хирургическое лечение безопасно даже у пациентов в тяжелом состоянии и пациентов, продолжающих получать поддерживающую терапию по поводу ОЛЛ [4].

Обсуждается возможность применения гипербарической оксигенации, которая у детей младше 10 лет приводила к снижению количества случаев развития остеонекроза и перехода их в отек костного мозга, но не предупреждала возникновения новых очагов поражения и не улучшала исходов уже существующих очагов поражения у детей старше 10 лет. Отмечались незначительные побочные явления в виде раздражения барабанной перепонки и среднего уха.

Назначение аналога простациклина илопроста на ранних стадиях развития поражений костной системы приводило к облегчению боли и улучшению функции суставов, но оказалось неэффективным на поздней стадии заболевания. В качестве побочных явлений описаны головная боль, тошнота, рвота и флебит [5]. 
В ряде исследований у небольшого количества детей, страдавших острым лейкозом, отмечен положительный эффект в отношении уменьшения болевого синдрома и увеличения объема движений в пораженных суставах при применении бифосфонатов (алендроната, памидроната и золедроновой кислоты), но не в отношении рентгенологических исходов [10].

\section{Клинические наблюдения}

Под нашим наблюдением находилось трое пациентов, страдающих ОЛЛ и Ходжкинской лимфомой, у которых развился асептический остеонекроз.

Ребенок Л., 11 лет, поступил в гематологическое отделение Харьковской городской клинической детской больницы №16 04.12.2013 г. с жалобами на боль в костях, утомляемость. Из анамнеза жизни известно, что впервые жалобы появились около года назад; 01.12.13 состояние ребенка ухудшилось, усилились боли в конечностях, появилась выраженная слабость, утомляемость. С 03.12.2013 по 04.12.13 девочка находилась в Валковской ЦРБ, где при обследовании в клиническом анализе крови выявлены бластные клетки 7\%, изменения в виде лейкоцитоза $30,6 \times 10^{9}$ /л, лимфоцитоза $82 \%$; заподозрен острый лейкоз, ребенок направлен в гематологическое отделение. При поступлении обращали на себя внимание умеренная бледность кожных покровов, полиаденопатия, гепатоспленомегалия. В клиническом анализе крови выявлено 54\% бластных клеток, тромбоцитопения, лейкоцитоз со сдвигом влево. В миелограмме (по результатам цитохимического и иммунофенотипического исследования бластных клеток) - острый лимфобластный лейкоз, common ALL. При цитогенетическом исследовании костного мозга выделена филадельфийская хромосома.

Диагноз: «Острый лимфобластный лейкоз, ФАБ-вариант L1, common ALL, с коэкспрессией T-клеточного антигена CD4 BCR/ABL-позитивный, 1-я костномозговая ремиссия. Диспластическая кардиопатия (ложная хорда левого желудочка). Токсико-метаболическая полинейропатия. Синдром ликворной дистензии с легким вестибулярным и астеническим синдромами»

Ребенку был начат курс химиотерапии по протоколу I программы ALLIC BFM $2009+$ гливек 300 мг/сут с 8-го дня терапии.

На 8-й день ПХТ достигнут положительный ответ на профазу ( $0 \%$ бластных клеток в клиническом анализе крови), на 15-й день терапии была достигнута костномозговая ремиссия (в миелограмме популяция лейкемических бластов составляла 0,034\% нуклеированных клеток, что соответствует статусу FLR). На 18-й день ПХТ развилась цитостатическая болезнь: миелосупрессивный синдром (анемия, тромбоцитопения), острый панкреатит, острый гастрит, парез кишечника, токсическая энтеропатия, токсический гепатит, острый бронхит простой, в связи с чем ПХТ была остановлена. Развившийся парез кишечника и контактный перитонит потребовали хирургического вмешательства (29.12.13 г.). После окончания протоколов I, M и II протоколов наступила ремиссия заболевания. В апреле на фоне проведения поддерживающей терапии пуринетолом, метотрексатом, бисептолом и гливеком на МРТ диагностирован асептический некроз эпифизов большеберцовой и бедренной костей и головки плечевой кости. В терапии назначены хондропротекторы, местно аппликации долобене, инфузии аналогом простациклина иломедином №5. В сентябре на контрольной МРТ отмечалось нарастание процессов отграничения в отдельных участках асептических некрозов, появление зоны отека в дистальном метафизе бедренной кости. Поддерживающая терапия была отменена в декабре 2015 г. При контрольном обследовании в мае 2017 г. констатирована стойкая ремиссия. Ребенок находится под диспансерным наблюдением гематолога и ортопеда по настоящее время.

Ребенок П., 15 лет, поступил в гематологическое отделение Харьковской городской клинической детской больницы №16 12.04.2013 г., жалоб на момент осмотра не предъявлял. Из анамнеза известно, что ребенок болен с 12.03.13, когда появились жалобы на отечность и болезненность нижних конечностей, кашель, насморк. В течение 10 дней получал лечение по месту жительства по поводу острого простого бронхита, реактивного артрита. Состояние ухудшалось - увеличились отеки в области голеностопных суставов, и с диагнозом «Реактивный артрит» ребенок направлен на лечение в областную больницу, где получал лечение в течение 10 дней по поводу язвенной болезни луковицы 12-перстной кишки, фазы обострения, рефлюкс-эзофагита, недифференцированной дисплазии соединительной ткани. 12.04.13 г. в клиническом анализе крови были выявлены недифференцированные клетки, в связи с чем ребенок был переведен в гематологическое отделение с диагнозом «Острый 
лейкоз». При поступлении обращали на себя внимание микрополиадения, умеренная гепатомегалия. В клиническом анализе крови отмечался лейкоцитоз, бластные клетки составляли $62,5 \%$. По данным иммунофенотипирования диагностирован острый лимфобластный Т-линейный лейкоз с экспрессией антигена стволовых клеток CD34+, коэкспрессией двух миелоидных антигенов CD13, CD33 и одного B-линейного антигена CD19, ФАБ вариант L2. Язвенная болезнь луковицы 12-перстной кишки, фаза ремиссии, рефлюкс-эзофагит. Хронический вирусный гепатит В умеренной активности и высокой вирусной нагрузки.

На 8-й день ПХТ ответ на профазу был плохим, на 15-й день костномозговая ремиссия не достигнута (MRD 43,11\% нуклеированных клеток, что соответствует статусу FHR, бластные клетки - 32,6\%). На 33-й день костномозговая ремиссия не достигнута (MRD 18\% нуклеированных клеток, что соответствует статусу FHR, бластные клетки - 3,2\%).

Костномозговая ремиссия достигнута только на 52-й день ПXТ (MRD не более 0,52\% нуклеированных клеток, бластные клетки 0,6\%). При проведении ПХТ отмечались осложнения в виде токсического гепатита, жирового гепатоза, анемии тяжелой степени, обострения язвенной болезни, развития herpes labialis, миелосупрессивного синдрома, вторичной кардиопатии, двусторонней пневмонии, осложненной фибринозным плевритом. Отмечалась аллергическая реакция на введение аспарагиназы в виде озноба, повышения температуры до фебрильных цифр. 25.07.15 г. диагностирован асептический некроз головок обеих бедренных костей, инфарктов в шейках межвертебральных областях обеих бедренных костей, асептический некроз эпифизов большеберцовой и бедренной костей, по поводу чего получил инъекции иломедина, хондропотекторы per os, мовалис per os, артрофон. При контрольном обследовании в марте 2018 г. констатирована ремиссия.

Пациент H., 15 лет, поступила в гематологическое отделение КУОЗ Харьковской городской клинической детской больницы №16 в октябре 2014 года с жалобами на снижение аппетита, повышение температуры тела до $38^{\circ} \mathrm{C}$, затрудненное дыхание, общую слабость.

Из анамнеза известно, что ребенок болен с августа 2014 года, когда впервые появились вышеуказанные жалобы. Лечилась у ЛОР- врача. В октябре 2014 года ребенку проведена видеоторакоскопическая биопсия опухоли средостения справа. Гистологическое заключение: «Лимфогранулематоз, нодулярный склероз». Для дальнейшего лечения ребенок переведен в гематологическое отделение 03.10.2014 года.

При поступлении обращало на себя внимание увеличение надключичных лимфоузлов справа до 1,5 см. В лабораторных исследованиях отмечались повышенные титры антител к ЦМВ, вирусу Эпштейн-Барра, гепатиту В и вирусу простого герпеса. На КТ грудной клетки и брюшной полости признаки правостороннего пневмогидроторакса с коллабированием правого легкого на 1/3. Обширная неопластическая масса средостения с окутыванием крупных сосудов, лимфоаденопатия аортокаротидной, парастернальных и нижнеяремных областей, вероятно, как проявление лимфопролиферативного заболевания. Гепатоспленомегалия. При иммуногистохимическом исследовании выявлена морфологи ческая картина лимфомы Ходжкина, смешанно-клеточный вариант. Проведено восемь курсов химиотерапии ВЕАСОРР. После каждого блока химиотерапии у ребенка отмечались осложнения - миелосупрессивный синдром, токсический гепатит, астенический синдром на фоне гипоксически-дисметаболической энцефалопатии с синдромом вегетативно-висцеральных нарушений. При контрольной КТ после восьми блоков отмечалось некоторое уменьшение размеров массы переднего средостения. В мае 2015 года проведен курс лучевой терапии на область средостения в суммарной дозе 34 ГР. Осложнений не отмечено. При контрольной КТ в июле 2015 отмечалось некоторое уменьшение размеров массы переднего средостения и появление асептического некроза в головках обеих плечевых и бедренных костей, по поводу чего получала хондропротекторы и иломедин. При контрольном обследовании в июне 2017 г. констатирована ремиссия.

Исследования проводились в соответствии с принципами Хельсинкской Декларации. Протокол исследования был одобрен Локальным этическим комитетом (ЛЭК) всех участвующих учреждений. На проведение исследований было получено информированное согласие родителей детей (или их опекунов). 


\section{Выводы}

1. В связи с участившимися случаями развития остеонекрозов на фоне проводимой ПХТ онкогематологических заболеваний и бессимптомности его течения у детей старше 10 лет целесообразно тщательно оценивать специфические жалобы в отношении поражения опорно-двигательного аппарата и прово- дить МРТ в определенные отрезки времени на протяжении лечения.

2. Полученных данных недостаточно для оценки вмешательств, направленных на предотвращение прогрессирования остеонекроза и функциональных нарушений.

Авторы заявляют об отсутствии конфликта интересов.

\section{ЛИТЕРАТУРА}

1. Amin NL, Feltbower R, Kinsley S et al. (2017). Osteonecrosis in patients with acute lymphoblastic leukaemia: a national questionnaire study. BMJ Paediatrics Open. 1:1-7.

2. Amin NL, Kinsey S, Feltbower R et al. (2015). Analysis of Long-Term Outcomes, Management and Prevalence of Osteonecrosis in UKALL 2003: $3.5 \%$ of Adolescents and Young Adults over 10 Years of Age with Acute Lymphoblastic Leukaemia Required Hip Replacement. Blood. 126(23):2083-2083.

3. Girard P, Auquier P, Barlogis V et al. (2013). Symptomatic osteonecrosis in childhood leukemia survivors: prevalence, risk factors and impact on quality of life in adulthood. Haematologica. 98(7):1089-1097.

4. Heneghan MB, Rheingold SR, LiY. (2016). Treatment of Osteonecrosis in Children and Adolescents with Acute Lymphoblastic Leukemia. Clin Lymphoma Myeloma Leuk. 16(4):223-229.

5. Kuhlen M, Kunstreich M, Krull K et al. (2017). Osteonecrosis in children and adolescents with acute lymphoblastic leu- kemia: a therapeutic challenge. Blood advances. 1(14): 981-994.

6. Kunstreich M, Kummer S, Laws H-J et al. (2016). Osteonecrosis in children with acute lymphoblastic leukemia. Haematologica. 101(11):1295-1305.

7. Liu LH, Zhang QY, Sun W, Li ZR, Gao FQ. (2017). Corticosteroid-induced Osteonecrosis of the Femoral Head: Detection, Diagnosis, and Treatment in Earlier Stages. Chin Med J. 130:2601-2607.

8. Marenzana M, Arnett TR. (2013). The Key Role of the Blood Supply to Bone. Bone Research. 1:203-215.

9. Muller HL, Langer T, Schnabel D. (2015). Growth and bone metabolism after oncological disease in childhood and adolescence. Monatsschr Kinderheilkd.163(2):135-141.

10. Riccio I, Pota E, Marcarelli M et al. (2016). Osteonecrosis as a complication in pediatric patients with acute lymphoblastic leukemia. La Pediatria Medica E Chirurgica. 38(3):80-86.

\section{Сведения об авторах:}

Макеева Наталия Ивановна - д.мед.н., проф., зав. каф. педиатрии №2 Харьковского НМУ. Адрес: г. Харьков, просп. Науки, 4; тел. (0572) 95-40-93.

Одинец Юрий Васильевич - д.мед.Н., проф. каф. педиатрии №2 Харьковского НМУ. Адрес: г. Харьков, просп. Науки, 4; тел. (0572) 95-40-93.

Поддубная Ирина Николаевна - к.мед.Н., доц. каф. педиатрии №2 Харьковского НМУ. Адрес: г. Харьков, просп. Науки, 4; тел. (0572) 95-40-93.

Статья поступила в редакцию 17.07.2018, принята к печати 24.11.2018. 


\title{
С.А. Бегларян, Л.І. Чернишова \\ Підходи до розробки клінічних критеріїв випадків, підозрілих щодо первинного імунодефіциту (огляд літератури)
}

\author{
Національна медична академія післядипломної освіти імені П.Л. Шупика, м. Київ, Україна
}

\author{
SOVREMENNAYA PEDIATRIYA.2018.8(96):92-98; doi 10.15574/SP.2018.96.92
}

Станом на 2018 рік відомо понад 350 нозологій первинних (вроджених) імунодефіцитів (Під). Більшість випадків вроджених імунодесріцитів залишаються не діагностованими через відсутність патогномонічних симптомів і низьку настороженість лікарів щодо цієї патології. Наразі пІД не $є$ фратальними, їх можна лікувати. У випадку раннього встановлення діагнозу ПІД у дітей з'являється шанс на повноцінне життя та нерідко на повне одужання. Важливою $є$ розробка критеріїв для визначення випадків, підозрілих на ПІД.

Мета: вивчення підходів до розробки клінічних критеріїв виявлення ПІД.

Матеріали і методи. Проведено збір та аналіз літературних джерел, що стосуються клінічних критеріїв, пов'язаних з проявами ПІД. Проаналізовано 13 робіт.

Результати. У світі, у тому числі в Україні, розроблено ряд критеріїв, які можуть бути клінічними маркерами підозри на вроджений імунодесріцит. Підходи до розробки клінічних критеріїв ПІД були різними: методи розрахунку частоти ознак хвороби, використання чотирипільної таблиці $\chi^{2}$, регресійного аналізу, створення імунодефіцит-пов'язаного показника для оцінки діагнозів госпіталізованих пацієнтів шляхом комп'ютерного скринінгу. Існує лише одна робота, у якій розроблено критерії окремо для дітей і дорослих.

Висновки. Для виявлення пацієнтів з ПІД застосовуються різні методики. Існуючі підходи можуть бути передумовою для подальшої розробки клінічних критеріїв раннього виявлення ПІД.

Ключові слова: дитяча імунологія, первинні імунодефіцити, клінічні критерії.

\section{Approaches to the development of clinical criteria for cases suspected of primary immunodeficiency (literature review) \\ S.A. Beglaryan, L.I. Chernyshova \\ Shupyk National Medical Academy of Postgraduate Education, Kyiv, Ukraine}

Topicality. For 2018, there are more than 350 nosologies of primary immunodeficiencies. Most cases of congenital immunodeficiencies remain undiagnosed due to the absence of pathognomonic symptoms with them and the low level of doctors' awareness of this pathology. Primary (congenital) immunodeficiencies are not fatal nowadays, as they can be treated. In case of the early diagnosing, children get a chance for a full life and, often, a complete recovery. So, development of criteria for identifying cases suspected of primary immunodeficiency is important.

Objective: Study of existing approaches to the development of clinical criteria for the detection of primary immunodeficiencies.

Material and methods. Collection and analysis of existing literature on clinical criteria related to manifestations of primary immunodeficiencies.

Results. We analyzed 13 works about development of criteria for primary immunodeficiencies diagnosis. Throughout the world, including Ukraine, a number of criteria have been developed, which may be clinical markers of suspected congenital immunodeficiency. There were different approaches for the development of clinical criteria for primary immunodeficiencies such as calculating the symptoms frequency, the $\chi^{2}$ fourfold table, regression analysis and making of an immunodeficiency-related score for assessing the hospitalized patients' diagnoses through the computer screening. One work shows separately developed criteria for children and adults.

Conclusions. The analysis of literature showed different methods for identifying patients with primary immunodeficiencies. Existing approaches can be a precondition for the further clinical criteria development for the early detection of primary immunodeficiencies.

Key words: paediatric immunology, primary immunodeficiencies, clinical criteria.

\section{Подходы к разработке клинических критериев случаев, подозрительных относительно первичного иммунодефицита (обзор литературы) \\ С.А. Бегларян, Л.И. Чернышова}

Национальная медицинская академия последипломного образования имени П.Л. Шупика, г. Киев, Украина

По состоянию на 2018 год известно свыше 350 нозологий первичных (врожденных) иммунодефицитов (ПиД). Большинство случаев врожденных иммунодесицитов остаются не диагностированными из-за отсутствия патогномонических симптомов и низкой настороженности врачей относительно данной патологии. В настоящее время ПИД не являются фратальными, их можно лечить. В случае ранней постановки диагноза ПИД у детей появляется шанс на полноценную жизнь и нередко - на полное выздоровление. Важна разработка критериев для определения случаев, подозрительных на ПИД.

Цель: изучение подходов к разработке клинических критериев выявления ПИД.

Материалы и методы. Проведен сбор и анализ литературных источников, касающихся клинических критериев, связанных с проявлениями пиД. Проанализировано 13 работ.

Результаты. В мире, в том числе в Украине, разработан ряд критериев, которые могут быть клиническими маркерами подозрения на врожденный иммунодесицит. Подходы к разработке клинических критериев ПИД были разными: методы расчета частоты признаков болезни, использование четырёхпольной таблицы $\chi^{2}$, регрессионного анализа, создание иммунодесицит-связанного показателя для оценки диагнозов госпитализированных пациентов путем компьютерного скрининга. Существует только одна работа, где разрабатывались критерии отдельно для детей и взрослых.

Выводы. Для выявления пациентов с ПИД применяются различные методики. Существующие подходы могут быть предпосылкой для дальнейшей разработки клинических критериев раннего выявления ПИД.

Ключевые слова: детская иммунология, первичные иммунодесициты, клинические критерии. 


\section{Вступ}

$\prod^{2}$ ервинні імунодефіцити (ПІД) - група генетично обумовлених порушень імунної системи 3 різноманітними проявами. Значна частка ПІД проявляються у дитячому віці.

Для педіатричної практики важливо не просто виявляти пацієнтів з ПІД, а виявляти їх якомога раніше. Це дозволяє уникнути тривалих та вартісних госпіталізацій, інвалідизації та летальності. Рано встановлений діагноз сприяє вчасному лікуванню, що можливо для значної частини цих захворювань. Лікування ПІД надає пацієнтам шанс тривалого повноцінного життя.

За наявності великої кількості пацієнтів впродовж тривалого часу в центрах, які займаються проблемою вродженої імунної патології, часто формують реєстри пацієнтів. Реєстри пацієнтів з ПІД стали сучасним ефективним інструментом аналізу такої захворюваності. Кожна країна зазвичай формує свій національний реєстр, також існують міжнародні реєстри. Статистичні звіти реєстрів публікуються або за весь період дослідження, або зазвичай за останні 5 років. Наприклад, у реєстрах пацієнтів з ПІД України за 20 років (1995-2014рр.), Тунісу за 25 років (1988-2012рр.), Великобританії за 2008-2012 рр. та 2012-2017 рр., звітах ESID на основі Європейського реєстру можна помітити, що з роками не лише підвищується кількість нових пацієнтів за кожний наступний рік, але й з'являються нові діагнози, змінюючи співвідношення нозологічних груп ПІД [4,21,24,25]. Власне цю тенденцію було проаналізовано у дослідженні «Первинні імунодефіцити у світі: більш часті, ніж зазвичай здається» після аналізу 169 статей, присвячених усім доступним і національним, і міжнародним реєстрам ПІД [18].

В Україні ведеться Реєстр пацієнтів з первинними імунодефіцитами [4], за даними якого частота діагностованих ПІД в Україні становить 1,19 на 100000 населення. Згідно з даними Європейського реєстру, цей показник на 100000 населення у Польщі становить 1,44, в Австрії - 1,178, у Словаччині - 1,049, однак в Угорщині цей показник вищий - 3,76, а у Франції максимальний - 6,164 [1]. За даними реєстру UKPID, у Великобританії кількість діагностованих ПІД становить 5,9 на 100000 населення [26].

Реальна частота наявних пацієнтів з ПІд приблизно 1:10000 (не враховуючи дефіцит IgA, який трапляється приблизно в 1 на 700 пацієнтів) [17]. Тобто на мільйон чоловік населення припадає 100 таких пацієнтів. Дослідження точної частоти ПІД непрості, оскільки ці захворювання почали виявляти лише із середини минулого століття та досі є новим напрямом у медицині.

Отже, за даними українського Реєстру первинних імунодефіцитів у дітей, вроджена патологія імунної системи діагностується лише у 1,19:100000 дітей. Тобто зі статистично прогнозованих 100 таких пацієнтів на мільйон населення в Україні виявляється лише 12 пацієнтів. Діагностика їх ускладнена тим, що, по-перше, практикуючі лікарі не мають настороженості щодо ПІД, по-друге, переважна більшість ПІД не мають клінічних патогномонічних ознак.

У світі, за сприяння Jeffrey Modell Foundation, щодо ПІД широко використовуються 10 ознак настороженості [19]. Передусім вони спрямовані на виявлення проявів інфекційного синдрому. Оскільки значну частку ПІД становлять дефіцити антитілоутворення, ці 10 ознак дуже важливі. Однак для раннього виявлення усіх груп ПІД потрібні розширені критерії з додатковими ознаками. На сьогодні відомо понад 350 нозологічних форм ПІД, щороку відкриваються десятки нових. Клінічний перебіг цих недавно відкритих захворювань досить різноманітний. Інфекційний синдром не завжди є першочерговим їх проявом, а іноді взагалі відсутній. Серед певних груп ПІД клінічні прояви можуть починатися з автоімунної, автозапальної, онкологічної патологій. Тому розробка критеріїв виявлення ПІД триває.

Meта: вивчення існуючих підходів до розробки клінічних критеріїв раннього виявлення ПІД.

\section{Матеріал і методи дослідження}

Проведено збір та аналіз літературних джерел, що стосуються клінічних критеріїв, пов'язаних з проявами ПІД.

\section{Результати дослідження та їх обговорення}

Стани, які пізніше були ідентифіковані як прояви імунодефіциту, були описані ще у 20-х рр. ХХ ст. У 1922 р. Шульц описав дорослих пацієнтів з важкою нейтропенією та гангренозними нальотами глотки [22]. У 1926 р. описані неврологічні прояви з атаксією та телеангіектазією [23], а в 1941 р. у роботах Луї-Бар це захворювання описане як нозологічна одиниця [27]. У 1937 р. Альфред Віскотт виділив в окре- 
мий синдром патологію новонароджених хлопчиків з двох родин, які мали вроджену тромбоцитопенію зі зменшенням розмірів тромбоцитів, а також повторні середні отити [29]. У 1954 р. американський педіатр Роберт Олдрич вивчав шість поколінь голландської сім'ї та відмітив кілька смертей чоловіків у ранньому віці від схожого захворювання.

Історія власне ПІД починається з дефіцитів антитілоутворення, коли американський педіатр Огден Брутон у 1952 р. відкрив захворювання 3 відсутністю гаммаглобулінової фракції у молодого хлопця [10]. Пізніше це захворювання отримало назву агаммаглобулінеміі Брутона (Btk, X-зчеплена агаммаглобулінемія).

В останній затвердженій класифікації ПІД (International Union of Immunology Societies, 2017) наведено вже 354 нозологї, для кожної з яких вказані найбільш характерні ознаки [16]. Ці прояви зазвичай свідчать про розвиток розгорнутої клініки і не завжди є ранніми ознаками хвороби.

У 1993 р. працівники Jeffrey Modell Foundation одними з перших розробили 10 ознак настороженості щодо ПІД, які постійно уточнювалися шляхом опитування лікарів клінічних та академічних баз Мережі центрів Jeffrey Modell, що включає дані з понад 80 країн [13,14,15]. Також серед рекомендацій Jeffrey Modell описані окремо 10 підозрілих ознак ПІД для дорослих. Передбачається, що наявність двох ознак з наведених десяти свідчить про випадок підозри на ПІД. Тобто фактично це критерії підозрілого випадку за визначенням Всесвітньої організації охорони здоров'я для інших нозологічних форм захворювань $[8,9,20]$.

Також, відповідно до звітів Мережі центрів Jeffrey Modell, спостерігається тенденція до зміни відносної структури відомих груп ПІД. Частота дефіцитів антитілоутворення становить 51,62\% у 2011 р., 45,13\% у 2018 р., частота імунодефіцитів із характерними синдромами - 15,62\% у 2011 р., 13,23\% у 2018 р. Група неуточнених ПІД з третього місця протягом останніх десятирічь за кількістю пацієнтів вийшла на друге місце у 2018 р., склавши 15,04\% [13,14].

Десять ознак настороженості Jeffrey Modell щодо ПІД були проаналізовані у ретроспективному дослідженні даних 563 дітей у Регіональних центрах дитячої імунології Королівського дитячого госпіталю Манчестера та Головного госпіталю Ньюкасла [6,28]. 3 них 430 вже мали встановлений діагноз ПІД. А в 133 дітей, що мали підозру, діагноз ПІД після детального обстеження не був підтверджений.

Аналіз також показав, що серед 10 ознак підозри на ПІД наявні більш значущі ознаки, ніж інші [28]. Пацієнти були розподілені на підгрупи за імунологічними ураженнями: нейтрофілів, Т-лімфоцитів, В-лімфоцитів, комплементу. Також окремо виділену підгрупу пацієнтів, у яких ПІД лабораторно не підтвердився. До кожної підгрупи застосували 10 ознак настороженості ПІД. Для оцінки запропонованих критеріїв використовували статистичні методи $\chi^{2}$ та логістичної регресіі. За методом $\chi^{2}$ оцінювалася частота ознак, що зустрічалися у дітей. За допомогою методу логістичної регреcii було порівняно відносні ризики клінічних проявів у кожній з цих підгруп щодо підгрупи 3 лабораторно підтвердженою відсутністю імунодефіциту. Було встановлено, що такі ознаки, як наявність ПІД у родині пацієнта, наявність в анамнезі пацієнта сепсису (із введенням внутрішньовенних антибактеріальних або протигрибкових препаратів), наявність затримки росту та маси тіла, трапляються частіше, тому в якості критеріїв можуть застосовуватися першочергово. В анамнезі пацієнтів групи дослідження зі встановленим діагнозом ПІД ці три ознаки ідентифікували 96\% дітей з дефіцитами нейтрофілів та комплементу і 89\% дітей з імунодефіцитами Т-клітинної ланки.

Важливість родинного анамнезу заперечити неможливо, цей критерій очевидний. Але слід зазначити, що як всі 10 ознак настороженості, так і 3 більш значущі з них, аналізувалися лише серед пацієнтів, імунну патологію яких у 96\% випадках запідозрили лікарі стаціонарів. Ці діти колись вже мали хвороби з показаннями до госпіталізації - сепсис, пневмонію, іншу гнійну або грибкову патологію. Тобто запропонований алгоритм 3 великою вірогідністю не ідентифікує дітей, які ще не були госпіталізовані, яким ще не проводилися серологічні та генетичні дослідження, але у яких перші ознаки імуноскомпрометованості вже проявилися, лікування яких могло бути амбулаторним, у тому числі повторним. Тому запропонований авторами дослідження алгоритм можна використовувати для вже госпіталізованих дітей з важкими, рідкісними або повторними інфекціями, але не для всіх ПІД, прояви яких на ранньому етапі можуть не включати інфекційний синдром або наростати поступово, без ранніх госпіталізацій. Крім того, основні лабораторні скринінгові методи виявлення імунної патоло- 
гії (оцінка рівня антитіл, нейтрофілів, комплементу) можуть не виявити певні нозології вроджених імунодефіцитів.

Ще в наведеній вище роботі показано, що 96\% пацієнтів з підозрою на ПІД були виявлені лікарями, які працюють у стаціонарах. Інформування лікарів про ПІД дійсно має позитивний ефект щодо виявлення імуноскомпрометованих пацієнтів. Наприклад, заходи J Project у Східній та Центральній Європі підвищили настороженість лікарів щодо вроджених імунодефіцитів [12].

Крім 10 ознак настороженості щодо ПІД існують також інші діагностичні критерії. Відомий ряд німецьких критеріїв наявності ПІД: 12 ознак DSAI (Німецької пацієнтської організації первинних імунодефіцитів), 10 ознак AWMF (Асоціації наукових медичних спілок Німеччини) та Дюссельдорфські ознаки настороженості. Методика їх розробки заснована на тих самих принципах, що й 10 ознак Jeffrey Modell Foundation, маючи в основі вибірку пацієнтів у Німеччині [11]. Оцінка частотності критеріїв показала важливість сімейного анамнезу, наявності важкого інфекційного синдрому та затримки росту й маси тіла як першочергових критеріїв. Результат аналізу німецьких критеріїв підтвердив результат наведеного вище дослідження 10 критеріїв Jeffrey Modell Foundation щодо групи пацієнтів з ПІД у Великобританії.

В Україні розробкою клінічних критеріїв ПІД у дітей активно займалися А.П. Волоха (дефіцити антитілоутворення, 2009), Л.В. Костюченко (комбіновані імунодефіцити, 2012), А.В. Бондаренко (створення українського реєстру дітей 3 первинними імунодефіцитами, 2015) у своїх докторських дисертаціях під керівництвом проф. Л.І. Чернишової.

Л.В. Костюченко у роботі «Виявлення, верифікація та медичний супровід первинних комбінованих імунодефіцитів у дітей» досліджувала клінічний та імунний статус дітей з комбінованими ПІД [3]. Було вивчено особливості клінічної маніфестації та перебігу окремих форм комбінованих імунодефіцитів у дітей в Україні 3 оцінкою значущості окремих синдромів. 3 приводу клінічних ознак була оцінена частота патогномонічних симптомів, даних сімейного анамнезу та віку початку проявів при різних нозологічних формах первинних комбінованих імунодефіцитів. Клінічні прояви імунодефіциту також оцінювалися за віком пацієнтів, за допомогою кривої Каплана-Мейера було показано виживання пацієнтів з окремими нозологіями первинних комбінованих імунодефіцитів.

У роботі А.В. Бондаренко «Діагностика та медико-соціальний супровід первинних імунодефіцитів у дітей» [1] було проаналізовано дані 820 виявлених пацієнтів з ПІД в Україні за попередні 20 років. Було створено реєстр пацієнтів. На основі анамнезу 402 пацієнтів з ПІД та 915 дітей групи порівняння без ПІД та 3 використанням чотирипільної таблиці (латинський квадрат) були оцінені клінічні ознаки ПІД, а саме чутливість, специфічність та прогностичне діагностичне значення клінічних ознак. Крім оцінювання частоти клінічних проявів, у роботі розглядалися вік та локуси саме перших клінічних проявів ПІД.

У 2015 р. у рамках науково-дослідницької роботи «Клініко-імунологічна характеристика первинних імунодефіцитів у дітей, розробка критеріїв ранньої діагностики первинних імунодефіцитів» (2012-2016) кафедри дитячих хвороб та дитячої імунології НМАПО імені П.Л. Шупика під керівництвом проф. Л.І. Чернишової був розроблений Інформаційний лист про нововведення в сфері охорони здоров'я №226-2015 «Критерії підозрілого випадку щодо первинного імунодефіциту у дітей (покази до обов'язкового направлення до дитячого імунолога)». Було запропоновано 20 критеріїв настороженості [5].

Цікавий підхід до вивчення захворюваності та госпіталізацій був запропонований в американському дослідженні «Виявлення недіагностованих первинних імунодефіцитних захворювань у суб'єктів національних меншин шляхом використання комп'ютерного сортування діагностичних кодів» (Cunningham-Rundles, Sidi, Estrella, Doucette, 2004). У США ситуація з ПІД подібна до загальносвітової. Вроджена імунна недостатність зустрічається в усіх популяціях, проте лише невелика їх частка діагностується. Автори дослідження намагалися виявити дієвий метод ідентифікації пацієнтів, яким діагноз не встановлений, але прояви імунодефіциту наявні [7]. Методика дослідження передбачала визначення імунодефіцитпов'язаних діагнозів, оцінку кожного такого діагнозу та подальший їх комп'ютерний аналіз. Було розроблено оціночний алгоритм та метод комп'ютерного скринінгу на основі госпіталізацій та кодів хвороб. Медичний центр 
«Гора Синай» обслуговує в основному східний, південний та центральний Гарлем, район НьюЙорка. Також медичний центр є референс-центром для пацієнтів з ПІД, проводить їх лікування.

Були відібрані 174 діагнози (МКХ-9) відповідно до проявів ПІД за даними медичних публікацій. Відібрані діагнози вказані як коди IDR (immunodeficiency disease-related, імунодефіцит-пов'язані). Враховувалися пацієнти віком до 60 років з двома або більше госпіталізаціями з такими діагнозами. Особи з вторинним імунодефіцитом (наприклад, ВІЛ-інфекція, онкопатологія, стан після трансплантацій) були виключені з групи дослідження. Кожний імунодефіцит-пов'язаний діагноз був оцінений у 3, 2 або 1 бали (від клінічно важчих до легших захворювань), сума цих балів була названа як імунодефіцит-пов'язаний показник (IDR score). Хронічні діагнози враховувалися у пацієнта лише по одному разу. Вік, стать, географічні та інші дані пацієнтів групи включення, які мали імунодефіцит-пов'язаний показник 6 і більше балів, порівнювалися з іншими госпіталізованими за той самий період пацієнтами віком до 60 років.

Цей методологічний підхід 3 трибальною шкалою оцінки діагнозів, пов'язаних з вродженими імунодефіцитами, був використаний для вивчення нозологічних форм дефіцитів антитілоутворення у дітей в Україні в роботі (2009р.) А.П. Волохи «Особливості перебігу первинних імунодефіцитів антитілоутворення у дітей, визначення ранніх критеріїв діагностики та обгрунтування дифереційованих підходів до лікування» [2]. Також, використовуючи модель регресійного аналізу зв'язку сумарної оцінки клінічних ознак та імунодефіциту, був розроблений критерій комплексної оцінки клінічних ознак. Цей інтегральний показник (сума балів характерних проявів, оцінених згідно з важкістю у від 1 до 3 балів) у переважної більшості пацієнтів (68\%) з наявністю первинного дефіциту антитілоутворення перевищував 4 бали, на відміну від дітей без такого діагнозу. Такий метод може якісно оцінити ранні прояви, якщо набереться не менше двох проявів інфекційного синдрому дефіцитів антитілоутворення. Проте метод може застосовуватися тільки до дефіцитів антитілоутворення, а це лише половина ПІД у популяції. Точність методу становить 68\%, що є добрим рівнем, проте у частини дітей з дефіцитами антитілоутворення вони будуть залишатися не діагностованими до наступних інфекційних проявів.
Продовжуючи тему дослідження пацієнтів клініки Нью-Йорка [7], комп'ютерний скринінг 187093 пацієнтів (321754 візити стаціонару з 01.01 .1995 до 01.10.2001) виявив 533 особи $(0,28 \%)$, які мали часті госпіталізації. Оскільки дефіцити антитіл складають значну частку ПІД, вибраним програмою пацієнтам робилися аналізи крові на рівні загальних імуноглобулінів, субкласів IgG та поствакцинальних антитіл. Інші маркери крові (лімфопроліферація, нейтропенія, порушення ланки комплементу) були протестовані за наявності показань. Лабораторна діагностика вказаних 533 пацієнтів виявила імунні порушення у 59 з них. Серед цих 59 осіб після лабораторних тестів у 17 були діагностовані різні форми ПІД, у 13 пацієнтів ознаки, асоційовані з вторинним імунодефіцитом (наприклад, серпоподібноклітинна анемія, імуносупресія або апластична анемія). У решти 29 пацієнтів лабораторних імунних дефектів не виявлено. Деякі з них мали бронхіальну астму або інші хронічні захворювання, тому й були відібрані програмою як пацієнти з повторними епізодами хвороб. Домінуючими діагнозами у 935 відібраних програмою пацієнтів з хоча б однією госпіталізацією з імунодефіцит-пов'язаними діагнозами серед 2683 госпіталізацій були пневмонії: неуточнені 813 разів, вірусні або грибкові - 66, інші бактеріальні пневмонії - 56; септицемія - 136, затримка розвитку -127 , емпієма -61 , бронхоектази - 57, остеомієліт - 24. Враховуючи вік досліджуваних пацієнтів (до 60 років), серед 48\% відібраних програмою осіб із сумою імунодефіцит-пов'язаного показника у 6 або більше балів були такі діагнози, як бронхіальна астма (перетиналася у 17\% із пневмоніями), серпоподібноклітинна анемія, цукровий діабет, респіраторний колапс, серцево-судинні захворювання, що не мають відношення до діагнозу імунодефіциту. У пацієнтів із сумою імунодефіцит-пов'язаних діагнозів у 6 балів вікова медіана становила 6,6 року (IQR 2,5-23 роки). Тривалість їх госпіталізації з медіаною 4 дні (IQR 2-7 днів). Інші враховані пацієнти, молодші 60 років та не вибрані комп'ютером як підозрілі щодо ПІД, мали вікову медіану 32,6 року (IQR 13-51,6 року; $\mathrm{P}<0,0001$ ), а термін їх госпіталізації - 3 медіаною 3 дні (IQR 2-6 днів; $\mathrm{P}<0,001)$. Це свідчить про те, що більше госпіталізацій з важкими імунодефіцит-пов'язаними станами трапляються у дитячому віці.

Автори наводять приклад, що враховуючи статистичні дані реальної поширеності ПІД 
[17] та дослідження групи 533 пацієнтів, відібраних комп'ютерним скринінгом, пневмонії (410 пацієнтів з 813 епізодами), ПІД може бути наявним у 41 з них (статистично 10\%). Водночас діагноз підтверджений у 17 (29\%) із 59 осіб, відібраних комп'ютерним оцінюванням. Представлений метод комп'ютерного оцінювання діагнозів з бальною системою не є ідеальним. Але він вже використовувався при аналізі великих груп пацієнтів, наприклад, для оцінки малюкової смертності, зв'язку HDL-холестеролу з коронарними захворюваннями серця, для визначення вартості лікування серпоподібноклітинної анемії. Відносно ПІД при застосуванні всіх алгоритмів комп'ютерний метод пропускає деяких пацієнтів з імунними дефектами та ідентифікує інших без таких дефектів.

Нові критерії скринінгу та діагностики ПІД усе далі відходять від класичних 10 ознак настороженості. Ефективність підходів ранньої діагностики залишається не дуже високою, особливо для нових нозологічних груп імунодефіцитів.

\section{Висновки}

Таким чином, серед оглянутих 13 робіт, що мають відношення до розробки критеріїв підозрілого випадку ПІД, запропоновані підходи розробки критеріїв підозри з використанням різних методик. Для оцінки міжнародної структури вродженої імунної патології, для створення 10 критеріїв Jeffrey Modell Foundation та німецьких критеріїв настороженості щодо ПІД була врахована частота ознак, що проявлялися в клінічних випадках підтвердженого ПІД.
Цей простий, але важливий, метод дозволив описати, оцінити та постійно уточнювати, як проявляються різні вроджені імунодефіцити.

Ефективними методами статистичного аналізу власне клінічних критеріїв ПІД як параметричних ознак є різні модифікації методу $\chi^{2}$. Метод чотирипільної таблиці використаний при аналізі ознак українського реєстру дітей з ПІД та у згаданих британських статтях. Для оцінки прогностичного значення цих критеріїв корисно порівняти критерії як між обраними групами нозологій ПІД, так і з групою дітей зі схожими клінічними ознаками, але без наявності імунної патології. У такому випадку ефективне використання регресійного аналізу. Беручи до уваги поступовий розвиток клінічних ознак у групі пацієнтів з ПІД та неоднорідність цих ознак, статистичним методом вибору є непараметричний метод логістичної регресії, також використаний у британських статтях. Наявні спроби прогнозування з оцінкою імунодефіцитпов'язаних діагнозів із бальною шкалою (IDR score) за допомогою комп'ютерного сортування баз даних медичних інформаційних систем. Аналіз за такою методикою показав, що госпіталізації з важкими імунодефіцит-пов'язаними станами частіше трапляються у дитячому віці, ніж у дорослому. Бальна оцінка використана в українській роботі щодо дефіцитів антитілоутворення за аналогічною шкалою з деякими змінами.

Найбільш ефективні методики можуть бути передумовою для подальшої розробки клінічних критеріїв раннього виявлення випадків, підозрілих щодо імовірності ПІД.

\section{ЛIТЕРАТУРА}

1. Бондаренко АВ. (2016). Діагностика та медико-соціальний супровід первинних імунодефіцитів у дітей. Автореферат дис. Київ: 46.

2. Волоха АП. (2009). Особливості перебігу первинних дефіцитів антитілоутворення у дітей, визначення ранніх критеріїв діагностики та обгрунтування диференційованих підходів до лікування. Автореферат дис. Київ: 40.

3. Костюченко ЛВ. (2012). Виявлення, верифікація та медичний супровід первинних комбінованих імунодефіцитів у дітей. Автореферат дис. Київ: 40.

4. Чернишова ЛІ, Бондаренко АВ, Волоха АП. (2015). Критерії підозрілого випадку щодо первинного імунодефіциту у дітей (покази до обов'язкового направлення до дитячого імунолога). Інформаційний лист про нововведення в сфері охорони здоров'я №226. Київ: 4.

5. Чернишова ЛІ, Бондаренко АВ, Костюченко ЛВ, Савво ОМ, Волоха АП, Рабош ОВ. (2015). Епідеміологія первинних імунодефіцитів в Україні за даними реєстру пацієнтів. Здоровье ребенка. 7: 16-23.

6. Arkwright PD, Gennery AR. (2011). Ten warning signs of primary immunodeficiency: a new paradigm is needed for the 21 st century. Ann N Y Acad Sci. 1238:7-14.

7. Bousfiha AA, Jeddane L, Ailal F et al. (2013). Primary immunodeficiency diseases worldwide: more common than generally thought. J Clin Immunol.33(1):1-7.

8. Cunningham-Rundles C, Sidi P, Estrella L, Doucette J. (2004). Identifying undiagnosed primary immunodeficiency diseases in minority subjects by using computer sorting of diagnosis codes. J Allergy Clin Immunol.113(4):747-55.

9. Defining the term «malaria case». WHO update of malaria terminology. August 2015, Geneva, Switzerland. http://www.who.int/mala$\mathrm{ria} / \mathrm{mpac} / \mathrm{mpac}$-sept2015-terminology-annex1.pdf

10. Edgar JD, Buckland M, Guzman D et al. (2014). The United Kingdom Primary Immune Deficiency (UKPID) Registry: report of the first 4 years' activity 2008-2012. Clin Exp Immunol. 175(1):68-78.

11. Gathmann B, Binder N, Ehl S, Kindle G. (2012). The European internetbased patient and research database for primary immunodeficiencies: update 2011. Clin Exp Immunol.167(3):479-91.

12. Hitzig WH. (2003). The discovery of agammaglobulinaemia in 1952. Eur J Pediatr. 162:289-304.

13. Lankisch P, Schiffner J, Ghosh S, Babor F, Borkhardt A, Laws HJ. (2015). The Duesseldorf warning signs for primary immunodeficiency: is it time to change the rules? J Clin Immunol.35(3):273-9.

14. Louis-Bar D. (1941). Sur un syndrome progressif comprenant des telangiecstasies capillaries cutanees et conjonctivales symetriques a dispositions naevoïde et de truobles cerebelleux. Conf Neurol (Basel). 4:32-42. 
15. Marodi L, Casanova JL. (2009). Primary immunodeficiency diseases: the J Project. The Lancet.373(9682):2179-2181.

16. Mellouli F, Mustapha IB, Khaled MB et al. (2015). Report of the Tunisian Registry of Primary Immunodeficiencies: 25-Years of Experience (1988-2012). J Clin Immunol.35(8):745-53.

17. Modell V, Gee B, Lewis DB et al. (2011). Global study of primary immunodeficiency diseases (PI) - diagnosis, treatment, and economic impact: an updated report from the Jeffrey Modell Foundation. Immuno Res.51(1):61-70.

18. Modell V, Orange JS, Quinn J, Modell F. (2018). Global report on primary immunodeficiencies: 2018 update from the Jeffrey Modell Centers Network on disease classification, regional trends, treatment modalities, and physician reported outcomes. Immunol Res.

19. Modell V, Quinn J, Orange J, Notarangelo LD, Modell F. (2016). Primary immunodeficiencies worldwide: an updated overview from the Jeffrey Modell Centers Global Network. Immunol Res.64(3):736-53.

20. Picard C, Bobby Gaspar H, Al-Herz W et al. (2018). International Union of Immunological Societies: 2017 Primary Immunodeficiency Diseases Committee Report on Inborn Errors of Immunity. Journal of Clinical Immunology.38(1):96-128.

21. Primary Immunodeficiency Diseases Report of an IUIS Scientific Committee (1999, Oct). Clinical and Experimental Immunology. $118(1): 1-28$.
22. Primary immunodeficiency resource center. (2018, April). www.info4pi.org

23. Shillitoe B, Bangs C, Guzman D, et al. The United Kingdom Primary Immune Deficiency (UKPID) registry 2012 to 2017. (2018). Clin Exp Immunol.192(3):284-291.

24. Shultz W. (1922). Ueber eigenartige Halserkraunkungen. (Apropos unusual diseases of the pharynx). Dtsch Med Wochenschr. 48:1495-1497.

25. Subbarayan A, Colarusso G, Hughes SM et al. (2011). Clinical features that identify children with primary immunodeficiency diseases. Pediatrics. 127(5):810-6.

26. Syllaba L, Henner K. (1926). Contribution a L'independence de l'athetose double idiopathique et congenital: atteinte familiale, syndrome distrophique, signe du reseau vasculaire conjonctival, integrite psychique. Rev Neurol (Paris). 1:541-562.

27. WHO. (2013). Guidelines for measles and rubella outbreak investigation and response in the WHO European Region.. http://www.euro. who.int/ data/assets/pdf file/0003/217164/OutbreakGuidelinesupdated.pdf

28. WHO. (2018, April). Rabies vaccines: WHO position paper. Weekly epidemiological record. 16:201-220. http://apps.who.int/iris/bitstream/handle/10665/272371/WER9316.pdf

29. Wiskott A. (1936). Familiarer, angeborener Morbus Werlhofii? Monatsschr Kinderheikld. 68:212-216.

\section{Сведения об авторах:}

Бегларян Степан Арутюнович - аспирант каф. детских инфекционных болезней и детской иммунологии НМАПО имени П.Л. Шупика.

Адрес: г. Киев, ул. Богатырская, 30; тел. +38 (044) 201-32-04.

Чернышова людмила Ивановна - Д.мед.Н., проф. каф. детских инфекционных болезней и детской иммунологии НМАПО имени П.Л. Шупика.

Адрес: г. Киев, ул. Богатырская, зо, тел. +38 (044) 201-32-04

Статья поступила в редакцию 21.07.2018, принята к печати 01.12.2018.

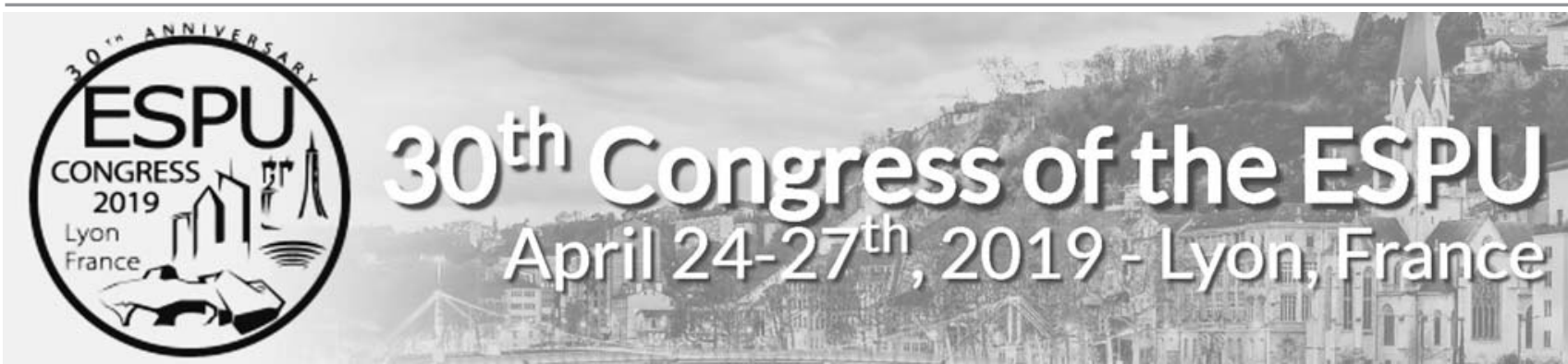

\section{Dear Colleagues and Friends!}

The European Society for Paediatric Urologists (ESPU) will celebrate its 30th anniversary in the International Congress Center of Lyon on April 24-27, 2019.

From a small gathering of friends in Rotterdam in 1989 to the largest world society of Paediatric Urology in 2019, a lot of work and energy have been spent by many experts from all around the world. This 30th anniversary will be a nice opportunity to thank the numerous contributors of this success story. This meeting will cover all fields of Paediatric Urology and we are expecting a strong attendance of experts from all the world including some famous stars of our specialy like Paul Mitrofanoff and Robert Whitaker who will receive the Honory Membership medal on that occasion.

Lyon is a great Roman city to stay and visit. It is the world capital of gastronomy and is wonderfully located between the Beaujolais and Burgundy in the North, and the Rhone Valley in the South. It was the capital of Gaule (27 BC) and is a UNESCO world heritage city. Walking through the middle age part is a delight with wonderful food, books and art markets, museums and shops. Lyon has a strong medical history with leading Hospitals and Universities. It is where the International Agency for Research on Cancer is. Lyon is close to the mountains and the sea. Its access is very easy by plane, train or car.

It is a pleasure and an honour for me to welcome you all as the local organizer of this meeting. It has a very special meaning for me as I was one of the co-founders of this Society 30 years ago, along with Roelof Scholmeijer, Rien Nijman, Jos de Vries and Patrick Duffy. The local organization is lead by Claude-Bernard University Congress Center and the overall organization is supervized by the ESPU team. Enjoy Lyon and its area and enjoy the scientific content of the 30th ESPU meeting.

Pierre Mouriquand, MD, FRCS(Eng), FEAPU

Professor and head of the Department of Paediatric Urology

Universite Claude-Bernard - Hospices Civils de Lyon

More information: https://congress2019.espu.org 


\title{
О.М. Мочульська, І.Б. Чорномидз, І.М. Горішний \\ Сучасна стратегія лікування атопічного дерматиту у дітей (огляд літератури)
}

\begin{abstract}
ДВНЗ «Тернопільський державний медичний університет імені І.Я. Горбачевського МОЗ України» SOVREMENNAYA PEDIATRIYA.2018.8(96):99-102; doi 10.15574/SP.2018.96.99

У структурі алергічних захворювань особливе місце посідає атопічний дерматит, оскільки він $є$ одним із найчастіших та перших проявів алергії, нерідко трансформується надалі в інші форми алергї̈, суттєво знижує якість життя дітей незалежно від віку, потребує тривалого, етапного лікування та реабілітації. Сучасна стратегія лікування атопічного дерматиту у дітей заснована на принципах доказової медицини, узагальнена у висновках II Міжнародної об'єднаної конференції з атопічного дерматиту (International Consensus Conference on Atopic Dermatitis, ICCAD). 3 метою уніфікації різних підходів до діагностики та лікування атопічного дерматиту Європейська академія алергології і клінічної імунології (European Academy of Allergy and Clinical Immunology, EAACl) разом з Американською академією алергії, астми і імунології (American Academy of Allergy, Asthma \& Immunology, AAAAI) створили робочу групу PRACTALL (Practical Allergology Consensus Report). Лікування атопічного дерматиту складається 3: контролю за довкіллям з усуненням алергенних та неалергенних факторів; лікувально-косметичного догляду за шкірою; системної і місцевої фрармакотерапії; лікування супутніх захворювань; навчання пацієнтів; реабілітації і профілактики. Системна фармакотерапія передбачає застосування лікарських засобів таких груп: антигістамінні, мембраностабілізуючі (кромони), антагоністи лейкотрієнових рецепторів, анти-IgE препарати, глюкокортикостероїди, седативні, фрерменти, сорбенти, гепатопротектори, пробіотики, антиоксиданти, антибактеріальні та протигрибкові, імуномодулюючі та імуносупресивні препарати.
\end{abstract}

Ключові слова: діти, атопічний дерматит, глюкокортикостероїди, антигістаміни, кромони.

\section{Clinical efficacy and immunomodulatory effect of allergen-specific immunotherapy with prolonged course of probiotics at atopic dermatitis in children O.M. Mochulska, I.B. Chornomydz, I.M. Horishnyi}

SHEE «Ternopil State Medical University named after I. Ya. Horbachevsky of Ministry of Healthcare in Ukraine»

Atopic dermatitis is particular in the structure of allergic diseases as it is one of the most prevalent and very first allergic manifestations, often transforming into other allergic forms, decreasing children's life quality independent of the age and requiring long, step-by-step treatment and follow-up care. The modern strategy for the treatment of atopic dermatitis in children is based on the principles of evidence-based medicine, summarized in the conclusions of International Consensus Conference on Atopic Dermatitis II (ICCAD). In order to unify different approaches to the diagnosis and treatment of atopic dermatitis, the European Academy of Allergology and Clinical Immunology (European Academy of Allergy and Clinical Immunology, EAACI) together with the American Academy of Allergy, Asthma and Immunology (American Academy of Allergy, Asthma \& Immunology, AAAAl) created a working group PRACTALL (Practical Allergology Consensus Report). Treatment of atopic dermatitis consists of: control of the environment to eliminate allergenic and non-allergenic factors; medical-cosmetic skin care; systemic and local pharmacotherapy; treatment of concomitant diseases; patient education; rehabilitation and prevention. Systemic pharmacotherapy includes using drugs of the following groups: antihistamines, membrane's stabilizators (kromons), leukotriene receptor antagonists, anti-lgE, glucocorticosteroids, sedative medications, enzymes, sorbents, hepatoprotectors, probiotics, antioxidants, antibacterial and antifungal, immunomodulatory and immunosuppressive drugs.

Key words: atopic dermatitis, glucocorticosteroids, antihistamines, membrane stabilizing (kromons), antagonists of leukotriene receptors, anti-IgE drugs.

\section{Современная стратегия лечения атопического дерматита у детей (обзор литературы) \\ О.Н. Мочульская, И.Б. Чорномидз, И.М. Горишный}

ГВУЗ «Тернопольский государственный медицинский университет имени И.Я. Горбачевского МЗ Украины»

В структуре аллергических заболеваний особое место занимает атопический дерматит, поскольку он является одним из наиболее частых и первых проявлений аллергии, нередко трансформируется в дальнейшем в другие формы аллергии, существенно снижает качество жизни детей независимо от возраста, требует длительного, этапного лечения и реабилитации. Современная стратегия лечения атопического дерматита у детей основана на принципах доказательной медицины и обобщена в выводах II Международной объединенной конференции по атопическому дерматиту (International Consensus Conference on Atopic Dermatitis, ICCAD). С целью унификации различных подходов к диагностике и лечению атопического дерматита Европейская академия аллергологии и клинической иммунологии (European Academy of Allergy and Clinical Immunology, EAACI) вместе с Американской академией аллергии, астмы и иммунологии (American Academy of Allergy, Asthma \& Immunology, AAAAl) создали рабочую группу PRACTALL (Practical Allergology Consensus Report). Лечение атопического дерматита состоит из: контроля за окружающей средой с устранением аллергенных и неаллергенных факторов; лечебно-косметического ухода за кожей; фармакотерапии системной и местной; лечения сопутствующих заболеваний; обучения пациентов; реабилитации и профилактики. Системная фрармакотерапия предусматривает применение лекарственных средств следующих групп: антигистаминные, мембраностабилизирующие (кромоны), антагонисты лейкотриеновых рецепторов, анти-IgЕ препараты, глюкокортикостероиды, седативные, ферменты, сорбенты, гепатопротекторы, пробиотики, антиоксиданты, антибактериальные и противогрибковые, иммуномодулирующие и иммуносупрессивные препараты.

Ключевые слова: дети, атопический дерматит, глюкокортикостероиды, антигистамины, кромоны.

3 а інформацією Всесвітньої організації Оххорони здоров'я (ВООЗ), кожен п'ятий житель Землі страждає від алергічних чи псевдоалергічних реакцій, в Україні вона виявляється майже в кожної четвертої дитини [6,7,11,24]. Усе частіше спостерігається полівалентна сенсибілізація, алергія стає поліорганною [2,9]. Уже зараз кожні 10 років поширеність алергічних захворювань збільшується у 2-3 рази. До цих захворювань належать бронхіальна астма (БА), алергічний риніт (АР), алергічний кон'юнктивіт (АК), атопічний дерматит (АД) і кропив'янка, медикаментозна і харчова алергія (XА), алергія на укуси комах, анафілаксія, ангіоневротичний набряк $[8,13]$. У структурі алергічних захворювань особливе місце посідає АД [2,11,15,28], оскільки він: $є$ одним із найчастіших та перших проявів алер- 
гіі; нерідко трансформується надалі в інші форми алергіï; суттєво знижує якість життя дітей незалежно від віку; потребує тривалого та етапного лікування й реабілітації [5,6,9,17]. Водночас багато питань залишаються не вивченими та дискусійними, зберігаються труднощі при визначенні лікувальної тактики хворих на АД.

Сучасна стратегія лікування АД у дітей заснована на принципах доказової медицини, узагальнена у висновках II Міжнародної об'єднаної конференції з АД (International Consensus Conference on Atopic Dermatitis, ICCAD) [7]. 3 метою уніфікації різних підходів до діагностики та лікування АД Європейська академія алергологї і клінічної імунології (European Academy of Allergy and Clinical Immunology, EAACI) разом 3 Американською академією алергії, астми та імунології (American Academy of Allergy, Asthma \& Immunology, AAAAI) створили робочу групу PRACTALL (Practical Allergology Consensus Report) [3,7,10,20]. Мета терапії АД: усунення або зменшення виразності симптомів захворювання; забезпечення тривалого контролю над захворюванням шляхом запобігання загостренням або зниженню їх важкості; зміна природного перебігу захворювання, попередження розвитку важких форм захворювання, які призводять до зниження якості життя хворого та інвалідизації; запобігання прогресуванню атопічного маршу; лікування супутніх захворювань [2,6,7,15,20,27].

Розроблена ступінчаста терапія АД. За рекомендаціями ICCAD, EAACI, AAAAI, PRACTALL вибір того чи іншого методу терапії залежить від важкості АД [3,7,10,19,22]:

а) на I сходинці (тільки сухість шкіри) застосовуються зволожувальні та пом'якшувальні засоби, елімінація тригерів;

б) на II сходинці (легкі або помірні симптоми АД) використовуються топічні глюкокортикостероїди (ГКС) низької або середньої активності та/або інгібітори кальциневрину;

в) на III сходинці (помірні або виразні симптоми АД) застосовуються топічні ГКС середньої або високої активності та при стабілізації процесу - топічні інгібітори кальциневрину (ТІК);

г) на IV сходинці (важкий АД, що не піддається лікуванню) використовуються системні імуносупресори та фототерапія.

При цьому антигістамінні препарати (АГП) також належать до базисних засобів лікування АД [3,9,10,19,22]. Але слід додати, що на перший план у комплексному лікуванні АД виве- дені не етіотропні, а патогенетичні та симптоматичні методи терапії даного захворювання $[6,7,16,18]$.

Поетапне лікування АД включає [2,3,7,10]:

- 1-й етап - елімінація причинних алергенів;

- 2-й етап - ліквідація загострення;

- 3-й етап - базисна терапія;

- 4-й етап - після досягнення клінічної ремісії проведення алергенспецифічної імунотерапії (АCIT) причинно-значущими алергенами $[1,27,28]$.

Лікування АД складається з: контролю за довкіллям з усуненням алергенних та неалергенних факторів; лікувально-косметичного догляду за шкірою; фармакотерапії системної і місцевої; лікування супутніх захворювань; навчання пацієнтів; реабілітації і профілактики [2,4,9,10,14,17].

Найефективнішою, безперечно, є етіотропна, елімінаційна терапія, спрямована на усунення контакту з алергенами різного походження та факторами, що спричиняють загострення захворювання. Методами його реалізації є: індивідуальна гіпоалергенна дієта з виключенням причинно-значущих алергенів; гіпоалергенні умови побуту, одягу, житла з метою виключення або зменшення контакту з інгаляційними і контактними алергенами; санація хронічних вогнищ інфекції; дегельмінтизація $[3,7,10,14,18]$.

Науковці одностайно наголошують на особливому значенні природного вигодовування для запобігання розвитку АД [2,6,8]. Разом з тим, результати останніх робіт доводять ефективність часткових білкових гідролізатів у складі замінників грудного молока у профілактиці АД у малюків групи високого ризику розвитку алергіi. Принцип індивідуального підбору, поступовості й почерговості повинен ретельно дотримуватися під час уведення всіх харчових продуктів [13].

Оскільки харчові алергени - вагомий тригерний фактор АД, дієтотерапія хворих із харчовою інтолерантністю є важливою складовою комплексного лікування хворих на АД і передбачає елімінаційні дієти. Дієтотерапія АД заснована на виключенні з харчування хворих продуктів-алергенів, а також продуктів-гістамінолібераторів [8,9]. Принципи лікувального харчування дітей з АД: виключення з харчування причинно-значущих алергенів і продуктів, які викликають перехресні реакцї; вилучення iз харчування продуктів, які мають високу сенсибілізаційну активність, облігатних алергенів; адекватна заміна продуктів, які були виключені, відповідно до вікових потреб дитини; 
«функціональне харчування» - використання продуктів, які сприяють нормалізації кишкового біоценозу, регуляції фізіологічних функцій організму, у тому числі імунної системи [3,7,10]. Проблема дієтотерапії АД є багатоплановою, вимагає індивідуального підходу, максимально повного виявлення непереносимості харчових продуктів і ретельного підбору раціону. Правильно побудована дієта не лише обмежує надходження в організм алергенів, але й має специфічний гіпосенсибілізаційний вплив і сприяє поліпшенню стану органів травлення, що, в свою чергу, підвищує толерантність організму до харчових алергенів $[2,8,13]$.

Поряд 3 раціональним харчуванням хворих на АД важливе значення має правильна організація побуту дитини і догляд за нею. Суттєве значення має створення сприятливого мікроклімату в помешканні, дотримання гіпоалергенних умов побуту, щоб усунути або мінімізувати контакти дитини з інгаляційними і контактними алергенами. Приміщення, у якому проживає дитина, необхідно часто провітрювати, двічі на день здійснювати вологе прибирання, різко обмежити кількість колекторів пилу, недопустиме утримання домашніх тварин, температура в приміщенні має бути в межах $20,0-22,0{ }^{\circ} \mathrm{C}$, вологість - 45,0-55,0\% [8,9,13,17].

Фармакотерапія АД включає використання зовнішньої та системної терапії [2,4,5,24]. Системна терапія передбачає застосування препаратів таких груп: антигістамінні (АГП), мембраностабілізуючі (кромони), антилейкотрієнові, анти-IgE препарати, глюкокортикостероїди (ГКС), седативні, ферменти, сорбенти, гепатопротектори, пробіотики, антибактеріальні та протигрибкові, імуномодулюючі та імуносупресивні препарати, антиоксиданти $[1,3,10,15,27,28]$.

Базисну терапію хворих на АД становлять АГП. Відомо три види рецепторів для гістаміну: Н1, Н2, Н3. АГП - основні патогенетичні препарати терапії при загостренні АД, ефект пов'язаний зі зворотною блокадою Н1-рецепторів за принципом конкуренції з природним гістаміном, що знижує виразність симптомів, обумовлених гістаміном (набряк, гіперемія, свербіж) [2,5,7,19,20]. АГП проявляють мембраностабілізуючу і протизапальну дію. У клінічній практиці застосовуються АГП 1-ї, 2-ї та 3-ї генерації $[3,8,10,12,22,26]$. Призначають АГП зазвичай курсами тривалістю 10-15 днів, повторними i/або зі зміною препаратів у разі потреби. Відмінністю АГП 1-ї гене- рації (діазолін, димедрол, перитол, піпольфен, супрастин, клемастин, фенкарол, тавегіл) $€$ ï легке проникнення через гематоенцефалічний бар'єр і антихолінергічна дія, що спричиняє седативний ефект. Показанням до їх застосування $є$ порушення сну у хворих з хронічним i/або безперервно-рецидивним перебігом АД, виразний свербіж шкіри [3,10,21,25]. АГП 2-ї генерації (терфенадин, лоратадин, цетиризин) не проникають через гематоенцефалічний бар'єр та не мають седативної діï, мають комбіновану протиалергічну і протизапальну дію, є високо-спорідненими до Н1-рецепторів, мають швидкий початок дії, тривалий терапевтичний ефект та не викликають розвитку тахіфілаксії. Для тривалого лікувального чи протирецидивного застосування раціональним $є$ вибір препаратів активних метаболітів 2-ї генерації [3,10,22]. АГП 3-ї генерації (левоцетиризин, фексофенадин, дезлоратадин) характеризуються набагато кращим профілем безпеки і є препаратами вибору за наявності супутніх алергічних захворювань - АР, АК i БА $[3,7,10,24,25]$.

$\mathrm{У}$ наш час досить часто в лікуванні АД використовують антимедіаторні препарати широкого спектра дії - мембраностабілізатори або кромони (кромоглікат натрію, недокромил натрію). Кромони стабілізують мембрани опасистих клітин і гальмують надходження іонів кальцію у клітини, внаслідок чого блокується розвиток алергічної реакції, зумовленої взаємодією антитіла з антигеном, а також усувають гемокоагуляційні порушення та порушення мікроциркуляції [3,9,10,19,21]. Мембраностабілізуючі препарати призначаються як у комплексі з основними методами лікування, так і в якості профілактичного лікування у реабілітаційному періоді на тривалий термін протягом кількох тижнів і навіть місяців $[1,5,7,12,22]$.

Антагоністи лейкотрієнових рецепторів (монтелукаст, зафірлукаст) призначають як системну монотерапію, так і у поєднанні з АГП, що посилює загальний протизапальний ефект лікування [5,12,22,24,25]. Антилейкотрієнові препарати є безпечними при тривалому лікуванні протягом декількох місяців і навіть років, зручними для щоденного застосування $[7,8,19]$.

За умов неефективності АГП при виразній гостроті й поширеності процесу застосовуються системні ГКС: дексаметазон, бетаметазон або метилпреднізолон [3,10,21,22,24]. Системні 
ГКС можуть використовуватися у разі важких рецидивів АД лише короткими курсами, що дозволяє швидко отримати клінічний ефект, але після цього необхідне повільне зниження дози до відміни засобу. Доведено значні переваги короткого курсу застосування системних ГКС, тоді як тривала терапія системними ГКС у загальнотерапевтичній практиці супроводжується численними побічними ефектами, такими як зниження мінеральної щільності кісток та остеопороз, гіпертензія, затримка росту дітей, надмірна маса тіла, катаракта, лімфопенія, бактеріальні та грибкові, вірусні інфекції, виразкові ураження травного каналу та зниження толерантності до глюкози $[1,7,8,19,21,23]$.

Цитостатичні засоби (циклоспорин А, азатіоприн) діють на транскрипцію генів, пригнічуючи проліферацію й активацію Т-лімфоцитів, проліферацію В-лімфоцитів і зниження активності NK-клітин [3,10]. Цитостатичні засоби застосовуються при хронічних важких випадках АД, резистентних до терапії [1].

Системна антибактеріальна, протигрибкова, противірусна терапія показана у разі ускладнення АД поширеною вторинною бактеріальною, грибковою чи вірусною інфекцією $[3,5,10,24]$. Слід уникати тривалого їх застосування з урахуванням можливої сенсибілізації до того чи іншого засобу $[6,19,23]$.

Важливим етапом лікування дітей з АД є корекція супутньої патології. У переважної більшості хворих на АД спостерігається супутня мультиорганна гастроентерологічна патологія, тобто у патологічний процес залучається не лише один орган травлення, але й суміжні печінка, підшлункова залоза, шлунок, кишечник. 3 метою їх лікування хворим слід призначати гепатопротектори (карсил, тіотриазолін), панкреатичні ферменти (фестал, креон, мезим, ензистал, дигестал), пробіотики (лінекс, біфіформ, лактовіт, хілак, ацидолак), ентеросорбенти (активоване вугілля, сорбекс, ентеросгель) [3,5,7,10,27].

Провідне місце займають порушення стану імунної системи при АД, тому показані імунокорегуючі засоби (плазмаферез, ACIT, тимопентин, рекомбінантний інтерферон, пімекролімус/такролімус, циклоспорин А) [1,3,10].

Необхідним елементом комплексної терапії хворих на АД є відновлення функціонального стану центральної і вегетативної нервової системи. У дітей часто порушується сон, спостерігаються напади нестерпного свербежу, змінюється поведінка, іноді розвиваються невротичні реакції і формуються психопатологічні риси особистості [2,5,23]. Певне місце у терапії займають седативні засоби (гліцесед, ноотропіл, енцефабол, пантогам, мазепам, феназепам) і фітотерапевтичні засоби седативної дії (валеріана, м'ята, собача кропива, меліса). Як антиоксиданти і мембрано-стабілізатори показані вітаміни, особливо А, Е, групи $\mathrm{B}, \mathrm{D}$, мікроелементи [3,5,10].

Сучасна системна фармакотерапія АД повинна бути етіопатогенетичною і впливати на механізми формування алергічного запалення, тому проблема її вивчення та удосконалення методик лікування АД у дітей ще довго не втрачатиме актуальності.

\section{ЛITEРАТУРА}

1. Балаболкин ИИ, Булгакова ВА, Елисеева ТИ. (2017). Атопический дерматит у детей: иммунологические аспекты патогенеза и терапии. Педиатрия. 2:128-131.

2. Беш ЛВ. (2017). Атопічний дерматит у дітей: що сьогодні потрібно знати педіатрам? Здоров'я України. 7(404):20-21.

3. Міністерство охорони здоров'я України (2012). Адаптовані клінічні настанови з діагностики, профілактики та лікування атопічного дерматиту.Київ:76.

4. Мочульська ОМ. (2017). Порівняльна характеристика клінічної ефективності різних схем лікування атопічного дерматиту у дітей, особливості застосування специфічної індукції імунологічної толерантності. Актуальні питання педіатрії, акушерства та гінекології. 1:5-11.

5. Невозинская ЗА, Плиева КТ, Корсунская ИМ. (2016). Возможности контроля над течением атопического дерматита. Consilium Mediсuт. Дерматология. 1:49-53.

6. Охотнікова ОМ, Яковлева НЮ, Черниш ЮР. (2016). Сучасні аспекти зовнішньої протизапальної терапії атопічного дерматиту у дітей. Современная педиатрия. 2:92-99.

7. Самцов $\mathrm{AB}$, Соколовский $\mathrm{EB}$, Аравийская ЕА. (2015). Рекомендации по лечению атопического дерматита (атопической экземы) Американской академии дерматологии, Европейской академии дерматовенерологии и Российского общества дерматовенерологов и косметологов. Мнение экспертов. Вестник дерматологии и венерологии. 6:11-16.

8. Славянская ТА, Деркач ВВ. (2016). Стратегия лечения атопического дерматита: из прошлого в будущее. Аллергология и иммунология. $17 ; 1: 4-11$.

9. Тяжка ОВ. (2013, бер.). Атопічний дерматит у дітей. Здоров'я України. Тематичний номер:30-31.

10. Чоп'як ВВ, Калюжна ЛД, Степаненко ВІ та ін. (2016). Атопічний дерматит: адаптована клінічна настанова, заснована на доказах. Державний експертний центр МО3 України. Київ: 112.

11. Anto JM, Bousquet J, Akdis M et al. (2017). Mechanisms of the Development of Allergy (MeDALL): Introducing novel concepts in allergy phenotypes. Journal of Allergy and Clinical Immunology. 139;2: 388-399.

12. Chan S, Cornelius V, Chen T et al. (2017). Atopic Dermatitis Anti-lgE Paediatric Trial (ADAPT): the role of anti-lgE in severe 
paediatric eczema: study protocol for a randomised controlled trial. Trails. 18;1: 136.

13. Czarnowicki T, Krueger JG, Guttman-Yassky E. (2017). Novel concepts of prevention and treatment of atopic dermatitis through barrier and immune manipulations with implications for the atopic march. Journal of Allergy and Clinical Immunology. 139; 6: 1723-1734.

14. Danby SG, Chalmers J, Brown $\mathrm{K}$ et al. (2016). A functional mechanistic study of the effect of emollients on the structure and function of the skin barrier. British Journal of Dermatology. 175; 5: 1011-1019.

15. Drucker AM. (2017). Atopic dermatitis: Burden of illness, quality of life, and associated complications. Allergy \& Asthma Proceedings. $38 ; 1: 3-8$.

16. Edwards C. (2016). Measurements of structure and function of skin: emollient effects on atopic dermatitis. British Journal of Dermatology. 175;5: 868-869.

17. Furue M, Chiba T, Tsuji G. et al. (2017). Atopic dermatitis: immune deviation, barrier dysfunction, ige autoreactivity and new therapies. Allergology International. 66; 3: 398-403.

18. Gittler JK, Wang JF, Orlow SJ. (2017). Bathing and associated treatments in atopic dermatitis. American Journal of Clinical Dermatology. 18;1:45-57.

19. Heratizadeh A, Werfel T. (2016). Anti-inflammatory therapies in atopic dermatitis. Allergy. 71;12:1666-1675.
20. Jonathan I Silverberg, Silverberg N. (2017). Atopic Dermatitis, an Issue of Dermatologic Clinics. Elsevier. Health Science Division. 35: 33.

21. Kamata $Y$, Tominaga M, Takamori M. (2016). Itch in atopic dermatitis management. Current Problems in Dermatology.50: 86-93.

22. Kido-Nakahara M, Furue M, Ulzii $D$ et al. (2017). Itch in atopic dermatitis. Immunology and Allergy Clinics of North America. $37 ; 1: 113-122$

23. Kim JP, Chao LX, Simpson EL, Silverberg Jl. (2016). Persistence of atopic dermatitis (AD): A systematic review and meta-analysis Journal of the American Academy of Dermatologyol. 75;4:681-687.

24. Lee GB, Fonacier L. (2017). Difficult to manage atopic dermatitis. Journal of Allergy and Clinical Immunology: in Practice. 5;1: 207-208.

25. Metz M, Staubach P. (2016). Itch management: topical agents. Current Problems in Dermatology.50: 40-45.

26. Ohtsu H, Seike M. (2017). Histamine and histamine receptors in allergic dermatitis. Handbook of Experimental Pharmacology. 241: 333-345.

27. Silverberg NB, Duran-McKinster C. (2017). Special Considerations for Therapy of Pediatric Atopic Dermatitis. Dermatologic Clinics. 35;3: 351-363.

28. Wert AF, Posa D, Tsilochristou O, Schwerk N. (2016). Treatment of allergic children - where is the progress (for the practicing allergist)? Pediatric Allergy and Immunology. 27; 7: 671-681.

\section{Сведения об авторах:}

Мочульская Оксана Николаевна - к.мед.н, ассистент каф. детских болезней с детской хирургией Тернопольского ГМУ имени И.Я. Горбачевского МЗ Украины. Адрес: г. Тернополь, Майдан Воли, 1; тел. (0352) 52-44-92.

Чорномидз Ирина Богдановна - к.мед.н, доц. каф. детских болезней с детской хирургией Тернопольского ГМУ имени И.Я. Горбачевского МЗ Украины. Адрес: г. Тернополь, Майдан Воли, 1; тел. (0352) 52-44-92.

Горишный Игорь Мирославович - к.мед.н, доц. каф. детских болезней с детской хирургией Тернопольского ГМУ имени И.Я. Горбачевского МЗ Украины. Адрес: г. Тернополь, Майдан Воли, 1 ; тел. (0352) 52-44-92.

Статья поступила в редакцию 13.06.2018, принята к печати 26.11.2018.

\section{ВНИМАНИЕ!}

Подписку журнала (с курьерской доставкой) можно оформить на сайте подписного агентства «АC-Медиа» web: www.smartpress.com.ua/ или по тел. 044-353-88-16, 044-500-05-06 - отдел продаж. Подписной индекс журнала «СОВРЕМЕННАЯ ПЕДИАТРИЯ» - $\mathbf{0 9 8 5 0}$ 


\title{
Л.В. Квашніна, В.П. Чернишов, І.М. Матвієнко, Т.Б. Ігнатова, Д.В. Осипчук Вплив лікарського засобу «Резістол ${ }^{\circledR}$ на гуморальний та клітинний імунітет дітей з рекурентними та гострими вірусними респіраторними захворюваннями: результати дослідження
}

ДУ «Інститут педіатрії, акушерства і гінекології імені академіка О.М. Лук'янової НАМН України», м. Київ

SOVREMENNAYA PEDIATRIYA.2018.8(96):104-112; doi 10.15574/SP.2018.96.104

\begin{abstract}
NK-лімфоцити (natural killers) є основними ефекторами природженого імунітету у подоланні вірусних інфекцій: вони беруть участь в імунному захисті, безпосередньо елімінують вірусінфіковані та злоякісно трансфоормовані клітини, активують інші клітини імунної системи завдяки секреції цитокінів. Стимуляція TLRs, зокрема TLR3, що експресуються майже на всіх NK-лімфоцитах, активує ̈̈х, що і призводить до секреції цитокінів, IФH- $\gamma$ та підвищення клітинного лізису вірусінфікованих і пухлинних клітин. Тобто розпізнавання вірусів через TLR3 допомагає NK-клітинам відігравати фундаментальну роль у першій лінії захисту організму проти вірусних інфекцій.

Результати науково-дослідної роботи 3 вивчення впливу лікарського засобу «Резістол»» на активність імунного захисту у дітей 3 ГРВІ та рекурентними інсекціями верхніх дихальних шляхів продемонстрували, що на тлі використанням «Резістол®» достовірно зростала кількість NK-клітин, які можуть безпосередньо розпізнавати вірусні патогени ( $($ <0,05). Водночас у групі дітей з ГРВI, яким не застосовувався ЛЗ «Резістол®», не відбувалося достовірних змін відсоткового вмісту в перифреричній крові активованих NK-клітин. У групі дітей з ГРВІ, у яких застосовувався Л3 «Резістол ${ }^{\oplus}$, спостерігались достовірно вищі абсолютні показники лейкоцитів та лімфоцитів порівняно з групою дітей, у яких «РезістолФ» не застосовувався $(\mathrm{p}<0,05)$, тоді як на початку лікування та спостереження дані показники не мали статистичних відмінностей між групами $(p>0,05)$. Ключові слова: діти, гуморальний імунітет, клітинний імунітет, гостра респіраторна вірусна інфекція, рекурентні інфекції, Pelargonium Sidoides, Л3 «Резістол $\oplus^{\oplus}$
\end{abstract}

\section{Influence of Resistol ${ }^{\circledR}$ Drug on Humoral and Cellular Immunity of Children with Recurrent and Acute Viral Respiratory Diseases: Research Findings \\ L.V. Kvashnina, V.P. Chernyshov, I.M. Matvienko, T.B. Ignatova, D.V. Osypchuk \\ State Institution «Institute of Pediatrics, Obstetrics and Gynecology named \\ after Academician O.M. Lukyanova, National Academy of Medical Sciences of Ukraine», Kyiv}

NK-lymphocytes (natural killers) are the main innate immunity effectors in overcoming viral infections: they participate in the immune defense, directly eliminate virus-infected and malignantly transformed cells, activate other cells of the immune system through the secretion of cytokines. Stimulation of TLRs, and TLR3 in particular, which are expressed in almost all NK-lymphocytes, activates them, leading to secretion of cytokines, IFN-?, and increased cellular lysis of virus-infected and tumor cells. That is, recognition of viruses through TLR3 helps NK cells play a crucial role in the first line of organism protection against viral infections.

The results of the research on the influence of the medicinal product «Resistol ${ }^{{ }}$» on the immune defense activity in children with ARVI and recurrent upper respiratory tract infections demonstrated that on the background of «Resisto ${ }^{\oplus}$ » use the number of NK cells that could directly recognize viral pathogens increased $(p<0.05)$. At the same time, in the group of children with acute respiratory viral infections, who did not use Rezistol ${ }^{\circledR}$, there was no significant change in the percentage of activated NK cells in peripheral blood. In the group of children with acute respiratory infections who used Resistol ${ }^{\oplus}$, significantly higher absolute values of leukocytes and lymphocytes were registered as compared with the group of children in whom Resistol ${ }^{\circledast}$ was not used $(p<0.05)$, whereas at the beginning of treatment and observation these data did not differ statistically between the groups $(p>0.05)$.

Key words: children, humoral immunity, cellular immunity, acute respiratory viral infection, recurrent infections, Pelargonium Sidoides, Resistol ${ }^{\circledR}$.

\section{Влияние лекарственного средства «Резистол» на гуморальный и клеточный иммунитет детей з рекуррентными и острыми вирусными респираторными заболеваниями: результаты исследования \\ Л.В. Квашнина, В.П. Чернышев, И.Н. Матвиенко, Т.Б. Игнатова, Д.В. Осипчук \\ ГУ «Институт педиатрии, акушерства и гинекологии имени академика Е.М. Лукьяновой НАМН Украины», г. Киев}

NK-лимфоциты (natural killers) являются основными эффекторами врожденного иммунитета в борьбе с вирусными инфекциями: они принимают участие в иммунной защите, непосредственно элиминируют вирусинсицированные и злокачественно трансформированные клетки, активируют другие клетки иммунной системы благодаря синтезу цитокинов. Стимуляция TLRs, в частности TLR3, которые експрессируются практически на всех NK-лимфоцитах, активирует их, что и приводит к секреции цитокинов, ИФН- $\gamma$ и повышению лизиса вирусинфицированных и опухолевых клеток. То есть распознавание вирусов через TLR3 помогает NK-клеткам играть фундаментальную роль в первой линии защиты организма против вирусных инфекций.

Результаты научно-исследовательской работы по изучению влияния препарата «Резистол» на активность иммунной защиты у детей с ОРви и рекуррентными инфекциями верхних дыхательных путей продемонстрировали, что на фоне приема ЛС «Резистол» достоверно увеличивалось количество NK-клеток, которые могут непосредственно распознавать вирусы $(p<0,05)$. В то же время в группе детей с ОРВИ, которым не применяли «Резистол», не происходило достоверных изменений процентного содержания в периферической крови активированных NК-клеток. В группе детей с ОРВИ, которых лечили препаратом «Резистол», наблюдались достоверно более высокие абсолютные показатели лейкоцитов и лимфоцитов по сравнению с группой детей, у которых «Резистол» не применялся (р<0,05), в то время как в начале исследования данные показатели не имели статистических различий между группами $(p>0,05)$.

Ключевые слова: дети, гуморальный иммунитет, клеточный иммунитет, острая респираторная вирусная инфекция, рекуррентные инфекции. Pelargonium Sidoides, Резистол. 


\section{Вступ}

$\mathrm{H}$ езважаючи на достатню кількість впроваджених клінічних протоколів та настанов, ситуація щодо інфекційної захворюваності дітей у світі протягом останніх років не покращується: інфекції дихальних шляхів посідають третє місце у структурі смертності в усіх вікових та гендерних групах, поступаючись тільки серцево-судинним та цереброваскулярним захворюванням, а в світі щорічно витрачається біля 35 млн доларів на вирішення проблем, пов'язаних з інфекціями дихальних шляхів (госпіталізація, смертність, інвалідизація) [3]. В Україні щорічно на гострі респіраторні вірусні інфекції (ГРВІ) хворіє біля 6 млн населення, i найбільшу кількість захворілих становлять діти. За даними літератури, постійні виділення 3 носових ходів, довготривалий кашель, відсутність ефекту від стандартної терапії зустрічаються у 25-40\% дітей дошкільного та молодшого шкільного віку переважно в осінньо-весняний період року [3] на тлі зростання резистентності вірусів до певних груп лікарських засобів (противірусні препарати). Саме тому тривають пошуки методів та ліків, які не тільки зменшать важкість перебігу респіраторних інфекцій, але й дадуть змогу організму дитини підвищити опірність до збудників захворювання.

Одним 3 альтернативних медикаментів може бути рослинний препарат, виготовлений 3 кореня Pelargonium Sidoides. Цей лікарський засіб (ЛЗ) рослинного походження широко використовується в Німеччині, Великобританіï, Туреччині, Бразиліі, країнах Балтики для лікування гострих інфекцій дихальних шляхів [17] та 3 метою профілактики в групі дітей 3 рекурентними респіраторними інфекціями. Екстракт містить первинні поліфеноли (катехін та галлокатехін, продельфінідин), протеїни, мінерали, а також, у менших концентраціях, похідні 7-кумарину (включаючи умкалін) [17], які відрізняються за структурою від добре відомого антикоагулянта кумарину, та ніяк не пов'язані 3 антикоагулянтною активністю або взаємодією з варфарином [14]. За рахунок своїх біологічно активних компонентів екстракт Pelargonium Sidoides має мультифакторну дію, що включає противірусну та помірну антибактеріальну дію [7,8,13,15,16]. Дослідження in vitro продемонстрували здатність екстракту активувати протипухлинний фактор $(\alpha-\mathrm{TNF})$, стимулювати продукцію $\beta$-інтерферону та підвищувати активність натуральних клітин-кілерів (NK); під дією екстракту покращувався фагоцитоз та пригнічувалась адгезія збудника до клітин епітелію.

Екстракт Pelargonium Sidoides також продемонстрував клінічну ефективність у зменшенні важкості та тривалості перебігу інфекцій верхніх дихальних шляхів (ВДШ) - бронхіт, риносинусит, тонзилофарингіт. Метааналіз 2008 року (Cochrane Review), який містить результати лікування 3800 пацієнтів у сліпому плацебо-контрольованому РКД та 5400 пацієнтів у неінтервенційному відкритому дослідженні (пацієнти віком від 1 року життя), продемонстрував ефективність та безпеку екстракту.

Дослідження, проведені співробітниками ДУ «ІПАГ імені академіка О.М. Лук'янової НАМН України» [1], продемонстрували високу клінічну ефективність екстракту Pelargonium Sidoides (Л3 «Резістол ${ }^{\circledR} »$, краплі оральні, виробництва ПАТ «Галичфарм», Україна) у веденні дітей з гострими бронхітами та риносинуситами, а також високу активність щодо підвищення рівнів sIgA, який відіграє найбільшу роль у захисті респіраторного тракту та легень від проникнення збудників у тканини шляхом аглютинації мікроорганізмів та нейтралізації токсинів, інгібує зв'язування вірусів та бактерій з поверхнею слизових оболонок та блокує реплікацію збудника [4,21,22] (табл.1).

Таблиия 1

Концентрація імунних факторів у слині дітей с гострим респіраторним захворюванням до і після прийому ЛЗ “Резістол” [1]

\begin{tabular}{|l|c|c|c|}
\hline $\begin{array}{r}\text { Група дітей } \\
(\mathbf{n}=15)\end{array}$ & $\begin{array}{c}\text { До } \\
\text { Імунні } \\
\text { прийому л3 }\end{array}$ & $\begin{array}{c}\text { Пгосля } \\
\text { прийому л3 }\end{array}$ & $\begin{array}{c}\text { Контрольні } \\
\text { показники }\end{array}$ \\
\hline slgA & $0,16 \pm 0,01^{* *}$ & $0,40 \pm 0,02^{*}$ & $0,41 \pm 0,06$ \\
\hline $\operatorname{lgG}$ & $0,050 \pm 0,002$ & $0,080 \pm 0,002^{*}$ & $0,070 \pm 0,016$ \\
\hline $\lg \mathrm{A}$ & $0,05 \pm 0,01$ & $0,07 \pm 0,02$ & $0,05 \pm 0,01$ \\
\hline Лізоцим & $0,013 \pm 0,006$ & $0,010 \pm 0,001$ & $0,010 \pm 0,002$ \\
\hline
\end{tabular}

Примітка: * - різниця достовірна між показниками до та після прийому препарату (р<0,05); ** - різниця достовірна між показниками порівняно з контролем $(\mathrm{p}<0,05)$. 
Загалом дослідження, проведене в ДУ «ППАГ імені академіка О.М. Лук'янової НАМН України» [1], продемонструвало, що ЛЗ «Резістол ${ }^{\circledR} »$ сприяє не тільки регресії клінічної симптоматики, але й ерадикації патогенів, має виразні імуномодулюючі властивості та підвищуе неспецифічну резистентність організму. Також дослідження довело безпечність використання Л3 «Резістол ${ }^{\circledR} »$ у дітей - протягом курсу лікування не було зареєстровано жодного ускладнення. Ці результати повністю збігаються 3 результатами аналізу безпеки використання екстракту Pelargonium Sidoides в країнах Свропи: за період 1994-2006 рр. було реалізовано 304 млн щоденних доз EPs 7630, а частота ускладнень/побічних ефектів склала 0,53 випадку на 1000000 щоденних доз [18]. Це означає, що тільки 1 із 189000 пацієнтів мав побічну реакцію/ускладнення: 0,27/1000000 доз реакції гіперчутливості, 0,13/1000000 розлади шлунково-кишкового тракту, 0,05/1000000 кровотеча з ясен або носові кровотечі.

Отримані результати підтвердили, що Л3 «Резістол ${ }^{\circledR} »$ можна використовувати як 3 лікувальною, так і з профілактичною метою для стимуляції неспецифічної резистентності організму у дітей з рекурентними респіраторними інфекціями. 3 огляду на вищенаведене та отримані результати щодо наявності імуномодулюючого впливу ЛЗ «Резістол ${ }^{\circledR} »[1,4,7,13$,
16, 21,22], виникла необхідність поглибленого вивчення його противірусного ефекту через Toll-подібні рецептори 3 (англ. Toll-liked receptors).

\section{Ідея дослідження}

Toll-подібні рецептори (TLRs) - це клас клітинних рецепторів з одним трансмембранним доменом, які відіграють одну з ключових ролей у природженому імунітеті: саме вони розпізнають структури мікроорганізмів і активують проти них імунну відповідь. Загалом відомо 13 TLRs ссавців, що позначаються абревіатурами (TLR1 - TLR13), у людини існує 10 TLRs (TLR1 - TLR10) - саме вони зв'язують різні ліганди і представлені в організмі людини на різних типах клітин (моноцити, макрофаги, нейтрофіли, опасисті клітини, еозинофіли та ін.).

TLRs забезпечують ідентифікацію патогена iз подальшим включенням важливих компонентів спадкового імунітету, та відіграють вирішальну роль у ранньому захисті організму від чужорідних структур. Функціонуючи на зовнішній мембрані клітин, TLRs мають характерну властивість розпізнавати молекулярні структури мікроорганізмів (певні бактеріальні, вірусні чи грибкові), які отримали назву РАМР (pathogen-associated molecular patterns «структури, які пов'язані з патогеном») [10].

3 точки зору імунного захисту організму дитини, певний інтерес викликають TLR3 (рис. 1),

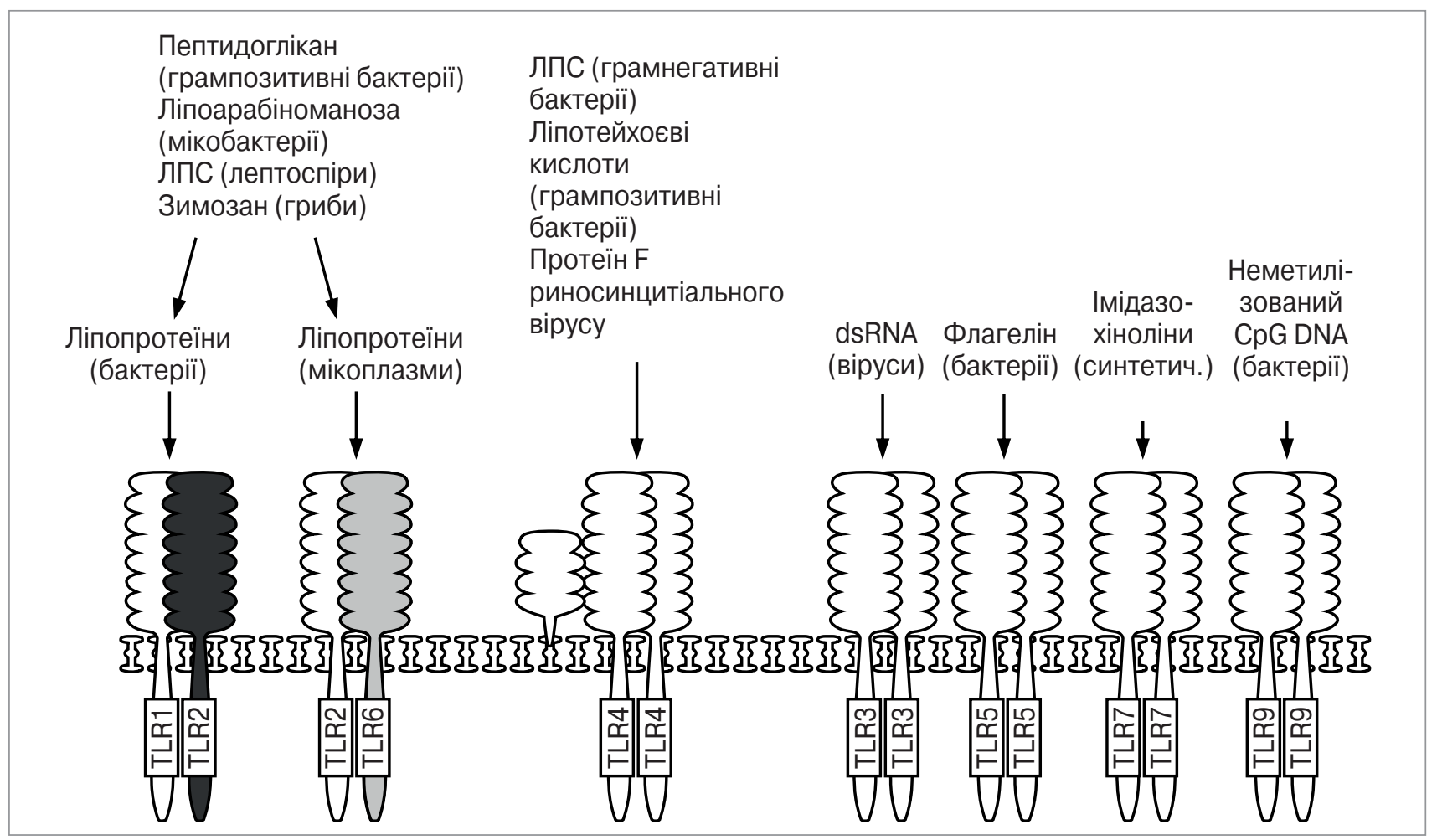

Pис.1. Лігандна специфрікація Toll-подібних рецепторів (TLR) за S. Janssens ta R.Beyaert, 2003 
Розподіл дітей на групи дослідження

\begin{tabular}{|c|c|c|c|c|}
\hline \multicolumn{2}{|c|}{ 1 група: } & \multicolumn{2}{c|}{ 2 група: } & $\begin{array}{c}\text { 3 група: } \\
\text { діти з ГРвІ }\end{array}$ \\
здорові діти
\end{tabular}

які «відповідають» саме за противірусний захист, мають внутрішньоклітинне розташування та діють через дендритні клітини та $\beta$-лімфоцити. TLR3 розпізнає та зв'язується з дволанцюговою РНК (длРНК), що є обов'язковим проміжним продуктом реплікації PHК-вмісних вірусів. Стимуляція TLRs активує NK-лімфоцити, що призводить до секреції цитокінів, підвищення клітинного лізису вірусінфікованих і пухлинних клітин $[6,11,19]$.

Відомо, що NK-лімфоцити є основними ефекторами природженого імунітету у подоланні вірусних інфекцій. Вони беруть участь в імунному захисті, безпосередньо елімінують вірусінфіковані та злоякісно трансформовані клітини та активують інші клітини імунної системи завдяки секреції цитокінів [20]. На NK-лімфоцитах людини експресуються майже всі TLR, зокрема TLR3. Доведено, що стимуляція NK-лімфоцитів синтетичним аналогом длРНК - poly I:C, який є лігандом TLR3, індукує секрецію IФН- $\gamma$ та низки інших прозапальних цитокінів, котрі є важливими регуляторами імунної відповіді. Також, у відповідь на стимуляцію TLR3, NK-клітини підвищують експресію маркера активації CD69 [5,12,23]. Тобто розпізнавання вірусів через TLR3 допомагає NK-клітинам відігравати фундаментальну роль у першій лінії захисту організму проти вірусних інфекцій. Саме наявність цього

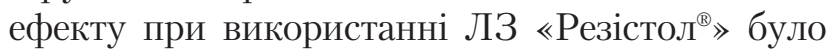
цікаво дослідити у дітей як з гострими, так і рекурентними респіраторними захворюваннями.

Мета і завдання науково-дослідної роботи

Головною метою даної дослідної роботи було вивчення впливу ЛЗ «Резістол ${ }^{\circledR} »$ на імунітет дітей з гострими та рекурентними респіраторними захворюваннями (стадія клінічного благополуччя) вікової групи $>1$ рік -7 років життя. Під час проведення роботи було заплановано:

- дослідити активаційну відповідь NK-клітин при стимуляції противірусного рецептора TLR3 за допомогою синтетичного аналога длРНК - poly I:C;

- дослідити процентне співвідношення NKклітин та Т-лімфоцитів;
- вивчити рівні прозапальних та протизапальних цитокінів (інтерлейкін 6 та інтерлейкін 8 - IL-6 та IL-8).

\section{Дизайн та повнота дослідження}

У дослідженні взяли участь 50 дітей вікової групи $>1$ року -7 років життя, які знаходились під наглядом у відділенні медичних проблем здорової дитини та преморбідних станів ДУ «ІПАГ імені академіка О.М. Лук'янової НАМН України» та були розподілені на три групи (табл. 1). Усі діти повністю завершили дослідження, тобто не було жодної дитини, яка б вибула з дослідження з будь-яких причин. Відповідно до етичних вимог, у 100\% випадків обома батьками було підписано форми інформованої згоди на участь дитини у дослідженні.

У групах дітей, які отримували ЛЗ «Резістол ${ }^{\circledR} \gg(20$ дітей $)$ протягом 21 дня послідовно (як з лікувальною, так і з профілактичною метою), було дотримано наступний режим дозування: 1-6 років: по 10 крапель 3 рази на добу; >6-7 років: по 20 крапель 3 рази на добу. Під час дослідження жодна дитина не приймала ЛЗ, крім симптоматичних (деконгестанти, сольові розчини для промивання носової порожнини, тепле пиття), що повністю відповідає основним рекомендаціям чинних клінічних протоколів, затверджених МОЗ України.

Усі діти 1 та 2 груп отримали повний спектр клінічних обстежень - три послідовні клінічні огляди: на початку дослідження, на 14-у добу дослідження, наприкінці дослідження (21 день).

Жодна досліджувана дитина не потребувала позапланового клінічного огляду у зв'язку 3 погіршенням стану або розвитком побічних/небажаних реакцій.

Усім дітям з гострими та рекурентними захворюваннями (40 дітей) двічі проводився забір венозної крові в об'ємі від 500 мкл до 2 мл (підготовленим медичним персоналом з дотриманням умов асептики) на початку та наприкінці (через 21 добу) виконання роботи для вивчення активаційної відповіді NK-клітин при стимуляції противірусного рецептора TLR3 за допомогою синтетичного аналога 
длРНК - poly I:C (Sigma-Aldrich, США) з дотриманням усіх вимог до зберігання та використання реактивів та обладнання (інкубатор Revco, Швейцарія; проточний цитометр FACScan Becton Dickinson, США).

Обробка отриманих результатів відбувалась за допомогою програмного забезпечення Cell Quest software (BD Biosciences, США). Під час проведення імунологічного дослідження зразків венозної крові визначались:

- абсолютні та відносні показники клітин крові (лейкоцити, лімфоцити, моноцити);

- рівні цитокінів (Interleukin-6 (IL-6); Interleukin-8 (IL-8));

- рівні активованих $\boldsymbol{C D 6 9}^{+} \mathrm{NK}-$-клітин:

- CD69 $^{+}$є маркером ранньої активації NK-клітин та універсальним маркером для використання in vitro у лабораторнофункціональних тестах: він має низьку щільність експресії на мембрані неактивованих клітин, швидко експресується на стимульованих лімфоцитах, що забезпечує безпосереднє вимірювання відповіді на стимул в експерименті, зменшуючи вплив будь-яких факторів. Експресія CD69 у відповідь на стимуляцію потребує транскрипції нових молекул РНК та синтезу протеїнів, є невід’ємною частиною активаційного процесу та відображає функціональноактивну субпопуляцію NK-клітин [5,9];

- відсотковий вміст $\mathrm{CD} 19^{+} \mathrm{CD} 3$ :

В-лімфоцити, які безпосередньо відповідають за продукцію антитіл;

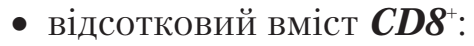

цитотоксичні Т-лімфоцити, які знищують інфіковані та злоякісно трансформовані клітини;

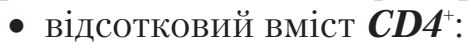

Т-лімфоцити, які переважно виконують імунорегулюючу функцію, регулюють продукцію антитіл та беруть участь у механізмах гіперчутливості [21].

Результати імунологічних досліджень у дітей з ГРВІ (1 група дітей)

У групі дітей з ГРВІ, які приймали Л3 «Резістол ${ }^{\circledR} \gg($ (група Іб), достовірно зростала $(\mathrm{p}<0,05)$ кількість NK-клітин, які можуть безпосередньо розпізнавати вірусні патогени (рис. 2). Натомість у групі дітей з ГРВІ, яким не застосову-

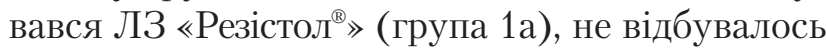
достовірних змін відсоткового вмісту в периферичній крові активованих NK-клітин.

У групі дітей з ГРВІ, які застосовували Л3 «Резістол ${ }^{\circledast} \gg$, при повторному обстеженні спостері-

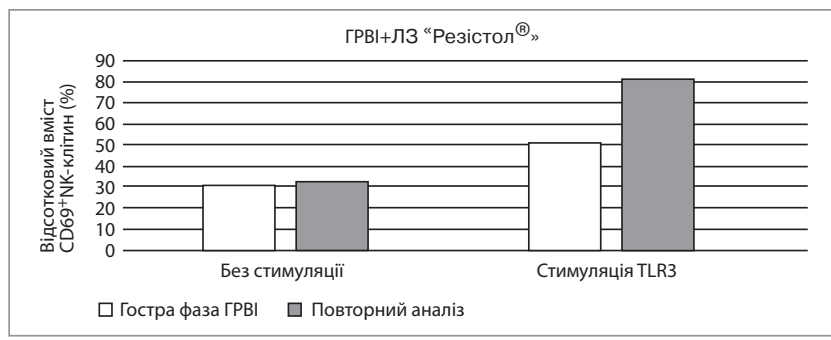

* $\mathrm{p}<0,05$ - порівняно 3 гострою фазою (початок захворювання).

Pис. 2. Зміна відсоткового вмісту активованих CD69+ NK-клітин у групі дітей з ГРВІ при застосуванні ЛЗ «Резістол ${ }^{\circledR}$ : «без стимуляції» - це показник, який відбиває відсотковий вміст у перифреричній крові активованих NK-клітин (тобто тих, що експресують маркер активації CD69); «стимуляція» - показник результату фуункціонального тесту, в основі якого лежить інкубація перифрерійної крові 3 агоністом TLR-3 — poly I:C та подальша оцінка відсоткового вмісту активованих NK-клітин (CD69+). Саме цей показник дає змогу оцінити функціональний противірусний потенціал NK-клітин, тобто здатність цих клітин активуватися при взаємодії через противірусний рецептор TLR3

гались достовірно вищі $(\mathrm{p}<0,05)$ абсолютні показники лейкоцитів та лімфоцитів порівняно з групою дітей, що не приймали ЛЗ (група Іа), тоді як на початку лікування та спостереження дані показники не мали статистичних відмінностей між групами $(\mathrm{p}>0,05)$ (рис. 3,4$)$.

Аналіз результатів дослідження концентрації сироваткових цитокінів IL-6 та IL-8 у групах дітей з ГРВІ (1а та 1б) не виявив достовірних відмінностей обраних показників у динаміці, як у групі Іб (рис. 5), так і в групі Іа (рис. 6).

Таким чином, можна стверджувати, що основні зміни в групах дітей з ГРВІ відбува-

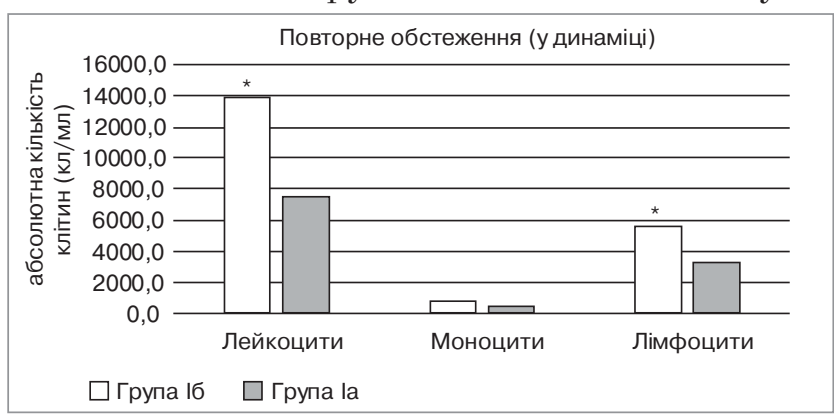

* $<00,05-$ у порівнянні між групами 1 а та 16

Pис. 3. Абсолютні значення імунних показників крові при повторному обстеженні (після 21-денного курсу лікування або спостереження)

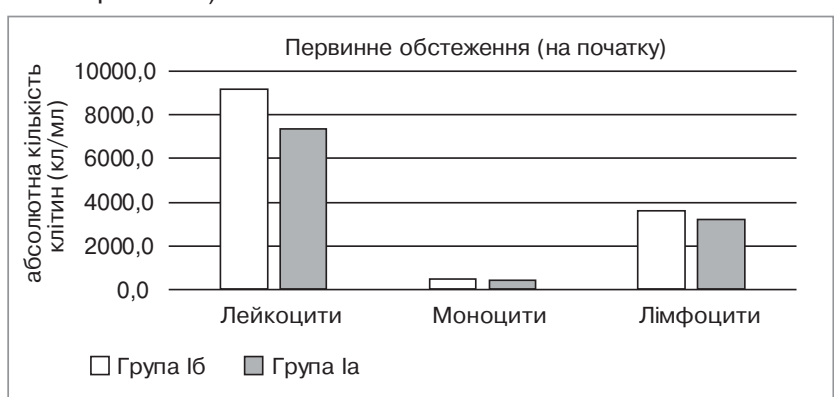

Pис. 4. Абсолютні значення імунних показників крові на початку дослідження ( $p>0,05$ у порівнянні між групами) 


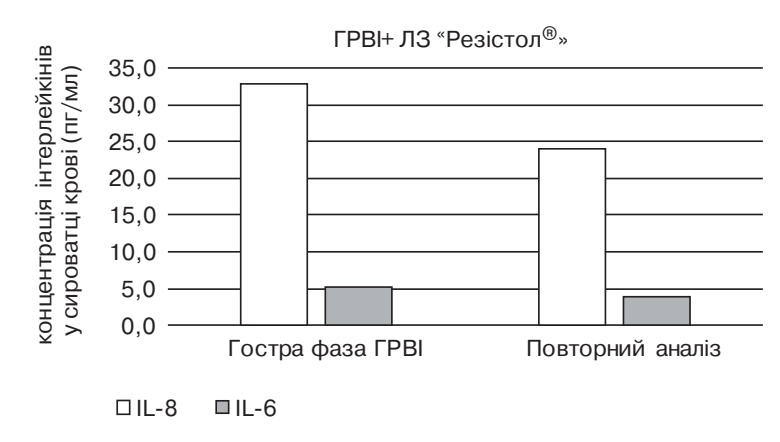

Pис. 5. Концентрації сироваткових цитокінів IL-8 та IL-6 у групі дітей з ГРВІ, які отримували ЛЗ «Резістол ${ }^{\circledast »}$ (група Іб)

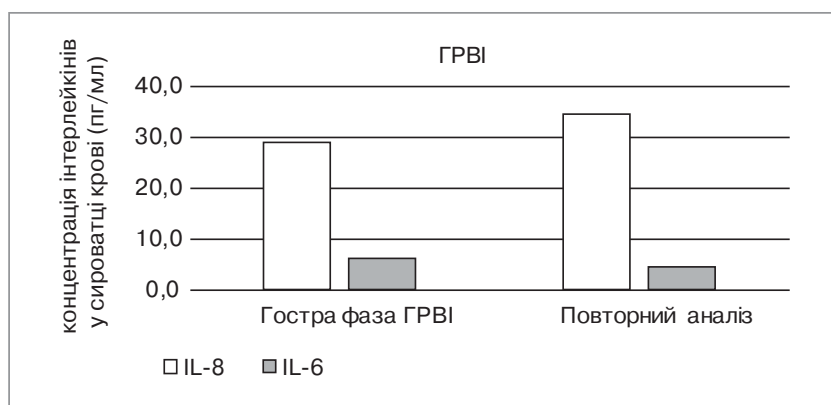

Pис. 6. Концентрації сироваткових цитокінів IL-8 та IL-6 у груп дітей з ГРВІ, які не отримували ЛЗ «Резістол ${ }^{\oplus »}$ (група Іа)

лись у показниках клітинного імунітету. У дітей, яким проводилось лікування ГРВІ з використанням ЛЗ «Резістол ${ }^{\circledR} »$ краплі оральні (ПАТ «Галичфарм», Україна), достовірно збільшувалась абсолютна кількість лейкоцитів за рахунок лімфоцитів - клітин, які переважно залучені до елімінації вірусних патогенів. Також у групі дітей з ГРВІ, які отримували ЛЗ «Резістол ${ }^{\circledR}$, достовірно зростала кількість NK-клітин, що здатні активуватись при стимуляції TLR3 (тобто здатні безпосередньо розпізнати вірусні патогени), що можна віднести до дії активних речовин ЛЗ «Резістол ${ }^{\circledR} »$.

Застосування ЛЗ «Резістол ${ }^{\circledR}$ » для профілактики рекурентних інфекцій

Респіраторні інфекції у світі займають перше місце серед усіх захворювань, 85\% цих інфекцій припадає на дитячий вік. До групи дітей з рекурентними інфекціями ВДШ зазвичай відносять дітей, які хворіють на повторні респіраторні інфекції протягом одного року (6-12 епізодів на рік, за даними різних авторів та настанов). Цікаво, що спроба знайти причину частих захворювань тільки в полі порушень з боку імунної системи виявилась не зовсім вдалою. У дітей із рекурентними інфекціями ВДШ дійсно частіше відзначалися знижені показники імунітету, проте різниця була несуттєвою - майже у половини дітей 3 рекурентними інфекціями імунологічні показники крові були в межах вікової норми або, навіть, підвищеними [2].

Як уже зазначалося, NK-лімфоцити є основними ефекторами природженого імунітету у подоланні вірусних інфекцій. Функціональний тест з оцінкою експресії $\boldsymbol{C D 6 9}$ на NK-клітинах відображає функціонально активну субпопуляцію цих клітин та є актуальним для аналізу не лише при ГРВI, але й в групах дітей 3 рекурентними інфекціями ВДШ для виявлення можливих порушень, що можуть лежати в основі підвищеної чутливості до збудників респіраторних інфекцій.

Враховуючи літературні дані щодо відсутності суттєвих відмінностей в імунологічних показниках між здоровими дітьми та дітьми 3 рекурентними інфекціями ВДШ, у якості додаткового контролю також досліджували функціональний стан ланки NK-клітин у групі здорових дітей для подальшого аналізу та порівняння цього параметра з групами дітей з рекурентними інфекціями ВДШ.

Порівняльний аналіз імунологічних досліджень показав, що в групі дітей з рекурентними інфекціями ВДШ, яким застосовували Л3 «Резістол ${ }^{\circledR} \gg($ група 2б), відсотковий вміст NK-клітин був достовірно вищим $(\mathrm{p}<0,05)$ при первинному аналізі порівняно 3 контрольною групою (група 3) (рис. 7).

Водночас відсоток NK-клітин 3 активаційним фенотипом був достовірно зниженим $(\mathrm{p}<0,05)$ при порівнянні з контрольною групою (рис. 8), як при первинному, так і при повторному аналізі. Такі дані можуть бути проявом компенсаторного механізму зниженої функціональності NK-клітин за рахунок зростання їх кількісного показника, який частково коригується після застосування ЛЗ «Резістол ${ }^{\circledR}$ » (рис. 7,8$)$ - простежується тенденція до зниження кількісного показника NK-клітин при одночасному зростанні відсотка клітин 3 активаційним фенотипом без стимуляції та достовірного зростання відсоткового вмісту NK-клітин, що здатні активуватись при стимуляції TLR3, порівняно з контролем (група 3) (рис. 8).

Для детальнішого розуміння імунологічних процесів, які відбувались у групах, було проведено аналіз імунологічних показників у динаміці. Дослідження показали, що в групі дітей 3 рекурентними інфекціями ВДШ, у якій 3 метою профілактики застосовували Л3 «Резістол ${ }^{\circledR}$ (група 2б), основні імунні показники залишались без достовірних змін (рис. 9). 


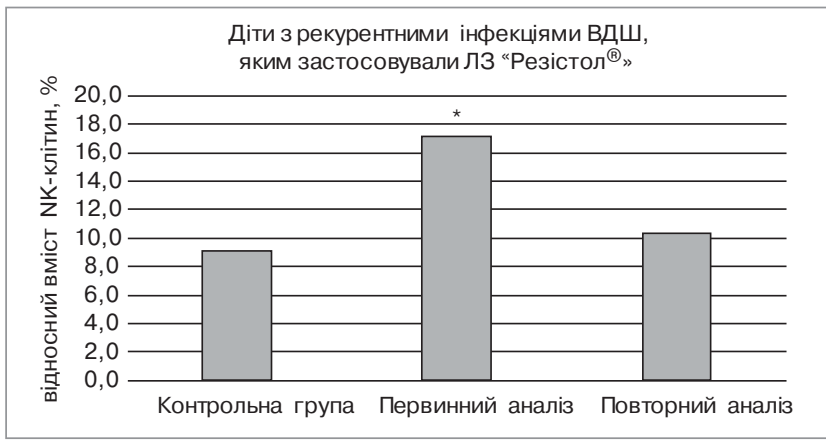

${ }^{*} \mathrm{p}<0,05$ - порівняно 3 контрольною групою

Pис. 7. Показники відсоткового вмісту NK-клітин (у динаміці) у дітей з рекурентними інфеекціями ВДШ, яким застосовували ЛЗ «Резістол ${ }^{\otimes}$ (група 2б) порівняно 3 контрольною групою (група 3)

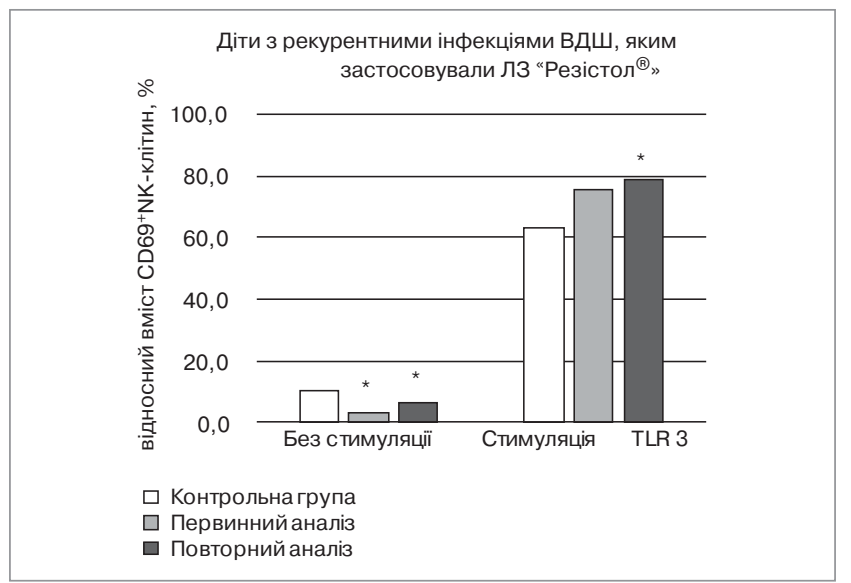

* $\mathrm{p}<0,05$ - порівняно з аналогічним показником у контрольній групі

Pис. 8. Зміни відсоткового вмісту активованих CD69+ NK-клітин у групі дітей 3 рекурентними інсекціями ВДШ, яким застосовували ЛЗ «Резістол ${ }^{\circledast n}$ (група 2б), порівняно 3 контрольною групою (група 3)

Проте у цій групі зростав відсотковий вміст активованих NK-клітин $\left(\mathrm{CD} 69^{+}\right)$після застосування ЛЗ «Резістол ${ }^{\circledR} »($ рис. 8).

У групі дітей 3 рекурентними інфекціями ВДШ, яким не призначали профілактично Резістол ${ }^{\oplus}$, дослідження виявило динаміку зниження відсотка NK-клітин порівняно з контрольною групою здорових дітей (група 3) (рис. 10) (різниця недостовірна, $\mathrm{p}>0,05$ ).

Проте, на відміну від групи дітей, яким призначали 3 профілактичною метою Резістол ${ }^{\circledR}$

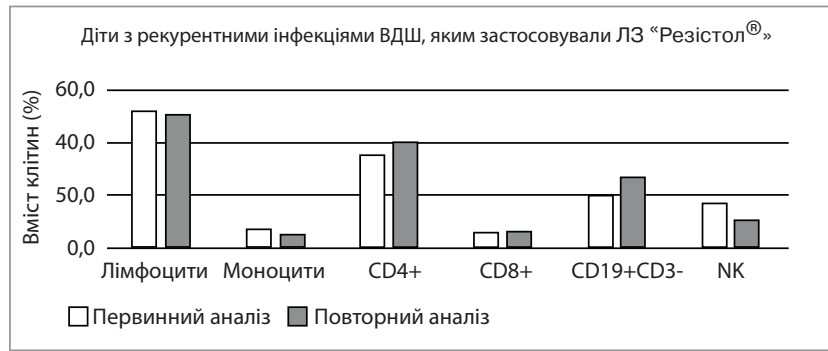

Pис. 9. Зміни імунологічних показників у групі дітей з рекурентними інфекціями ВДШ, яким застосовували ЛЗ «Резістол ${ }^{\circledR}$ (група 2б) з профрілактичною метою

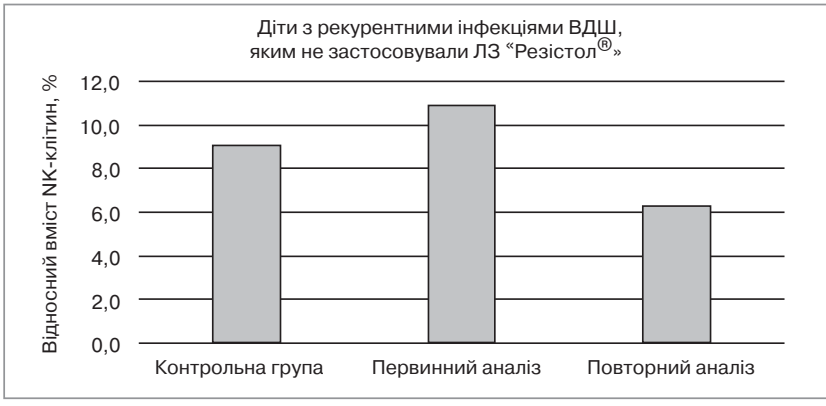

Pис. 10. Показники відсоткового вмісту NK-клітин (у динаміці) у дітей з рекурентними інфекціями ВДШ, яким не застосовували ЛЗ «Резістол ${ }^{\circledast »}$ (група 2а), порівняно 3 контрольною групою (група 3)

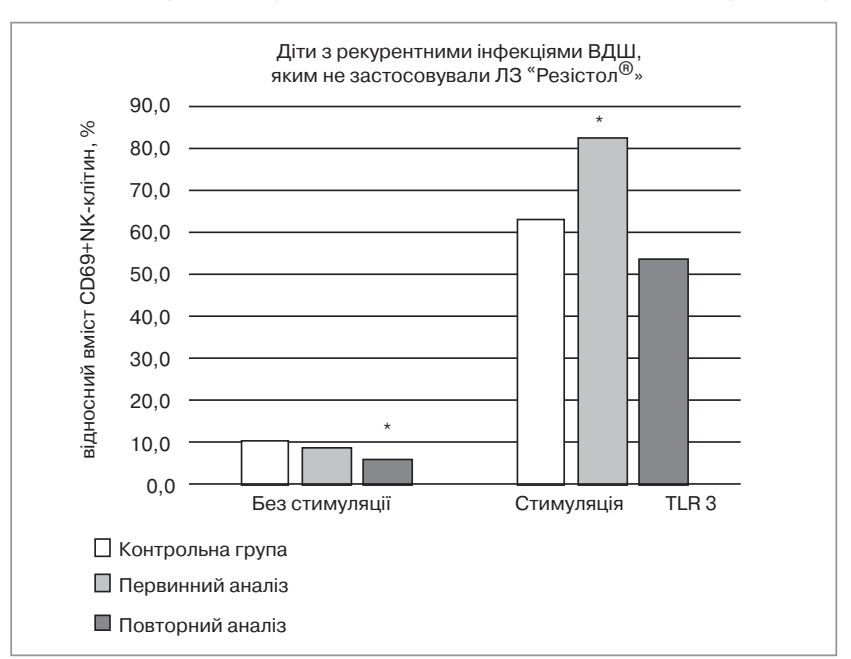

*p $<0,05$ - порівняно з аналогічним показником у контрольній групі

Рис. 11. Зміни відсоткового вмісту активованих CD69+ NK-клітин рекурентними інфекціями ВДШ у групі дітей, яким не застосовували Л3 «Резістол ${ }^{\oplus » ~(г р у п а ~ 2 а), ~ у ~ п о р і в н я н н і ~} 3$ контрольною групою (група 3)

(група 2б), у даній групі (група 2а) спостерігалось достовірне зниження $(\mathrm{p}<0,05)$ відсоткового вмісту NK-клітин з активаційним фенотипом та зниження відсотка NK-клітин, здатних активуватись при стимуляції TLR3 (рис. 11).

Аналіз імунологічних показників у динаміці також виявив відмінності між групами. У групі дітей, у якій не проводили профілактичне використання ЛЗ «Резістол ${ }^{\circledR}$, достовірно знижувався як відносний вміст NK-клітин, так і відсоток цих клітин, здатних активуватись при стимуляції противірусним рецептором TLR3 (рис. 12, 13).

Аналіз імунологічних показників у динаміці також виявив відмінності між групами. У групі дітей, у якій не проводили профілактичне використання ЛЗ «Резістол ${ }^{\circledR}$, достовірно знижувався як відносний вміст NK-клітин, так і відсоток цих клітин, здатних активуватись при стимуляції противірусним рецептором TLR3 (рис. 12, 13).

Тобто у дітей з рекурентними інфекціями ВДШ з часом знижувався активаційний потен- 


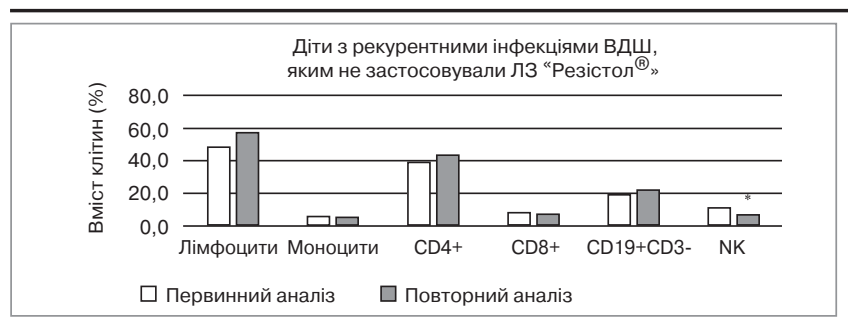

* $<<0,05-$ у порівнянні з первинним аналізом

Pис. 12. Зміни імунологічних показників у групі дітей з рекурентними інфекціями ВДШ, яким не застосовували ЛЗ «Резістол $^{\circledast n}$ (група 2а) з профрілактичною метою (група 3)

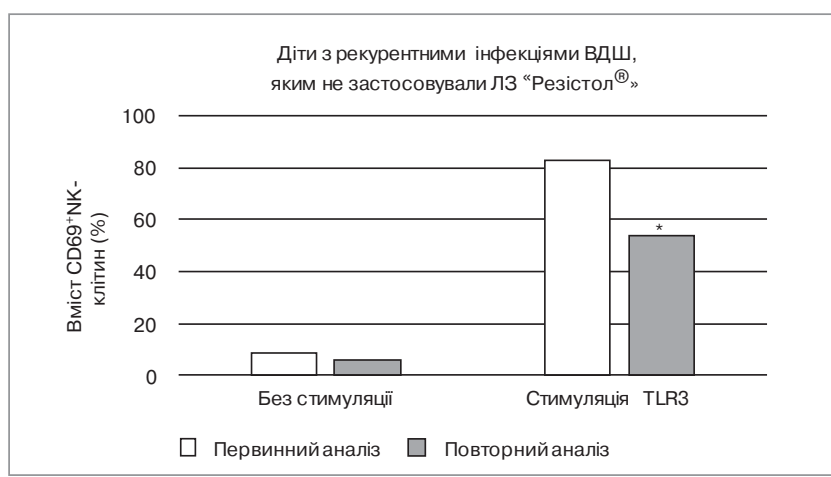

*p $<0,05-$ у порівнянні з первинним аналізом

Pис. 13. Зміна відсоткового вмісту активованих CD69+ NK-клітин у групі дітей з рекурентними інфекціями ВДШ, яким не застосовували Л3 «Резістол ${ }^{\oplus » ~(г р у п а ~ 2 а) ~ з ~ п р о ф р і л а к т и ч н о ю ~ м е т о ю ~}$

ціал противірусної відповіді. Такі зміні можуть бути результатом функціонального виснаження імунних клітин після перенесення інфекцій, але водночас такий знижений активаційний потенціал створює сприятливі умови для повторних інфекцій.

Як і в групах дітей з ГРВІ, у групах дітей 3 рекурентними інфекціями ВДШ порівняльний аналіз концентрації сироваткових цитокінів не виявив достовірних змін (рис. 14, 15).

Таким чином, у дітей з рекурентними інфекціями ВДШ, яким призначався «Резістол®», відсоток NK-клітин, що здатні активуватись при стимуляції TLR-3, залишався сталим, тоді як в групі дітей, які не отримували препарат з профілактичною метою, відбувалося зниження цього показника та відсоткового вмісту активованих NK-клітин.

Обговорення результатів науково-дослідної роботи

Результати науково-дослідної роботи з вивчення стану клітинного імунітету у дітей з ГРВІ та рекурентними інфекціями ВДШ, а також з вивчення впливу ЛЗ «Резістол ${ }^{\circledR} »$, краплі оральні (ПАТ «Галичфарм», Україна) на активність імунного захисту продемонстрували, що суттєві достовірні зміни в показниках клітинного імунітету відбувались саме в групі

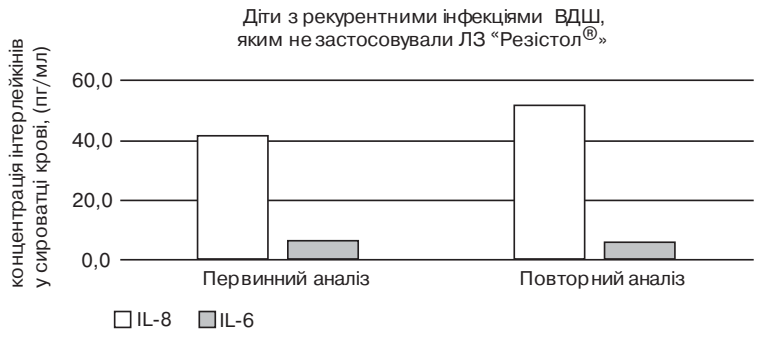

Pис.14. Концентрації сироваткових цитокінів IL-8 та IL-6 у групі дітей з рекурентними інфекціями ВДШ, яким не застосовували ЛЗ «Резістол ${ }^{\circledast »}$ (група 2а)

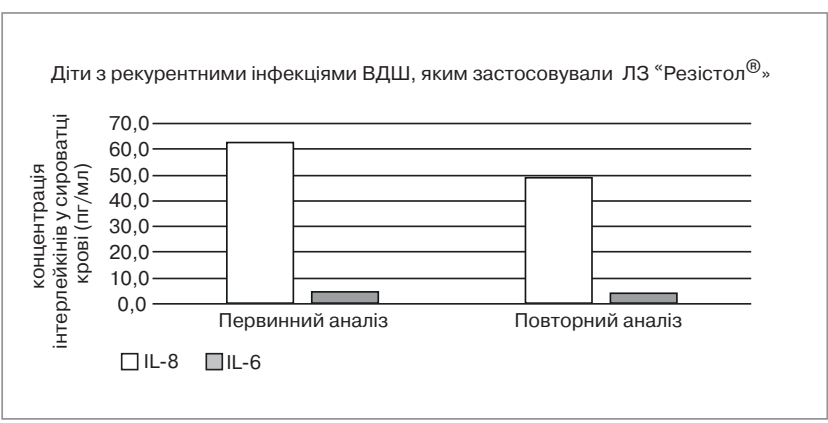

Pис.15. Концентрації сироваткових цитокінів IL-8 та IL-6 у групі дітей $з$ рекурентними інфекціями ВДШ, яким застосовували

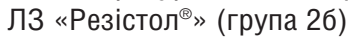

дітей, які на момент проведення роботи були хворі на ГРВІ: у дітей, яким проводилось лікування ГРВІ з використанням ЛЗ «Резістол ${ }^{\circledR} »$, достовірно збільшувалась абсолютна кількість лейкоцитів за рахунок лімфоцитів - клітин, які переважно залучені до елімінації вірусних патогенів; зростала кількість NK-клітин, що здатні активуватись при стимуляції TLR3 та які можуть безпосередньо розпізнавати вірусні патогени. Порівняння результатів дослідження клітинного імунітету в групах дітей з ГРВІ дозволяє зробити висновок, що біологічно активні складові Л3 «Резістол ${ }^{\circledR} »$ мають імуномодулюючі властивості для покращення відповіді клітинного імунітету у дітей з ГРВІ. Враховуючи добру переносимість ЛЗ, відсутність зареєстрованих у дослідженні побічних

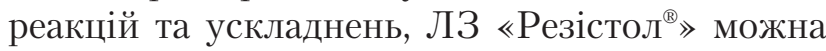
вважати дієвим та безпечним імуномодулюючим ЛЗ в умовах гострого респіраторного захворювання у дітей.

Діти 3 рекурентними інфекціями ВДШ, у яких не використовувався ЛЗ «Резістол ${ }^{\circledR} »$, продемонстрували достовірне зниження як відносного вмісту NK-клітин, так і відсотка цих клітин, що здатні активуватись при стимуляції противірусним рецептором TLR3. А от в групі дітей з рекурентними інфекціями ВДШ, які 
отримували 21-денний курс ЛЗ «Резістол ${ }^{\circledR}$, даний ЛЗ продемонстрував здатність підтримувати активаційний потенціал NK-клітин, можливо, попереджуючи таким чином функціональне виснаження ланки противірусного імунітету. Як було наведено вище, у дітей з рекурентними інфекціями ВДШ зафіксовано зниження активаційного потенціалу противірусної відповіді, що може бути результатом функціонального виснаження імунних клітин після перенесення інфекцій. Але однозначним є те, що такий знижений активаційний потен- ціал противірусної відповіді створює сприятливі умови для розвитку повторних інфекцій.

Тобто найбільш активно свої імуномодулюючі властивості та вплив на підвищення здатності «знищувати» віруси клітинною ланкою імунітету ЛЗ «Резістол ${ }^{\oplus}$ продемонстрував в умовах гострого перебігу інфекційного захворювання. Дітям з рекурентними інфекціями ВДШ 21-денний курс ЛЗ «Резістол ${ }^{\circledast} »$ дає можливість підтримати активаційний потенціал NK-клітин, імовірно, попереджуючи таким чином функціональне виснаження ланки противірусного імунітету.

\section{ЛITEPATУРА}

1. Квашнина ЛВ, Матвиенко ИН, Родионов ВП, Маковская ЮА, Игнатова ТБ. (2015). Применение лекарственного средства Резистол у детей с острыми и хроническими инфекциями дыхательных путей и носоглотки. Педиатрия. Восточная Европа. 3(11):2-15.

2. Чернишова ЛІ, Волоха АП. (2013). Дитяча імунологія. Київ: Медицина.

3. Bellomo R, Bagshaw SM. (2006). Evidence-based medicine: classifying the evidence from clinical trials - the need to consider other dimensions. Crit Care. 10(5): 232.

4. Calvo M, Grob K, Bertoglio J et al. (1990). Secretory IgA deficiency in pediatric patients: clinical and laboratory follow-up. Allergol Immunopathol (Madr.).18;3:149-153.

5. CD69 molecule (Homo sapiens (human)). (2006). https://www.ncbi. nlm.nih.gov/gene/969.

6. Chew V, Tow C, Huang C et al. (2012). Toll-Like Receptor 3 Expressing Tumor Parenchyma and Infiltrating Natural Killer Cells in Hepatocellular Carcinoma Patients. J Natl Cancer Inst. 104:1796-1807.

7. Conrad A, Hansmann C, Engels I et al. (2007, March 5). Extract of Pelargonium sidoides (EPs ${ }^{\oplus} 7630$ ) improves phagocytosis, oxidative burst, and intracellular killing of human peripheral blood phagocytes in vitro. Phytomedicine. 14;1:46-51.

8. Conrad A, Jung I, Tioua D et al. (2007). Extract of Pelargonium Sidoides (EPs 7630) inhibits the interactions of group A-streptococci and host epithelia in vitro. Phytomedecine.14;Vl:52-59.

9. Gonzales C, Williams C, Calderon V. et al. (2012). Antibacterial Role for Natural Killer Cells in Host Defense to Bacillus anthracis. Infect Immun. 80:234-242.

10. Goulopoulou S, McCarthy C, Webb R. (2016). Toll-like Receptors in the Vascular System: Sensing the Dangers Within. Pharmacol Rev. 68:142-67.

11. Guillerey C, Chow M, Miles K et al. (2015). Toll-like receptor 3 regulates NK cell responses to cytokines and controls experimental metastasis. Oncoimmunology. 4:e1027468.

12. Guo Q, Zhang C. (2012). Critical role of Toll-like receptor signaling in NK cell activation. Chin. Sci. Bull. 57:3192.

13. Kayser O, Kolodziej H, Kiderlen AF. (2001). Immunomodulatory principles of Pelargonium Sidoides. Phytother Res. 15:122-126.

14. Koch E, Biber A. 2007 Treatment of rats with Pelargonium Sidoides extract EPs 7630 has no effect on blood coagulation parameters or on the pharmacokinetics of warfarin. Phytomedicine.14;Vl:40-45.

15. Kolodziej H, Kayser O, Radtke OA, Kiderlen AF. (2003) Pharmacological profile of extracts of Pelargonium Sidoides and their constituents. Phytomedecine.10;Vl:18-24.

16. Kolodziej H, Kiderlen AF. (2007). In vitro evaluation of antibacterial and immunoflamatory activities of Pelargonium reniforme, Pelargonium Sidoides and the related herbal drug preparation EPs 7630. Phytomedicine. $14 ; \mathrm{Vl}: 18-26$.

17. Kolodziej H, Schulz V. (2003). EPs 7630: From traditional application to modern phytodrug. Deutsche Apotheker Zeitung. 143:55-64.

18. Lizogub VG, Riley DS, Heger M. (2007). Efficacy of a Pelargonium sidoides preparation in patients with the common cold: A randomized, double-blind, placebo-controlled clinical trial. Explore.3:573-584.

19. Moore T, Kumm P, Brown D, Petro T. (2014). Interferon Response Factor 3 is crucial to poly-l:C induced NK cell activity and control of B16 melanoma growth. Cancer Lett. 346:122-128.

20. Raulet D. (2006). Missing self recognition and self tolerance of natural killer (NK) cells. Semin Immunol. 18:145-150.

21. Wines BD, Hogarth PM. (2006). IgA receptors in health and disease. Tissue Antigens. 68;2:103-114.

22. Woof JM, Kerr MA. (2006). The function of immunoglobulin A in immunity. J. Pathol. 208;2:270-282.

23. Wulff S, Pries R, Wollenberg B. (2010). Cytokine release of human NK cells solely triggered with Poly I:C Cell Immunol.263(2):135-7.

\section{Сведения об авторах:}

Квашнина Людмила Викторовна - д.мед.н., проф., руководитель отделения медицинских проблем здорового ребенка и преморбидных состояний ГУ «ИПАГ имени акад. Е.Н. Лукьяновой НАМН Украины». Адрес: г. Киев, ул. П. Майбороды, 8.

Чернышев Виктор Павлович - д.мед.н., проф., руководитель лаборатории иммунологии с научной группой вирусологии ГУ «ИПАГ имени акад. Е.Н. Лукьяновой НАМН Украины». Адрес: г. Киев, ул. П. Майбороды, 8.

Матвиенко Ирина Николаевна - к.мед.Н., С.Н.С. детского консультативно-диагностического центра ГУ «ИПАГ имени акад. Е.Н. Лукьяновой НАМН Украины»-

Адрес: г. Киев, ул. П. Майбороды, 8.

Игнатова Татьяна Борисовна - к.мед.н., с.н.с. детского консультативно-диагностического центра ГУ «ИПАГ имени акад. Е.Н. Лукьяновой НАМН Украины».

Игнатова Татьяна Борисовна - К.

Осрипчук Дарья Витальевна - к.б.н., гУ «ИПАГ имени акад. Е.Н. Лукьяновой НАМН Украины».

Адрес: г. Киев, ул. П. Майбороды, 8.

Статья поступила в редакцию 12.08.2018, принята к печати 10.12.2018. 


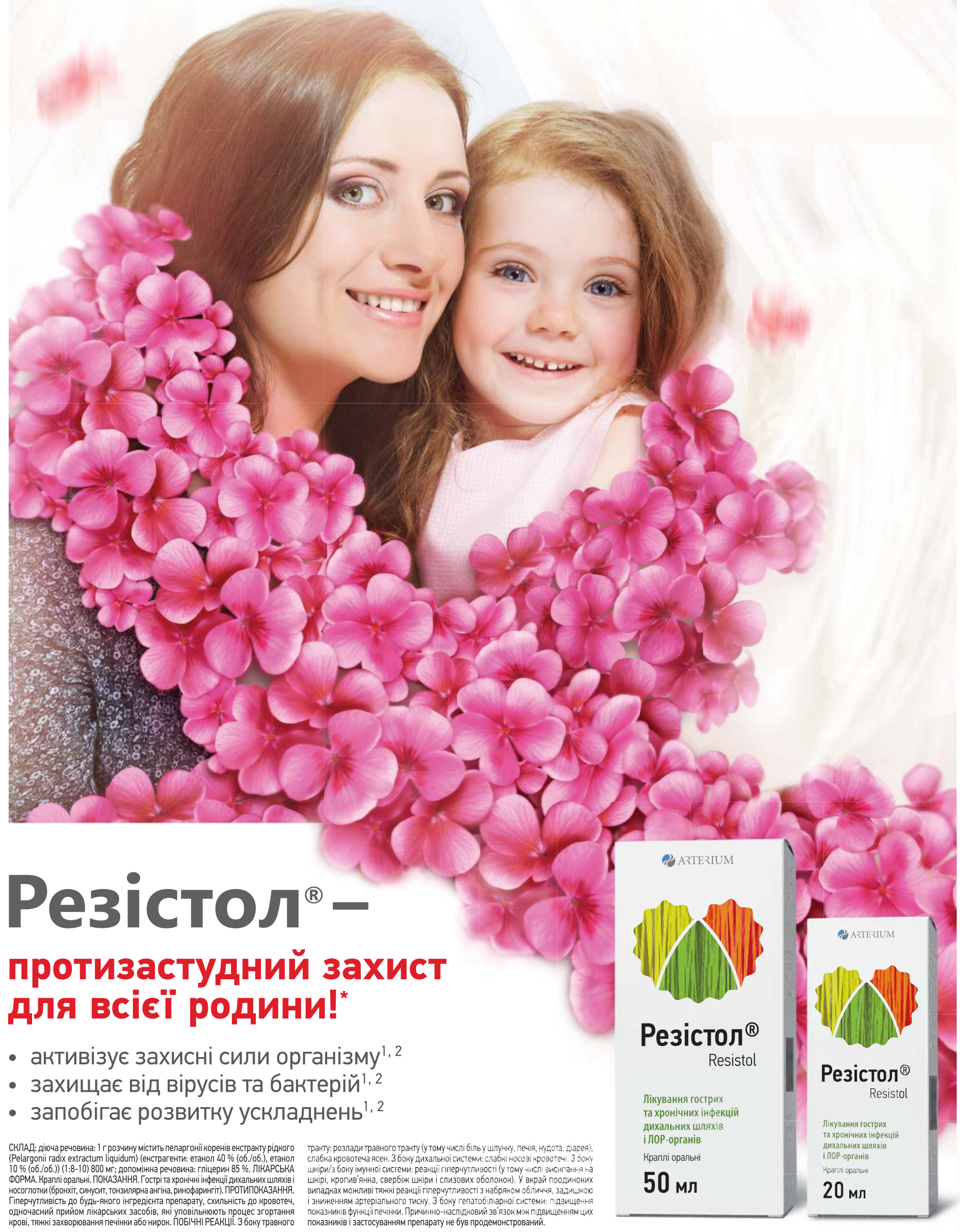

одночасний прийом лікарських засобів, які уповільнюють процес згортання показників фуннціі печінки. Причинно-наслідновий зв язок міжпідвищенням цих

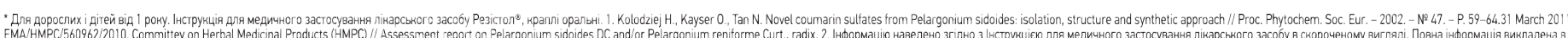

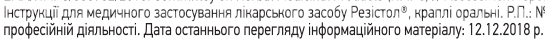

До складу Корпорації «Артеріум» входять ПАТ «Київмедпрепарат» та ПАТ «Галичфарм»

Ближче до людей

«Артеріум» Фармацевтична Корпорація

www.arterium.ua

P ARTERIUM 
УдК 616.321-002-02-036-08-07

\title{
Федір Юрочко \\ Фарингіт і деякі інші. Сучасні тенденції*
}

\author{
Львівська ОДКЛ «ОХМАТДИТ»
}

$\Phi$ арингіт - це запалення глотки, що діагностується клінічно і може бути викликане інфекційними або неінфекційними причинами (Bochner et al., 2017; Gereige, CunillDeSautu, 2011). В англомовній літературі вживаються різноманітні терміни на означення запалення глотки - i pharyngitis, i sore throat, i pharyngotonsillitis. Іноді сюди зараховують і гострий тонзиліт.

\section{Епідеміологія фарингіту}

Фарингіт належить до дуже поширених хвороб. Фарингіт, викликаний стрептококами групи А (СГА), рідко трапляється в дітей віком до 3 років, найчастіше - серед дітей віком 5-15 років (DynaMed Plus, 2018). Гострий фарингіт може бути компонентом інфекційного мононуклеозу, пік захворюваності на який припадає на вік 5-25 років. Зокрема, приблизно 1 з 13 хворих на фарингіт у віці 16-20 років має мононуклеоз (Ebell et al., 2016).

\section{Диференціальна діагностика}

\section{Інфекційні причини}

Найчастіші інфекційні збудники фарингіту наведено в таблиці 1 (всі вікові категорії) та в таблиці 2 (діти).

Якщо в дитини результати дослідження на стрептококи групи А негативні, то поширеними причинами гострого фарингіту в дітей можуть бути M. pneumoniae та C. pneumoniae ці гострі атипові бактеріальні інфекції (серологія або полімеразно-ланцюгова реакція (ПЛР) для M. pпеитопіае або C. pпеитопіае) виявлено в 41\% дітей (Esposito et al., 2006).

Стрептококи не групи А (не-СГА) можуть бути частою причиною фарингіту, так само як i стрептококи групи А, а також вони можуть мати подібні клінічні ознаки (Tiemstra, Miranda, 2009). На основі шкали Центора (таблиця 6) (Centor et al., 1981) не було можливості відрізнити фарингіти, спричинені Streptococcus групи A, від фарингітів, викликаних Streptococcus
Таблиия 1

Частота причин гострого фарингіту в усіх вікових групах (Bisno, 2001)

\begin{tabular}{|c|c|}
\hline Збудник & Частота (\%) \\
\hline Риновіруси (застуда) & 20 \\
\hline $\begin{array}{l}\text { Бета-гемолітичний стрептокок групи А } \\
\text { (стрептококовий фрарингіт, скарлатина) }\end{array}$ & $15-30$ \\
\hline Коронавіруси (застуда) & $\geq 5$ \\
\hline Аденовіруси & 5 \\
\hline Бета-гемолітичний стрептокок групи С & 5 \\
\hline Вірус простого герпесу & 4 \\
\hline Вiрус парагрипу (типи 1-4) & 2 \\
\hline Вірус грипу (типи A та B) & 2 \\
\hline $\begin{array}{l}\text { Інші вірусні патогени (вірус Епштейна- } \\
\text { Барр (Епштейна-Барр асоційований } \\
\text { інсрекційний мононуклеоз), } \\
\text { коксакі вірус (синдром «рука-нога-рот», } \\
\text { герпангіна), цитомегаловірус та ВІЛ-1) }\end{array}$ & $<1$ \\
\hline $\begin{array}{l}\text { Бактеріальні патогени (Neisseria gonorrhoeae } \\
\text { (гонококовий фарингіт), стрептококи групи } \\
\text { G,Corynebacterium diphtheriae, } \\
\text { Arcanobacterium haemolyticum,Chlamydia } \\
\text { pneumoniae та Mycoplasma pneumoniae) }\end{array}$ & $<1$ \\
\hline
\end{tabular}

Таблиия 2

Збудники гострого фарингіту в дітей віком від 6 місяців до 14 років (Esposito et al., 2004)

\begin{tabular}{|l|c|}
\hline \multicolumn{1}{|c|}{ Збудник } & Частота (\%) \\
\hline Аденовірус & 26,8 \\
\hline Респіраторно-синцитіальний вірус & 21,3 \\
\hline Mусорlasma pneumoniae & 19,7 \\
\hline Streptococcus pyogenes & 18,9 \\
\hline Chlamydia pneumoniae & 13,4 \\
\hline Вірус парагрипу 3 типу & 4,7 \\
\hline Вірус грипу В & 3,9 \\
\hline Вірус Епштейна-Барр & 1,6 \\
\hline Вірус грипу А & 0,8 \\
\hline Не виявлено патогенів & 18,9 \\
\hline \multicolumn{2}{|c|}{ Моноінфекція чи комбінована інфекція? } \\
\hline Вид інфекції & Частка (\%) \\
\hline Виявлено тільки вірус & 29,1 \\
\hline Виявлено тільки бактерії & 22,0 \\
\hline Виявлено 2 вірусні збудники & 4,7 \\
\hline Виявлено 2 бактеріальні збудники & 4,7 \\
\hline Виявлено комбінацію вірусних \\
і бактеріальних збудників & 20,5 \\
\hline
\end{tabular}


Рідкісні та менш поширені інфекційні причини гострого фарингіту (Das et al., 2015)

\begin{tabular}{|l|l|l|l|}
\hline \multicolumn{2}{|c|}{ Менш поширені інфекційні причини } & \multicolumn{2}{c|}{ Рідкісні причини } \\
\hline Treponema pallidum & Вторинний сифіліс & Francisella tularensis & Дияртерія \\
\hline $\begin{array}{l}\text { Arcanobacterium } \\
\text { haemolyticum }\end{array}$ & & $\begin{array}{l}\text { Corynebacterium } \\
\text { diphtheriae }\end{array}$ & \\
\hline Yersinia enterocolitica & Єрсиніозний ентероколіт & Chlamydophila psittaci & Чума \\
\hline Chlamydia trachomatis & & Yersinia pestis & \\
\hline & & Лихоманка, спричинена укусом щурів & $\begin{array}{l}\text { Некротичний } \\
\text { гінгівостоматит }\end{array}$ \\
\hline & & $\begin{array}{l}\text { Інфекції, спричинені } \\
\text { змішаними анаеробами }\end{array}$ & Туберкульоз мигдаликів \\
\hline
\end{tabular}

групи C (Fretzayas et al., 2009). Поширеність бета-гемолітичного Streptococcus групи С становила $6,1 \%$ в метааналізі 8 досліджень, що включали обстеження 2729 пацієнтів з болем у горлі в умовах первинної медичної допомоги (Marchello, Ebell, 2016).

Серед студентів віком 15-30 років фарингіт, спричинений Fusobacterium necrophorum, трапляється частіше, ніж фарингіт, спричинений бета-гемолітичним Streptococcus групи A, частота 20,5\% порівняно з 10,3\% (Centor et al., 2015). Також у цьому дослідженні виявляли Mycoplasma pneumoniae в 1,9\% обстежуваних. В іншому дослідженні (Marchello, Ebell, 2016) засвідчено поширеність $F$. necrophorum на рівні 19,4\% у метааналізі 8 досліджень, які включали 2729 пацієнтів з болем у горлі, що обстежувались в умовах первинної медичної допомоги.

Менш поширені інфекційні причини гострого фарингіту наведено в таблиці 3.

Також у дифдіагностиці враховують гострі хвороби глотки, голови та шиї, які можуть проявлятися болем у горлі (Bochner et al., 2017) (таблиця 4).

\section{Неінфекційні причини фарингіту}

Неінфекційні причини фарингіту наведено в таблиці 5 .

\section{Загальна діагностична тактика}

Серед інших причин фарингітів особливо виділяють Streptococcus групи А (СГА) (DynaMed Plus, 2018). При обстеженні важливо розрізнити СГА від вірусної інфекції, а також

Хвороби з болем у горлі (інші, ніж фарингіт)

Таблиия 4

(Bochner et al., 2017)

\begin{tabular}{|l|} 
Гострий епіглотит \\
Ларингіт \\
Паратонзилярний абсцес \\
Ретрофарингеальний абсцес \\
Іррадіація болю внаслідок середнього отиту, \\
абсцесу зуба чи шийного аденіту \\
\hline
\end{tabular}

розпізнати ознаки, що можуть вказувати на серйозніші загрозливі хвороби верхніх дихальних шляхів (Bochner et al., 2017). Нерухомість шиї або обмеження нахилів голови, стридор, надмірна слинотечія, обмеження рухомості шиї, токсичний стан, респіраторний дистрес можуть вказувати на серйозніші хвороби, включаючи заглотковий абсцес, епіглотит, синдром Лем'єра (DynaMed Plus, 2018).

На користь вірусної етіології вказує супутня ринорея, кашель, охриплість, діарея та/або орофарингеальні пухирці. Рекомендують дообстеження на СГА при виявленні петехій на піднебінні, скарлатиноподібних висипань, нудоти та/або ексудатів у горлі з чутливими шийними вузлами.

У пацієнтів з негативним швидким тестом на виявлення антигенів СГА, але з симптомами, подібними до інфекції СГА, включаючи скарлатиноподібні висипання, слід обміркувати наявність інфекції Arcanobacterium haemolyticum (Karpathios et al., 1992).

Діагноз стрептококового фарингіту має бути підтверджений бактеріологічно за допомогою

Неінфекційні причини фарингіту (Bochner et al., 2017; Gereige, Cunill-DeSautu, 2011)

\begin{tabular}{|c|c|}
\hline Причина & Приклад \\
\hline $\begin{array}{l}\text { Післяінтубаційний } \\
\text { фарингіт }\end{array}$ & $\begin{array}{l}\text { Біль горла після операцій, } \\
\text { які супроводжувалися } \\
\text { інтубацією трахеї }\end{array}$ \\
\hline $\begin{array}{l}\text { Гастроезофрагеальна } \\
\text { рефрлюксна } \\
\text { хвороба (ГЕРХ) }\end{array}$ & $\begin{array}{l}\text { Екстраезофрагеальний } \\
\text { рефрлюкс }\end{array}$ \\
\hline $\begin{array}{l}\text { Аутоімунні } \\
\text { причини }\end{array}$ & $\begin{array}{l}\text { Хвороба Стілла у дорослих } \\
\text { Синдром PFAРА (також } \\
\text { відомий як синдром } \\
\text { Маршала) }\end{array}$ \\
\hline $\begin{array}{l}\text { Синдром } \\
\text { постназального } \\
\text { стікання }\end{array}$ & $\begin{array}{l}\text { Інфекція/запалення } \\
\text { (гострий риносинусит) } \\
\text { Алергени (алергічний риніт) }\end{array}$ \\
\hline $\begin{array}{l}\text { Вдихання або проков- } \\
\text { тування токсичних } \\
\text { подразників навко- } \\
\text { лишнього середовища }\end{array}$ & $\begin{array}{l}\text { Алергени, сторонні предмети, } \\
\text { шкідливі випари, куріння }\end{array}$ \\
\hline
\end{tabular}


Шкала Центора (Centor scale) для дифдіагностики стрептококового фарингіту

Таблиия 6

\begin{tabular}{|c|c|}
\hline Шкала Центора & $\begin{array}{c}\text { Мнемонічне правило } \\
\text { для запам'ятовування шкали Центора }\end{array}$ \\
\hline $\begin{array}{l}1 \text { бал за кожен з 4-х критеріїв (гарячка, наліт } \\
\text { на мигдаликах, шийна лімфраденопатія, відсутність кашлю) }\end{array}$ & \multirow{4}{*}{$\begin{array}{l}\mathbf{C} \text { - cough absent (відсутність кашлю) } \\
\mathbf{E} \text { - exudate (наліт на мигдаликах) } \\
\mathbf{N} \text { - nodes (лімфовузли шийні) } \\
\text { T - temperature (fever)(температура, гарячка) } \\
\text { OR - young OR old modifier(молодий або старший) }\end{array}$} \\
\hline +1 бал, якщо вік <15 років & \\
\hline -1 бал якщо >45 років & \\
\hline $\begin{array}{l}\text { 0-1 бал - дуже низький ризик стрептококового фарингіту } \\
\text { 3-4 бали - підвищений ризик стрептококового фрарингіту }\end{array}$ & \\
\hline
\end{tabular}

швидкого тесту на виявлення антигенів або посіву мазка з горла в пацієнтів з фарингітом (DynaMed Plus, 2018).

Варто розглянути можливість використання модифікованих балів шкали Центора (таблиця 6), щоб допомогти ідентифікувати пацієнтів із стрептококовим фарингітом.

Стрептококовий фарингіт малоймовірний у більшості дітей віком до 3 років, але при виконанні швидкого антигенового тесту на стрептококи потрібно враховувати, чи не є позитивним цей тест у співмешканців дитини і чи відвідує дитина дошкільний заклад. У дітей та підлітків 3 негативним швидким тестом на виявлення антигену слід виконати посів мазка 3 горла, щоб остаточно підтвердити відсутність стрептококу (DynaMed Plus, 2018).

\section{Клінічні ознаки окремих фарингітів}

\section{Стрептококовий фарингіт}

Cтрептококовий фарингіт (Streptococcus әрупи A) найчастіше трапляється у дітей шкільного віку та підлітків, взимку та ранньої весни (Bochner et al., 2017). Типові прояви: раптовий початок болю в горлі, що часто поєднується 3 гарячкою, болем при ковтанні та підвищеною чутливістю шийних лімфатичних вузлів. Маловірогідними є виділення 3 носа, кашель, кон'юнктивіт, охриплість, діарея.

Скарлатина (фарингіт, спричинений бетагемолітичним стрептококом групи А, у поєднанні зі шкірним висипанням) (Paul, Heaton, 2014). Гостра бактеріальна інфекція з характерною дифузною еритематозною висипкою i фарингітом. Як звичайно, викликаний екзотоксином Streptococcus групи А, але також може бути спричинений ентеротоксином певних штамів стафілококів. Найчастіше трапляється у дітей. Діагноз встановлюють на підставі типових клінічних ознак: гарячка, біль у горлі, болі голови, озноб, нудота, блювання.

Для скарлатини характерний висип, що з'являється протягом 24-48 годин після появи симптомів, - дрібноточкове червоне висипан- ня, яке починається на тулубі та обличчі на 2-3 день розпалу захворювання, текстура висипання класично описана на відчуття як «наждачний папір», еритема швидко поширюється до кінцівок, зазвичай оминає долоні та підошви; як звичайно, висипання зникає на 4-5 день i починається злущування, яке може тривати до кількох тижнів (DynaMed Plus, 2018).

Типовим для скарлатини є «полуничний» язик - спочатку з'являється «білий полуничний» язик (білий язик з червоними опухлими сосочками), а на 4-5 день - язик у вигляді червоної полуниці (або яловичини).

Лікування антибіотиками може зменшити тривалість симптомів і ризик розвитку ревматизму.

Фарингіти, спричинені не стрептокока$\boldsymbol{s} \boldsymbol{u}$ групи $\boldsymbol{A}$. Клінічна картина може бути такою ж, як і при СГА, але перебіг легшим. Можуть частіше траплятися у дорослих пацієнтів. Гострі фарингіти, спричинені стрептококами групи $\mathrm{C}$ та G, можуть бути пов'язані з вживанням забрудненої їжі, наприклад молока (Bisno, 1996). Стрептококи групи $\mathrm{C}$ та $\mathrm{G}$ зазвичай містяться в ротоглотці як коменсальні організми, про їх патогенність свідчитиме підвищений рівень антистрептолізину-О (Fretzayas et al., 2009). Невідомо, чи лікування інших стрептококів (не-СГА) антибіотиками сприяє швидшому зникненню симптомів (Shulman et al., 2012). Є повідомлення, що інфекції, спричинені стрептококами групи $\mathrm{C}$ та $\mathrm{G}$, в окремих випадках сприяють розвитку гломерулонефритів, проте немає доказів, що лікування антибіотиками може цьому запобігти (Beres et al., 2008).

Інші поширені інфекційні захворювання

Епштейна-Барр-асоційований мононуклеоз. Типовими симптомами є втома, нездужання, підвищення температури тіла, біль у горлі, наліт на мигдаликах і лімфаденопатія задніх шийних вузлів. Збільшення селезінки наявне в 50\% дітей та підлітків (Cohen, 2003).

Інфекція, спричинена Коксакі вірусом $\boldsymbol{B}$, може проявлятись як герпангіна і характеризу- 
ється продромальним періодом з раптовою гарячкою, болем голови, загальним нездужанням, болями у спині/шиї з подальшою появою болючих виразок на слизовій рота, еритематозного фарингіту, дисфагії. Локально при герпангіні виявляють приблизно 20 малих (1-4 мм) сіро-білих пухирців на гіперемованій слизовій задньої стінки глотки, язичка та дужок мигдаликів (DynaMed Plus, 2018).

Гонококовий фарингіт можна запідозрити в пацієнтів 3 оральним сексом в анамнезі й такими симптомами, як орофарингеальна еритема, орофарингеальний наліт або шийна лімфаденопатія. Частота гонококового фарингіту найбільша в підлітків і молодих людей; 40\% обстежених пацієнтів були жінками віком 15-19 років (DynaMed Plus, 2018).

Аденовірусний фарингіт типово проявляється гарячкою, болем у горлі та носовими симптомами; 50\% пацієнтів мають кон'юнктивіт.

Фарингіт, викликаний Arcanobacterium haemolyticum, може проявлятися такими ж симптомами, як й інфекція, спричинена СГА, включно з скарлатиноподібними висипаннями (Karpathios et al., 1992).

Загрозливі стани, при яких наявний фарингіт

Паратонзилярний абсцес. Пік захворюваності на паратонзилярний абсцес (Bochner et al., 2017) припадає на вік 13,6 року, а загальна захворюваність становить 9,4 на 100000 населення (США, у 2009 р.). Найпоширеніші симптоми: гарячка, нездужання, сильний біль у горлі, болі при ковтанні, дисфагія, приглушений голос. Об'єктивні ознаки - напружений набряк та гіперемія передньої дужки мигдалика та м'якого піднебіння, часто з передньо-медіальним зміщенням ураженого мигдалика та язичка в протилежну сторону; тризм (спазм жувальних м'язів), при якому відкриття рота утруднене через біль внаслідок запалення та спазм жувальних м'язів; надмірне виділення слини; відчуття гіркоти в роті, неприємний запах 3 рота; підвищена чутливість шийних лімфатичних вузлів на ураженому боці або з обох сторін.

Гострий епіглотит. Найчастішим проявом гострого епіглотиту є раптовий початок таких симптомів, як висока гарячка, сильні болі в горлі, охриплість, болючість при ковтанні та надмірне слиновиділення. В пацієнтів цей діагноз можна запідозрити при наявності таких гострих клінічних ознак, як гарячка, стридор, фарингіт, болючість при ковтанні, надмірне слиновиділення, задишка (в підлітків); положення триноги в поєднанні 3 тривогою, надмірне слиновиділення, задишка, дисфонія, дисфагія та стридор (в дітей). При наявності дихальної недостатності діагностичні процедури повинні бути відкладені, пріоритетом є забезпечення прохідності дихальних шляхів (DynaMed Plus, 2018).

Заглотковий абсцес. Частота заглоткових абсцесів (Bochner et al., 2017) найвища в дітей віком до 5 років. Ця хвороба частіша у хлопчиків, а i частота в США від 2003-го до 2011 р. зросла від 2,98 до 4,1 на 100000 (Gereige, Cunill-DeSautu, 2011). Симптоми розвиваються внаслідок набряку i накопичення гною в ретрофарингеальному просторі. Вони різноманітні й неспецифічні, починаючи від легких (дратівливість, біль голови та втрата апетиту) до класичної тріади - кривошия, підвищення температури тіла (може бути $>38,3^{\circ} \mathrm{C}$ ), а також болючість при ковтанні. Інші симптоми - токсичний вигляд, хрипи, надмірне слиновиділення, дисфагія та тризм. Потрібно оцінити наявність ознак потенційно загрозливих симптомів дихальних шляхів (таблиця 7).

Хвороба Лем'єра - це гнійний тромбофлебіт яремної вени, що може виникнути внаслідок фарингіту, спричинений Fusobacterium necrophorum (Eilbert, Singla, 2013). Типові найпоширеніші симптоми - гарячка, біль у горлі, озноб, блювання й односторонній біль у шиї. Ознаками погіршення є поява на 4-5 день таких симптомів, як тривала та прогресуюча гарячка, приглушення свідомості, озноб.

\section{Рідкісні інфекційні захворювання}

Гостра ВIЛ інфекиія може проявлятись фарингітом чи болем горла в 40-60\% пацієнтів.

Дифтерія рідко трапляється в країнах 3 плановими вакцинаціями і малою часткою відмов від вакцинації; натомість в Україні зростає ризик епідемії дифтеріі. Типовими є специфіч-

Загрозливі симптоми заглоткового абсцесу

Таблиия 7

\begin{tabular}{l}
\hline Задишка \\
Стридор \\
Тахіпное з поверхневим диханням \\
\hline Використання додаткових м'язів \\
Положення ортопное \\
Пацієнт перебуває в положенні \\
з максимально закинутою головою, \\
прагнучи максимально збільшити \\
прохідність дихальних шляхів
\end{tabular}


ні сіро-білі «брудні» плівки на піднебінні, мигдаликах і на задній стінці глотки. При спробі усунути плівки вони погано знімаються з підлеглих тканин. $€$ невеликий біль у горлі, втрата апетиту, нездужання та зниження температури, ознаки інтоксикації. Може бути набряк шиї, охриплість голосу. Початок поступовий, симптоми виникають на 2-5 день після появи плівок (DynaMed Plus, 2018).

Фарингіт при єрсиніозному ентероколіті. Прояви - гастроентерит з блюванням, іноді кров'яниста діарея; фарингіт є досить рідкісним проявом (Garcia-Callejo et al., 2011).

Вторинний сифіліс проявляється різноманітними орофарингеальними виразками у $7-56 \%$.

Цитомегаловірусна (ЦМВ) інфекція. ЦМВ інфекція переважно $є$ асимптомною в імунокомпетентних осіб, включаючи немовлят. Симптоми, як звичайно, включають легкий грипоподібний стан або мононуклеозоподібний синдром. Порівняно з мононуклеозом, викликаним вірусом Епштейна-Барр, симптоми, пов'язані з ЦМВ інфекцією, найчастіше включають міальгії, артральгії та кашель, а також, рідше, - болі в горлі та лімфаденопатію (DynaMed Plus, 2018).

Деякі рідкісні або дуже рідкісні стани, що проявляються фарингітом, можуть бути спричинені контактами з деякими тваринами:

1. Туляремія. Симптоми включають гарячку, озноб, біль голови, кашель, міалгії, ураження шкіри; фарингіт, кон'юнктивіт і регіонарну лімфаденопатію. Анамнез може включати укуси кліщів або оленів, а також укуси інших тварин, зокрема дрібних ссавців, таких як кролики, або ж контакт з їх тушами.

2. Лихоманка Хаверхіл (Haverhill fever) це рідкісна форма інфекції Streptobacillus moniliformis, або лихоманки від укусу щурів.

\section{Неінфекційні стани}

Післяопераційні болі в горлі. Після операцій із загальною анестезією і застосуванням інтубації трахеї засвідчено частоту фарингіту від 21 до 71\% випадків. Симптоми можуть утримуватися протягом кількох днів. До факторів ризику належать використання ендотрахеальної трубки $>6$ мм, подвійних трубок, високий тиск манжетки на трубі, жіноча стать, молодий вік, пролонгована анестезія та наявність кров'яного вмісту в ендотрахеальній трубці після екстубаціï (El-Boghdadly et al., 2016).
Гастроезофеагальна рефлюксна хвороба (ГEPX) може проявлятись позастравохідними симптомами, такими як охриплість, дисфонія, болі або першіння в горлі, відхаркування, хронічний кашель, дисфагія, гранульоми гортані, ларингоспазм (Madanick, 2014).

Алергічний риніт внаслідок постназального стікання може проявлятися чханням, ринореєю та закладеністю носа, особливо навесні та восени (Gereige, Cunill-DeSautu, 2011), а також змінами в глотці - почервонінням, дискомфортом, покашлюванням. Часто при огляді виявляють гранули на задній стінці глотки, іноді їх так багато, що вони нагадують бруківку («синдром бруківки»).

Токсичний вплив навколишніх чинників, що вдихаються або проковтуються, часто пов'язаний з хобі чи професійним анамнезом людини (Bochner et al., 2017; Gereige, Cunill-DeSautu, 2011) - алергени, сторонні предмети (наприклад, рибна кістка), шкідливі випари, куріння.

Синдром PFAPA (також відомий як синдром Маршала) - періодичні лихоманки, афтозний стоматит, фарингіти та шийний лімфаденіт. Переважно виникає у віці до 5-ти років. Вважають, що це аутоімунна хвороба, а не запалення. Типовою є часова періодичність між нападами гарячки, при цьому батьки, як звичайно, здатні передбачити наступну появу; характерний інтервал становить від 21 до 28 днів. Під час гарячки, що триває 3-5 днів, можна помітити афти (дрібні виразки на слизовій оболонці глотки та щік), фарингіт (гіперемовані збільшені мигдалики), шийний лімфаденіт (Soon, Laxer, 2017). Важливим діагностичним критерієм синдрому PFAPA $€$ позитивна реакція на одноразове введення системних кортикостероїдів (швидке і стійке зниження гарячки).

Хвороба Стілла в дорослих. Це системна аутоімунна хвороба дорослих (Akkara Veetil et al., 2012). Типові прояви неспецифічні й включають гарячку, яка завжди передує появі інших симптомів. Поширеними симптомами є поліартрит або артралгії, шкірний висип та біль у горлі.

\section{Додаткові методи обстеження}

Для пацієнтів з симптомами фарингіту, спричиненого стрептококом групи А, виконують швидкі тести на виявлення антигенів та/або посів мазка з горла (Harris et al., 2016). 
Швидкий тест виявлення антигенів має високу специфічність, тому при позитивному результаті слід призначити антибіотик. Позитивний тест не потребує додаткового посіву для підтвердження. Проте в дітей та підлітків негативний тест слід підтверджувати посівом мазка з горла. А в підлітків не рекомендують посівів при негативному швидкому тесті (Shulman et al., 2012). Швидкі антигенові тести можуть зменшити частоту призначення антибіотиків.

Тести, які потрібно робити при інших діагнозах: швидкий антигенний тест на виявлення грипу, гетерофільне тестування антитіл (Monosot) для виявлення мононуклеозу.

При виконанні загального аналізу крові можна виявити таке: лімфоцитоз та підвищена кількість атипових мононуклеарів свідчать на користь мононуклеозу; лейкоцити і лейкоцитарна формула вказують на тяжкість паратонзилярного абсцесу або ретрофарингеального абсцесу; пацієнти з синдром РFAРА можуть мати незначний лейкоцитоз із нейтрофілією і помірний зсув формули вліво (DynaMed Plus, 2018).

Підвищення гострофазових показників, таких як С-реактивний білок та швидкість осідання еритроцитів, можна спостерігати при хворобі Стілла в дорослих або синдромі PFAРА.

Коли є підозра на серйозніші хвороби, виконання радіологічних обстежень буде корисним, якщо витрата часу на них не вплине на стан хворого. Бокова рентгенографія шиї показана при гострому епіглотиті або заглотковому абсцесі. Комп'ютерна томографія з контрастуванням або магнітно-резонансна томографія є ще одним варіантом для оцінки можливого заглоткового абсцесу.

\section{Лікування}

\section{Місцеве лікування}

Рекомендують місцеві препарати для розсмоктування (наприклад, пастилки для горла). Незважаючи на дискусії щодо доцільності місцевого застосування ліків при фарингіті, є багато доказів ефективності такого лікування. Місцеві препарати у вигляді таблеток для розсмоктування найдовше забезпечують дію порівняно зі спреями для горла.

Перспективним напрямом, який підтвердив свою клінічну ефективність, є застосування лізоциму при місцевому лікуванні фарингіту.

Лізоцим належить до ензибіотиків - групи природних ферментів з антимікробною активністю (Catic et al., 2016), відкритий Алексан- дром Флемінгом ще в 1922 р. (Fleming, 1922). Його антимікробна активність пов'язана з ферментним впливом на пептидоглікани мікробної стінки (ензимні механізми), а також активацією бактеріальних аутолітичних механізмів, агрегацією бактерій і дестабілізацією їх цитоплазми (неензимні механізми) (Wang, Germaine, 1991). Лізоцим також проявляє противірусну, протигрибкову, протизапальну, імуномодуляторну, регенеративну та антиоксидантну дію (Catic et al., 2017).

В клінічних дослідженнях доведено високу ефективність лізоциму при місцевому застосуванні при фарингіті (Pan et al., 2011; Catic et al., 2016).

В Україні лізоцим для місцевого застосування при фарингіті доступний у вигляді препарату Лісобакт ${ }^{\circledR}$. Унікальність цього препарату в тому, що він містить найбільшу концентрацію лізоциму - 20 мг, що вигідно вирізняє Лісобакт від інших лізоцимвмісних препаратів.

Лісобакт ${ }^{\circledR}$ крім лізоциму містить піридоксин (вітамін В6), який забезпечує антиоксидантний захист, зменшує ушкодження клітин, сприяє їх регенерації, контролює запальні реакції на фоні інфекційних процесів, коли потреба в піридоксині істотно зростає (Бекетова, Солдатова, 2017).

\section{Системні кортикостероїди}

Також при фарингіті рекомендують кортикостероїди. Більшість досліджень щодо кортикостероїдів рекомендують одноразову дозу дексаметазону - 10 мг (еквівалент 67 мг преднізону). Кортикостероїди можуть прискорити полегшення болю при гострому фарингіті незалежно від вірусної чи бактеріальної етіологіï, а також коли їх застосовують як монотерапію в пацієнтів з інфекційним мононуклеозом (Hayward et al., 2017; Olympia et al., 2005; Hayward et al., 2012).

При синдромі PFAРА (також відомому як синдром Маршала) при епізодах загострення антибіотики, як звичайно, неефективні. Лікування преднізоном (разова доза 0,6-2 мг/кг) при появі симптомів може зупинити епізод захворювання в більшості пацієнтів. Може бути потрібно повторити дозу на наступний день при наявності симптомів. Лікування преднізоном може призвести до скорочення інтервалу між епізодами. Також рекомендують циметидин (2 розділені дози 40 мг/кг), він запобігає рецидиву в третини пацієнтів. Розглядають тонзилектомію з аденоїдектомією або без неї, 
Антибіотики при фарингіті, спричиненому стрептококом групи A (Shulman et al., 2012) Для пацієнтів без алергії на пеніциліни

\begin{tabular}{|c|c|}
\hline \multicolumn{2}{|r|}{ Для пацієнтів без алергії на пеніциліни } \\
\hline $\begin{array}{l}\text { Пеніцилін V } \\
\text { (феноксиметилпеніцилін) }\end{array}$ & $\begin{array}{l}\text { Діти - по } 250 \text { мг перорально 2-3 рази на день } 10 \text { днів. Дорослі та підлітки - } \\
\text { по } 250 \text { мг } 4 \text { рази на день або } 500 \text { мг двічі на день - } 10 \text { днів }\end{array}$ \\
\hline Амоксицилін & $\begin{array}{l}50 \text { мг/кг перорально один раз на день (максимум } 1000 \text { мг) або } 25 \text { мг/кг } \\
\text { (500 мг максимальна доза) двічі на день - } 10 \text { днів }\end{array}$ \\
\hline $\begin{array}{l}\text { Бензатин пеніцилін G (терапія } \\
\text { для пацієнтів, які неохоче } \\
\text { сприймають 10-тиденний курс } \\
\text { перорального лікування) }\end{array}$ & $\begin{array}{l}\text { Пацієнти <27 кг - } 600000 \text { одиниць в/м одноразово } \\
\text { Пацієнти } \geq 27 \text { кг }-1200000 \text { одиниць в/м одноразово }\end{array}$ \\
\hline \multicolumn{2}{|r|}{ Для пацієнтів з алергією на пеніциліни } \\
\hline Цефалексин & $\begin{array}{l}20 \text { мг/кг перорально двічі на день (максимальна доза } 500 \text { мг) на } 10 \text { днів, } \\
\text { але уникати його, якщо наявний негайний тип гіперчутливості до пеніциліну }\end{array}$ \\
\hline Цефадроксил & $\begin{array}{l}30 \text { мг/кг перорально один раз на день (максимум } 1 \text { г) на } 10 \text { днів, } \\
\text { але уникати його, якщо наявний негайний тип гіперчутливості до пеніциліну }\end{array}$ \\
\hline Кліндаміцин & $\begin{array}{l}7 \text { мг/кг перорально три рази на день (максимальна доза } 300 \text { мг) } \\
\text { на } 10 \text { днів }\end{array}$ \\
\hline Азитроміцин & $\begin{array}{l}12 \text { мг/кг перорально один раз на день (максимальна доза } 500 \text { мг) } \\
\text { на } 5 \text { днів (перевірте на стійкість до Streptococcus групи A) }\end{array}$ \\
\hline Кларитроміцин & $\begin{array}{l}\text { 7,5 мг/кг перорально двічі на день (максимальна доза } 250 \text { мг) } \\
\text { на } 10 \text { днів (перевірте на стійкість до Streptococcus групи A) }\end{array}$ \\
\hline
\end{tabular}

що може привести до тривалої ремісії і є варіантом для дітей, що потребують частого лікування кортикостероїдами. Прогноз при синдромі PFAPA такий: тяжкість і частота зменшуються в підлітковому віці (середня тривалість симптоматики 6,3 року), але тривалість може сягати і 18,1 року в 15\% пацієнтів (Soon, Laxer, 2017).

\section{Антибіотики}

Фарингіт, спричинений стрептококом групи A, є єдиною формою гострого фарингіту, коли антибіотики однозначно показані (таблиця 8).

Заборони відвідування школи при гострому стрептококовому фарингіті з легким перебігом немає (Richardson et al., 2001).

Не доведено переваги лікування антибіотиками глоткових інфекцій, викликаних Streptococcus групи C (СГС) або Streptococcus групи G (CГG). В клінічних дослідженнях немає жодних доказів, що антибіотики полегшують клінічні симптоми фарингітів, спричинених CГC та CГG. Немає жодних доказів, що гостра ревматична лихоманка може бути ускладненням фарингітів, спричинених СГС та СГG. Гострий гломерулонефрит є дуже незвичним при фарингіті, спричиненому СГG (Shulman et al., 2012).

Лікування пацієнтів з гонококовою інфекцією (інфекцією Neisseria gonorrhoeae), а також інфекцією Chlamydia trachomatis є емпіричним. Центр контролю та запобігання захворюванням (Centers for Disease Control and Prevention $(C D C))$ рекомендує застосовувати в першу чергу для дорослих цефтріаксон 250 мг в/м одноразово, азитроміцин 1 г перорально одноразово (Workowski, Bolan, 2015). Європейський міжнародний союз проти інфекцій (European International Union against Sexually Transmitted Infections, IUSTI), що передаються статевим шляхом, та Всесвітня організація охорони здоров'я (ВООЗ) рекомендують вищу дозу обох антибіотиків з огляду на виникнення бактеріальних штамів зі зниженою чутливістю до цих препаратів - цефтріаксон 500 мг в/м одноразово, азитроміцин 2 г перорально одноразово (Bignell, Unemo, 2013). Також слід радити для пацієнтів 3 гонококовим фарингітом таке: сексуальні партнери потребують повного обстеження та лікування, а також утримання від сексуальної активності до закінчення лікування та зникнення симптомів (Workowski, Bolan, 2015).

Антибіотики можуть трохи зменшити час зникнення симптомів. Порівнюючи позитивний посів мазка з горла на стрептокок і негативний, можна сказати, що антибіотики є ефективнішими в пацієнтів 3 доведеною стрептококовою інфекцією. Загалом антибіотики скорочували тривалість хвороби приблизно на 16 годин (Spinks et al., 2013).

Антибіотики можуть скоротити тривалість гарячки в пацієнтів з фарингітом, але можуть не скоротити тривалість захворювання (Little et al., 1997)

\section{Прогноз}

Загалом фарингіт є хворобою зі сприятливим перебігом.

В окремих випадках, коли причиною $є$ стрептокок групи A, показані антибіотики. 
Симптоми можуть тривати від 2 до 7 днів у більшості дітей із болем у горлі, вони зникають до 3 дня у 67\% дітей (Thompson et al., 2013). Однак іноді виникають ускладнення. Гнійні ускладнення виникають в 1,3\% дорослих з гострим болем горла, 14,2\% хворих зверталося за повторними консультаціями щодо нових або старих симптомів (Little et al., 2013). Також не слід забувати про рідкісні причини фарингіту.

Точна діагностика в поєднанні з адекватною лікувальною тактикою допоможуть пацієнту швидше одужати без зайвого лікування.

\section{ЛITЕРАТУРА}

1. Бекетова Г.В., Солдатова О.В. (2017, жовтень). Можливості місцевої імуномодулюючої та репаративної терапії в дітей з рекурентними захворюваннями респіраторного тракту і порожнини рота. Здоров'я України. Педіатрія. 19(416): 10-11.

2. Akkara Veetil BM, Yee AH, Warrington KJ, Aksamit AJ Jr, Mason TG (2012, Dec). Aseptic meningitis in adult onset Still's disease. Rheumatol Int. 32(12): 4031-4.

3. Beres SB, Sesso R, Pinto SW, Hoe NP, Porcella SF, Deleo FR, Musser JM. (2008, Aug). Genome sequence of a Lancefield group C Streptococcus zooepidemicus strain causing epidemic nephritis: new information about an old disease. PLoS One. 21; 3(8): e3026. doi 10.1371/journal.pone. 0003026 .

4. Bignell C, Unemo M; European STI Guidelines Editorial Board. (2013, Feb). 2012 European guideline on the diagnosis and treatment of gonorrhoea in adults. Int J STD AIDS. 24(2): 85-92. doi $10.1177 / 0956462412472837$.

5. Bisno AL. (2001, Jan). Acute pharyngitis. N Engl J Med. 18; 344 (3): 205-11.

6. Bisno AL. (1996, Jun). Acute pharyngitis: etiology and diagnosis. Pediatrics. 97; 6(Pt 2): 949-54.

7. Bochner RE, Gangar M, Belamarich PF. (2017., Feb). A Clinical Approach to Tonsillitis, Tonsillar Hypertrophy, and Peritonsillar and Retropharyngeal Abscesses. Pediatr Rev. 38(2): 81-92.

8. Catic T, Mehic V, Binakaj Z et al. (2016, Dec). Efficacy and Safety of Oral Spray Containing Lysozyme and Cetylpyridinium: Subjective Determination of Patients with Tonsillopharyngitis Mater Sociomed. 28(6): 459-463.

9. Catic T et al. (2017, Jan). Lysozyme - Enzybiotic as a potential solution of the global problem of antibiotic resistance Farmaceutski glasnik. 73(4): 273-288.

10. Centor RM, Atkinson TP, Ratliff AE, Xiao L, Crabb DM et al. The clinical presentation of Fusobacterium-positive and streptococcalpositive pharyngitis in a university health clinic: a cross-sectional study. Ann Intern Med. 2015 Feb 17;162(4):241-7. doi: 10.7326/ M14-1305.

11. Centor RM; Witherspoon JM; Dalton HP; Brody CE; Link K. (1981). The diagnosis of strep throat in adults in the emergency room. Medical Decision Making. 1(3): 239-246.

12. Cohen Jl. (2003, Apr). Benign and malignant Epstein-Barr virusassociated B-cell lymphoproliferative diseases. Semin Hematol. 40(2): 116-23.

13. Das A, Das SK, Pandit S, Basuthakur S. (2015, Jan-Mar). Tonsillar tuberculosis: a forgotten clinical entity. J Family Med Prim Care.4 (1): 124-6. doi 10.4103/2249-4863.152268.

14. DynaMed Plus. (2018, May 04). Ipswich (MA): EBSCO Information Services. 1995. Record No. 114913, Pharyngitis approach to the patient. Available from http://www.dynamed.com /login.aspx? direct=true\&site= DynaMed\&id $=114913$.

15. Ebell MH, Call M, Shinholser J, Gardner J. (2016, Apr 12). Does This Patient Have Infectious Mononucleosis?: The Rational
Clinical Examination Systematic Review. JAMA. 315(14): 1502-9. doi 10.1001/jama.2016.2111.

16. Eilbert W, Singla N. (2013). Lemierre's syndrome. Int J Emerg Med. 6: 40.

17. El-Boghdadly K, Bailey CR, Wiles MD. (2016, Jun). Postoperative sore throat: a systematic review. Anaesthesia. 71(6): 706-17. doi 10.1111/anae.13438. Epub 2016 Mar 28.

18. Esposito S, Blasi F, Bosis S, Droghetti R, Faelli N, Lastrico A, Principi N. (2004, Jul). Aetiology of acute pharyngitis: the role of atypical bacteria. J Med Microbiol. 53; Pt 7: 645-51.

19. Esposito S, Bosis S, Begliatti E, Droghetti R, Tremolati E, Tagliabue C, Bellasio M, Blasi F, Principi N. (2006, Jul 15). Acute tonsillopharyngitis associated with atypical bacterial infection in children: natural history and impact of macrolide therapy. Clin Infect Dis. 43(2): 206-9. Epub 2006 Jun 12.

20. Fleming A.On a remarkable bacteriolytic element found in tissues and secretions. Proc R Soc Lond B,1922,93:306-317.

21. Fretzayas A, Moustaki M, Kitsiou S, Nychtari G, Nicolaidou P. (2009, Aug). The clinical pattern of group C streptococcal pharyngitis in children. J Infect Chemother. 15(4): 228-32. doi 10.1007/s10156009-0694-8. Epub 2009 Aug 18.

22. Garcia-Callejo FJ, Minguell-Gonzalez P, Benavent-Corai V, SantonjaLopez N, Munoz-Fernandez N, Marco-Algarra J. (2011, Sep-Oct). Yersinia enterocolitica tonsillitis. Article in Spanish Acta Otorrinolaringol Esp. 62(5): 381-4. doi 10.1016/j.otorri.2011.01.012. Epub 2011 Apr 8.

23. Gereige R, Cunill-DeSautu B. (2011, Nov). Throat infections. Pediatr Rev. 32(11): 459-68.

24. Harris AM, Hicks LA, Qaseem A. (2016, Mar 15). High Value Care Task Force of the American College of Physicians and for the Centers for Disease Control and Prevention. Appropriate Antibiotic Use for Acute Respiratory Tract Infection in Adults: Advice for High-Value Care From the American College of Physicians and the Centers for Disease Control and Prevention. Ann Intern Med.164(6): 425-34. doi 10.7326/M151840. Epub 2016 Jan 19.

25. Hayward G, Thompson MJ, Perera R, Glasziou PP, Del Mar CB, Heneghan CJ. (2012, Oct 17). Corticosteroids as standalone or addon treatment for sore throat. Cochrane Database Syst Rev. 10: CD008268. doi 10.1002/14651858.CD008268.pub2.

26. Hayward GN, Hay AD, Moore MV, Jawad S, Williams N, Voysey M, Cook J, Allen J, Thompson M, Little P, Perera R, Wolstenholme J, Harman K, Heneghan C. (2017, Apr 18). Effect of Oral Dexamethasone Without Immediate Antibiotics vs Placebo on Acute Sore Throat in Adults: A Randomized Clinical Trial. JAMA. 317(15): 1535-1543. doi 10.1001/jama.2017.3417.

27. Karpathios T, Drakonaki S, Zervoudaki A, Coupari G, Fretzayas A, Kremastinos J, Thomaidis T. (1992, Nov). Arcanobacterium haemolyticum in children with presumed streptococcal pharyngotonsillitis or scarlet fever. J Pediatr. 121; 5 Pt 1:735-7.

28. Little P, Stuart B, Hobbs FD, Butler CC et al. (2013, Nov 25). DESCARTE investigators. Predictors of suppurative complications for acute sore 
throat in primary care: prospective clinical cohort study. BMJ. 347: f6867. doi 10.1136/bmj.f6867.

29. Little P, Williamson I, Warner G, Gould C, Gantley M, Kinmonth AL. (1997, Mar 8). Open randomised trial of prescribing strategies in managing sore throat. BMJ. 314(7082): 722-7.

30. Madanick RD. (2014, Mar). Extraesophageal presentations of GERD: where is the science? Gastroenterol Clin North Am. 43(1): 105-20. doi 10.1016/j.gtc.2013.11.007. Epub 2013 Dec 28.

31. Marchello C, Ebell MH. (2016, Nov). Prevalence of Group C Streptococcus and Fusobacterium Necrophorum in Patients With Sore Throat: A Meta-Analysis. Ann Fam Med. 14(6): 567-574. doi 10.1370/afm.2005.

32. Olympia RP, Khine H, Avner JR. (2005, Mar). Effectiveness of oral dexamethasone in the treatment of moderate to severe pharyngitis in children. Arch Pediatr Adolesc Med 159(3): 278-82.

33. Pan J et al. (2011). Efficacy and safety of recombinant human lysozyme spray in treatment of pharyngitis and tonsillitis evaluated by multicenter, randomized, double-blind,multi-dose, parallel controlled trial. International journal of respiration. $31 ; 12$. doi $10.3760 /$ cma.j.issn. 1673-436X.2011.012.003.

34. Paul SP, Heaton PA. (2014, Apr). At a glance: scarlet fever in children. J Fam Health Care. 24(3): 25-7.

35. Richardson M, Elliman D, Maguire H, Simpson J, Nicoll A (2001, Apr). Evidence base of incubation periods, periods of infectiousness and exclusion policies for the control of communi- cable diseases in schools and preschools. Pediatr Infect Dis J. 20(4): 380-91.

36. Shulman ST, Bisno AL, Clegg HW, Gerber MA, Kaplan EL, Lee G, Martin JM, Van Beneden C. (2012, Nov 15). Infectious Diseases Society of America. Clinical practice guideline for the diagnosis and management of group A streptococcal pharyngitis: 2012 update by the Infectious Diseases Society of America. Clin Infect Dis. 55(10): e86-102. doi 10.1093/cid/cis629. Epub 2012 Sep 9.

37. Soon GS, Laxer RM. (2017, Oct). Approach to recurrent fever in childhood. Can Fam Physician. 63(10): 756-762.

38. Spinks A, Glasziou PP, Del Mar CB. (2013, Nov 5). Antibiotics for sore throat. Cochrane Database Syst Rev. (11): CD000023. doi 10.1002/14651858.CD000023.pub4.

39. Thompson M, Vodicka TA, Blair PS, Buckley DI, Heneghan C, Hay AD. (2013, Dec 11). TARGET Programme Team. Duration of symptoms of respiratory tract infections in children: systematic review. BMJ. 347: f7027. doi 10.1136/bmj.f7027.

40. Tiemstra J, Miranda RL. (2009, Nov-Dec). Role of non-group a streptococci in acute pharyngitis. J Am Board Fam Med. 22(6): 663-9. doi 10.3122/jabfm.2009.06.090035.

41. Wang YB, Germaine GR. (1991). Effect of Lysozyme on glucose fermentation, cytoplasmic $\mathrm{pH}$, and intracellular potassium concentrations in Streptococcus multans. Infect Immun. 59: 638-44.

42. Workowski KA, Bolan GA; Centers for Disease Control and Prevention. (2015, Jun 5). Sexually transmitted diseases treatment guidelines, 2015. MMWR Recomm Rep. 64(RR-03): 1-137.

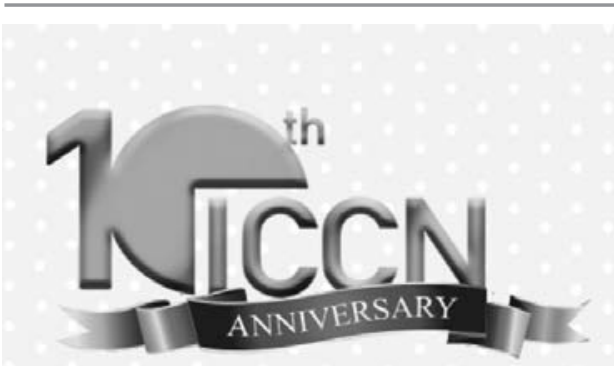

INTERNATIONAL CONFERENCE ON CLINICAL NEONATOLOGY

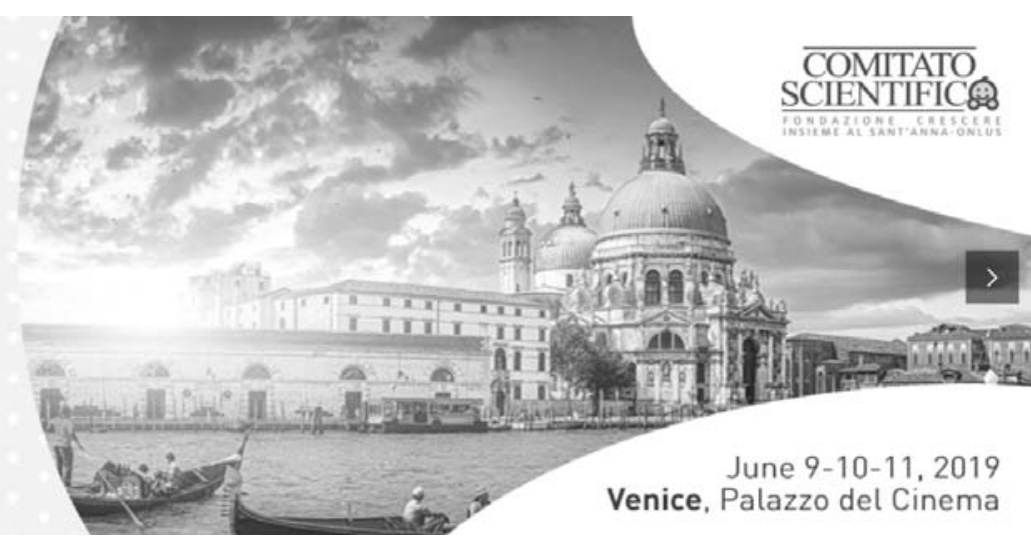

Main topics:

- Hypothermia in preterms: what's new?

- Teamworking in the NICU

- EPO and neuroprotection: an update

- NIDCAP and family-centered care

- Delivery of fetal CHD patients

\section{GOOD REASONS TO ATTEND THIS CONGRESS}

- 10th anniversary celebration - a unique occasion to attend free of charge

- A comprehensive program with the hottest news in neonatology

- An excursus on past 10 years achievements

- Venice - the only place to be in June

- Top science lectures accessible to everyone

More information: https://www.mcascientificevents.eu/iccn/ 


\section{АЬВІВСЬКИӢ МЕАИЧНИЙ ФОРУМ}

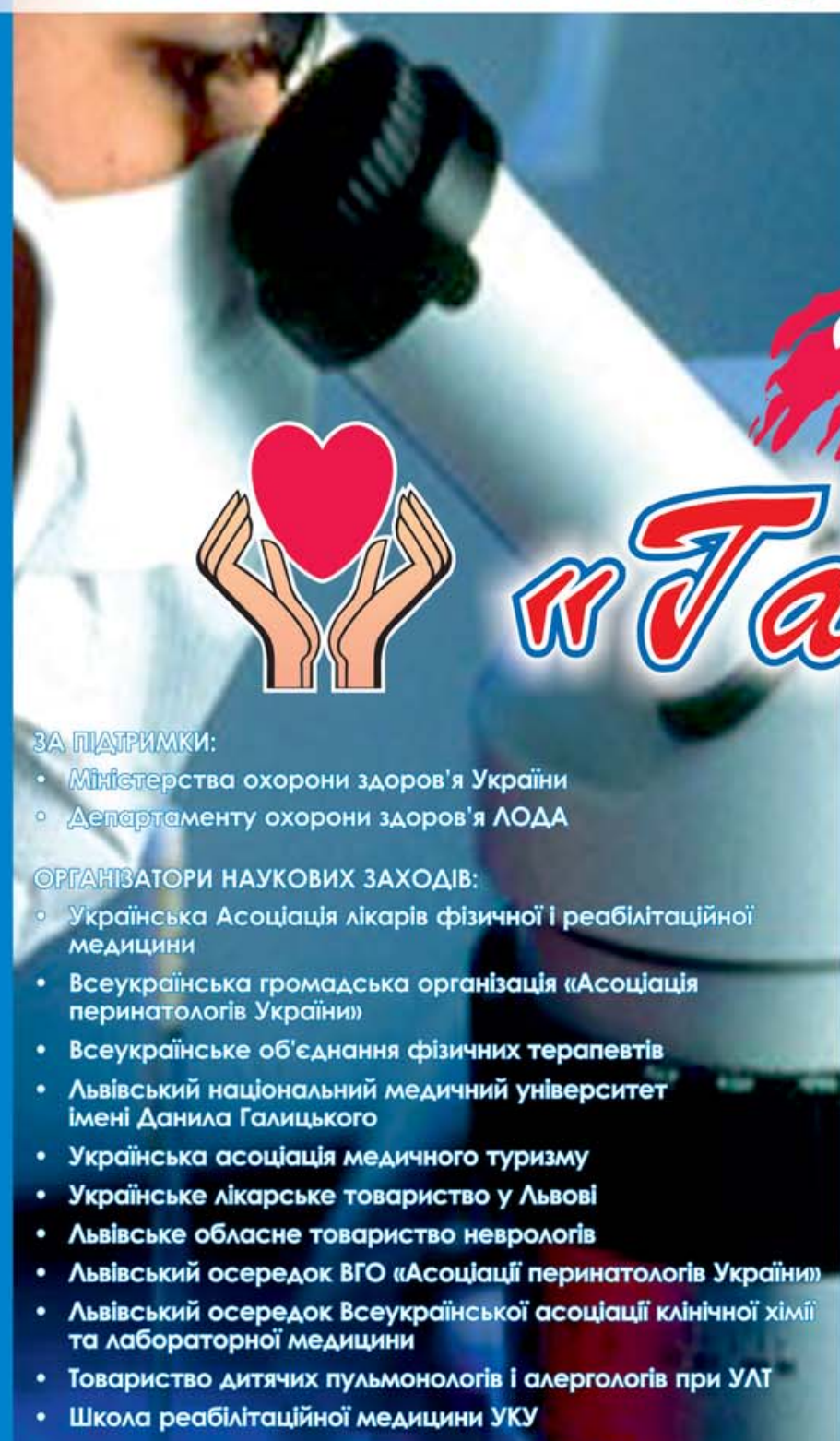

р. ПАРТНЕР ФОРУМУ:

ПАРТНЕР ВИСТАВКИ:
Інформаційні партнери: $\quad$ ЗДоров'я' УКраїни $\mathrm{Nt=}$

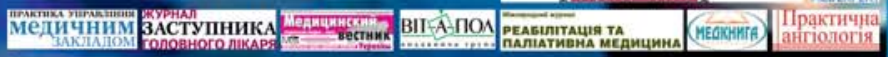

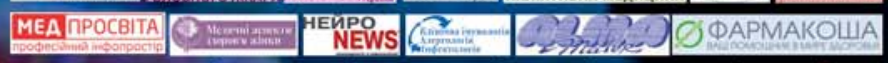

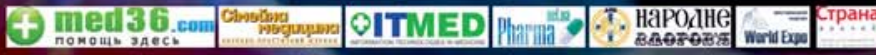

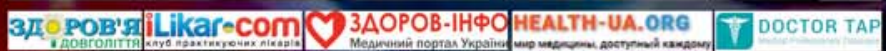

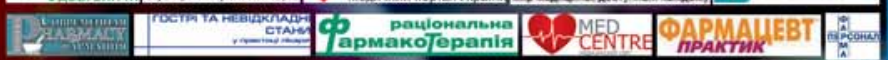

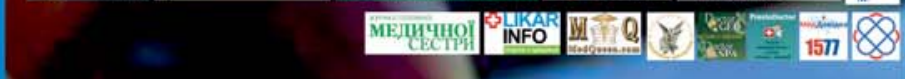

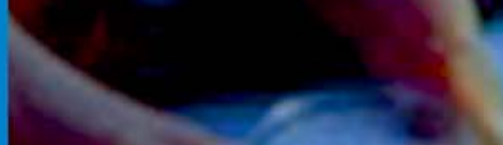

OPГАНІЗАТОР ФОРУMY:
TAM-IKCII $0^{\circ}$ AKLIOHEPHE TOBAPИCTBO те^.: (032) 2971369,2970628 09-11 kijmня

ПАМАЦ МИСТЕЦТВ (вул.Коперника, 17)

\section{МЕАИЧНА ВИСТАВКА}

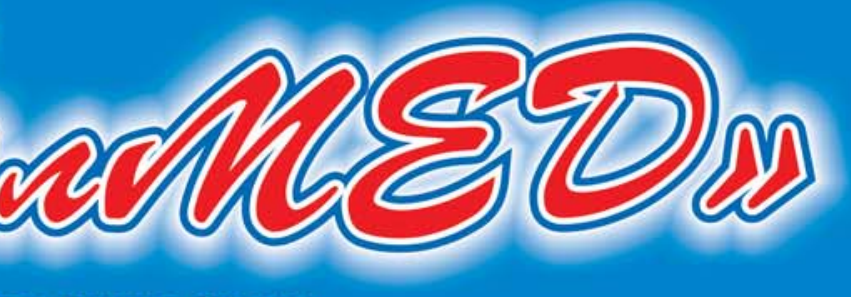

ТЕМАТИЧНІ РОЗАІАИ:

- Аікувальне, Аіагностичне та реабілітаційне облалнання;

- МеАичні прилаАи та інструменти;

- ^абораторна меАицина;

- Засоби реабіАітації та товари А^я АюАей 3 обмеженими можАивостями;

- Засоби НаАवнНя НЕВіАКАवАНОї АОПОМОГИ;

- Офттаьмологічні послуги та облаАнання, оптика та окуляри;

- Організація та оснащення меаичних заклааів;

- Фармацевтичні препарати;

- Сучасна каініка та посаути;

- МеАичний оАяг, засоби санітарії та Аезінфекції;

- Страхова меаицина;

- Біологічно активні Аобавки, фіто-проАукти та лікувальна косметика

В рамках виставки:

- V спеціалізована експозиція «МеАичний туризм»

- V спеціалізована експозиція "Реабікітація"

Наукові захоАи Форуму:

09 квітня Науково-практична конференція «Актуальні питання неврології. Сучасні алгоритми Аіагностики та Аікування"

10 квітня Науково-практична конференція «Сучасні аспекти фізичної та реабілітаційної меАицинил

10 квітня Науково-практична конференція «^абораторна МеАицина в світАі реформування системи охорони зАоров'яा)

10 квітня Семінар

«Аискусійні питання Аитячої пу^ьмоно^огіï та а^ерго^огіi. Аналіз клінічних випаАків"

11 квітня Науково-практична конференція «Проблеми репроАуктивного зАоров'я сім'i)

11 квітня Практичний майстер-к^ас по новітнім технологіям в галузі реабілітації

www.galexpo.com.ua/galmed www.facebook.com/Lviv.Medical.Forum/ 


\section{Правила подачи иоформлениястатей}

Авторская статья направляется в редакцию по электронной почте в формате MS Word. Статья сопровождается официальным направлением от учреждения, в котором была выполнена работа, с визой руководства (научного руководителя), заверенной круглой печатью учреждения, экспертным заключением о возможности публикации в открытой печати, заключением этического комитета учреждения или национальной комиссией по биоэтике. На последней странице статьи должны быть собственноручные подписи всех авторов и информация о процентном вкладе в работу каждого из авторов. Принимаются оригиналы сопроводительных документов с приложением печатного экземпляра рукописи, подписанного автором(ами), официального направления, присланные по почте, или сканированные копии вышеприведенных документов и первой (титульной) страницы статьи с подписью всех авторов статьи в формате Adobe Acrobat (*.pdf), присланные на электронный адрес редакции.

Статьи принимаются на украинском, русском или английском языках.

Структура материала: введение (состояние проблемы по данным литературы не более 5-7-летней давности); цель, задачи, материалы и методы; результаты исследований и их обсуждение (освещение статистически обработанных результатов исследования); выводы; перспективы дальнейших исследований в данном направлении; список литературы (два варианта), рефераты на русском, украинском и английском языках.

Реферат является независимым от статьи источником информации, кратким и последовательным изложением материала публикации по основным разделам и должен быть понятен без самой публикации. Его объем не должен превышать 200-250 слов. Обязательно указываются ключевые слова (от 3 до 8 слов) в порядке значимости, способствующие индексированию статьи в информационно-поисковых системах.

Реферат к оригинальной статье должен быть структурированным и повторять структуру статьи: цель исследования; материалы и методы; результаты; выводы; ключевые слова. Все разделы в реферате должны быть выделены в тексте жирным шрифтом.

Для остальных статей (обзор, лекции, клинический случай и др.) реферат должен включать краткое изложение основной концепции статьи и ключевые слова.

На первой странице указываются: индекс УДК слева, инициалы и фамилии авторов, название статьи, название учреждения, где работают авторы, город, страна

При проведении исследований с привлечением любых материалов человеческого происхождения в разделе «Материалы и методы» авторы должны указывать, что исследования проводились в соответствии со стандартами биоэтики, были одобрены этическим комитетом учреждения или национальной комиссией по биоэтике. То же самое относится и к исследованиям с участием лабораторных животных.

Например: «Исследование было выполнено в соответствии с принципами Хельсинской Декларации. Протокол исследования был одобрен Локальным этическим комитетом (ЛЭК) для всех участвующих».

«При проведении экспериментов с лабораторными животными все биоэтические нормы и рекомендации были соблюдены».

Количество иллюстраций (рисунки, схемы, диаграммы) должно быть минимальным. Иллюстрации (диаграммы, графики, схемы) строятся в программах Word или Excel; фотографии должны быть сохранены в одном из следующих форматов: PDF, TIFF, PSD, EPS, AI, CDR, QXD, INDD, JPG (300 dpi).

Таблицы и рисунки помещают в текст статьи сразу после первого упоминания. В подписи к рисунку приводят его название, расшифровывают все условные обозначения (цифры, буквы, кривые и т.д.). Таблицы должны быть оформлены в соответствии с требованиями ГАК, компактными, пронумерованными, иметь название. Номера таблиц, их заголовки и цифровые данные, обработанные статистически, должны точно соответствовать приведенным в тексте.

Ссылки на литературные источники в тексте обозначаются цифрами в квадратных скобках, должны отвечать нумерации в списке литературы. Статьи со списком литературных источников в виде постраничных или концевых ссылок не принимаются.

Необходимо предоставлять два варианта списка литературы.

Первый вариант приводится сразу после текста статьи, источники располагаются по алфавиту (сначала работы, опубликованные на русском или украинском языках, далее - на других языках).

Второй вариант полностью повторяет первый, но источники на украинском и русском языках ПЕРЕВОДЯТСЯ! на английский язык. Он необходим для сайта, повішения индекса цитирования авторов и анализа статьи в международных наукометрических базах данных.

Оба варианта оформляются в соответствии со стилем APA (American Psychological Association style), используемым в диссертационных работах. Пример оформления для обоих вариантов:

Автор АA, Автор ВB, Автор СС. (2005). Название статьи. Название журнала. 10(2); 3: 49-53.

Автор АA, Автор ВВ, Автор СС. (2006). Название книги. Город: Издательство: 256.

В тексте статьи допускаются общепринятые сокращения, а также авторские сокращения, которые обязательно расшифровываются в тексте при первом упоминании и остаются неизменными по всему тексту.

В конце статьи авторы должны заявить о наличии каких-либо конкурирующих финансовых интересов в отношении написания статьи. Указание конфликта интересов в статье является обязательным.

Пример: «Авторы заявляют об отсутствии конфликта интересов» или «Материал подготовлен при поддержке компании...»

Статья заканчивается сведениями обо всех авторах. Указываются фамилия, имя, отчество (полностью), ученая степень, ученое звание, должность в учреждении/учреждениях, рабочий адрес с почтовым индексом, рабочий телефон и адрес электронной почты; идентификатор ORCID (https://orcid.org/register). Сокращения не допускаются. Автор, ответственный за связь с редакцией, указывает свой мобильный/контактный номер телефона.

Ответственность за достоверность и оригинальность поданных материалов (фактов, цитат, фамилий, имен, результатов исследований и т.д.) несут авторы.

Редакция обеспечивает рецензирование статей, выполняет специальное и литературное редактирование, оставляет за собой право сокращать объем статей. Отказ авторам в публикации статьи может осуществляться без объяснения его причин и не считается негативным заключением относительно научной и практической значимости работы.

Статьи, оформленные без соблюдения правил, не рассматриваются и не возвращаются авторам. 


\section{СИМ ЗАОРОВОГО ПОАИХУ}
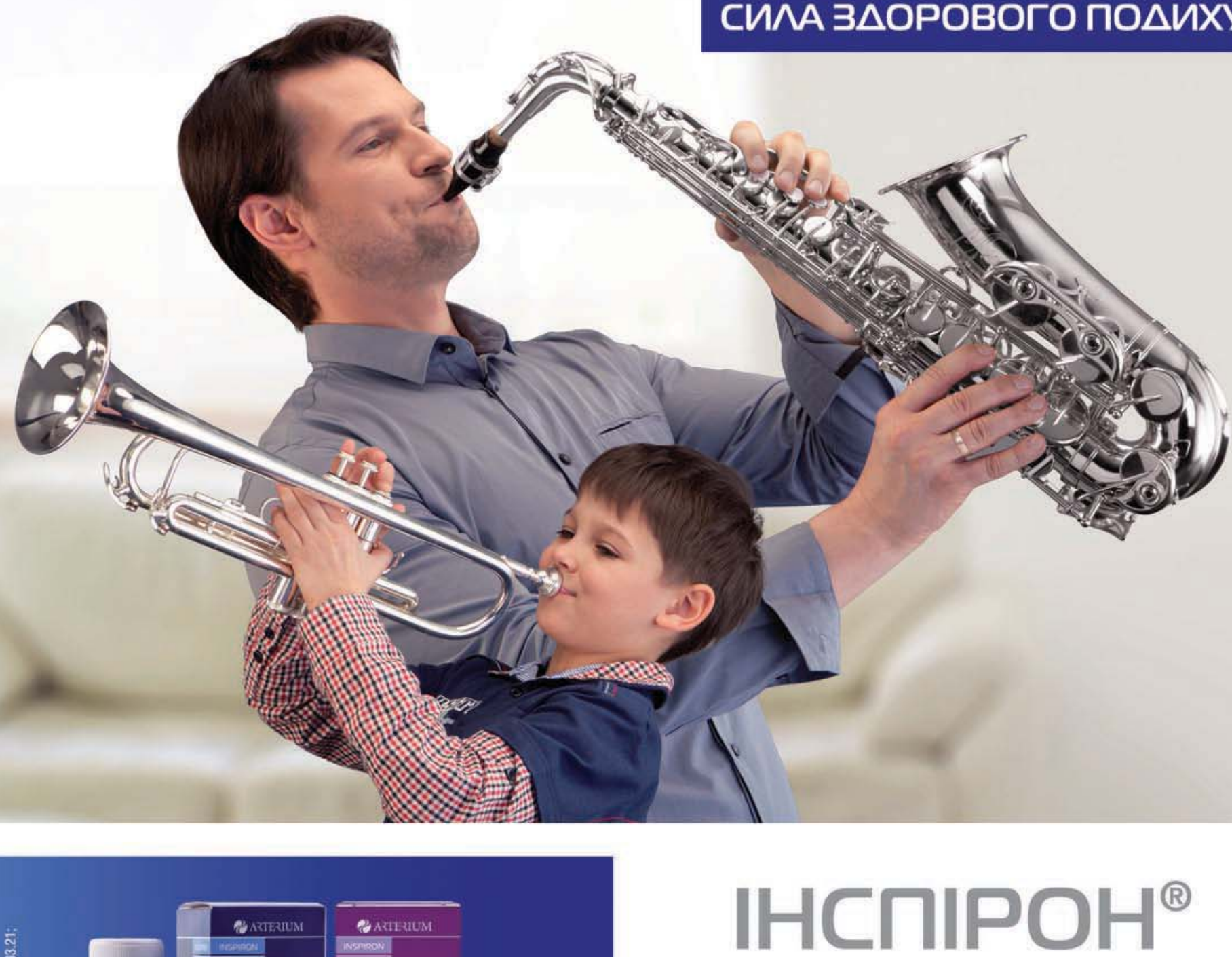

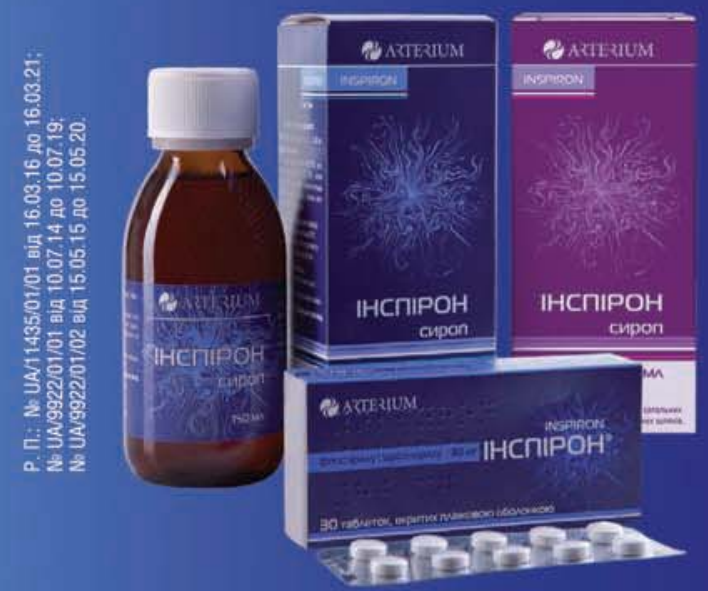

Інспірон ${ }^{\circledR}$ - перший генеричний фенспірид в Україні *

- цілеспрямована комплексна протизапальна дія по відношенню до дихальних шляхів

- дозволене застосування у дітей з 2-х років ${ }^{2}$

ВІДПУСКАЕТЬСЯ ЗА РЕЦЕПТОМ ЛІКАРЯ. Інформація виключно для медичних іфармацевтичних працівників. Для використання у просеесійній діяпьності.

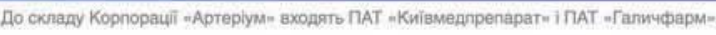

«Артеріум» Фармацевтична Корпорація

www.arterium.ua
Діюча речовина: фенспірид

1) ІнспіронФ, таблетки, вкриті плівковою оболонкою, по 80 мг: 1 таблетка містить фенспіриду гідрохлориду, у перерахуванні на 100\% речовину, 80 мг.

2) Інспірон ${ }^{\circ}$, сироп, 2 мг/мл: 1 мл сиропу містить фенспіриду гідрохлориду у перерахуванні на суху речовину 2 мr.

3) Інспірон॰ сироп, 4 мr/мл: 1 мл лікарського засобу містить фенспіриду гідрохлориду у перерахуванні на суху речовину 4 мг.

Фармакотерапевтична група. Засоби, що діють на респіраторну систему. Інші засоби для системного застосування при обструктивних захворюваннях дихальних шляхів. Код ATC R03D X03.

\section{Клінічні характеристики.}

Показання.

- Лікування гострих та хронічних запальних процесів ЛОР-органів та дихальних шляхів, у складі комплексної терапії бронхіальної астми.

- Сезонний та цілорічний алергічний риніт та інші прояви алергії з боку респіраторної системи та ЛОР-органів.

- Респіраторні прояви кору, грипу.

- Симптоматичне лікування коклюшу.

Протипоказання.

Підвищена чутливість до фенспіриду гідрохлориду та/або до інших компонентів препарату.

Побічні реакцї.

Помірна тахікардія, розлади травлення, нудота, біль у шлунку, діарея, блювання, еритема, висип, кропив'янка, свербіж, сонливість, астенія та ін.

Фармакологічні властивості.

Проявляє антибронхоконстрикторні та протизапальні властивості, зумовлені взаємодією кількох взаємопов'язаних механізмів:

- блокує H1-гістамінові рецептори та чинить спазмолітичну дію на гладку мускулатуру бронхів:

- чинить протизапальну дію;

- інгібує а1-адренорецептори, які стимулюють секрецію в'язкого слизу.

Дітям препарат застосовують тільки 3 2-х років і у вигляді сиропу.

' на підставі Інструхшій для медичного застосування пікарських засобів Інспірон, таблетки, вкриті пnівковою

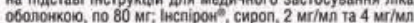

?. Diтrм препарат застосовуоть тільки у вигляді сиропу.

Iнформашію наведено в скороченому вигляді, повна інформація викладена в Інструхціях для медичного застосування

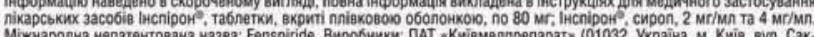

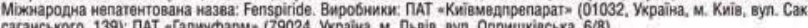
Дата останньього перегляду інформацйнного матеріапу. 12.12.2018 


\section{ЛІСОБАКТ ${ }^{\circledR}$}

s

с АЛЛЯ дорослих

I ДIТЕЙ

$\longrightarrow, 0^{2}$ ! Мама всім нам Лісобакт ${ }^{\circledR}$ куnує!

$\Delta, 0,8 \geqslant$

$\operatorname{mos}$

( )

[3

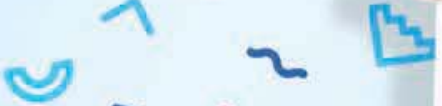

† 30 льодяників

\section{ЛІСОБАКТ ${ }^{\oplus}$}

S

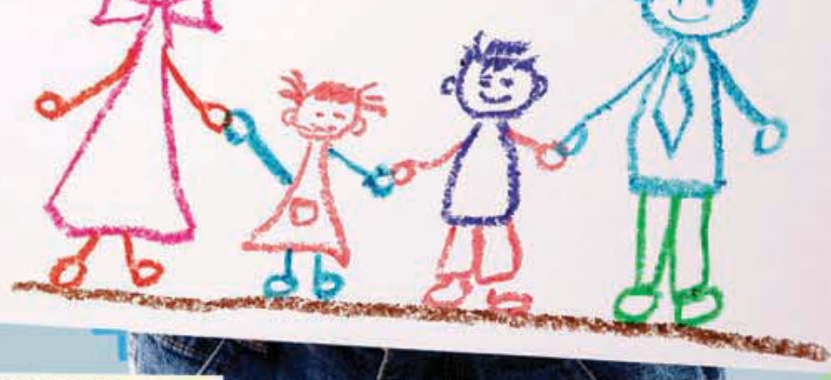

\section{ᄀ7iner}

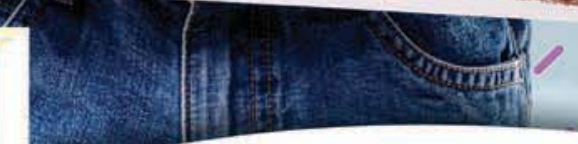

(D) BО5NALUEK

Малюку і тату горло лікувати!

(5) Усуває запалення та біль у горлі

(5) Широкий спектр дії: віруси, бактерії, гриби

(5) Підвищує місцевий захист організму

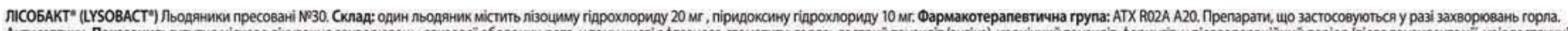

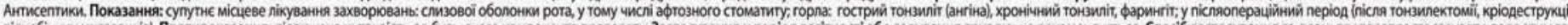

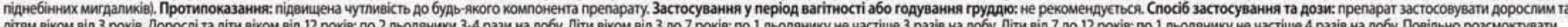

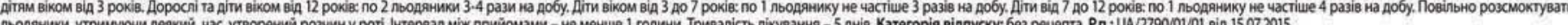
Виробник: Босналек д.д//Bosnalijek d.d. Перед призначенням та застосуванням необхідно ознайомитись з інструкцікю по використанніо, яка додаеться до лікарського засобу. 